\title{
BALNEO RESEARCH JOURNAL
}

Vol 10 No. 3, September 2019
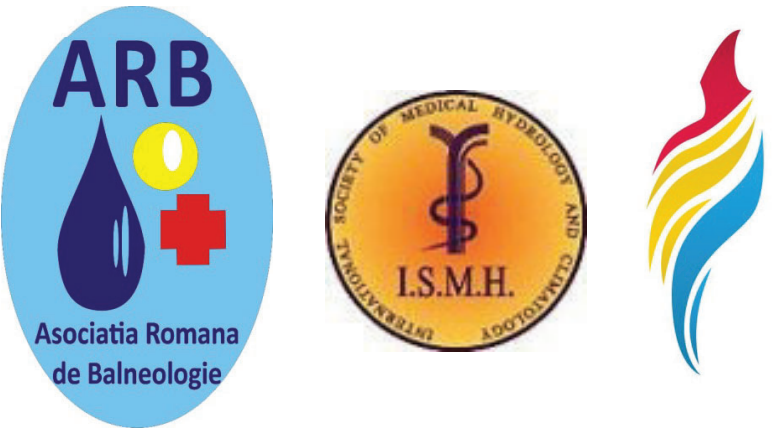

Congress Abstracts

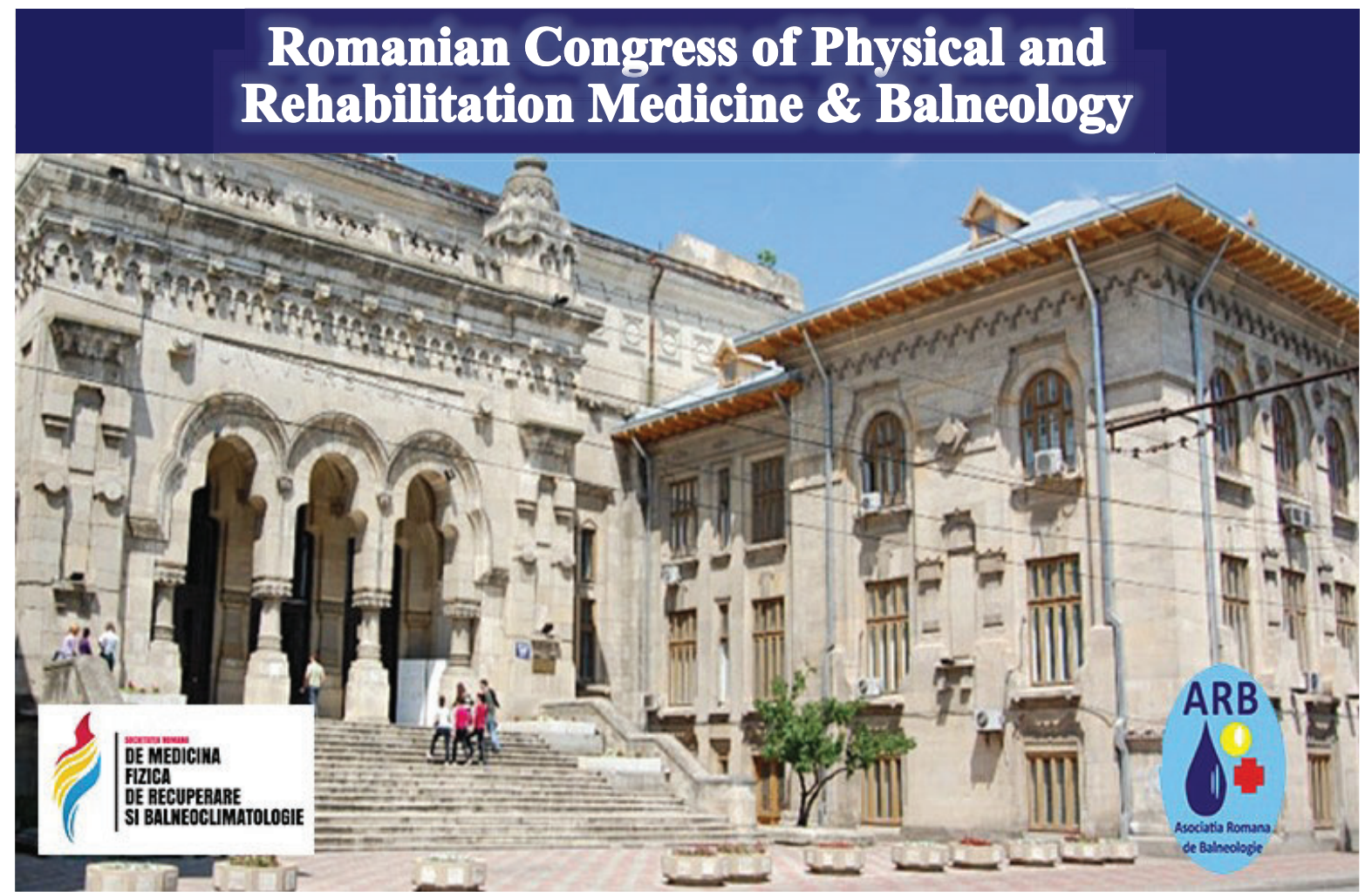

03-06 September 2019, Galați

\section{$\frac{\text { BALNEO }}{\text { KESERCH }}$ BALNEO RESEARCH JOURNAL English Edition \\ EISSN 2069-7619 PISSN 2069-7597 ROMANIAN ASSOCIATION OF BALNEOIOGY}

Editors: MUNTEANU Constantin, Romanian Association of Balneology (Bucharest)

DOGARU GABRIELA, Romanian Association of Balneology (Cluj Branch)

Website http://bioclima.ro/Journal.htm

E-mail: office@bioclima.ro

ISSN: 2069-7597 / elSSN: 2069-7619

Balneo Research Journal is part of the international data bases (BDI) as follow: EBSCOhost. CrossRef, DOAJ, Electronic Journals Library (GIGA), USA National Library of Medicine - NLM, Emerging Sources Citation Index- ESCI (Thomson Reuters)

Publisher: Romanian Association of Balneology (Bucharest)

Asociatia Romana de Balneologie / Romanian Association of Balneology 


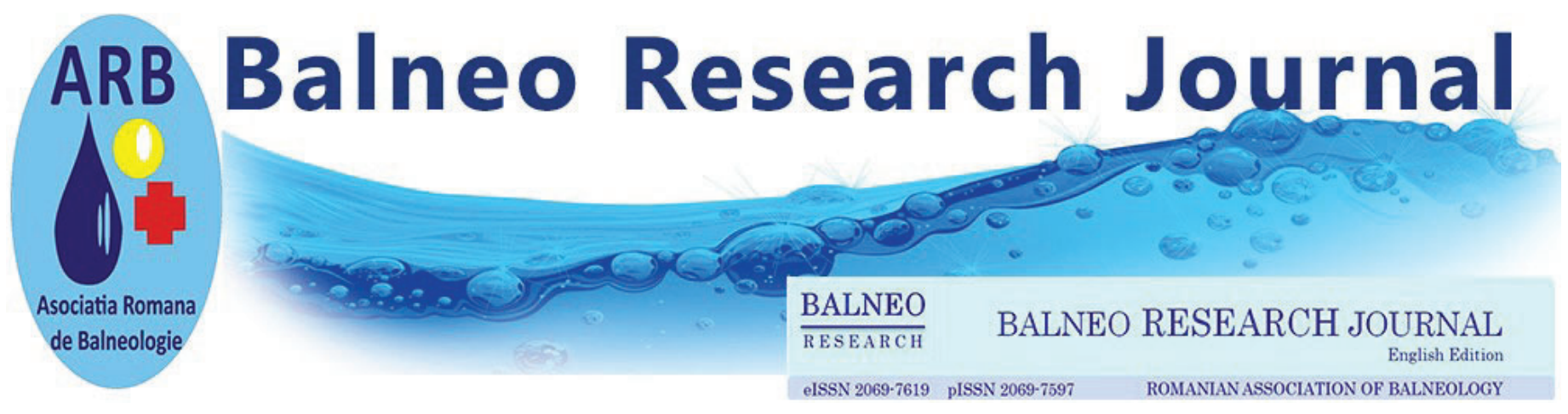

- International title: Balneo Research Journal / Index name: BALNEO

- Publisher: Romanian Association of Balneology / Asociația Română de Balneologie

- $\quad$ Aleea Dobrina, No.7, BI. D10, Ap.4, District 2, Bucharest, Romania / Mobil 004/0723.138.339 /

- Email : office@bioclima.ro

- Aims and scope: Balneo Research Journal provides a platform to disseminate scientific knowledge to researchers, physicians and other authors interested in publishing scientific articles in the field of Physical and Rehabilitation Medicine and Balneology, in a multidisciplinary scientific journal with peer-review group, open-access, which presents many aspects of daily spa research, medicine, medical tourism and natural therapeutic factors. All the articles are published also online. The journal aims to be a source of complete and modern scientific information for spa sector. Emphasis will be placed on the rapid and transparent publication of scientific articles of interest for balneology, which will be stored in international databases.

- ISSN: 2069-7597 / elSSN: 2069-7619

- Frequency: 4 issues per year, plus addenda

- The language of publication: English

- License:

$$
\text { (cc) BY-NC-ND }
$$

\section{Website http://bioclima.ro/Journal.htm}

Online submission link:

\section{Submit}

Ofline submission by email: articleonbrj@bioclima.ro

Balneo Research Journal was recognized by the Romanian College of Physicians for 10 CME credits, based on yearly subscription - Recognition Letter for 2019

Balneo Reserch Journal on Scholar Google

- Journal Field: Medicine - Therapeutics. Pharmacology

- Journal Discipline: Rehabilitation, Physical Medicine and Balneology

- Article Publication Charges: 100 Euro per admitted for publication article, starting from the next issue: NEXT: Vol 10 No. 1, February 2019

- Payment tools for publication charges:

PayPal: Bank transfer: IBAN RO92RNCB0067118770120001, Bank: BCR -

Sucursala Dr. Felix, C.I.F. 27579487,

- Editorial Team can invite between 3 and 5 authors per issue for publishing in Balneo Research Journal free of charge.

For submmiting articles for Balneo Research Journal, authors must use the following template: Balneo Template

- The Peer Review process is single blind (editors choose the peer reviewers and send them the article and discuss the needed changes)

Peer review article evaluation form -

- The journal's presence in various indexing services, directories and listings: At the present moment, Balneo Research Journal is part of the international data bases (BDI) as follow:

EBSCOhost

CrossRef

DOAJ

Electronic Journals Library (GIGA)

National Library of Medicine - NLM

Emerging Sources Citation Index (ESCI) - science.thomsonreuters.com 


\section{Honorary Presidents:}

Prof. Univ. Dr. Puiu Lucian Georgescu - President of the University Senate "Dunărea de Jos" from Galați

Academician Constantin Ionescu-Târgoviște - Romanian Medical Association President

Prof. Univ. Dr. Gelu Onose - UMF Carol Davila Bucuresti, Honorary President of SRMFRB

Scientific Committee Honorary President:

Prof. Univ. Dr. Zeki Karagulle - ISMH Past President

Congress Presidents:

Prof. Univ. Dr. Aurel Nechita - Galați Physicians College President Dr. Biol. Constantin Munteanu, Romanian Association of Balneology (ARB) President

Conf. Dr. Dan Blendea, President of Romanian Society of Physical Medicine, Rehabilitation and Balneoclimatology

Scientific Commitee

President: Prof. Dr. Liviu Lazăr

Vice-Presidents:

Conf. Dr. Olga Surdu

Conf. Dr. Aurelia Romila

Sef Lucrari Dr. Gabriela Dogaru

Sef Lucrari Dr. Ioana Stanescu

Sef Lucrari Dr. Elena Valentina Ionescu

Sef Lucrari Dr. Mihaiela Chicu

Members:

Sef Lucrari Dr. Silișteanu Sînziana Călina

Sef Lucrari Dr. Cristina Daia

Sef Lucrari Dr. Andrada Mirea

Dr. Cristina Popescu

Dr. loana Andone

Dr. Simona Carniciu

Dr. Doroteea Teoibaș Șerban

Dr. Carmen Firan

Dr. Liliana Stanciu

As. Univ. Dr. Doinița Oprea

As. Univ. Dr. Simona Stoica

Organizing Committee

President Conf. Dr. Liliana Pădure

Vice-Presidents:

Șef Lucrări Mădălina Codruța Verenca

Conf.Dr. Camelia Ciobotaru

Dr. Bioch. Mihail Hoteteu

Dr. Aura Spînu

Members:

Dr. Mariana Varodi

Dr. Liviu lordache

Dr. Daniela Pop

Conf. Dr. Calin Corciova

Conf. Dr. Dr. Mariana Rotariu

Dr. Marius Turnea

Camil Filimon

\section{Thematic Areas}

\section{Balneology - Natural Therapeutic Factors}

* Mineral waters - food and therapeutic factor

* Peloids

* Climate

* Thalassa

* Gases (Mofettes, Solphatares)

* Salt mines and caves

\section{Healthy Lifestyle}

Healthy ageing

Balneoclimatology, Fitness and Wellness

\section{Ethical and Legal issues}

Public Health and Health Management / in RMFB

Balneo Tourism Destinations Marketing

Physical and Rehabilitation Medicine in:

* Neurological \& Communicational pathology

* Musculoskeletal pathology

* Pediatric pathology

* Geriatric pathology

* Respiratory pathology

* Cardiovascular pathology

Physio - / Kinesiotherapy

Mechatronic / Robotic interventions for medical rehabilitation Holistic Integrative Interventions

Education and Scientific Research

Miscellaneous 


\section{General Program}

\section{Tuesday - 03 September 2019}

10.00 -16.00 - Registration of participants, Visit - Museum of the Episcopal Palace in Galați

- Reception of the official delegates, the Episcopal Palace in Galați

16.00 - 16.45 Extraordinary General Assembly of SRMFRB

17.00 -19.00 - The opening ceremony of the Congress - Garden of the Episcopal Palace in Galați

19.00 Welcome Networking Cocktail, Galați Episcopal Palace

\section{Wednesday - 04 September 2019}

The room for the scientific work will be at the Botanical Garden in Galați

09.00 -11.00 - Scientific Plenary Session Plenary Session

$11.00-11.30$ - Pause - Symposium satellite of the industry of profile

11.30 - 11.45 - Coffee / tea break

11,45 -13,45 - Scientific Session II

13.45 - 15.00 - Lunch break

$15.00-17.00$ - Scientific Session III

17.00 -17.30 Poster Session I

17.15 - 18.00 Extraordinary General Assembly of RoSNeRa

18.00 - 18.45 Extraordinary General Assembly of RoSCoS

20,00 Dinner

\section{Thursday- 05 September 2019}

The room for the scientific work will be at the Botanical Garden in Galați

09.00 -11.00 - Scientific Session IV

11.00 -11.30 - Pause - Symposium satellite of the industry of profile

11.30 - 11.45 - Coffee / tea break

11.45 -13.45 - World Spinal Cord Injury Day - Session dedicated to International Spinal Cord Injury Day

13.45 -15.00 - Lunch break

15.00 -17.00 - Scientific Session VI

17.00 -17.45 Poster Session II

17.15 - 18.00 Extraordinary General Assembly of RoSNeRa - continuation or recall

18.00 - 18.45 Extraordinary General Assembly of RoSCoS - continuation or recall

20,00 Gala Dinner

\section{Friday-06 September 2019}

The room for the scientific work will be at Sărat Lake, in the room offered by the Archdiocese of the Lower Danube in Galați

8.00 - 9.30 Travel to Salt Lake

$09.30-11.30$ - Scientific Session VII

$11,30-11,45$ - Pause - Symposium satellite of the industry of profile

11.45 - 12.00 - Coffee / tea break

$12.00-14.00$ Scientific Session VIII

14.00 - 15.00 - Lunch break

15.00 -17.00 - Scientific Session IX

17.00 - 17.45 Extraordinary General Assembly of the Romanian Association of Balneology (ARB)

17.45 - 18.30 Extraordinary General Assembly of SRMFRB - continuation or recall

20.00 Dinner

\section{Saturday - Sunday (07-08 September 2019): Social program}

- Danube Delta Excursion - Departure by bus from Galați to Tulcea Saturday 7 September, 8.00 am Accommodation one night in Tulcea, Hotel Esplanada. The program includes lunch (Mila 23) and dinner (Hotel Esplanada) on September 7, boat ride on the Danube - visit to the Danube Delta. 


\section{Scientific Program}

Wednesday - 04 September 2019- Botanical Garden of Galați

09,00 -11,00 - Scientific session I- Plenary Session

Chairmen: Zeki KARAGÜLLE, Umberto SOLIMENE, Gelu ONOSE, Constantin MUNTEANU, Olga SURDU

\begin{tabular}{|c|c|c|}
\hline Authors & Title & Abstract \\
\hline $\begin{array}{l}\text { CONSTANTIN MUNTEANU, } \\
\text { Mihail HOTETEU, Diana MUNTEANU, } \\
\text { Gabriela DOGARU - } 12 \text { minutes }\end{array}$ & $\begin{array}{l}\text { PERSPECTIVES OF BALNEOLOGY } \\
* \quad \text { INTERNATIONAL DATA INPUTS, } \\
* \quad \text { NATIONAL OUTPUTS }\end{array}$ & L1 \\
\hline $\begin{array}{l}\text { UMBERTO SOLIMENE } \\
-14 \text { minutes }\end{array}$ & $\begin{array}{l}\text { CLIMATE AND HEALTH: A NEW CHALLENGE } \\
\text { FOR AN OLD SCIENCE }\end{array}$ & L2 \\
\hline $\begin{array}{l}\text { Zeki KARAGÜLLE } \\
-14 \text { minutes }\end{array}$ & $\begin{array}{l}\text { BALNEOLOGICAL TREATMENTS WITH NATURAL } \\
\text { HYDROGEN SULFIDE }\left(\mathrm{H}_{2} \mathrm{~S}\right) \text { WATERS }\end{array}$ & L3 \\
\hline $\begin{array}{l}\text { Constantin Florin Dragan, } \\
\text { Liliana Padure, } \\
\text { Gelu Onose } \\
\text { - } 12 \text { minutes }\end{array}$ & $\begin{array}{l}\text { SPECIFIC ADVANCED QUANTIFICATIONS ON THE } \\
\text { RELATIONSHIP BETWEEN THE ANGULATION OF THE } \\
\text { MAIN SCOLIOTIC CURVE AND LEG SWING IN THE } \\
\text { GAIT PHASES, IN CHILDREN AND ADOLESCENTS } \\
\text { WITH AND WITHOUT POSTURAL TREATMENT }\end{array}$ & L4 \\
\hline $\begin{array}{l}\text { Irina ALBADI, Camelia CIOBOTARU, } \\
\text { Andreea-Alexandra LUPU, } \\
\text { Ionela BALASA, Claudiu FATU, } \\
\text { Enghin SACHIR, } \\
\text { Gelu ONOSE - } 12 \text { minutes }\end{array}$ & $\begin{array}{l}\text { A MULTIMODAL APPROACHES TO MANAGE } \\
\text { REHABILITATION THERAPY OF DISFUNCTIONALS } \\
\text { ASPECTS TO A PACIENT WITH GOUT, MIELLITUS } \\
\text { DIABETES, ATRIAL FIBRILATION AND MIDDLE } \\
\text { CEREBRAL ARTERY STROKE }\end{array}$ & L5 \\
\hline $\begin{array}{l}\text { ELENA RAEVSCHI } \\
-12 \text { minutes }\end{array}$ & $\begin{array}{l}\text { PREVENTION CONSIDERATIONS IN } \\
\text { CARDIOVASCULAR DISEASES REGARDING THE } \\
\text { PREMATURE MORTALITY REDUCTION }\end{array}$ & L6 \\
\hline $\begin{array}{l}\text { ANIȘOARA CIMIL } \\
-12 \text { minutes }\end{array}$ & $\begin{array}{l}\text { THE EFFECTIVENESS OF THE REHABILITATION PRO- } \\
\text { GRAMME ACCORDING TO THE ETIOPATHOGENESIS } \\
\text { OF PROSTHETIC JOINT PATHOLOGY }\end{array}$ & L7 \\
\hline $\begin{array}{l}\text { TRAIAN -VIRGILIU SURDU, } \\
\text { Monica SURDU, Olga SURDU } \\
\text { - } 10 \text { minutes }\end{array}$ & $\begin{array}{l}\text { FOURTH INDUSTRIAL REVOLUTION (INDUSTRY 4.0) } \\
\text { AND MODERN THERMAL MEDICINE (THERME 4.0) } \\
\text { IN XXIST CENTURY }\end{array}$ & L8 \\
\hline $\begin{array}{l}\text { Gabriela DOGARU, } \\
\text { Akos MOLNAR, } \\
\text { Marieta MOTRICALA - } 10 \text { minutes }\end{array}$ & $\begin{array}{l}\text { EFFECTS OF CARBONATED MINERAL WATER AND } \\
\text { MOFETTE IN BĂILE TUȘNAD IN EXPERIMENTALLY } \\
\text { INDUCED ISCHEMIC HEART DISEASE }\end{array}$ & L9 \\
\hline
\end{tabular}


Wednesday - 04 September 2019- Botanical Garden of Galați

$11,45-13,45$ - Scientific session II

Chairmen: Elena RAEVSCHI, Liliana PADURE, Cristina DAIA, Anișoara CIMIL

\begin{tabular}{|c|c|c|}
\hline Authors & Title & Abstract \\
\hline $\begin{array}{l}\text { Aurelian Anghelescu, } \\
\text { Valentin Deaconu, } \\
\text { Catalina Axente, } \\
\text { Elena Constantin, } \\
\text { Gelu Onose } \\
-12 \text { minutes }\end{array}$ & $\begin{array}{l}\text { THERAPEUTIC DIFFICULTIES IN A YOUNG } \\
\text { PATIENT WITH MULTIDRUG RESISTANT } \\
\text { EPILEPSY (NEEDING VAGAL NERVE ELECTROSTIMULATI- } \\
\text { ON), SEQUELAE AFTER CONGENITAL VASCULAR CEREBRAL } \\
\text { MALORMATION, WITH CHRONIC GAIT IMPAIRMENTS } \\
\text { AND RECENT TRAUMATIC BRAIN COMPLICATION }\end{array}$ & L10 \\
\hline $\begin{array}{l}\text { Luminița NIRLU, Alexandru G. } \\
\text { STAVRICĂ, Laura Georgiana Popes- } \\
\text { cu, Ana Carmen Albeșteanu, } \\
\text { Ali-Osman Saglam, } \\
\text { Gelu Onose - } 12 \text { minutes }\end{array}$ & $\begin{array}{l}\text { DIAGNOSTIC PARTICULARITIES AND MULTIMODAL THE- } \\
\text { RAPEUTIC AND REHABILITATION APPROACHES TO A COM- } \\
\text { PLEX CASE OF POST ISCHEMIC STROKE WITH DYSPHAGIA } \\
\text { AND DYSPHONIA, ASSOCIATING MILLARD-GUBLER AND } \\
\text { WALLENBERG SYNDROMES - CASE REPORT }\end{array}$ & L11 \\
\hline $\begin{array}{l}\text { Cristina Octaviana DAIA, } \\
\text { Croitoru Stefana, Mariana Axente, } \\
\text { Gelu ONOSE - } 14 \text { minutes }\end{array}$ & $\begin{array}{l}\text { IONTOPHORESIS AND LASER APPLICATIONS IN FACIAL } \\
\text { NERVE PALSY }\end{array}$ & L12 \\
\hline $\begin{array}{l}\text { Doina Maria MOLDOVAN, } \\
\text { Gabriela DOGARU - } 12 \text { minutes }\end{array}$ & $\begin{array}{l}\text { SPLINTING VERSUS SURGICAL TREATMENT IN MALLET } \\
\text { FINGER }\end{array}$ & L13 \\
\hline $\begin{array}{l}\text { Doina Maria MOLDOVAN', } \\
\text { Gabriela DOGARU - } 12 \text { minutes }\end{array}$ & $\begin{array}{l}\text { EARLY REHABILITATION IN PATIENT AFTER TREAT- } \\
\text { MENT FOR DISTAL RADIUS FRACTURE }\end{array}$ & L14 \\
\hline $\begin{array}{l}\text { Liliana PADURE, Raluca PETCU, } \\
\text { Anca Irina GRIGORIU } \\
\text { - } 12 \text { minutes }\end{array}$ & $\begin{array}{l}\text { THE IMPACT OF MULTIFACTORIAL GAIT ANALYSIS ON THE } \\
\text { DIAGNOSIS AND REHABILITATION OF CHILDREN WITH } \\
\text { WALKING DISORDERS }\end{array}$ & L15 \\
\hline $\begin{array}{l}\text { Valerica Creanga-Zarnescu, Ana- } \\
\text { Maria Fatu, Mihaela Lungu, } \\
\text { Violeta Sapira, Anamaria Ciubara - } \\
12 \text { minutes }\end{array}$ & $\begin{array}{l}\text { REHABILITATION POSSIBILITIES OF } \\
\text { APHASIC PATIENT }\end{array}$ & L16 \\
\hline $\begin{array}{l}\text { Cristina DAIA, Simona SCHEK, } \\
\text { Stefana CROITORU, Alina GHER- } \\
\text { GHICEANU, Gelu ONOSE - } 12 \text { minu- } \\
\text { tes }\end{array}$ & $\begin{array}{l}\text { FAVORABLE REHABILITATION RESULTS ON A PATIENT } \\
\text { WITH SEVERE LEFT HEMIPLEGIA AFTER AN INTRAPAREN- } \\
\text { CHYMAL HEMATOMA }\end{array}$ & L17 \\
\hline $\begin{array}{l}\text { Elena VIZITIU, } \\
\text { Mihai CONSTANTINESCU, } \\
\text { Sînziana Călina SILIȘTEANU } \\
\text { - } 12 \text { minutes }\end{array}$ & $\begin{array}{l}\text { THE ROLE OF THERAPEUTIC SWIMMING IN THE PROP- } \\
\text { HYLAXIS OF SCOLIOSIS IN THE "C" LEFT IN CHILDREN DU- } \\
\text { RING THE PREPUBERTAL PERIOD }\end{array}$ & L18 \\
\hline
\end{tabular}


Wednesday - 04 September 2019 - Botanical Garden of Galați

$15,00-17,00$ - Scientific session III

Chairmen: Ana Maria BUMBEA, Mariana Rotariu, loana ANDONE, Madalina VERENCA

\begin{tabular}{|c|c|c|}
\hline Authors & Title & Abstract \\
\hline $\begin{array}{l}\text { Alexandru G. STAVRICĂ, } \\
\text { Luminița Nirlu, } \\
\text { Laura Georgiana Popescu, } \\
\text { Ana Carmen Albeșteanu, } \\
\text { Gelu ONOSE } \\
\text { - } 12 \text { minutes }\end{array}$ & $\begin{array}{l}\text { DIAGNOSTIC AND THERAPEUTIC APPROACHES IN } \\
\text { REHABILITATION CORRELATED TO A CASE OF } \\
\text { TETRAPARESIS (WITH PREDOMINANCE OF PARA- } \\
\text { PARESIS) AFTER SEVERE CCT - BIFRONTO - BASAL } \\
\text { AND BITEMPORAL CONTUSION. }\end{array}$ & L19 \\
\hline $\begin{array}{l}\text { Ana Maria Bumbea, Otilia Rogoveanu, } \\
\text { Carmen,Albu Rodica Traistaru, Cata- } \\
\text { lin,Bostina, Bogdan Stefan Bumbea, } \\
\text { Roxana Dumitrascu, Borcan Madalina }\end{array}$ & $\begin{array}{l}\text { MANAGEMENT OF SPASTICITY IN } \\
\text { NEUROLOGICAL PATIENTS }\end{array}$ & $\mathrm{L} 20$ \\
\hline $\begin{array}{l}\text { Laura Georgiana Popescu, } \\
\text { Luminița Nirlu, } \\
\text { Ana Carmen Albeșteanu, } \\
\text { Ali Osman Saglam, } \\
\text { Gelu Onose } \\
\text { - } 12 \text { minutes }\end{array}$ & $\begin{array}{l}\text { PARTICULARITIES OF COMPLEX THERAPEUTICAL- } \\
\text { LY-REHABILITATIVE MANAGEMENT, STEPWISE, } \\
\text { IN A PATIENT WITH POST-CCT } \\
\text { PSYCHO-COGNITIVE IMPAIRMENT IN A LARGE } \\
\text { POLYTRAMATIC CONTEXT - CASE REPORT }\end{array}$ & L21 \\
\hline $\begin{array}{l}\text { Adrian MELNIC, } \\
\text { Oleg PASCAL } \\
\text { - } 12 \text { minutes }\end{array}$ & $\begin{array}{l}\text { DEVELOPING STRATEGIES TO ADDRESS } \\
\text { COMORBIDITY IN STROKE REHABILITATION. }\end{array}$ & L22 \\
\hline $\begin{array}{l}\text { Dorin-Gheorghe TRIFF, } \\
\text { Simona POP } \\
-12 \text { minutes }\end{array}$ & $\begin{array}{l}\text { MONOGENIC DISEASES WITH MUSCULO } \\
\text { ARTICULAR LAXITY. DIAGNOSTIC CRITERIA AND } \\
\text { PRINCIPLES OF RECOVERY THERAPY }\end{array}$ & L23 \\
\hline $\begin{array}{l}\text { Catalin Ionite, } \\
\text { Dragos Arotaritei, Mihai llea, Mariana } \\
\text { Rotariu - } 12 \text { minutes }\end{array}$ & $\begin{array}{l}\text { THE USE OF ELASTIC BANDS IN THE RECOVERY } \\
\text { OF ANKLE SPRAINS }\end{array}$ & L24 \\
\hline $\begin{array}{l}\text { Mariana Rotariu, Marius Turnea, } \\
\text { Calin Corciova, Catalin lonite } \\
-12 \text { minutes }\end{array}$ & $\begin{array}{l}\text { THE EFFECTS OF CUBE THERAPY IN THE RECOV- } \\
\text { ERY OF THE ARTHROSIS HAND IN } \\
\text { GERIATRICS }\end{array}$ & L25 \\
\hline $\begin{array}{l}\text { Cristian Ștefan LIUȘNEA } \\
\text { - } 12 \text { minutes }\end{array}$ & $\begin{array}{l}\text { FITNESS AND WELLNESS. CONCEPTUAL } \\
\text { DELIMITATIONS }\end{array}$ & L26 \\
\hline $\begin{array}{l}\text { Adriana LUPU } \\
-12 \text { minutes }\end{array}$ & $\begin{array}{l}\text { NSAID THERAPY OF MUSCULOSKELETAL PAINS } \\
\text { AND ITS PARTICULARITIES IN THE PATIENTS } \\
\text { SUFFERING FROM CARDIOVASCULAR } \\
\text { DISORDERS }\end{array}$ & L27 \\
\hline
\end{tabular}


Thursday- 05 September 2019 - Botanical Garden of Galați

09,00 -11,00 - Scientific session IV

Chairmen: Alexandru Vlad CIUREA, Aurelia ROMILA, Mihaiela CHICU

\begin{tabular}{|c|c|c|}
\hline Authors & Title & Abstract \\
\hline $\begin{array}{l}\text { Mihaela MANDU, } \\
\text { Cristinel Dumitru BADIU, } \\
\text { Raluca PETCU, } \\
\text { Cosmin OPREA, } \\
\text { Gelu ONOSE } \\
\text { - } 12 \text { minutes }\end{array}$ & $\begin{array}{l}\text { CLINICAL-EVOLUTIVE PARTICULARITIES AND A } \\
\text { MULTIMODAL THERAPEUTIC-REHABILITATIVE, } \\
\text { AS WELL AS THROUGH CONNECTED CARES, } \\
\text { APPROACH, IN A CASE OF HEMIPLEGIA AFTER } \\
\text { ISCHEMIC CARDIO-EMBOLIC STROKE WITHIN A } \\
\text { POLYPATHOLOGICAL CONTEXT }\end{array}$ & L28 \\
\hline $\begin{array}{l}\text { Ana Carmen Albesteanu, } \\
\text { Laura Georgiana Popescu, } \\
\text { Luminița Nirlu, Ali Osman Saglam, } \\
\text { Gelu Onose - } 12 \text { minutes }\end{array}$ & $\begin{array}{l}\text { MULTIMODAL - REHABILITATIVE THERAPEUTICAL } \\
\text { APPROACHES IN A COMPLEX OF PATHOLOGY } \\
\text { INCLUDING POSSIBLY EVOLVING DISCARIOTIC } \\
\text { TYPE - CASE REPORT }\end{array}$ & L29 \\
\hline $\begin{array}{l}\text { Liliana PADURE, Cristian Adam, } \\
\text { Laura Fierbinteanu - } 12 \text { minutes }\end{array}$ & $\begin{array}{l}\text { ATTACHMENT - PROGNOSTIC FACTOR IN MEDICAL } \\
\text { RECOVERY }\end{array}$ & L30 \\
\hline $\begin{array}{l}\text { Prof. Alexandru Vlad Ciurea } \\
-20 \text { minutes }\end{array}$ & MOTILITY OR MORBIDITY IN NEUROSURGERY & L31 \\
\hline $\begin{array}{l}\text { Valerica CREANGA-ZARNESCU, Ana-Maria } \\
\text { FATU, Anamaria CIUBARA, Violeta SA- } \\
\text { PIRA,Aurelia ROMILA, Mihaela LUNGU - } \\
12 \text { minutes }\end{array}$ & $\begin{array}{l}\text { EXERCISES PROGRAM AND REHABILITATION IN } \\
\text { PARKINSON'S DISEASE }\end{array}$ & L32 \\
\hline $\begin{array}{l}\text { Irina VERINCEANU, } \\
\text { Alice MUNTEANU, Andreea STOICA, } \\
\text { Stefan ISPAS - } 12 \text { minutes }\end{array}$ & $\begin{array}{l}\text { THE CARDIAC REHABILITATION IN PATIENTS WITH } \\
\text { ACUTE MYOCARDIAL INFARCTION }\end{array}$ & L33 \\
\hline $\begin{array}{l}\text { Marius Turnea, Catalin lonite, } \\
\text { Mihai Ilea, Dragos Arotaritei } \\
-12 \text { minutes }\end{array}$ & $\begin{array}{l}\text { STATISTICAL ANALYSIS OF PHYSIOTHERAPEUTIC } \\
\text { MEANS USED IN THE RECOVERY OF MUSCLE } \\
\text { INJURIES IN ATHLETES }\end{array}$ & L34 \\
\hline $\begin{array}{l}\text { Mihaiela CHICU, Eugen BITERE } \\
\text { - } 10 \text { minutes }\end{array}$ & $\begin{array}{l}\text { THE ROLE OF ILIB IN CARTILAGINOUS } \\
\text { DISTRUCTION IN RHEUMATOID ARTHRITIS }\end{array}$ & L35 \\
\hline $\begin{array}{l}\text { Mihaiela CHICU, Eugen BITERE } \\
-10 \text { minutes }\end{array}$ & $\begin{array}{l}\text { THE ROLE OF THE INFLAMMASOMS IN THE } \\
\text { PATHOGENESIS OF INFLAMMATORY REACTION }\end{array}$ & L36 \\
\hline
\end{tabular}


Thursday- 05 September 2019- Botanical Garden of Galați

11,45 -13,45 - World Spinal Cord Injury Day - Dedicated scientific session

Chairmen: Gelu ONOSE, Corina SPOREA, Aura SPÎNU

\begin{tabular}{|c|c|c|}
\hline Authors & Title & Abstract \\
\hline $\begin{array}{l}\text { Gelu Onose, (Keynote Speaker) } \\
\text { Vlad Ciobanu, } \\
\text { Corina Sporea } \\
-20 \text { minutes }\end{array}$ & $\begin{array}{l}\text { A TOPICAL SYSTEMATIC LITERATURE REVIEW AND REAP- } \\
\text { PRAISAL ON ESSAYS TOWARDS SYSTEMATIZING CLINICAL } \\
\text { ASSESSMENT INSTRUMENTS USED TO EVALUATE NEURO- } \\
\text { FUNCTIONAL DEFICITS AFTER SPINAL CORD INJURIES, } \\
\text { MAINLY IN ADULTS, INCLUDING THROUGH THE ICF(-DH) } \\
\text { CONCEPTUAL FRAMEWORK }\end{array}$ & L37 \\
\hline $\begin{array}{l}\text { Diana-Elena SERBAN, Aurelian } \\
\text { ANGHELESCU, Elena CONSTANTIN, } \\
\text { Gelu ONOSE - } 12 \text { minutes }\end{array}$ & $\begin{array}{l}\text { THE ACQUISITION OF SELF-DEFENSE TECHNIQUES AND } \\
\text { PROCEDURES AGAINST THE ACT OF AGGRESSION IN THE } \\
\text { PACIENT WITH PARAPLEGIA, WHEEL-CHAIR INDEPENDENT }\end{array}$ & L38 \\
\hline $\begin{array}{l}\text { Aurelian Anghelescu, } \\
\text { Elena Constantin, } \\
\text { Anca Sanda Mihaescu, } \\
\text { Gelu Onose } \\
\text { - } 12 \text { minutes }\end{array}$ & $\begin{array}{l}\text { “PREVENTION IS CURE, EDUCATION IS ESSENTIAL” - } \\
\text { RESPONSIBLE IMPLICATION OF YOUNG PEOPLE IN } \\
\text { EDUCATIONAL AND PROPHYLACTIC ACTIONS AGAINST } \\
\text { ACCIDENTAL CERVICAL SPINAL CORD INJURY AND SEVERE } \\
\text { DISABILITIES BY DIVING IN UNVERIFIED WATERS. }\end{array}$ & L39 \\
\hline $\begin{array}{l}\text { Alexandra SPORICI, } \\
\text { Irina ANGHEL, } \\
\text { Lapadat MAGDALENA, } \\
\text { Gelu ONOSE - } 12 \text { minutes }\end{array}$ & $\begin{array}{l}\text { RECOVERABLE RESULTS AT A PATIENT WITH AIS/FRANKEL } \\
\text { D INCOMPLETE TETRAPLEGIA / POST SPINAL CORD INJURY } \\
\text { BY FALLING FROM A HEIGHT, ON AN ANKYLOSING } \\
\text { SPONDYLITIS BACKGROUND }\end{array}$ & L40 \\
\hline $\begin{array}{l}\text { loana ANDONE, Carmen CHIPĂRUȘ, } \\
\text { Andreea FRUNZA, Aura SPÎNU, } \\
\text { Simona STOICA, Liliana ONOSE, } \\
\text { George PATRASCU, } \\
\text { Gelu ONOSE -12 minutes }\end{array}$ & $\begin{array}{l}\text { CLINICAL, PARACLINICAL ASPECTS AND COMPLEX THERA- } \\
\text { PEUTICAL APPROACHES IN A PATIENT WITH INCOMPLETE } \\
\text { PARAPLEGIA, POST THORACIC MENIGIOMA SURGICALLY } \\
\text { TREATED, IN NEUROFIBROMATOSIS CONTEXT }\end{array}$ & L41 \\
\hline $\begin{array}{l}\text { Cristina Octaviana DAIA, } \\
\text { Alina-Elena Gherghiceanu, } \\
\text { Helene Ivan, } \\
\text { Gelu ONOSE - } 12 \text { minutes }\end{array}$ & $\begin{array}{l}\text { RESEARCH ON NEUROREHABILITATION } \\
\text { RESULTS IN VERTEBRO-MEDULLARY } \\
\text { POST-TRAUMATIC CONDITIONS ASSOCIATING FRACTURES, } \\
\text { IN A POLITRAMATIC CONTEXT }\end{array}$ & L42 \\
\hline $\begin{array}{l}\text { Ali-Osman Saglam, } \\
\text { Alexandru G. Stavrica, } \\
\text { Ana Carmen Albeșteanu, } \\
\text { Laura Georgiana Popescu, } \\
\text { Luminita Nirlu, } \\
\text { Gelu Onose - } 12 \text { minutes }\end{array}$ & $\begin{array}{l}\text { MEDICAL-REHABILITATION ENDEAVORS, CARE INTERVEN- } \\
\text { TIONS AND CONNOTATIONS OF A MEDICO-SOCIAL TYPE, IN } \\
\text { A COMPLEX POLYPATHOLOGICAL CASE: PARAPLEGIA, } \\
\text { SPONDYLODISCITIS, KIDNEY FAILURE IN THE HAEMODIALY- } \\
\text { SIS STAGE AND BILATERAL NEPHROSTOMIES AFTER SURGI- } \\
\text { CALY TREATTED BLADDER NEOPLASM. }\end{array}$ & L43 \\
\hline $\begin{array}{l}\text { Sorina Petrușan-Dunca, } \\
\text { Liviu Lazăr, Tiberiu-Dorin Corha } \\
\text { - } 12 \text { minutes }\end{array}$ & $\begin{array}{l}\text { INDICATIONS AND LIMITIS OF REHABILITATION } \\
\text { TREATMENT FOR LUMBAR DISCOPATHY IN PREGNACY }\end{array}$ & L44 \\
\hline
\end{tabular}


Thursday- 05 September 2019- Botanical Garden of Galați

15,00 -17,00 - Scientific session VI

Chairmen: Liliana- Elena STANCIU, Simona CARNICIU, Simona Isabelle STOICA

\begin{tabular}{|c|c|c|}
\hline Authors & Title & Abstract \\
\hline $\begin{array}{l}\text { Elena Silvia SHELBY, Mihaela AXENTE, } \\
\text { Liliana PĂDURE - } 12 \text { minutes }\end{array}$ & $\begin{array}{l}\text { CHARCOT MARIE TOOTH DISEASE. CASE PRESENTATION. } \\
\text { GENETIC DISEASES WHICH REQUIRE PHYSICAL } \\
\text { REHABILITATION }\end{array}$ & $\begin{array}{l}\mathrm{L} 45 \\
\mathrm{~L} 46\end{array}$ \\
\hline $\begin{array}{l}\text { Simona Carniciu } \\
-12 \text { minutes }\end{array}$ & $\begin{array}{l}\text { INFLUENCE OF NUTRITION AND EXERCISE ON THE USE } \\
\text { OF DIFFERENT ENERGY SUBSTRATES IN THE } \\
\text { PREVENTION OF METABOLIC DISEASES }\end{array}$ & L81 \\
\hline $\begin{array}{l}\text { Simona-Isabelle STOICA, } \\
\text { Carmen Elena CHIPĂRUȘ, } \\
\text { Magdalena Vasilica LAPADAT, } \\
\text { George PĂTRAȘCU, } \\
\text { Gelu ONOSE - } 12 \text { minutes }\end{array}$ & $\begin{array}{l}\text { CLINICAL-THERAPEUTIC AND RECUPERATORY } \\
\text { FEATURES IN A PATIENT WITH PLURIPATOLOGY: ISCHE- } \\
\text { MIC STROKE, ISCHEMIC HEART DISEASE (SECHELAR } \\
\text { MYOCARDIAL INFARCTION), CHRONIC KIDNEY DISEASE } \\
\text { AND MONSTROUS GOUT- CASE PRESENTATION }\end{array}$ & L47 \\
\hline $\begin{array}{l}\text { Eugen BITERE, Mihaiela CHICU } \\
-12 \text { minutes }\end{array}$ & $\begin{array}{l}\text { PATHOPHYSIOLOGY OF ATHEROGENESIS AND CARDIO- } \\
\text { VASCULAR RISK IN CHRONIC INFLAMMATORY DISEASES }\end{array}$ & $\mathrm{L} 48$ \\
\hline $\begin{array}{l}\text { Victoria CHIHAI, Alisa TĂBîRȚ̆, } \\
\text { Anastasia ROTĂREANU, Vladlena } \\
\text { MIHAILOV, } \\
\text { Mihail CîRîM - } 12 \text { minutes }\end{array}$ & $\begin{array}{l}\text { THE IMPACT OF ACTIVE KINETIC PROGRAMS ON CLINI- } \\
\text { CAL AND FUNCTIONAL STATUS ADRESSED TO PEOPLE } \\
\text { WITH DIABETIC ANGIOPATHY }\end{array}$ & L49 \\
\hline $\begin{array}{l}\text { Ana-Maria Fătu, Ana Maria Pâslaru, } \\
\text { Valerica Creangă-Zărnescu, } \\
\text { Alexandru Nechifor, Mădălina } \\
\text { Verenca, Mihaela Lungu, } \\
\text { Anamaria Ciubară - } 12 \text { minutes }\end{array}$ & $\begin{array}{l}\text { THE IMPACT OF COGNITIVE DECLINE ON STROKE } \\
\text { REHABILITATION }\end{array}$ & L50 \\
\hline $\begin{array}{l}\text { Alisa TĂBîRṬĂ, Victoria CHIHAI } \\
\text { - } 12 \text { minutes }\end{array}$ & $\begin{array}{l}\text { THE USE OF TRINITY AMPUTATION AND PROSTHESIS } \\
\text { EXPERIENCE SCALES IN THE COMPLEX REHABILITATION } \\
\text { OF PERSONS WITH LOWER LIBM AMPUTATION }\end{array}$ & L51 \\
\hline $\begin{array}{l}\text { Ilie ONU, Mariana ROTARIU, Elvina } \\
\text { MIHALAȘ, Călin CORCIOVĂ } \\
\text { - } 12 \text { minutes }\end{array}$ & $\begin{array}{l}\text { STUDY ON EFFICIENCY OF ELECTROTHERAPY AND } \\
\text { PHYSIOTHERAPY MANAGEMENT ON HERNIATED LUM- } \\
\text { BAR DISC }\end{array}$ & L52 \\
\hline $\begin{array}{l}\text { María G. Souto Figueroa, } \\
\text { Antonio Freire Magariños }\end{array}$ & $\begin{array}{l}\text { RESEARCH - SURVEY TO } 142 \text { THERMALIST WHO HAVE } \\
\text { PERFORMED A THERMAL CURE AT THE BATHS OF BA- } \\
\text { NOS DE MOLGAS (OURENSE) AND AUGAS SANTAS } \\
\text { (LUGO) - GALICIA - SPAIN }\end{array}$ & L53 \\
\hline
\end{tabular}


Friday- 06 September 2019

09,30 -11,30 - Scientific session VII

Chairmen: Otilia ROGOVEANU, Gabriela DOGARU, Mihaela DUȚESCU

\begin{tabular}{|c|c|c|}
\hline Authors & Title & Abstract \\
\hline $\begin{array}{l}\text { Irina lonica } \\
-12 \text { minutes }\end{array}$ & $\begin{array}{l}\text { ACUPUNCTURE IN REHABILITATION - A } \\
\text { GENERAL VIEW }\end{array}$ & L54 \\
\hline $\begin{array}{l}\text { Denisa COAJĂ, Gabriela DOGARU } \\
-12 \text { minutes }\end{array}$ & $\begin{array}{l}\text { THE HEALTH BENEFITS OF FINNISH SAUNA } \\
\text { BATHING }\end{array}$ & L55 \\
\hline $\begin{array}{l}\text { Otilia ROGOVEANU, Florin GHERGHINA, } \\
\text { Rodica TRAISTARU - } 12 \text { minutes }\end{array}$ & $\begin{array}{l}\text { SPINA BIFIDA - FUNCTIONAL } \\
\text { REHABILITATION METHODS IN CHILDREN }\end{array}$ & L56 \\
\hline $\begin{array}{l}\text { Mihaela DUTESCU, } \\
\text { Raluca OLTEAN, Petru NENADICI } \\
-12 \text { minutes }\end{array}$ & $\begin{array}{l}\text { GEOAGIU BAI RESORT - OUR EXPERIENCE } \\
\text { OF MEDICAL REHABILITATION TREATMENT }\end{array}$ & L57 \\
\hline $\begin{array}{l}\text { Dumitru MIHĂILĂ, } \\
\text { SILISTEANU Sinziana Calina, } \\
\text { TIICULEANU Mihaela (Ciurlică) } \\
\text { - } 12 \text { minutes }\end{array}$ & $\begin{array}{l}\text { THE METEOROLOGICAL COMPLEX AND THE } \\
\text { HUMAN PATHOLOGY. } \\
\text { CASE STUDY - SUCEAVA COUNTY }\end{array}$ & L58 \\
\hline $\begin{array}{l}\text { Mariana VARODI, } \\
\text { Gabriela DOGARU } \\
-12 \text { minutes }\end{array}$ & $\begin{array}{l}\text { EFFICACY OF NATURAL THERAPEUTIC } \\
\text { FACTORS FROM OCNA SIBIULUI SPA RESORT } \\
\text { IN GONARTHROSIS }\end{array}$ & L59 \\
\hline $\begin{array}{l}\text { Boróka-Panna GÁSPÁR, } \\
\text { Gabriela DOGARU } \\
\text { - } 12 \text { minutes }\end{array}$ & BONE HYDRATION AND MINERAL WATERS & L60 \\
\hline $\begin{array}{l}\text { CALIN BOCHIS, LIVIU LAZAR, } \\
\text { HORAȚIU URECHESCU, } \\
\text { CARMEN NISTOR-CSEPPENTO, } \\
\text { FELICIA CIOARA, NICOLETA PASCALAU, ALIN } \\
\text { BOCHIS, DIANA IOVANOVICI } \\
\text { - } 12 \text { minutes }\end{array}$ & $\begin{array}{l}\text { CORRELATION OF VAS PAIN SCORE WITH } \\
\text { FUNCTION AT THE PACIENTS WITH } \\
\text { TEMPOROMANDIBULAR OSTEOARTHRITIS }\end{array}$ & L61 \\
\hline $\begin{array}{l}\text { Marian Romeo CALIN, lleana RADULESCU, } \\
\text { Mihaela Antonina CALIN, } \\
\text { Elena Roxana ALMASAN } \\
\text { - } 12 \text { minutes }\end{array}$ & $\begin{array}{l}\text { RADIOMETRIC ASSESSMENT OF PELOID AND } \\
\text { SALT WATER USED FOR THERAPY AND } \\
\text { BALNEARY TRATAMENT FROM TECHIRGHIOL } \\
\text { LAKE, ROMANIA }\end{array}$ & L62 \\
\hline
\end{tabular}


Friday- 06 September 2019

$12,00-14,00$ Scientific session VIII

Chairmen: Constantin MUNTEANU, Paraschiva POSTOLACHE, Dragoș AROTĂRIṬEI

\begin{tabular}{|c|c|c|}
\hline Authors & Title & Abstract \\
\hline $\begin{array}{l}\text { Cristina PETRESCU } \\
-12 \text { minutes }\end{array}$ & $\begin{array}{l}\text { EFFICACY NATURAL THERAPEUTIC FACTORS FROM } \\
\text { BAILE GOVORA IN BRONCHIAL ASTHMA }\end{array}$ & L63 \\
\hline $\begin{array}{l}\text { PARASCHIVA POSTOLACHE } \\
-12 \text { minutes }\end{array}$ & $\begin{array}{l}\text { PULMONARY REHABILITATION SAVES LIVES AND } \\
\text { IMPROVES LIFE }\end{array}$ & L64 \\
\hline $\begin{array}{l}\text { DOINA-CLEMENTINA COJOCARU, } \\
\text { PARASCHIVA POSTOLACHE } \\
\text { - } 12 \text { minutes }\end{array}$ & $\begin{array}{l}\text { ASSESSMENT OF DYSPNEA IN PULMONARY RE- } \\
\text { HABILITATION PRACTICE }\end{array}$ & L65 \\
\hline $\begin{array}{l}\text { PARASCHIVA POSTOLACHE, } \\
\text { CRISTINA LACATUSI } \\
-12 \text { minutes }\end{array}$ & $\begin{array}{l}\text { HELIOTHERAPY, CLIMATOTHERAPY AND PATIENTS } \\
\text { WITH RESPIRATORY DISEASES }\end{array}$ & L66 \\
\hline $\begin{array}{l}\text { CONSTANTIN MUNTEANU, } \\
\text { DIANA MUNTEANU, MIHAIL HOTETEU } \\
\text { - } 12 \text { minutes }\end{array}$ & BIOLOGICAL INSIGHTS OF SPELEOTHERAPY & L67 \\
\hline $\begin{array}{l}\text { PARASCHIVA POSTOLACHE, } \\
\text { CRISTINA LACATUSI, } \\
\text { DOINA-CLEMENTINA COJOCARU } \\
-12 \text { minutes }\end{array}$ & AEROSOLS AND BREATHING & L68 \\
\hline $\begin{array}{l}\text { PARASCHIVA POSTOLACHE, } \\
\text { MADALINA ZEBEGA } \\
-12 \text { minutes }\end{array}$ & $\begin{array}{l}\text { RESPIRATORY MUSCLE TRAINING AND RESPIRATO- } \\
\text { RY REHABILITATION }\end{array}$ & L69 \\
\hline $\begin{array}{l}\text { CRISTI FRENȚ, GEORGETA MAIORESCU } \\
\text { - } 12 \text { minutes }\end{array}$ & $\begin{array}{l}\text { DEVELOPMENTS AND INVOLUTIONS OF TOURISM } \\
\text { IN THE SPA RESORTS IN ROMANIA AND THE CASE } \\
\text { STUDY FOR LACUL SĂRAT RESORT }\end{array}$ & L70 \\
\hline $\begin{array}{l}\text { Dragos Arotaritei, } \\
\text { Andrei Gheorghita, } \\
\text { Mariana Rotariu, } \\
\text { Marius Turnea - } 12 \text { minutes }\end{array}$ & $\begin{array}{l}\text { MATHEMATICAL MODEL OF SULPHUR } \\
\text { ABSORPTION PROCESS, A POSSIBLE APPLICATION } \\
\text { IN CURE WITH SULPHUROUS MINERAL WATER }\end{array}$ & L71 \\
\hline
\end{tabular}


Friday- 06 September 2019

$15,00-17,00$ - Scientific session IX

Chairmen: Liviu LAZAR, Dan BLENDEA, Carmen FIRAN, Dorin-Gheorghe TRIFF

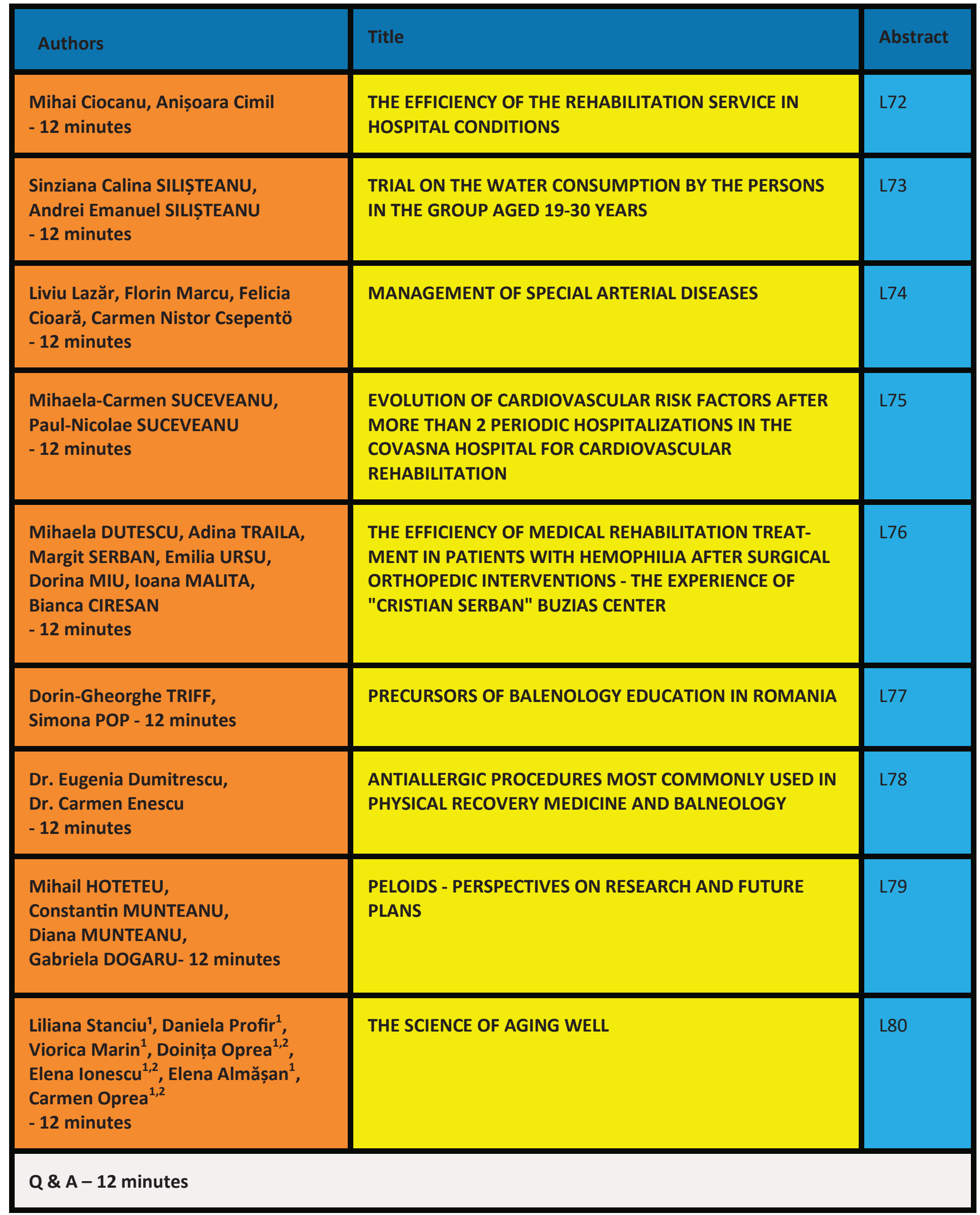


Wednesday - 04 September 2019- Botanical Garden of Galați, 17,00 -17,30

\begin{tabular}{|c|c|c|}
\hline Authors & Title & Abstract \\
\hline $\begin{array}{l}\text { Andra Pintilie, Liliana Pădure, } \\
\text { Andrada Mirea, Corina Sporea }\end{array}$ & $\begin{array}{l}\text { Proprioceptive Functional Vibration Stimulation as } \\
\text { therapeutic tool in spasticity management of jump gait } \\
\text { pattern of spastic diplegic children with cerebral palsy }\end{array}$ & Poster - 1 \\
\hline $\begin{array}{l}\text { Andra Pintilie, Liliana Pădure, } \\
\text { Andrada Mirea, Corina Sporea }\end{array}$ & $\begin{array}{l}\text { Modern computerized techniques for gait's functional } \\
\text { evaluation through a specialized wireless inertial sensor - } \\
\text { premise for orthopedic corrective shoes wear in children } \\
\text { with gait disorders secondary to Cerebral Palsy }\end{array}$ & Poster - $\underline{2}$ \\
\hline $\begin{array}{l}\text { Ana Maria PÂSLARU, Ana Maria } \\
\text { FĂTU, Anamaria CIUBARĂ }\end{array}$ & The role of medical recovery in oncology & Poster $-\underline{3}$ \\
\hline $\begin{array}{l}\text { Maria Veronica MORCOV, } \\
\text { Liliana PADURE, } \\
\text { Cristian Gabriel MORCOV, } \\
\text { Gelu ONOSE }\end{array}$ & $\begin{array}{l}\text { Exercises availed by sensor-based computer advanced } \\
\text { devices: part of the interactive cognitive recovery - adju- } \\
\text { vant of the therapy applied in the Centrul National Clinic de } \\
\text { Recuperare Neuropsihomotorie Copii "Dr. N. Robanescu" }\end{array}$ & Poster - $\underline{4}$ \\
\hline $\begin{array}{l}\text { Avram Mihai, } \\
\text { Liliana Padure, } \\
\text { Gelu Onose }\end{array}$ & $\begin{array}{l}\text { Theoretical fundamentals and conceptual premise for ad- } \\
\text { vanced proprioceptive and sensory stimulus apparatus, with } \\
\text { sequential evaluation for the treatment of the recuperator } \\
\text { in the equilibrium disorder, from Cerebral Palsy (PC) casu- } \\
\text { istry. }\end{array}$ & Poster $-\underline{5}$ \\
\hline $\begin{array}{l}\text { Andrada MIREA, Gelu ONOSE, } \\
\text { Madalina LEANCA, Florin-Petru } \\
\text { GRIGORAS, Mihaela AXENTE, } \\
\text { Liliana PADURE, Corina SPOREA }\end{array}$ & $\begin{array}{l}\text { Respiratory management in patients with rare } \\
\text { progressive neuromuscular diseases }\end{array}$ & Poster $-\underline{6}$ \\
\hline $\begin{array}{l}\text { Mihaela MANDU, Elena CONSTAN- } \\
\text { TIN, Cristinel Dumitru BADIU, } \\
\text { Cosmin Daniel OPREA, } \\
\text { Cristina DAIA, Gelu ONOSE }\end{array}$ & $\begin{array}{l}\text { Presentation od the Fugl Meyer Assesment scale and } \\
\text { related suggesttion in order to enhance its level of } \\
\text { implementation in inner neurorehabilitation units }\end{array}$ & Poster - $\underline{7}$ \\
\hline $\begin{array}{l}\text { ALEXANDRU BOGDAN-CĂTĂLIN, } \\
\text { ALINA SIMONA ȘOVREA, } \\
\text { ANNE-MARIE CONSTANTIN, } \\
\text { ADINA BIANCA BOȘCA, CARMEN } \\
\text { GEORGIU, MONICA POPA }\end{array}$ & $\begin{array}{l}\text { Complex oral rehabilitation in an elderly patient with } \\
\text { periodontal disease who exercises regularly }\end{array}$ & Poster - $\underline{8}$ \\
\hline $\begin{array}{l}\text { Dorin-Gheorghe TRIFF, } \\
\text { Simona POP }\end{array}$ & $\begin{array}{l}\text { MORBIDITY BY OSTEO-MUSCULO-ARTICULAR DISEASES IN } \\
\text { THE OCCUPATIONAL ENVIRONMENT IN MARAMURES } \\
\text { COUNTY. THE IMPORTANCE OF MEDICAL RECOVERY AND } \\
\text { RECORDS THROUGH ELECTRONIC DATA MANAGEMENT } \\
\text { SYSTEMS }\end{array}$ & Poster - $\underline{9}$ \\
\hline
\end{tabular}


Thursday- 05 September 2019- Botanical Garden of Galați, 17,00 -17,45

\begin{tabular}{|c|c|c|}
\hline Authors & Title & Abstract \\
\hline $\begin{array}{l}\text { Mihaela Antonina CALIN, Marian } \\
\text { Romeo CALIN, Constantin Munteanu }\end{array}$ & $\begin{array}{l}\text { New evidence on the effects of pelotherapy on } \\
\text { local microcirculation }\end{array}$ & Poster 10 \\
\hline $\begin{array}{l}\text { Izabela Lazar, } \\
\text { Gabriela Dogaru }\end{array}$ & $\begin{array}{l}\text { The effectiveness of balnear treatment in the } \\
\text { management of psoriasis }\end{array}$ & Poster 11 \\
\hline $\begin{array}{l}\text { Dorin-Gheorghe TRIFF, } \\
\text { Mușata Dacia BOCOȘ }\end{array}$ & $\begin{array}{l}\text { CORRELATIONS OF OSTEOMUSCULO-ARTICULAR } \\
\text { DISEASES WITH WORK ABILITY, PERCEIVED SELF } \\
\text { EFFICACY AND OCCUPATIONAL STRESSORS AT A } \\
\text { REGULAR MEDICAL CHECK-UP IN PRE-UNIVERSITY } \\
\text { EDUCATION UNITS }\end{array}$ & Poster $\underline{12}$ \\
\hline $\begin{array}{l}\text { Doroteea Teoibas-Serban, } \\
\text { Valentin Stan, Dan Blendea }\end{array}$ & $\begin{array}{l}\text { PREVENTION OF LUMBAR DISC HERNIATION IN } \\
\text { YOUNG ADULT POPULATION: A PRACTICAL } \\
\text { APPROACH }\end{array}$ & Poster $\underline{13}$ \\
\hline $\begin{array}{l}\text { Călin Corciovă, Cătălina Luca, } \\
\text { Robert Fuior, Flavia Corciovă }\end{array}$ & $\begin{array}{l}\text { Development a Monitoring Device for Arm } \\
\text { Rehabilitation }\end{array}$ & Poster 14 \\
\hline $\begin{array}{l}\text { Simona Daniela Zavalichi, } \\
\text { Marius Andrei Zavalichi, } \\
\text { Sorin Stratulat, Florin Mitu }\end{array}$ & $\begin{array}{l}\text { Cardiovascular rehabilitation: challenges in a case } \\
\text { of acute myocardial infarction and familial } \\
\text { hypercholesterolemia }\end{array}$ & Poster $\underline{15}$ \\
\hline $\begin{array}{l}\text { Simona-Isabelle STOICA, } \\
\text { loana TANASE, Gelu ONOSE }\end{array}$ & $\begin{array}{l}\text { Influences and consequences resulting in } \\
\text { addictions in general and to chronic alcoholism, } \\
\text { especially for patients with spinal cord injury }\end{array}$ & Poster 16 \\
\hline $\begin{array}{l}\text { Roxana Dumitrascu, Ana } \\
\text { Maria Bumbea, Carmen Albu, Otilia } \\
\text { Rogoveanu, Catalin Bostina, } \\
\text { Rodica Traistaru, Borcan Madalina }\end{array}$ & $\begin{array}{l}\text { BIOMECHANICAL DYSFUNCTIONS OF THE } \\
\text { FOOT - MAJOR IMPACT ON THE KINETIC CHAIN }\end{array}$ & Poster $\underline{17}$ \\
\hline $\begin{array}{l}\text { Otilia Rogoveanu, Gherghina Florin, } \\
\text { Caimac Dan, Trifu Ramona, } \\
\text { Cruceru Andra, Beldie C }\end{array}$ & $\begin{array}{l}\text { Medical rehabilitation in post-stroke spastic } \\
\text { hemiparesis in young patients }\end{array}$ & Poster 18 \\
\hline $\begin{array}{l}\text { Ana Maria Bumbea, Otilia Rogoveanu, } \\
\text { Roxana Dumitrascu, Bogdan Stefan Bumbea, } \\
\text { Catalin Bostina, Albu Carmen, } \\
\text { Borcan Madalina }\end{array}$ & $\begin{array}{l}\text { PERIPHERAL MAGNETIC STIMULATION - A } \\
\text { CHALLENGE IN VERTEBRAL POSTTRAUMATIC } \\
\text { RECOVERY }\end{array}$ & Poster $\underline{19}$ \\
\hline Dănuţ PĂCURAR, Mihaela Ramona PĂCURAR & $\begin{array}{l}\text { KNEE ARTHROPLASTY RECOVERY OF AN CANCER } \\
\text { PATIENT }\end{array}$ & Poster $\underline{20}$ \\
\hline Dănuţ PĂCURAR, Mihaela Ramona PĂCURAR & $\begin{array}{l}\text { THE IMPACT OF OSTEOARTICULAR PATHOLOGY IN } \\
\text { POSTSTROKE RECOVERY }\end{array}$ & Poster 21 \\
\hline
\end{tabular}




\begin{tabular}{|c|c|c|}
\hline Authors & Title & Abstract \\
\hline $\begin{array}{l}\text { Borcan Madalina, Bumbea Ana Maria, Bostina } \\
\text { Catalin, Radoi Georgeta, Bumbea Bogdan }\end{array}$ & $\begin{array}{l}\text { EFFICIENT REHABILITATION TREATMENT IN A CASE } \\
\text { WITH MAV-RUPTA MALFORMATION }\end{array}$ & Poster $\underline{22}$ \\
\hline $\begin{array}{l}\text { Demirgian Sibel, Nan Simona, Lulea Adela, } \\
\text { Lascu loana, Marin Viorica }\end{array}$ & $\begin{array}{l}\text { Is possible the management of synovial } \\
\text { chondromatosis of the hip by arthroscopy or } \\
\text { complex balneal treament? }\end{array}$ & Poster $\underline{23}$ \\
\hline $\begin{array}{l}\text { Mădălina Codruța Verenca, Sorina Mierlan, } \\
\text { Claudiu Elisei Tanase }\end{array}$ & $\begin{array}{l}\text { The Efficiency of Medical Treatment of } \\
\text { Scoliosis - Paediatrics }\end{array}$ & Poster 24 \\
\hline $\begin{array}{l}\text { Florentina NASTASE }{ }^{1} \text {, Alin Laurentiu TATU }{ }^{2} \text {, } \\
\text { Madalina Codruta VERENCA }\end{array}$ & $\begin{array}{l}\text { Orthopaedic manifestations of Neurofibromatosis } \\
\text { type } 1 \text { - case report }\end{array}$ & Poster 25 \\
\hline $\begin{array}{l}\text { Simona CARNICIU, Anatolie BACIU, Vasile } \\
\text { FEDAS }\end{array}$ & $\begin{array}{l}\text { The attenuation of energy metabolic misbalance } \\
\text { by means of aerobic, hypoxic, hypothermal } \\
\text { adaptation and environment optimization at } \\
\text { recreation resort center }\end{array}$ & Poster 26 \\
\hline $\begin{array}{l}\text { Irina Anghel, Alexandra Sporici, } \\
\text { Magdalena Lapadat, Gelu Onose }\end{array}$ & $\begin{array}{l}\text { Complex clinical and therapeutic rehabilitation } \\
\text { approach of a patient with Complete AIS/Frankel } \\
\text { A quadriplegia post cervical spinal cord injury after } \\
\text { accidental fall off a trailer and multiple } \\
\text { complications occurring during disease } \\
\text { progression - case study }\end{array}$ & Poster 27 \\
\hline $\begin{array}{l}\text { Ana-Maria Pelin , Monica Georgescu , Cristina } \\
\text { Stefanescu, Costinela Georgescu }\end{array}$ & Molecular treatment strategies in osteoporosis & Poster 28 \\
\hline
\end{tabular}

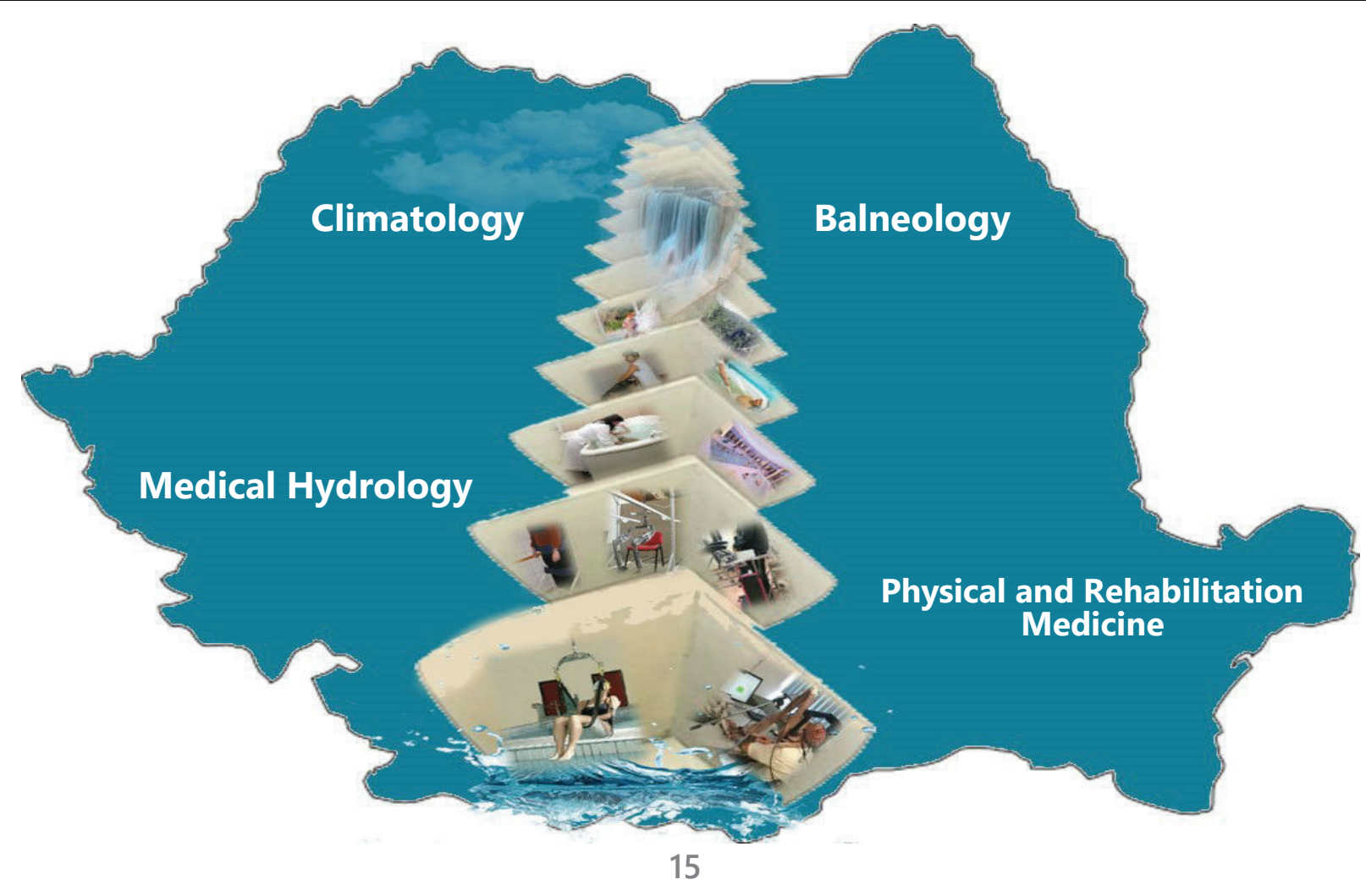




\section{L1 -Perspectives of Balneology - International data inputs, National outputs}

\section{Constantin MUNTEANU ${ }^{1,2}$, Diana MUNTEANU ${ }^{1,3}$, Mihail HOTETEU ${ }^{1,4}$, Gabriela DOGARU ${ }^{1,5}$}

Corresponding author: Constantin MUNTEANU, E-mail: office@bioclima.ro,

1. Romanian Association of Balneology, Bucharest, Romania

2. Emergency Clinical Hospital Bagdasar-Arseni, Bucharest, Romania 3. National Institute of Rehabilitation, Physical Medicine and Balneoclimatology, Bucharest, Romania

4. Biosafety LTD, Bucharest, Romania

Abstract

5. Iuliu Hațieaganu Medical and Pharmacy University, Cluj-Napoca, Romania

Introduction. Balneology has a long European and Asian tradition and Romania can be the cornerstone of international bridges in this area due to its geographical position, legendary tradition and extraordinary natural resources of all kind. The use of thermal and mineral springs on the territory of the country for health and treatment purposes is a tradition with a history of more than two thousand years. Unique spa resources, such as thermal and mineral springs, mud, mofetes, saline microclimate, bioclimate (spasmodic, exciting marine seafront or quay, stimulant tonic), are used successfully in the sphere of health care services, preventive medical action, rehabilitation and wellness. Legend of Hercule bathing in Cerna's waters is a proof of the use of thermal waters long before the Roman conquest. This tradition exists in almost all civilizations. Today it maintains its usefulness and is spread across all continents, mainly in the Middle East and South and East Europe, Asia (Middle East, Japan, China, Turkey), South America (Argentina, Mexico, Colombia) and North Africa (Morocco, Tunisia) (244-249). For many medical problems such as those dermatological, allergies, pulmonary, rheumatic, gynecological, and many other problems, but especially for disease prevention, stress reduction, prophylaxis and recreation, the use of natural therapeutic factors through spa/balneary tourism represents a solution targeted by the international scientific community through different experts and by medical, social and environmental programs.

Natural therapeutic factors can not have an effective promotion on a globalized tourist market and with remarkable competitors without scientific research. Each balneary resort begins its story with the discovery of natural factors whose therapeutical value has been clinically and experimentally proven by scientific personalities of that time (244-249).

The dissemination of information has led to the reputation of the locality, and the character of the spa resort has been achieved through a good promotion of the therapeutic quality of the natural factors discovered. In balneary tourism, the importance of researching natural resources is essential for the development of a balneary resort promotion plan, thus providing information on the therapeutic properties of natural factors, their contribution to our health and the biological mechanisms by which they act on our body.

The Romanian Balneology Association has as its main objective the promotion of Balneology through scientific research, but to achieve this objective, the participation of local communities, local and central public authorities, those operating in this sector or treatment base holders is essential.

Material and method. This article is a sistematic and summarizing review of all published articles by Balneo Research Journal in its ten years of existence, from november 2010 until September 2019. All the ten volumes and more than 250 articles were analized in order to understand the main thematic of the articles, the more usefull scientific concepts, the realistic benefits of the published articles for the development of Balneology. Results and discussions. Analizing an article database of about 250 publised articles in Balneo Research Journal can be of real impact on the development of the field of Balneology but also can drive the future of the jurnal to better understand its implications in the scientific arena.

Conclusions. Main scientific concepts with wich Balneology is operating, interdisciplinary connections and authors interests were focused ideas to have in mind by the authors of this article.

Key words: Balneology, Balneotherapy, Balneo Research Journal, Natural therapeutic factors, Balneary Resort, 


\title{
L2 - CLIMATE AND HEALTH: A new challenge for an old science
}

\author{
Prof. Umberto Solimene \\ President of the World Federation of Hydrotherapy and Climatotherapy ( FEMTEC)
}

\section{(cc) BY-NC-ND}

The conference on climate change in Paris highlighted the possible significant increase in the incidence of diseases due to environmental changes, which may affect a variety of systems(respiratory,locomotor,and gastrointestinal) and millions of people, sometimes with fatal consequences (climate-1@lists.iisd.ca ).

Moreover,theWorld Health Organization(www.who.int) implemented several workshops, whose outcome was a set of important scientific documents with annexed guidelines (http://www.who.int/healthinfo/sage/ SAGE_Meeting_Dec2012_StoneA.pdf) concerning the evaluation of objective/subjective wellbeing as related to the socioeconomic environment.Along side these issues, a variety of forms of tourism aimed at health, experience, and awareness are being developed. TheThermae and the relevant regions are, therefore, important players in this challenge, which can be considered as a major one for modern civilization, namely environmental, human, and personal development and sustainability.

Thermal medicine, an old therapy that is currently applied in advanced countries according to strict scientific criteria, is now involved in this process to its full right and offers its potential for prevention, care, and rehabilitation to millions of patients all around the world. A stay at a thermal station, if well managed and organized, allows to "review" and "adjust" one's lifestyles, which are responsible for most active diseases.

The cultural and structural wealth of "thermal regions", sometimes a true legacy of the past experienced through a modern approach, is a natural "soul medicine" complement, according to a modern interpretation of complex body systems and $\mathrm{mind} /$ body relations.

All the above involves multiple components and also represents an important factor for the socioeconomic development of thermal regions. Environment, health resorts, and tourism are the pillars of a complex structure that may affect the quality of life both in health and economic terms. However,their harmonious development calls for analyses, evaluations, and practical proposals.

FEMTEC, in the vision of new integrated development models, engages with specialists and the National Government Institutions in charge of health and territorial planning.

In 1969 the CENTRE FOR RESEARCH ON MEDICAL BIOCLIMATOLOGY was founded in Italy, at the Milan University, by Professor Roberto Gualtierotti, later managed by Professor Umberto Solimene. The Centre's activities, connected with those of FEMTEC, can be reviewed at www.femteconline.org. They are primarily aimed at studying relations between human health and weather changes (meteoropathies); climate change and health; characterization of tourist thermal establishments for therapeutic purposes.

The Centre is now a Biometeorology Research Unit (Doctor V. Condemi) based at the Department of Biomedical Health Sciences, within the framework of the activity of the School of Motor Sciences (Professor F. Esposito), and has cooperation agreements in place with FEMTEC-WHO (Professor U. Solimene).

It is also very busy in the educational sphere, including with the recent event Labirinti d'acqua, organized on occasion of the World Water Day (www.labirintodacque.it).

By way of example, we hereby introduce a brochure on Italian climate and its characteristics according to its action on the individual human body systems.

In the 4th century B.C., with the treaty Airs, waters, and places [1], Hippocrates from Kos stressed - at the dawn of medicine - the utmost importance of the potential effects of the environment, and particularly, of climate on human health, as well as on its restoration during or after a disease. In another important work, Prognostics, Hippocrates focused on the structure of diseases, and in Epidemics he summarized the assumptions set out in Prognostics and the climatic and geographic conditions postulated in Airs, waters, and places. Today these intuitions are consistently confirmed by science based on the combination of two important factors: on one hand, a deep climate change is under way, and on the other the average life expectancy is increasing, particularly in industrialized countries, where new risk categories, unknown in the past, are now introduced alongside the classical fragile groups. As a result, the influence of weather and climatic factors on the pathogenesis of several illnesses has gradually been given solid 
scientific evidence. The broad scientific literature available on the topic includes epidemiological and clinical studies with a wide and documented range of adverse health outcomes observed after short and long-term exposure as a consequence of weather changes. Weather phenomena in general, and extreme ones in particular, are therefore part of a long and deep climate transformation process that has a clear epidemiological meaning forindividuals at risk, fragile groups, and vulnerable Country-systems. One example in this respect is acknowledged by the World Health Organization, which paid great attention to the fluctuations of the phenomenon El Nino (ENSO) that have important epidemiological consequences in broad regions of the world and for a variety of diseases. With a thorough search of literature, the WHO also analyzed the climatic system and its changes to build predictive models for specific infectious diseases and potential micro and macro-epidemics in a future projection (known as climate change sensitive diseases). Some of its Reports summarize consolidated scientific evidence [2 ], [3 ]. Several studies were carried out to understand the links between weather, climatic, and environmental conditions and the onset of illness, both acute and as an expression of new acute phases of disorders mostly affecting the respiratory tract and the cardiovascular system. Studies were also carried out on the number of patients admitted to the ER using measures of the association between diseases and winter weather conditions, Rusticucci et al [4]. Makle et al [5] focused on the links between weather factors and daily and weekly variability in patients admitted to the ER in Fukuoka, Japan. In another study, Kovats et al.[6] elaborated on the dual aspect of mortality and morbidity following an remarkable heat wave in London. Vulnerability and mortality correlated with heat waves in cities were broadly analyzed by, among others, Besancenot [7] using a general methodology on a national scale, and by Stafoggia et al. [8] with approaches focused on different populations of city dwellers. Following a contribution by Curriero et al. [9] embracing 11 US cities and funded by the European Commission Fifth Framework Programme, a complex European Research Project was carried out (Assessment and Prevention of Acute Health Effects and Weather Conditions in Europe - PHEWE - 2002-2005) with the main purpose to investigate associations between certain weather variables and their effects on human health (acute health effects) with a strictly epidemiological approach. The findings of this multi-centric study published by Michelozzi et al. [10] demonstrated a close association between heat waves and respiratory diseases, whereas a loose association was observed with cardiovascular diseases that called for admission to the ER. This applied research process also included specific Programmes, carried out with multi-centric and other approaches, aimed at designing and testing meteo-climatic-epidemiological models where the central role of the weather-climate-human health relation promoted the creation of mitigation and/or prevention models. Most investigations only focused on individual cities and the relevant urban context. Only a brief list is provided here: Thirion[11] on Marseille; Semenza et al.[12] on Chicago; Ballester et al.[13] with studies focused on Valencia; Dessai [14], [15] on Lisbon; Revich et al.[16] on Moscow; Hu et al. [17] on Sidney; Tan et al. [18] on Shanghai, Díaz et al. [19] on Seville, Nastos et al. [20] on Athens with special care, in this work, on the onset of respiratory disorders correlated with weather types; moreover, Yip et al. [21] considered a whole region - Maricopa County, Arizona. Johnson et al.

[22] contributed to expand the field of analysis by comparing broad geographic regions, such as England and Wales, supported by estimates on winter mortality.

Another interesting study was carried out in France by Laaidi et al.[23], who introduced analyses on a variety of environmental and climatic contexts with respect to the GW. With reference to climatic change, the $W H O$ [24] with a perspective global scenario, as well as the Ministry of Health [25] and the Higher Health Institute [26] for Italy, provided a significant input derived from the health effects produced by the heat waves recorded in 2003, later elaborated and confirmed in the light of the latest IPCCReport [27]. The consistent scientific production developed in the past decade resulted into a meta-analysis on mortality carried out by Weiwei Yu et al. [28] on publications focused on two meteo-climatic categories - winter (cold) and summer (heat) - which highlighted a closer relation with mortality in summer conditions (hot environment).

References

1. M. Vergetti (a cura di), Opere di Ippocrate (1965), Unione Tipografico-Editrice Torinese.

2. World Health Organization (1999), El Nino and Health.

3. World Health Organization (2005), Using climate to predict infectious disease epidemics.

4. Rusticucci M., Bettolli M.L. (2002), Association between weather condition and the number of patients at the emergency room in an Argentine hospital, International Journal of Biometeorology, 46:42-51. 
5. Makle T., Harada M., Kinukawa N., Tojoshiba H., Yamanaka T., Nakamura T., Sakamoto M., Nose Y. (2001). Association of meteorological factors and day of the week with emergency hospital admissions in Fukuoka, Japan ,International Journal of Biometeorology, 46:38-41.

6. Kovats S.R., Hajat S., Wilkinson P.: 2004. Contrasting patterns of mortality and hospital admissions during hot weather and heat waves in greater London, UK. Occup J Environ Med 61:893-898.

7. Besancenot J.P. (2002). Vagues de chaleur et mortalité dans les grandes agglomérations urbaines. Environ Risques Santé, $1: 229-240$.

8. Stafoggia M., Forastiere F., Agostini D., Biggeri A., Bisanti L, Cadum E., Caranci N., de' Donato F., De Lisio S., De Maria M., Michelozzi P., Miglio R., Pandolfi P., Picciotto S., Rognoni M., Russo A., Scarnato C., Perucci C.A. (2006). Vulnerability to heat-related mortality: a multi-city population-based case-crossover analysis. Epidemiology, 17:315-323 9. Curriero F.C., Heiner K.S., Samet J.M., Zeger S.L., Strug L., Patz J.A. (2002). Temperature and mortality in 11 cities of the Eastern United States, Am J Epidemiol, 155:80-87.

10. Michelozzi P., Accetta G., De Sario M., D’Ippoliti Daniela, Marino C., Baccini M., Biggeri A., Ross Andeson H., Katsouyanni K., Ballester F., Bisanti L., Cadum E., Forsberg F., Forastiere F., Goodman P.G., Hojs A., Kirchmayer U., Medina S., Paldy A., Schindler C., Sunyer J e Perucci C.A. (2009). Hight temperature and ospitalizations for cardiovascular and respiratory causes in 12 european cities. Am J. Respir. Crit. Care Med., 179:383-389.

11. Thirion X. (1992). La vague de chaleur de juillet 1983 à Marseille: enquête sur la mortalité, essai de prévention. Santé Publique, 4:58-64.

12. Semenza J.C., Rubin C.H., Falter K.H., Selanikio J.D., Flanders W.D., Howe H.L., Wilhelm J.L. (1996). Heat-related deaths during the July 1995 heat wave in Chicago. N Engl J Med 335:84-90.

13. Ballester F., Corella D., Perez-Hoyos S., Saez M, Hervas A. (1997). Mortality as a function of temperature. A study in Valencia, Spain, 1991-1993. Int J Epidemiol 26:551-561.

14. Dessai S. (2002). Heat stress and mortality in Lisbon. Part 1. Model construction and validation. International Journal Biometeorology, 47:6-12.

15. Dessai S. (2003). Heat stress and mortality in Lisbon. Part II. An assessment of the potential impacts of climate change. International Journal of Biometeorology, 48:37-44.

16. Revich B., Shaposhnilkov D. 2008: Tempertature-induced excess mortality in Moscow. Int J Biometeorol, 52: 367-374

17. Hu W., Mengersen K., Mc Michael A., Tong S., 2008: Temperature, air pollution and total mortality during summer in Sidney, 1994-2004. Int J Biometeorol, 52: 689-696.

18. Tan J., Zheng Y., Song G., Kalkstein L.S., Kalkstein A.J., Tang X.: 2007. Heat wave impacts on mortality in Shangai, 1998 and 2003, International Journal of Biometeorology, 51:193-200.

19. Diaz J., Garcia R., Velázquez de Castro F., Hernández E., López C., Otero A. (2002). Effects of extremely hot days on people older than 65 years in Seville (Spain) from 1986 to 1997. Intertanional Journal Biometeorology 46:145-149.

20. Nastos P. T.., Matzarakis A. (2006). Weather impacts on respiratory infections in Athens, Greece, International Journal of biometeorology, 50:358-369.

21. Yip F.Y., Flanders W. D., Wolkin A., Engelthaler D., Humble W., Neri A., Lewis W., Backer L., Rubin C., 2008: The impact of excess heat events in Maricopa County, Arizona: 2000-2005. Int J Biometeorol, 52: 765-772

22. Johnson H, Griffiths C., (2003) Estimating excess winter mortality in England and Wales, Health Stat Q, 20:19-24.

23. Laaidi M., Laaidi K., Besancenot JP. (2006). Temperature-related mortality in France, a comparison between regions with different climates from the perspective of global warming, 51:145-153.

24. WHO, (2003). Methods of assessing human health adaptation to climate change.

25. Ministero della Salute, (2008). Relazione sullo Stato Sanitario del Paese.

26. Istituto Superiore di Sanità, (2003). Indagine Epidemiologica sulla Mortalità Estiva.

27. IPCC, Climate Change 2007 - Impacts, Adaptation and Vulnerability Working Group II contribution to the Fourth Assessment Report.

28. Yu W., Mengersen K., Wang X., Ye X., Guo Y., Pan X., Tong S., 2012: Daily average temperature and mortality among the elderly: a meta-analisys and systematic rewiew of epidemiological evidence. Int J Biometeorol, 56:569-581 


\title{
L3 - Balneological Treatments with Natural Hydrogen Sulfide $\left(\mathrm{H}_{2} \mathrm{~S}\right)$ Waters
}

\author{
Müfit Zeki Karagülle
}

Corresponding author: Müfit Zeki Karagülle, E-mail: mzkaragulle@yahoo.com

\begin{abstract}
In balneology hydrogen sulfide $\left(\mathrm{H}_{2} \mathrm{~S}\right)$ waters are defined as natural mineral waters originally containing $\mathrm{H}_{2} \mathrm{~S}$ with an $\mathrm{S}^{2-}$ level at least $1 \mathrm{mg} / \mathrm{L}$. Their use as a specific balneological factor in health resorts medicine has a long history. Distinction between sulfur and sulfate mineral waters should also be made clearly since both terms are occasionally used interchangeable in balneological literature. Balneological waters containing at least $1200 \mathrm{mg} / \mathrm{L}$ sulfate ion $\left(\mathrm{SO}_{4}{ }^{2-}\right)$ are referred as "sulfate waters", the ones originally and naturally containing dissolved $\mathrm{H}_{2} \mathrm{~S}$ gas with an $\mathrm{S}^{2-}$ level at least $1 \mathrm{mg} / \mathrm{L}$ are traditionally named "sulfur waters".

Hydrogen sulfide water based balneological treatments are baths; "sulfur balneotherapy", drinking cures; "sulfur water hydropinic therapy", inhalations and Politzer therapies, irrigations and showers and sprays. $\mathrm{H}_{2} \mathrm{~S}$ waters are most widely used as baths and a lesser extend as drinking cures (hydropinic treatments), inhalations and irrigations. Sulfur mud therapy is another form of balneological therapeutic method with sulfur containing peloids. The main component that is playing the major therapeutic role in the observed biologic effects of balneological treatments (bathing, drinking and inhaling) with natural $\mathrm{H}_{2} \mathrm{~S}$ water is supposed to be hydrogen sulfide, since it is difficult to determine which form of $\mathrm{H}_{2} \mathrm{~S}\left(\mathrm{H}_{2} \mathrm{~S}, \mathrm{HS}^{-}\right.$or $\left.\mathrm{S}^{2-}\right)$ is active.

After the recognition of $\mathrm{H}_{2} \mathrm{~S}$ as a gaseous transmitter experimental, in vitro and in-vivo and clinical studies on the effects of $\mathrm{H}_{2} \mathrm{~S}$ water balneological treatments in various conditions in humans and animal models are being published recently, and the data is increasing continuously.

During balneotherapeutic sulfur bath applications, it has been demonstrated that hydrogen sulfide from water can be absorbed by the skin 150 times more than the other forms. $\mathrm{H}_{2} \mathrm{~S}$ afterwards may exert anti-inflammatory and immune modulator effects in skin and musculoskeletal system. It has been also shown that $\mathrm{H}_{2} \mathrm{~S}$ is easily absorbed in gastrointestinal tractus during the hydropinic treatment with $\mathrm{H}_{2} \mathrm{~S}$ waters and then playing active role in redox reactions in human body as an antioxidant. There is evidence that inhalation therapy with hydrogen sulfide waters have positive impact on the respiratory inflammatory processes adding an efficient option to the therapeutic strategy of upper and lower respiratory airways problems.

Studies evaluating the biological effects and mechanisms of action of sulfur water balneotherapy, hydropinotherapy and inhalation therapy and sulfur mud therapy in humans, in animal models of diseases and in cell cultures are reporting the biologic effects mostly similar to the physiological functions of endogenous $\mathrm{H}_{2} \mathrm{~S}$. In this report obtained data is briefly presented and discussed.
\end{abstract}




\title{
L4 - Specific advanced quantifications on the relationship between the angulation of the main
} scoliotic curve and leg swing in the gait phases, in children and adolescents with and without postural treatment

\section{As. Univ. Drd Constantin Florin Dragan ${ }^{1,2}$, Conf. Univ. dr. Liliana Padure ${ }^{1,2}$, Prof. Univ. Dr. Gelu Onose ${ }^{1,3}$}

${ }^{2}$ National Teaching Centre for Neuro-psycho-motor Rehabilitation in Children (NTCNRC) "Dr. N. Robanescu"

3 Teaching Emergency Hospital "Bagdasar-Arseni”, Bucharest, Romania

\begin{abstract}
The study was conducted in NTCNRC where many children with scoliosis are treated. We wanted to objectify the foot's contact with the support surface by using specific investigations, to study if there is a correlation between the curves and the change (deviation from normal) of the foot contact with the ground. The reason for choosing this topic was to complete a new way of assessing the patient with static vertebral disorder. The aim of the study was to present the advantages of this method that will help us to analyze the possibilities of multidisciplinary therapeutic intervention for the patient with scoliosis.

We used modern assessment and training device specialized in plantar pressure assessment, Footscan 7 gait $2^{\text {nd }}$ generation, $2 \mathrm{~m}$ plate, 16000 UNIC sensors (at the beginning of the study).

Plantar pressure represents the foot's contact with the ground, and is evaluated in our study by static and dynamic measurement with Footscan 7 gait $2^{\text {nd }}$ generation.

This study included 120 patients with scoliosis: 72 girls and 48 boys, aged between 5-18 years. All of them were assessed at the first admission, during 3 hospitalizations, from the beginning of 2013 till present.

Patients were evaluated in static and dynamic, with and without Cheneau brace (the brace recommended by the specialist doctor).

The statistical analysis was done after performing the frequency histograms related to the identification of the level of normality in population distribution, and included parametric (type $t$ ) and nonparametric (type, for example, chi2) tests for differentiation.

The statistical results showed a change in the legs' swing during the spine correction in the Cheneau brace, during the three hospitalizations, and is statistically significant for all situations.

In conclusion, there is a link between the severity of scoliosis curvature and the foot's swing on the support surface. The scoliotic curve influences the contact of the foot with the support surface: when the curvature decreases by more than 15 degrees, passively, by applying the Cheneau brace, the plantar support changes.
\end{abstract}


L5- A multimodal approaches to manage rehabilitation therapy of disfunctionals aspects to a pacient with Gout, Miellitus diabetes, Atrial Fibrilation and Middle Cerebral Artery Stroke

Irina ALBADI ${ }^{1,2, *}$, Camelia CIOBOTARU ${ }^{1,2}$, Andreea-Alexandra LUPU ${ }^{1,2}$, Ionela BALASA ${ }^{1}$, Claudiu FATU ${ }^{1}$, Enghin SACHIR ${ }^{1}$, Gelu ONOSE ${ }^{3}$

Corresponding author: Irina ALBADI irina.albadi@yahoo.com

${ }^{1}$ Spitalul Judetean de Urgenta "Sfantul Apostol Andrei” Constanta, Romania

${ }^{2}$ Universitatea "Ovidius" Constanta, Facultatea de Medicina, Romania

${ }^{3}$ Spitalul Clinic de Urgenta "Bagdasar-Arseni", RoSCoS, Universitatea de Medicină și Farmacie "Carol Davila",

RoSNeRa, București, Romania

\section{Abstract}

Introduction Stroke is a medical condition characterised as rapidly developing clinical signs of a focal or global injury of cerebral function, usually lasting more than $24 \mathrm{~h}$ or leading to death, with no apparent cause than vascular origin. (1) From the etiological point of view, stroke can be: ischaemic stroke - 80-85\% (tromboembolic source: atrial fibrillation, myocardial infarction, valvulophaties, congenital cardiac defects, atherosclerosis, coagulation factor deficiency) or hemorrhagic stroke (haematomas caused by craniocerebral trauma, broken arteriovenous malformation, thrombocythopenias, hemophilia). (2) Stroke is the second common cause of death after coronary heart disease, with approximately 60.000 strokes occurs each year in Romania. (3) Gouty Arthritis represents one of the common inflammatory arthritis, caused by uric acid crystals deposition in the tissues. The global incidence of gout has risen in the last year due to unhealthy diet, sedentary lifestyle, the problem of obesity and the presence of metabolic syndrome. (4) The recent studies indicate the association of cardiometabolic multimorbidity with stroke and myocardial infarction. $(5,6,7)$

Material and method. The authors want to bring attention to a complex case of a 58 years male patient (based on his signed inform consent), ethanol consumption, known with gout, diabetes, atrial fibrillation and right spastic hemiplegia secondary to a left middle cerebral artery stroke (MCA). The patient was admitted to our department for right ankle pain (inflammatory character), mixed aphasia, walking disorders and self-care disorders.

Results and discussions. The patient followed medical treatment (corticosteroides, analgesics, gastrointestinal protectants, lipids lowering, diuretics, beta blockers, sartans, calcium channel blockers, oral anticoagulants, neurotrophic factors and hypoglycemic agents) and rehabilitation treatment: local cryotherapy, Laser Therapy, electrotherapy, magnetotherapy, massage therapy and individual kinesiotherapy. The evolution was positive with arthritis remission and improvement of motor deficit.

Conclusions. The specify of our case is a patient under sixty years old (not an older person) with polypathology (stroke, gout, diabetes, permanent atrial fibrillation), characteristic of the elderly. (8) Also it is importance to notice an appropriate risk management in cardiovascular and cerebrovascular diseases in pacients with gout.

Key words: stroke, gout, rehabilitation, diabetes.

Refferences:

1. Hatano S. Experience from a multicentre stroke register: a preliminary report. Bull World Health Organ. 1976;54(5):54153.

2. Gelu Onose si Liliana Padure (editori coordonatori) si col. - Compendiu de Neuroreabilitare la adulti, copii si varstnici Editura Universitara "Carol Davila", Bucuresti, 2008

3. King's College London for the Stroke Alliance for Europe - The Burden of Stroke in Europe / Romania

4. Gaafar Ragab, ${ }^{\mathrm{a}, *}$ Mohsen Elshahaly, ${ }^{\mathrm{b}}$ and Thomas Bardin ${ }^{\mathrm{c}}$ - Gout: An old disease in new perspective - A reviewJ Adv Res. 2017 Sep; 8(5): 495-511. Published online 2017 May 10. doi: 10.1016/j.jare.2017.04.008

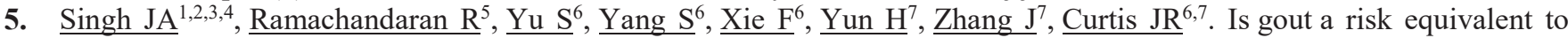
diabetes for stroke and myocardial infarction? A retrospective claims database study. Arthritis Res Ther. 2017 Oct 17;19(1):228. doi: 10.1186/s13075-017-1427-5.

6. Seminog $\mathrm{OO}^{1}$, Goldacre MJ.-Gout as a risk factor for myocardial infarction and stroke in England: evidence from record linkage studies.- Rheumatology (Oxford). 2013 Dec;52(12):2251-9. doi: 10.1093/rheumatology/ket293. Epub 2013 Sep 17.

7. JAMA. 2015 July 7; 314(1): 52-60. doi:10.1001/jama.2015.7008.

8. https://www.who.int/healthinfo/survey/ageingdefnolder/en/ 


\title{
L6 - Prevention Considerations in Cardiovascular Diseases regarding the premature mortality reduction
}

\author{
Elena Raevschi
}

Corresponding author: Elena Raevschi, E-mail: elenaraevschi@usmf.md,

Abstract

Nicolae Testemitanu State University of Medicine and Pharmacy, Chisinau, Republic of Moldova

Introduction. Cardiovascular diseases are recognized as worldwide (1) and national public health issue (2, 3 ). This is argued by having a leading position in the structure of general mortality and disability, the substantial loss of quality of life and the health system needs for increased costs. Prevention and control of cardiovascular disease has become one of the priority directions for global and national noncommunicable disease control strategies developed to reduce premature mortality $(1,4)$. The major cardiovascular diseases mortality was identified some aspects of premature mortality among the adult population in the Republic of Moldova. Overall decrease of mortality due to cardiovascular diseases among adults $(-5.9 \%)$ has been accompanied by a relatively slower decrease in premature mortality $(-2.4 \%)$ in the Republic of Moldova (5). Primary, secondary and tertiary prevention measures are essential in reducing the burden of cardiovascular disease and contribute to improving cardiovascular health at the population level. Nature is helping people to maintain their health through mechanisms much closer to them than pharmaceutical ones through the curative action of the various natural factors that form the climate of the respective territorial area.

Material and method. There is a descriptive study based on statistical data of the World Health Organization and official vital statistics of the Republic of Moldova.

Results and discussions. The climatic conditions of Moldova are favorable to cardiovascular prevention and rehabilitation. Moldova is located in the temperate continental climate influenced by the proximity of the Black Sea and the interference of warm-humid air from the Mediterranean. The annual air temperatures average in the country is $9,3^{\circ} \mathrm{C}$. In the Republic of Moldova the warm weather with a confortable temperature lasts 175 days and the relative humidity oscillates in the average from 66 to $87 \%$. The country's thermal regime is the most important curative factor for treating chronic diseases and opportunity for the amplification of medical rehabilitation programs for patients with cardiovascular diseases. Application of methods based on the action of climatic factors in cardiovascular rehabilitation process contributes to its efficiency. Increasing the role of tertiary prevention is a good practice for the quality improvement of medical services for this category of patients. By making appropriate, timely and complex measures of primary, secondary and tertiary prevention cardiovascular disease can be substantially prevented.

Conclusions. Strengthening cardiovascular prevention centered on a complex approach to all its primary, secondary, and tertiary components is an opportunity to reduce premature mortality in the population.

Key words: Cardiovascular diseases, prevention, premature mortality

\section{References}

1. World Health Organization. Global action plan for the prevention and control of noncommunicable diseases 20132020. Geneva, 2013. http://apps.who.int/iris/bitstream/10665/94384/1/9789241506236 eng.pdf

2. Programul naţional de prevenire şi control al bolilor cardiovasculare pentru anii 2014-2020. Hotărârea Guvernului nr. 300 din 24 aprilie 2014. În: Monitorul Oficial al Republicii Moldova, 06.05.2014, nr.104-109, art. Nr:327. http://lex.justice.md/index.php?action=view\&view=doc\&lang=1\&id=352739 (vizitat 27.10.2016).

3. Strategia naţională de prevenire şi control al bolilor netransmisibile pe anii 2012-2020. Hotărîrea Parlamentului nr. 82 din 12 aprilie2012. În: Monitorul Oficial al Republicii Moldova, 22.06.2012, nr.126-129, art. Nr:412. http://lex.justice.md/index.php?action=view\&view=doc\&lang=1\&id=343682 (vizitat 27.10.2017).

4. Strategia națională de sănătate publică pentru anii 2014-2020. Hotărârea Guvernului nr. 1032 din 20 decembrie 2013. În: Monitorul Oficial al Republicii Moldova, 27.12.2013, nr.304-310, art. Nr:1139. http://lex.justice.md/index.php?action=view\&view=doc\&lang=1\&id=350833 (vizitat 04.03.2018).

5. Raevschi E. Mortalitatea cardiovasculară prematură în Republica Moldova. Chișinău: Elan Poligraf, 2017. 162 p. 


\title{
L7 - The effectiveness of the rehabilitation programme according to the etiopathogenesis of prosthetic joint pathology
}

\section{Anişoara Cimil}

\begin{abstract}
Introduction: The effectiveness of the rehabilitation programme applied to the patients in the process of recovery suffering from hip arthroplasty in the study was estimated to be differentiated according to the etiopathogenesis of prosthetic joint pathology: degenerative, posttraumatic or dysplastic.

Materials and Methods: The study is based on clinical and statistical analysis in the Rehabilitation Department of the Traumatology and Orthopedic Hospital on the analysis of the effectiveness of the medical rehabilitation during the years 2017-2018 and evaluated in 129 patients after hip arthroplasty of various etiopathogenesis estimated by the prism dynamics of locomotor functionalities and scales, such as Harris DAbinie, QOL.

Results: The efficacy of the treatment was appreciated by the beneficiaries of the recovery from the perspective of the functional parameters dynamics, such as Harris, D*Abinie, QOL. The statistically analysed resultant indices differ between the estimated lots in favour of the group that benefited from the recovery algorithm applied according to the etiopathogenesis of the coxopathy. Also, the control group had a significantly lower Harris $(\mathrm{P}=0,006), \mathrm{D}^{*}$ Abinie $(\mathrm{P}=0,009)$, QOL $(\mathrm{P}=0,0045)$ than the group who received algorithm the treatment according to the etiopathogenesis of prosthetic joint pathology.

Conclusions: Overall, the results of the research confirm that effectiveness medical rehabilitation depended on the individualized rehabilitation programm for each ethiopatologic groups of patients, was demonstrated to be achievable through prism Key Functional Parameters.
\end{abstract}

Key words: rehabilitation, degenerative, dysplastic and posttraumatic coxartrosis, quality of life. 


\title{
L8 - FOURTH INDUSTRIAL REVOLUTION (INDUSTRY 4.0) AND MODERN THERMAL MEDICINE (THERMAE 4.0) IN XXI ${ }^{\text {st }}$ CENTURY
}

\author{
Traian -Virgiliu SURDU ${ }^{1}$, Monica SURDU² Olga SURDU ${ }^{3}$
}

Corresponding author: Traian - Virgiliu Surdu $\underline{\operatorname{traian} @ \text { surdu.ro }}$

${ }^{1}$ Ovidius University Constanta, Faculty of Medicine:

${ }^{2}$ Constanta County Emergency Clinical Hospital "St. Apostle Andrew":

${ }^{3}$ Balneal and Rehabilitation Sanatorium Techirghiol

\begin{abstract}

\section{Introduction}

We are now on the eve of the fourth industrial revolution (4.0) and modern medicine including thermal medicine fully benefits of the scientific and technological progress. Are we prepared to apply all achievements? Are we able to teach our students new methods?

The aim of this paper work is to open a discussion on the huge impact of fourth industrial revolution in balneology in order to create a real thermae 4.0

\section{Matherials and methods}

Articles and notes from World Economic Forum (WEF) and other international meetings, legislation, regulation for health, health education and environment

\section{Results and discussions}

The Fourth Industrial Revolution is characterized by "a fusion of technologies that is blurring the lines between the physical, digital, and biological spheres, collectively known as cyber-physical systems" It refers to the sheer volume of technological advance that is already disrupting all aspects of civil society including government, health care, education, employability, the urban experience and more. Such transformation requires a holistic approach that encompasses innovative and sustainable system solutions and not just technological ones. The WEF response to the Fourth Industrial Revolution was the creation of Centre for The Fourth Industrial Revolution in 2017 at Fort Scott. Among other topics "The Precision Medicine" - aims to support the building and testing of policy frameworks to realize the benefits of precision medicine for society, while reducing risks. It offers the opportunity to harness emerging technologies to tailor diagnosis and treatment of disease to a specific person or population, improving outcomes and potentially lowering costs. Project areas include: generating evidence of precision medicine's effectiveness, data-sharing and related infrastructure, integrating a precision medicine approach into clinical practice, new approaches to regulation, pricing and reimbursement for diagnostics and treatment, patient and public engagement. Nowadays robotics, artificial intelligence, virtual reality are present in the in balneal rehabilitation.
\end{abstract}

\section{Conclusion}

The scale, scope and complexity of how technological revolution influence our behaviour and way of living will be unlike anything humankind has experienced. In this amazing context Thermae 4.0 is real.

\section{References}

1. Klaus Schwab, Founder and Executive Chairman of the World Economic Forum, 2016.

2. Response to the Presidio Trust's Request for Concept Proposals at Fort Scott june 2018:

3. Kenneth Baker - "The impact of the Fourth Industrial Revolution on Employment and Education" 2016 EDGE Foundation 


\title{
L9 - Effects of carbonated mineral water and mofette in Băile Tuşnad in experimentally induced ischemic heart disease
}

Gabriela DOGARU ${ }^{1}$, Akos MOLNAR ${ }^{2}$, Marieta MOTRICALA ${ }^{2}$, Constantin MUNTEANU ${ }^{3}$, Adriana BULBOACA ${ }^{1}$

Corresponding author: Gabriela DOGARU, Email: dogarugabrielaumf@gmail.com

\section{(cc) BY-NC-ND} Balneo Research Journal DOI: http://dx.doi.org/10.12680/balneo.2019.276

1. Clinical Rehabilitation Hospital, "Iuliu Haţieganu" University of Medicine and Pharmacy, Cluj-Napoca, Romania 2. Tuşnad Spa Complex SA, Băile Tuşnad, Romania 3. Romanian Association of Balneology, Bucharest, Romania

\begin{abstract}

\section{Introduction}

Mofette and mixed carbonated natural mineral waters in Băile Tuşnad, which are used for external treatment in individual tubs or in pools, are indicated for the prevention and therapy of cardiovascular patients.

Objectives

To assess the efficacy of natural therapeutic factors with the aim of continuing the rehabilitation treatment of patients with stable chronic coronary disease in a spa and climatic resort for cardiovascular diseases.

Material and method

An experimental study was conducted on Wistar rats, divided into 6 groups. Ischemic heart disease was induced using isoproterenol. Some animals swam in tap water for two weeks, while others swam in carbonated mineral water, and a group was exposed to mofette. Blood was collected in order to determine oxidative stress markers, i.e. reactive oxygen metabolites, and total antioxidant status. Following euthanasia, myocardial tissue samples were collected for microscopic examination. The study was approved by the Ethics Committee of the University of Medicine and Pharmacy Cluj-Napoca.

Results

After two weeks, changes in oxidative stress markers, as well as biological effects on the heart were observed by optical microscopic structural studies of the carbonated mineral water and mofette in ischemic heart disease induced experimentally in Wistar rats.

\section{Conclusions}

Carbonated natural mineral baths and exposure to mofette can be an effective therapeutic method for the treatment of cardiovascular diseases such as chronic coronary disease. However, it is important to periodically analyze their physical and chemical properties, and subsequent clinical studies regarding their therapeutic efficacy and mechanism of action are required.
\end{abstract}




\title{
L10 - Therapeutic difficulties in a young patient with multidrug resistant epilepsy (needing vagal nerve electrostimulation), sequelae after congenital vascular cerebral malformation, with chronic gait impairments and recent traumatic brain complication
}

\author{
Aurelian Anghelescu ${ }^{1,2}$, Valentin Deaconu $^{1}$, Axente Catalina $^{1}$, Elena Constantin ${ }^{1}$, Gelu Onose $^{1,2}$
}

Corresponding author: aurelian anghelescu@yahoo.co.uk

\section{Introduction}

Focal epilepsy (possible with secondary generalization) may be a complication secondary to any brain damage (traumatic, vascular, infectious lesions), and is characterized by abnormal excessive neuronal activity with motor, cognitive and psychosocial manifestations. About one third of patients who suffer from epilepsy have refractory epilepsy. Falls are one of the most common medical complications in neurologic patients, occurring during paroxysmal epileptic attacks, or due to sequelary gait limitations. Physical injuries are common at patients with epilepsy, about $47 \%$ report having at least one injury in the past 12 months.

Case presentation. We present a 36-years-old male patient with a medical history of right frontal congenital arteriovenous malformation, ruptured and operated at the age of eight, complicated with left spastic hemiplegia and refractory epilepsy, needing three antiepileptic drugs (AED) and vagus nerve-stimulation (VNS).The case presentation was approved by THEBA Bioethics Committee (No.17464/14.06.2019). During a recent epileptic seizure he suffered a traumatic brain injury, coma (GCS 5), needing intensive care supervision, and orotracheal intubation. CT scan revealed right hemispheric subdural hematoma operated (on the $2^{\text {nd }}$ May 2019). Rebleeding occurred seven days later, due to an extradural hematoma. Emergency surgical reintervention was performed. The patient was transferred in our neurorehabilitation clinic with left spastic hemiplegia (global motor score 65/100, FIM/ functional independence measure 24/91, upper limb spasticity 1+, lower limb 2 on the modified Ashworth scale). Neuropsychological assessment revealed an obtunded level of consciousness, depression and dysmnesia for recent events, MMSE 9/30. During hospitalization the patient has continued his previous daily treatment with AED: levetiracetamum $2000 \mathrm{mg}+$ clonazepamum $1 \mathrm{mg}+$ carbamazepinum retard (timonil) $600 \mathrm{mg}$, associated with VNS. During hospitalization emerged three short jacksonian seizures, who gave up spontaneously. The overall evolution was favorable with rehabilitation program and psychological support, with improvement of the global motor score, FIM 44/91, and partial restoration of walking ability on small distances, still needing human help.

Discussion. Relapse of seizures imposed pathophysiological analysis: imbalance of the local brain metabolism and /or a dysfunctional VNS procedure (due to an impaired electronic device or a local fibrosis and increased impedance at the contact level between the electrode and the vagal nerve). Specialized technical control disclosed normal electric parameters provided by the electronic device. Other neuromodulatory devices and related technologies such as deep brain stimulation (DBS) immediately demonstrate their effect control (motor correction) of Parkinson's or dystonic movements. Unfortunately VNS has not this feed-back control effect. The immediate quod ad vitam prognosis is unfavorable, because epileptic seizures can relapse anytime and evolution is uncontrolled. The AED schedule was modified, adding $1 \mathrm{mg}$ of clonazepamum. Video-EEG monitoring was recommended. Furthermore, the new brain injures may exacerbate the severity of the epilepsy, any new seizure may worsen the neurologic evolution. The rehabilitation quod ad functionem outcome might be also precarious. The family support is essential in the therapeutic efforts. This clinical case underlines the importance of prophylaxis of falls in patients with epilepsy, the importance of therapeutically adaptation of medication at different pathophysiological stages of the disease, and limits of the modern neuromodulation techniques to control seizures.

References

1. Asadi-Pooya AA, A Nikseresht, E Yaghoubi, M Nei (2012), Physical injuries in patients with epilepsy and their associated risk factors, Seizure 21 (3), 165-168

2. Anghelescu A (2017) Clinical and Pathophysiological Considerations of Gait Limitations and High Prevalence of Falls, in Elderly with Most Common, Disabling Neurological Diseases. Int J Neurorehabilitation 4:262. doi:10.4172/2376-0281.1000262

3. Liporace J, D Hucko, R Morrow, G Barolat, M Nei, J Schnur, M Sperling, (2001) Vagal nerve stimulation: adjustments to reduce painful side effects, Neurology 57 (5), 885-886.

4. Pillai J, M Nei, A Zangaladze, A Sharan, C Comer, M Sperling Is vagus nerve stimulation effective after failed epilepsy surgery? (2005), Epilepsia 46 
L11 - Diagnostic particularities and multimodal therapeutic and rehabilitation approaches to a complex case of post ischemic stroke with dysphagia and dysphonia, associating Millard-Gubler and Wallenberg syndromes - case report

Luminița Nirlu*1, Alexandru G. Stavrică ${ }^{1}$ Laura Georgiana Popescu $^{1}$, Ana Carmen Albeșteanu ${ }^{1}$, Ali-Osman Saglam ${ }^{1}$, Gelu Onose ${ }^{1,2}$

Corresponding author: Luminița Nirlu, e-mail: nirluluminita@gmail.com

${ }^{1}$ Neurorehabilitation Clinic, Teaching Emergency Hospital „Bagdasar-Arseni” (TEHBA), Bucharest, Romania 2 "Carol Davila" University of Medicine and Pharmacy, Bucharest, Romania

\begin{abstract}

\section{Introduction}

Millard-Gubler syndrome (MGS), also known as the ventral pontine syndrome or hemiplegic syndrome, is one of the classical crossed syndromes characterized by a unilateral lession of the basal portion of the caudal part of the pons. MGS manifests as ipsilateral palsy of CN VI and VII with contralateral hemiplegia.

Wallenberg syndrome or lateral medullary syndrome, is characterized by the triad of Horner's syndrome, ipsilateral ataxia and contralateral hypoalgesia. Other clinical symptoms may include difficult swallowing, slurred speech, vertigo, nausea, vomiting, dyspnea, tachycardia, headaches and muscular hypertonia.
\end{abstract}

\title{
Materials and Methods
}

Having the patient's consent and The Teaching Emegency Hospital "Bagdasar-Arseni" Ethics Committeee N.O 20270 from the 26th of June 2019, the current case report presents a 67-year-old male patient from rural area with left hemiplegia (complete brachial and crural motor deficit), right eye abduction paresis, dysphagia, dysphonia, central facial palsy - all post acute ischemic stroke. The patient was also diagnosed with ischemic cardiomyopathy, atherosclerosis, alcoholism, Type 2 diabetes with Insulin therapy and oral antidiabetic agent. The patient was admitted in the Neurorehabilitation Clinic of the Teaching Emergency Hospital „BagdasarArseni" (TEHBA) Bucharest, Romania, associating severe alteration in self-care abilities, locomotor dysfunction, memory disorders, slurred speech, for specialized rehabilitation treatment and nursing.

\section{Results.}

A case of rare pathology for which unfortunately there is a discrepancy between functional improvement and the poor motor control in the in the lower limbs (muscle force was 0-1out of 5 on the Medicale Research Council scale), within an overall favorable evolution, including elements of the clinical status afferent to the two above mentioned syndromes.

\section{Conclusions}

Approaching such a clinical case has been a complex and extensive challenge for the entire neuromuscular recovery team and remains similar for any other squad. This pathology remains an issue that demands our earnest attention.

Key words: Millard-Gubler syndrome (MGS), Wallenberg syndrome, crossed syndromes, hemiplegia, neurorehabilitation, stroke. 


\title{
L12 - Ionophoresis and LASER applications in facial nerve palsy
}

Cristina Octaviana DAIA ${ }^{1,2}, \underline{\text { Stefana CROITORU }}^{1}$, Mariana AXENTE ${ }^{1}$, Gelu ONOSE $^{1,2}$

Corresponding author: Croitoru Stefana: stefana croitoru@yahoo.com

\begin{abstract}

\section{Background and aim of the study}

The aim of this article is to present the functional gain of the specific rehabilitation program in patients with facial nerve paralysis, irrespective of etiology, following a complex physiotherapeutic treatment, consisting of the combined application of ionophoresis and LASER.

\section{Material and Method}

We performed a retrospective analysis of 26 patients having their consent and The Theaching Emergency Hospital "Bagdasar-Arseni" (TEHBA) ethics Comitte's approval, N.O. 683/21.02.2019. The patients were admitted to the Neuro-Muscular Rehabilitation Clinic Division of TEHBA between April 2011 and March 2019. The patients were over the age of 18 , diagnosed with facial nerve palsy and received physiotherapy consisting of the combined application of: ionophoresis with $1 \%$ potassium iodide, applied to positive electrode, preauricular, and the negative electrode, retroauricular, for 20 minutes and LASER, to the temporomandibular joint on the affected part, 4 points : radiant exposure per dose $3 \mathrm{~J} / \mathrm{cm}^{2}$, frequency $5 \mathrm{~Hz}$, probe area $1 \mathrm{~cm}^{2}$, power $62 \mathrm{~mW}$, for 10 sessions and two sets of the same formula at the temporomandibular joint on the opposite side.

\section{Results}

From the etiological point of view, the study included an equal number of patients with peripheric facial palsy (PFP) and with central facial palsy (CFP), respectively 13 in each group. Overall, at least 1 patient in 2 had a positive response to physiotherapy. In the patients with PFP, $77 \%$ of patients responded to the treatment and $46 \%$ had complete remission. In the patients with CFP, only 30\% responded to treatment and only one had complete remission. Approximately half of the patients did not have any adverse reactions (46\%), while the rest showed temporary erythema (46\%), or local tingling sensation over a variable period of time (8\%).
\end{abstract}

\section{Conclusion}

Applying the combination of ionophoresis and LASER as physiotherapic treatment is particularly effective in peripheric facial nerve paresis. The method is safe and well tolerated, therefore we propose its use in this type of pathology. 


\title{
L13 - Splinting versus surgical treatment in Mallet finger
}

\author{
Doina Maria MOLDOVAN', Gabriela DOGARU²
}

Corresponding author: Doina Maria Moldovan, E-mail: ortoped687@gmail.com

2. "Iuliu Hatieganu" University of Medicine and Pharmacy, Clinical Rehabilitation Hospital Cluj-Napoca

\begin{abstract}
Introduction: Mallet finger is an extensor tendon injury consisting in tendon insertion rupture or a bony avulsion at the distal interphalangeal joint (DIP joint). Treatment of Mallet finger is controversial. The aim of this study is to follow the trend in the treatment of Mallet finger.

Materials and Methods: Using the database of PubMed, Medscape and Scopus I've found in medical literature a number of 19 studies regarding this subject, of what 4 were published before the year 2000 and 15 of them between the years 2012-2019. I've used only the articles published in English language.

Results: The treatment options differed. Most Mallet finger injuries can be solved non-surgically in both cases (soft tissue Mallet finger, as well as bony Mallet finger). The majority of the authors sustained the surgical treatment, but only in cases of opened fractures, unsuccessful splinting and in avulsion fractures when the fragment is bigger than $1 / 3$ of the joint surface and is more than $2 \mathrm{~mm}$ of displacement or is volar subluxation of the distal phalanx which is not reducible in a splint. All the authors agreed with the idea that the DIP joint has to be immobilized in extension or a slight hyperextension of approximately 25 degrees and the proximal interphalangeal joint (PIP joint) in small flexion for 6-8 weeks. If, in this period the immobilization slightly changes position, this needs to be taken up for another 6-8 weeks (from that moment on) with the DIP joint repositioned in slight hyperflexion. Other authors recommended K-wire pinning in the closed Mallet fractures with avulsion as a primary option for treatment, although it seems there is no difference in healing between the two methods (splinting and K-wire pinning).

Conclusion: The choice of treatment method in Mallet finger depends very much on the type of injury (acute or chronic, closed or opened, bony Mallet finger or soft tissue Mallet finger, and on the presence or absence of the DIP dorsal subluxation), the hospital's protocol and on the surgeon's experience.
\end{abstract}

Keywords: Mallet finger, bony Mallet finger, soft tissue Mallet finger, extensor tendon disruption, distal phalanx fracture. 
L14 - Early rehabilitation in patient after treatment for distal radius fracture

Doina Maria MOLDOVAN', Gabriela DOGARU²

Corresponding author: Doina Maria Moldovan, E-mail: ortoped687@gmail.com

1. Orthopedic and Traumatology Clinic Division, Tg-Mures

2. "Iuliu Hatieganu" University of Medicine and Pharmacy Cluj-Napoca, Clinical Rehabilitation Hospital Cluj-Napoca

\begin{abstract}
Introduction: Distal radius fracture represents 25\% from the total of fractures treated in the emergency room with an increased incidence in children between 5-14 years, men under 50 years and most women over 60 years. If in young men the traumatic nature of the fracture is noted, in women we can talk about postmenopausal osteoporosis.

Material and methods: The search in the PubMed, Medscape and Scopus database identified in the available literature a number of 10 articles published during the period 2014-2019, regarding the recovering patients after treatment for distal radius fracture (DRF). The studies included in total 543 patients with DRF on whom were performed non-surgical or surgical methods (cast for 6 weeks, close reduction- pinning with K-wire, and open reduction with internal fixation- ORIF). Patients with arthroscopic treatment of DRF were excluded from these studies, as well as children.

Results: Treatment of distal radius fractures (DRF) is different depending on the age of the patient, type of fracture, bone density and on the available materials. Therefore, a simple extra-articular non-comminuted fracture is suitable for a conservative treatment (cast splinting for 6 weeks) while one intra-articular fracture needs an open reduction and internal fixation with a volar/dorsal locking plate. Recovery after non-surgical or surgical treatment of DRF follows the same parameters for all types of fracture: decrease in pain, increasing the grip strength and improving range of motion (ROM) in the wrist joint. The starting point of recovery is different from one type of surgery to another. If, in case of conservative treatment the recovery in wrist joint starts after the removal of cast splinting ( 6 weeks post-fracture) in case of open reduction and internal fixation with volar locked plate, the recovery starts from the first week post-surgery. Ideally it would be for all the patients to be followed-up and evaluated at 2 weeks, 4 weeks, 6 weeks, 3 months, 6 months, 9 months and 1 year by measuring the grip strength and ROM in wrist (flexion, extension, pronation, supination, radial deviation, ulnar deviation).

Conclusion: The rehabilitation after DRF treatment must begin as early as standard protocols, and the patient's further observation and evaluation to be done periodically at least up to one year.
\end{abstract}

Key words: treatment of distal radius fracture, rehabilitation after distal radius fracture 
L15 - The impact of multifactorial gait analysis on the diagnosis and rehabilitation of children with walking disorders

\author{
Liliana PADURE ${ }^{1,2}$, Raluca PETCU ${ }^{3}$, Anca Irina GRIGORIU ${ }^{1 *}$
}

Corresponding author: Anca Irina Grigoriu, Email: an ir ra@yahoo.fr

1. "Dr. Nicolae Robanescu” National Neurological Rehabilitation Center for Children, Bucharest

2. UMF “Carol Davila”, Bucharest

3. Municipal Hospital of Turnu Magurele

\title{
Abstract
}

Introduction: The Multifactorial Motion Analysis is instrumental method of evaluation of the body's motion on the basis of a biomechanical model. We aimed a descriptive retrospective study of the population of children recorded in the Gait Lab in order to highlight the benefits and applications in clinical problems.

Material and Methods: 677 patients with age between 1 and 19 years and with different gait problems were evaluated in our Gait Lab from February 2015 to December 2018. The Gait Lab provides information about the spatial and temporal parameters of the gait, the 3D kinematics of the lower limbs during gait, the kinetics (ground reaction forces, joints' moments and powers) and the dynamic muscular activation, using an infrared cameras system, a force plate and an EMG wireless surface system.

Results and discussions: Among the 677 patients, 56.8\% were children with cerebral palsy, 17.8\% children with gait problems of orthopedic origin, $9.6 \%$ peripheral neuropathies and muscular diseases, $4.9 \%$ posttrauma neurological status (brain or medullar injuries), 10.9\% other gait disorders. All these data provided by the gait analysis, considered into a clinical examination, helped us to understand and quantify the gait disorders and to ensure a correct multidisciplinary management of the therapeutic recommendations. It helped us to define precisely the targets in physical rehabilitation process, to indicate and adapt the most suitable walking orthotics (66.4\% patients), choosing the targeted muscles for the botulinum toxin injection protocol in order to improve function (65.4\%), directing the most suitable type of orthopedic interventions (29.6\%). The Gait Analysis was repeated for $9 \%$ of patients in this period, showing the functional benefits of the treatment and following up the evolution of gait problems in children during growth period.

Conclusions: The Multifactorial Gait Analysis is a very important and accurate method of evaluation of gait disorders, with a major role in the multidisciplinary therapeutic approach of neurological and orthopedic pathology in children.

Keywords: $3 D$ gait analysis, children, 


\title{
L16 - REHABILITATION POSSIBILITIES OF APHASIC PATIENT
}

\author{
Valerica Creanga-Zarnescu ${ }^{1}$, Ana-Maria Fatu ${ }^{1}$, Mihaela Lungu ${ }^{2}$, Violeta Sapira ${ }^{2}$, \\ Anamaria Ciubara ${ }^{3}$
}

Corresponding author: Valerica Creanga-Zarnescu, Email: zarnescu vally@yahoo.com

1 Faculty of Medicine and Farmacy "Dunarea de Jos" University of Galati, Galati, Romania 2Neurological Department, Clinical Emergency Hospital, "Dunarea de Jos" University, Galati, Romania 3Neurological Department of Psychiaty, "Dunarea de Jos", Galati, Romania.

\begin{abstract}
Introduction:

Aphasia is a language disorder which occurs in up to $38 \%$ of stroke survivors, often leaving them with lifelong residual deficits. The most common cause of aphasia is a stroke affecting the left cerebral hemisphere.
\end{abstract}

\section{Material and method:}

The first step in the management of aphasia requires the initial diagnosis of the disorder. In the simplest classification, aphasia is divided into two main categories: motor aphasia (expressive aphasia) and sensory aphasia (receptive aphasia). Speech pathologists are typically responsible for diagnosis of aphasia resulting from stroke. A first issue that is to be clarified is that of the importance they have in treating aphasics, in therapeutic intervention and spontaneous recovery.

The treatment of aphasic patients combines psychotherapeutic methods with semantico-syntagmatic methods, this summing speech-language therapy (SLP). It is very important that the therapist adapts the rehabilitation program to the patient and their comorbidities. Several studies have shown that it is not necessary to intervene intensively in the first three weeks after the stroke, but, recently, Cochrane reviews have made significant strides toward establishing SLT as effective, supporting the neuroplasticity process. Besides the SLP, another therapeutic method accepted for severe non-fluent aphasia is melodic intonation therapy (MIT)- a treatment that uses the musical elements of speech. We have found little evidence that patients were more likely to have improved on any language measure at the end of the trial if they had received treatment with piracetam, donepezil or memantine. Another noninvasive technique based is repetitive transcranial magnetic stimulation (rTMS), it should be implemented in aphasia rehabilitation program for subacute post-stroke patients. Reduction of the excitabilityof the right peri-sylvian area in a non-fluent aphasia can lead to significant improvements. At the turn of this century, a new form of non-invasive brain stimulation emerged in the field of stroke recovery: transcranial direct current stimulation (tDCS). It has been explored in stroke rehabilitation as a method for encouraging brain plasticity, with results often lasting beyond the initial period of stimulation. tDCS also has the advantage of being portable, with built-in remote control, making it suitable for clinical experimentation during behavioral therapies.In addition to the therapies mentioned, acupuncture ("XingnaoKaiyin acupuncture") is effective in improving functional communication in post-stroke. We must not forget that language and movement are interrelated, designing the recovery program according to the handarm-languageparadigm can favorably influence the recovery of the aphasia.

\section{Conclusion:}

Aphasia is sometimes more invalidating than the motor or sensory deficiency and the team consisting of rehabilitation medicine specialist, neurologist, speech-therapist and physiotherapist should adapt the growing knowledge into clinical practice. 


\title{
L17 - Favorable rehabilitation results on a patient with severe left hemiplegia after an intraparenchymal hematoma
}

\section{Cristina DAIA $^{1,2}$, Simona SCHEK ${ }^{1}$, Stefana CROITORU ${ }^{1}$, Alina GHERGHICEANU ${ }^{1}$, Gelu ONOSE ${ }^{1,2}$}

Corresponding author: Cristina DAIA, Email: cristdaia@yahoo.com

DOI: http://dx.doi.org/10.12680/balneo.2019.276 OP Vol.10, No.3, September 2019

${ }^{1}$ Teaching Emergency Hospital „Bagdasar-Arseni” Bucharest (TEHBA)

${ }^{2}$ University of Medicine and Pharmacy "Carol Davila" in Bucharest, Romania

\begin{abstract}

\section{Introduction}

The incidence of mortality after hemorrhagic stroke on patients with different oral anticoagulants is maintained elevated at almost $30 \%$, no matter non-vitamin $\mathrm{K}$ antagonist oral anticoagulant (NOAC) or vitamin $\mathrm{K}$ antagonist (VKA) is the treatment chosen (1). The presence of hemorrhagic stroke is about $10 \%$ to $20 \%$ of all strokes and is associated with greater morbidity and mortality than ischemic strokes (2). In this state of the art, having the patient consent and the approval of the Ethics Committee of "Bagdasar-Arseni" Clinical Emergency Hospital, N.O. 17464/14.06.2019, this presentation's aim is to emphasize a successful therapeutically and rehabilitation approach on a patient with severe left hemiplegia after an intraparenchymal hematoma (IC).
\end{abstract}

\section{Case presentation}

A 75-year-old woman from the urban area, with complex prior pathologies: atrial fibrillation, hypertension, disc hernia operated, with VKA medication, suffered in 2014 an intracerebral haemorrhage (IC) and a severe left hemiplegia. The patient is admitted on 15 of December 2014, at Teaching Emergency Hospital BagdasarArseni, TEHBA, in our Neuro- Rehabilitation Clinic Division with severe left hemiplegia after a large IC. As a result of the complex therapeutic management of the neurorehabilitation program, the patient's evolution is favourable and the motor deficit become light on 13 of March 2015. Between 2015 and 2019, the patient followed several annual rehabilitation programs and is now an independent walking person.

\section{Conclusion}

The rehabilitation program including neuroprotection is a key approach of a consistent rehabilitation program after IC stroke. The positive results obtained are due to an active multidisciplinary team comprising medical doctor, kinesiotherapist, physiotherapy nurse, psychologist and also family.

Key words: hemiplegia, intraparenchymal haematoma, neuroprotection,

\section{References:}

1) Wilson D, Seiffge D, Traenka T, Basir G, Purrucker J et al. Outcome of intracerebral hemorrhage associated with different oral anticoagulants, Neurology. 2017;88(18): 1693-1700.

2) Garg R, Biller J Recent advances in spontaneous intracerebral hemorrhage Version 1. F1000Res. 2019; 8: F1000 Faculty Rev-302. PMCID: PMC6426087 
L18 - The role of therapeutic swimming in the prophylaxis of scoliosis in the " $C$ " left in children during the prepubertal period

\author{
Elena VIZITIU ${ }^{1}$, Mihai CONSTANTINESCU ${ }^{1}$, Sînziana Călina SILIȘTEANU ${ }^{1,2}$
}

Corresponding author: Sinziana Silisteanu, E-mail address: sinzi silisteanu@yahoo.com

${ }^{1}$ Kinetic therapist - "Stefan cel Mare" University of Suceava 1,2 "Stefan cel Mare" University of Suceava FEFS-DSDU, Railway Hospital Iasi - Specialty Ambulatory of Suceava

\begin{abstract}
Introduction. In the prepubertal period, structural and functional mismatches are recorded, with changes in the bone structure and poor muscle development. There are also changes in the development with the emergence of growth disorders, causing postural deficiencies but also affecting the functions of the cardiovascular, respiratory, digestive and nervous system. One of the most serious deficiencies is scoliosis characterized by postural deficiency and muscular hypotonia.

The aim of the research is to select the most effective means of therapeutic swimming in order to prevent scoliosis in the "C" left in children in the prepubertal period.

Materials and methods. The study evaluated the factors involved in the scoliosis emergence and analyzed somatoscopically and somatofunctionally children in the prepubertal age group who have a tendency to install wrong posture attitudes, namely the scoliosis left in $\mathrm{C}$, which is the most common. A number of 23 children aged 8-11 who could not swim were surveyed. The children were divided into two groups: the group 1, consisting of 12 children to whom were applied kinetic means and also dry - kinetic therapy, and the group 2 of 11 children, to whom were additionally applied therapeutic swimming methods in order to maintain an optimal morpho-functional status. Thus, the waist, the weight, the body weight index, the fingers-soil index and the lateral inclination index were assessed. The functional indicators were also assessed: respiratory and cardiac frequency at rest and in efforts.

Results and discussions - The obtained results show the efficiency of the complex program that includes kinetotherapy and therapeutic swimming, as well as its role in the prophylaxis of installing vicious attitudes in this category of children. The respiratory and cardiac functions were improved, as well as the somatic indicators. The following procedures were used to swim: crack, bras, back.

Conclusions The kinetotherapeutic treatment together with therapeutic swimming methods allowed the improvement of the somatic and functional parameters. The therapeutic swimming has proved its efficiency in prophylaxis, maintaining or correcting scoliotic attitudes in pre-pubertal children.
\end{abstract}

Keywords: scoliosis, prophylaxis, recovery, therapeutic swimming, kinetotherapy 
L19 - Diagnostic and therapeutic approaches in rehabilitation correlated to a case of tetraparesis (with predominance of paraparesis) after severe CCT - bifronto - basal and bitemporal contusion.

Alexandru G. STAVRICĂ * ${ }^{2}$, Luminiţa Nirlu², Laura Georgiana Popescu², Ana Carmen Albeşteanu ${ }^{2}$, Gelu ONOSE ${ }^{1,2}$

Corresponding author: Alexandru G. Stavrică, e-mail: $\underline{\text { alexandru.stavrica@gmail.com }}$

1. "Carol Davila" University of Medicine and Pharmacy, Bucharest, Romania 2. Neurorehabilitation Clinic, Teaching Emergency Hospital "Bagdasar Arseni" (TEHBA) Bucharest, Romania

\begin{abstract}
Introduction: Craniocerebral trauma (CCT) can be defined as a brain damage caused by an external factor. It may or may not penetrate the skull. Examples of CCT causing sources can be: car accidents, falls (from height or same level), blows with blunt objects, shooting, etc. The diagnosis is generally easy to establish through anamnesis with the patient or witnesses, then by tomography.

Having the patient's consent and The Teaching Emergency Hospital "Bagdasar-Arseni" Ethic committee's approval, N.O. 17464 per 14.06.2019, this article presents the evolution of a 32-year-old male, tetraparetic with predominance of paraparesis, bradylalia and cerebrastenia (with significant improvement) and disgraphy, following a severe CCT - bifronto-basal and bitemporal contusion. Operated temporo-parieto-occipital fracture (right parietal decompression flap) - all by falling off the horse (affirmative). Joint stiffness in the knees (by Pellegrin-Shida heterotopic periosteal calcifications). Total post-traumatic optic atrophy RE and partial optic atrophy LE. Multiple bedsores. Neurogenic bladder (carrier of indwelling urinary catheter). UTI with Proteus Mirabiris (etiologically treated) was admitted in the Neurorehabilitation Clinic of the Teaching Emergency Hospital "Bagdasar Arseni" (TEHBA) for tetraparesis motor deficit, retention sphincter disorders, locomotor and severe auto-care dysfunctions, specialized recovery and nursing treatment with favorable development.

Discussion: The peculiarity of this case is the good evolution of a patient with severe CCT and multiple associated complications. Last but not least, we can highlight how the CCT was produced, namely by falling off the horse. This tells a lot about the importance of the precautions and equipment needed during a sport, in our case wearing a helmet.
\end{abstract}

Key words: cerebral cranial trauma, tetraparesis, paraparesis, recovery, 


\title{
L20 - MANAGEMENT OF SPASTICITY IN NEUROLOGICAL PATIENTS
}

\section{Ana Maria Bumbea, Otilia Rogoveanu, Carmen,Albu Rodica Traistaru, Catalin,Bostina, Bogdan Stefan Bumbea, Roxana Dumitrascu, Borcan Madalina}

Corespondin author: Ana Maria Bumbea anamariabumbea@yahoo.com

\begin{abstract}
Introduction:

Spasticity management is a challenge in neurological rehabilitation, how can we improve the condition of the patient

\section{Materials and method:}

Spasticity is caused by the increased excitability of the peripheral motor neuron through the loss of depressive control. As a result, the commands will be sent to the neuromuscular junction. This will determinate an excessive increase in muscle tone for upper limb flexors and extensions of lower limb. The clinical expression will consist of exaggerating tendon reflexes, altering the rate of movement, and finally the appearance of vicious, inoperative postures. For an objective assessment, specific scales are used: the modified Ashworth scale and the Franchey functional scale.
\end{abstract}

\section{Results:}

It is important to maintain a degree of spasticity at a convenient level, such as Asworth 2 and Franchey over 5. This allows to use a kinetic programs adapted to the patient to improve functionality. However, if spasticity is not controlled, the patient will not be able to perform a proper rehabilitation program. This situation requires additional medication to reduce spasticity. Current therapies are complex from electrotherapy, massage and physiotherapy adapted to the patient, where special attention is given to the serial and repeated stretching programs in a certain sequence. But if spasticity is absent even with flaccidity, again the rehabilitation program will be disturbed by the absence of movement. Currently, the use of correct doses of botulinum toxin associated with shockwave therapy, the spasticity is modulated to allow for a personalized neurological rehabilitation program.

\section{Conclusions:}

Nowadays rehabilitation and pharmacology therapies improve spasticity, but combined and sustained application of botulinum toxin treatment and neurorehabilitation after a personalized program is more effective. 
L21 - Particularities of complex therapeutically-rehabilitative management, stepwise, in a patient with post-CCT psycho-cognitive impairment in a large polytramatic context - CASE REPORT

Laura Georgiana Popescu $^{* 1}$, Luminița Nirlu ${ }^{1}$, Ana Carmen Albeșteanu ${ }^{1}$, Ali Osman Saglam ${ }^{1}$, Gelu Onose ${ }^{1,2}$

Corresponding author: Laura Georgiana Popescu, Email: laurapopescy@yahoo.com

${ }^{1}$ Teaching Emergency Hospital „Bagdasar-Arseni” Bucharest (TEHBA)

${ }^{2}$ University of Medicine and Pharmacy "Carol Davila" in Bucharest, Romania

\begin{abstract}

\section{Hypothesis}

Cranio-cerebral trauma (CCT), associated with other lesions occurring in polytraumatic context, is the most commonly encountered neurological pathology with vital risk in younger patients, often the consequence of road accidents.

\section{Objective}

Having the patient's consent and The Teaching Emergency Hospital "Bagdasar-Arseni" Ethics Committee's approval, N.O. 17464/14.06.2019, this article presents the evolution of a 20 -year-old patient involved in a road accident (driver) with severe $\mathrm{CCT}(\mathrm{GCS}=4)$, multiple pelvic fractures, right clavicle fracture, incomplete fracture of the left transverse apophysis L5 - unoperated, perivesical hematoma, thoraco-abdominal contusion and neurogenic bladder.
\end{abstract}

\title{
Results and methods
}

The data presented include patient history, clinical and imaging examinations, assessments of neuro functional deficits through specific scales, medical and kinetological treatment that led to favorable patient progression from psycho-cognitive status after severe $\mathrm{CCT}(\mathrm{GCS}=4)$ in polytraumatic context associated with anteroretrograde amnesia related to trauma and severe locomotor and self-care dysfunction to psycho-cognitive status in marked improvement, with the patient verticalization, maintaining orthostatism and independent mobilization over medium distances.

\section{Discussions/Conclusions}

The particularity of the case: the favorable progression which emerged after a sustained, sequential, stageadjusted and persistent therapeutic rehabilitation team-run program over a relatively short period of time, in the context of both the contraindication of sitting positioning and the mental state of the patient during hospitalization.

Keywords: neuromuscular rehabilitation, cranio-cerebral trauma, pelvic fracture, polytraumatism, anteroretrograde amnesia related to trauma, 


\title{
L22 - Developing strategies to address comorbidity in stroke rehabilitation.
}

\author{
Adrian MELNIC ${ }^{1,2}$, Oleg PASCAL ${ }^{1,2}$
}

Corresponding author: Adrian MELNIC, E-mail: adrian.melnic@usmf.md,

1. State Univesity of Medicine and Pharmacy "Nicolae Testemitanu", Chişinău, Republic of Moldova 2.Institute of Neurology and Neurosurgery "Diomid Gherman", Chişinău, Republic of Moldova

\begin{abstract}
Introduction. Stroke represents a major cause of mortality and disability worldwide. At the same time rehabilitation provides an opportunity for individuals to ensure quality of life and reintegration to the community. Due to increasing in age and rising rates of the post-stroke survivors, one of the major issues remains comorbidity that can interfere with rehabilitation process. Co-occurrence of multiple chronic disabling conditions represents a burden for patient, family, health care system and needs specific strategies for proper rehabilitation management.
\end{abstract}

Material and method. 387 medical records of patients with stroke admitted at Neurorehabilitation unit of the Institute of Neurology and Neurosurgery from Republic of Moldova during 6 months, were examined retrospectively. A qualitative analysis was performed to study comorbidity profile in stroke patients who underwent rehabilitation. A literature search in PubMed database was done using a combination of terms "comorbidity" or "multimorbidity" and "stroke" and "rehabilitation" in order to select potential strategies to address comorbidity in stroke rehabilitation.

Results and discussions. The average number of comorbidities was 5.52. Total number of different comorbidities included 28 diagnosis codes from ICD 10. According to our data a leading comorbidity in stroke patients was related to cardiac and vascular pathologies including hypertension in $82 \%$, carotid arteries disease in $52 \%$, atrial fibrillation in $24 \%$. Another important group of comorbidities was musculoskeletal pathologies including shoulder pain in $34 \%$, osteoarthritis in $22 \%$, osteoporosis in $12 \%$. The most common conditions from the metabolic diseases subgroup were represented by diabetes in $34 \%$, metabolic syndrome in $18 \%$ and obesity in $16 \%$. Among frequent conditions diagnosed in stroke patients were cognitive disorders (54\%) and depression (36\%). A significant correlation between the number of comorbidities and rehabilitation outcomes measured by Barthel's Index was revealed $(r=-0.81)$. 3D approach (Depression screening, personal Dimensions of health and Drug adherence), integrated and coordinated care plan with specific intervention focusing on comorbidity subgroup are the most promising strategies for rehabilitation of persons with multiple disabling conditions.

Conclusions. Multiple comorbidity is common in stroke rehabilitation and has significant negative impact on functional outcomes. Rehabilitation programs for post-stroke patients should be elaborated according to revealed comorbidity profile. Further research is needed for optimization of management strategy and guidelines for rehabilitation of post-stroke persons with comorbidities.

Key words: stroke, rehabilitation, multiple conditions comorbidity.

\section{References}

1. Chris Salisbury, Mei-See Man, Peter Bower, Bruce Guthrie, Katherine Chaplin, Daisy M Gaunt, Sara Brookes, Bridie Fitzpatrick, Caroline Gardner, Sandra Hollinghurst, Victoria Lee, John McLeod, Cindy Mann, Keith R Moffat, Stewart W Mercer . Management of multimorbidity using a patient-centred care model: a pragmatic cluster-randomised trial of the 3D approach. Lancet 2018; 392: 41-50.2.

2. Michelle L.A. Nelson et al. Stroke rehabilitation and patients with multimorbidity: a scoping review protocol. J Comorb. 2015; 5: 1-10. 


\title{
L23 - Monogenic diseases with musculo articular laxity. Diagnostic criteria and principles of recovery therapy
}

Dorin-Gheorghe TRIFF, Simona POP

Corresponding author: Dorin-Gheorghe TRIFF

\begin{abstract}
Introduction. Monogenic diseases with musculo articular laxity represen a group of heritable connective tissue disorders which in clinical manifestations associate primarily articular hypermobility, besides other signs of conjunctive tissue impairment (skin extensibility, tissue fragility). Diagnosis is often delayed and is based on clinical signs and especially based on genetic tests.

Objectives: Late diagnosis of these diseases can lead to functional impotence (through joint and bone remodeling) while late or inappropriate treatment aggravates the prognosis and quality of life in these patients. Material and method: Literature survey

Results. Particularization of these diseases, which is important in the therapeutic approach, comes primarily from the aspects of etiopathogenesis and genetic diagnosis, hereditary transmission and data known by molecular genetics (allelic variants, gene structure, mapping, phenotype-gene relationships).

The characteristics of these monogenic diseases in terms of evolution, clinical picture, diagnosis and treatment are highlighted for the variants Ehlers-Danlos syndrome, Camurati-Engelmann disease, Carey-Fineman-Ziter syndrome, mandibuloacral dysplasia with lipodystrophy, myotonia with skeletal abnormalities and mental retardation, transient receptor potential cation channel.

Besides these, there are particular aspects of collagen diseases with hereditary transmission with predominance of bone manifestations in the clinical presentation, which also associate articular hyperlaxity (for example Osteogenesis imperfecta) .

The study of distinctive aspects of both clinical assessment (eg mobility scores, Beighton score) but also of Health Related Quality of Life and holistic care of these patients is of great importance in medical practice.

\section{Conclusion}

Although these are relatively rare diseases, early diagnosis and establishment of complex treatment in which medical recovery has an essential role, as well as a holistic approach to patient care significantly improves prognosis and the patients' quality of life.
\end{abstract}

Key words: articular laxity, monogenic diseases, recovery, quality of life 


\title{
L24 - The use of elastic bands in the recovery of ankle sprains
}

\author{
Catalin Ionite $^{1}$, Dragos Arotaritei ${ }^{2}$, Mihai Ilea ${ }^{3}$, Mariana Rotariu ${ }^{4}$
}

Corresponding author: Dragos Arotaritei, E-mail: dragos aro@yahoo.com

\begin{abstract}
Introduction: The lack of movement in the 21st century led to a decrease in the muscular strength of the whole body and implicitly to a decrease in the resistance of the ligament apparatus. Due to these phenomena, the incidence of ankle sprains increased considerably, affecting at least 2,000 people daily.

Material method: The study lot consisted of 15 male, 20-40 year old. They performed two initial and final evaluations, consisting of: articular balance, somatometry and Visual Analog Scale (VAS). Between the two evaluations, each patient underwent a 3-week (15-day) kinetic program. The kinetic program was made exclusively from exercises performed with elastic bands from different derived positions.

At the end of the initial evaluation, the data obtained were quantified, compared and processed using the statistical programs SPSS and Statistica 7.

Rezultate: At the end of the study, the two evaluations (initial and final) were analyzed, observing that following the physical therapy program by the patients, the parameters recorded at the first assessment changed positively from the final evaluation. The articular test increased, indicating an increase in patient mobility, while the somatometry and Visual Analog Scale parameters decreased. This has led to a reduction in edema and a decrease in pain experienced by patients.

Conclusions: The proposed treatment program has had positive results, improving the symptom generated by the ankle sprain. The evaluated parameters underwent positive changes following the kinetotherapeutic program.

Statistical programs helped us interpret the results and get plantar pressure maps for the certification and quality of the treatment program.
\end{abstract}

Key words: elastic bands, ankle sprain, statistical programs, recovery 
L25 - The effects of cube therapy in the recovery of the arthrosis hand in geriatrics

Mariana Rotariu ${ }^{1}$, Marius Turnea $^{2}$, Calin Corciova ${ }^{3}$, Catalin Ionite ${ }^{4}$

Corresponding author: Marius Turnea, E-mail: tmarius ro@yahoo.com

\begin{abstract}
Introduction: The hand is one of the heaviest segments to recover because of the anatomic complexity and the fine movements it has to accomplish. The arthrosis of this segment occurs around 40-50 years of age affecting movement, aggravating daily activity and causing permanent joint pain.

Material method: This paper follows a group of 15 patients diagnosed by the rheumatologist with arthrosis of the hand. Patients treated in the study are over 45 years of age. They received two evaluations (initial and final). The evaluation consisted of completing a Activity Daily Living (ADL) questionnaire such as: button completion, zipping, tableware use, etc.

Between the two assessments each patient received 10 cube therapy sessions within 2 weeks. Each cube therapy session lasted between 30 and 40 minutes. This dosage was based on: the patient's state (physical and mental), the quality of sleep etc.

At the end of the final evaluation, the data obtained were indexed, compared and processed using statistical programs.

Results: The comparison of the two evaluations shows how cube therapy led to an increase in the initial score obtained by each patient in the ADL questionnaire. This device has led to an increase in patient independence in day-to-day activities by: increasing mobility, muscle strength and a decrease in pain experienced by patients in daily activities.

Conclusion: The use of cube therapy has led to positive results in the relief of symptoms caused by arthrosis and the independent patient's ability to perform daily activities. Furthermore, the use of the cube in cases of hand and arthrosis leads to a decrease in the pain experienced by the patient at this level and, implicitly, to his psychological comfort.

The statistical programs helped to interpret the results obtained and provide clear and concise graphics for the physical therapist.
\end{abstract}

Key words: cube therapy, osteoarthritis, statistical analysis, ADL questionnaire. 


\title{
L26 - Fitness and Wellness. Conceptual delimitations
}

\author{
Cristian Ştefan LIUŞNEA
}

Corresponding author: Cristian Ştefan LIUŞNEA, E-mail: stef lius@yahoo.com

\begin{abstract}
Introduction. At the beginning of the 20th century, we can already talk about the emergence of bodybuilding competitions (close to today's), both as a result of E. Sandow's "propaganda", but also because of the interest shown by American businessmen. In parallel to these efforts, the Pan American Health Bureau (PASB) was founded in Washington DC in 1902, and in 1907 in Paris, the International Public Hygiene Office (OIHP). In 1913, the Rockefeller Foundation, the first non-governmental organization in the field, aims to contribute to the welfare of all mankind.

Material and method. The term "fitness" is also used in the sense of "optimal physical condition", ie the ability to efficiently perform any physical activity (training) without completely exhausting the energy resources needed for an emergency, other physical activities. Operating with notions from the mentioned disciplines, which also relate to medicine, with general health, fitness has been defined by some health professionals as their physical condition, well-being or optimal state of health, others speak of physical fitness (Colado, 1996, Colado, Moreno, 2001), determined by the values for muscle strength, physical work capacity, optimal adipose tissue, exercise capacity on a regular basis, exercises aimed at improving the speed and flexibility of the body (Hopkins, Walker, 1988; Douglas, Alan, 1994). As for the concept of Wellness, specialists talk about its nine dimensions: Physical Wellness, Emotional Wellness, Wellness, Wellness, Wellness, Wellness, Wellness and Wellness.
\end{abstract}

Results and discussions. This article related to fitness (physical fitness), lifelong wellness, health and lifestyle management, with the important conceptual delimitations.

Conclusions. It is important to make the distinction between fitness and Wellness or health-related physical fitness and athletic performance physical fitness.

Key words: Fitness, Wellness, Health, Physical activity, physical condition. 
L27 - NSAID THERAPY OF MUSCULOSKELETAL PAINS AND ITS PARTICULARITIES IN THE PATIENTS SUFFERING FROM CARDIOVASCULAR DISORDERS

\author{
Dr. Adriana LUPU \\ Adriana LUPU
}

- Physician, Doctor of Medicine - Senior Lecturer within the School of Medicine and Pharmacy Galați - Family Physician at Launer Clinic Launer - Galaţi

\begin{abstract}

\section{INTRODUCTION}

In the family physician's practice, as first contact with suffering and multiple manifestations of pain, in many cases, after having exhausted various empirical or self-medication methods in order to relieve their pains, desperate and hopeful patients call for the physician's assistance and qualified support.
\end{abstract}

\title{
REASONS FOR CHOOSING THE TOPIC
}

Specialty studies found the large-scale use of NSAID against disorders targeting patients in general, but also elderly patients running especially a cardiovascular risk; that is why we wish that the data to be provided within this presentation represent a knowledge tool supporting both professionals and less informed patients who wish to manage pain on their own, without specialized support. Based on our own experience, we set out to present the efficiency of the treatment with NAPROXEN cp. $250 \mathrm{mg}$. administered in small doses and on short periods of time to patients suffering from musculoskeletal disorders and elderly with predominant cardiac pathology.

\section{MATERIAL AND METHOD}

For the achievement of the proposed objectives, the topic has been structured on sub-chapters as follows:

- Pain - multiple sensation: affective-emotional, cognitive and behavioural; epidemiology; factors that might influence the intensity of pain and how it is perceived; classification of pain depending on: algogenic component, evolution, location, aetiology; features of acute and chronic pains and the musculoskeletal pain etc.

- NSAID - first line treatment of musculoskeletal pains starts by emphasizing chronological milestones in the discovery and usage of antalgics and continues with the presentation of nonsteroidal anti-inflammatory drugs: features, classification, disorders treatable with NSAID, their action manner and side effects etc.

- Treatment with NAPROXEN cp. $250 \mathrm{mg}$. administered in small doses and on short periods of time to 100 patients suffering from musculoskeletal disorders, elderly and those having predominant cardiac pathology, compared with 42 patients treated with other NSAID.

\section{RESULTS}

The assessed lot's BP was monitored at the beginning, on the $5^{\text {th }}$ and $11^{\text {th }}$ day after completing the treatment and, comparatively, with the patients treated with other NSAID. The patients treated with NAPROXEN $\mathrm{cp}$. $250 \mathrm{mg}$., in a short cure and small doses, did not develop pressure increase or other cardiovascular symptoms and the pain symptomatology was significantly reduced.

\section{CONCLUSIONS}

In comparison with the number of patients treated with other NSAID, who developed major blood pressure increases, which caused the treatment to be stopped, the treatment with NAPROXEN cp. $250 \mathrm{mg}$. did not cause significant cardiovascular issues, the WOMAC and VAS scale results showing improved scores.

KEY WORKDS: Musculoskeletal pains, NSAID, cardiovascular disorders, NAPROXEN, 


\title{
L28 - CLINICAL-EVOLUTIVE PARTICULARITIES AND A MULTIMODAL THERAPEUTIC-REHABILITATIVE, AS WELL AS THROUGH CONNECTED CARES, APPROACH, IN A CASE OF HEMIPLEGIA AFTER ISCHEMIC CARDIO-EMBOLIC STROKE WITHIN A POLYPATHOLOGICAL CONTEXT
}

\section{$\underline{\text { Mihaela MANDU }}{ }^{1}$, Cristinel Dumitru BADIU ${ }^{1,2}$, Raluca PETCU $^{1}$, Cosmin OPREA $^{3}$, Gelu} ONOSE ${ }^{1,2}$

Corresponding author: Mihaela Mandu, E-mail: mihaelamandu37@yahoo.com

1. "Bagdasar Arseni" Clinical Emergency Hospital, Bucharest

2. "Carol Davila" University of Medicine and Pharmacy, Bucharest 3. "Filantropia" Municipal Hospital, Craiova

\begin{abstract}
Introduction: Cardiac embolism is one of the most common causes of embolic CVA. It is also responsible for some of the CVAs which are considered cryptogenic, that is, without a deceiving cause. Because cardioembolic causes leading to stroke are pretty well known (atrial fibrillation, bacterial endocarditis, thrombi, or intracardiac tumors), the incidence of cardioembolic stroke has decreased in recent years due to prophylaxis, imaging and therapeutic progress. The recovery of patients with cardioembolic stroke is a complex process which requires taking into account all associated pathologies (e.g. diabetes mellitus) that can play a decisive role in the evolution of the patient. A multidisciplinary team is required for such a purpose.

Material and methods: Having the patient's consent and the approval of the Ethics Committee of "BagdasarArseni" Clinical Emergency Hospital, N.O. 17464/14.06.2019, the paper presents the case of a 63-year-old patient with ataxic spastic hemiparesis and left facial paresis with cerebration and bradycardia, post-ischemic stroke in the carotid region (January 2019). The patient was admitted to our clinic for motor deficit hemiparesis, locomotor dysfunction and severe selfcare, stage recovery treatment. Other important elements in the patient's pathological history is insulin-dependent type 2 diabetes, severe carotid and vertebrobasilar atheromatosis, ischemic coronary disease, stage III essential high blood pressure, operated type III aortic-iliac occlusive disease, stage IV right lower limb chronic ischemia, Fontaine with ulceration at the level of the calf contaminated with Proteus, which required the surgical excision of the necrotic area, fasciectomy, and defect covering by freely detached skin. Given the complexity of the case, a multidisciplinary team was required, consisting of a medical rehabilitation doctor, a cardiologist, a diabetologist, an imaging physician, a plastic surgeon and an infectious disease physician. The patient was clinically and functionally evaluated, according to the standardized protocols implemented in our clinic, through the assessment scales (MMSE, GOS-E and Rankin, MoCA, FIM, QoL-Quality of Life, FIM) and also paraclinically, in order to evaluate his biological reserve and its bearing availability of the recovery program.

Results: The patient presented a slowly favorable evolution (slowed down not only by his multiple above mentioned comorbidities, but also by his affective bioactive lability with depressive, negative behavior) from an algo-dysfunctional point of view, with the improvement of the walking program and the increase of muscle strength and individual autonomy.

Conclusion: In recent years, the incidence of cardioembolic stroke has decreased due to prophylaxis, imaging and therapeutic progress. The recovery of patients with cardioembolic stroke is a complex process, which requires taking into account all associated pathologies that can play a decisive role in the evolution of the patient. A multidisciplinary team is required for such purposes.
\end{abstract}


L29 - Multimodal- rehabilitative therapeutical approaches in a complex of pathology including possibly evolving discariotic type - CASE REPORT

$\underline{\text { Ana Carmen Albesteanu }}{ }^{1}$,_Laura Georgiana Popescu ${ }^{1}$, Luminița Nirlu ${ }^{1}$, Ali Osman Saglam ${ }^{1}$, Gelu Onose ${ }^{1,2}$

Corresponding author: Ana Carmen Albesteanu, Email: ana.albesteanu@gmail.com

${ }^{1}$ Teaching Emergency Hospital „Bagdasar-Arseni” Bucharest (TEHBA)

${ }^{2}$ University of Medicine and Pharmacy "Carol Davila" in Bucharest, Romania

\begin{abstract}

\section{Introduction}

Having the patient's consent and The Teaching Emegency Hospital "Bagdasar-Arseni" Ethics Committeee N.O 20270 from the 26of June 2019, the current case report presents the case of a female patients with both hemiplegia following a thalamic vascular accident and a long history of neglected auricular melanoma.

The management of a patient diagnosed with melanoma is a complex one, involving wide local excisions with safety margins, with sentinel lymph node biopsy. Auricular melanomas have recently evolved from radical procedures involving the amputation of the involved organ, to much less radical procedures, which help save more of the patient's tissue and functionality. (1) Another important factor that threatens the rehabilitation process in the case of hemiplegic patients is the presence of clinical depression, both as a pre-existing comorbidity and as a common psychiatric complication of stroke. (2) Depression jeopardizes the patient's quality of life and increases mortality. (2)

There is also relevant date supporting the hypotheses that depression history is associated with melanoma risk, although no effect on survival was observed. (3)
\end{abstract}

Materials and Methods

A 70 years old pacient, which suffered right thalamic vascular accident in december 2018 was admitted in our Neuromuscular clinic division with the following comorbidities: basal-cell carcinoma (BCC), diagnosed 20 years ago, with slow evolution. When admittedin our division, the pacient presented with a moderately large ulcerated tumor in the temporal region and the left auricular pavilion - with surgical indication. She was also diagnosed with arterial hypertension stage III, chronic cardiac insufficiency class III NYHA, chronic cervicalgia and lumbosacralgia, class II obesity, clinical depression.

She was admitted into our clinic for hemiplegic motor deficit, sensibility disorders, severe locomotor and self-grooming dysfunction.

\title{
Results
}

The patient improved on most of the assessment scales/scores implemented in our Clinic's Division Motor FIM (Functiona Independence Measure) from 35/91 to 38/91, FAC (Functional Ambulation Categories) from 0/5 to $1 / 5$, GOS-E (The Extended Glasgow Outcome Scale) from 4/8 to 5/8. The most important improvemet in our patent's evolution was her ability to start walking again. During her admission into our Clinic, she was also briefly admitted into the hospital's Plastic Survery Divison, where she received the necessary surgical trateament for the melanoma.

\section{Conclusions}

Following a complex neuro-recovery program developed by a multidisciplinary team made of doctors, kinesio-therapists, middle and allied health personnel, the patient had an extremely good evolution (during a short period of time) - attested on the scales and also - on a psycho-cognitive and behavioral level. 


\title{
L30 - Attachment - prognostic factor in medical recovery
}

\author{
Liliana Padure, Cristian Adam, Laura Fierbinteanu
}

The National Teaching Centre for Neuro-psycho-motor Rehabilitation in Children "Dr. N. Robanescu", Bucharest, Romania

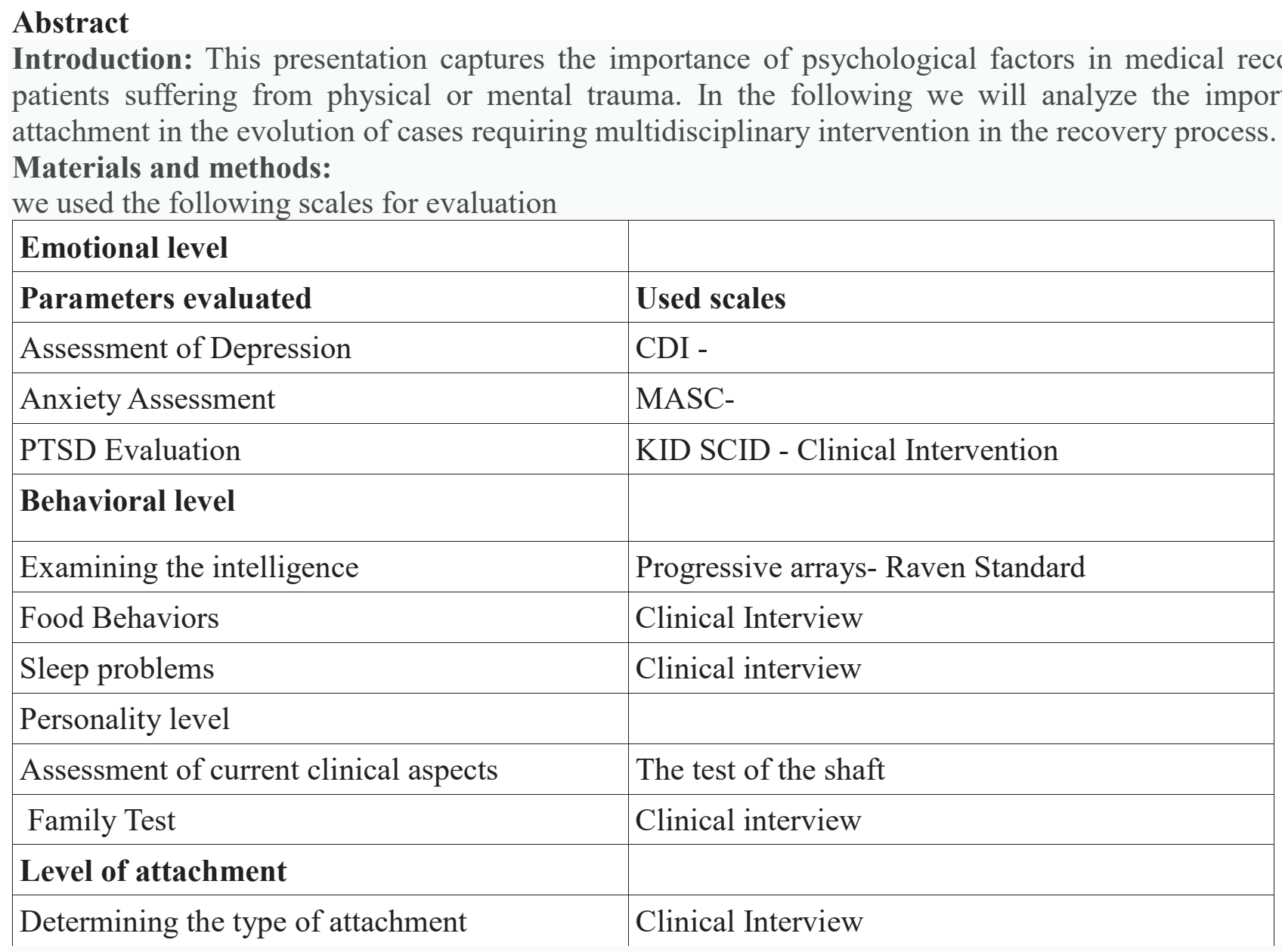

Results: Following the evaluations we found 2 attachment types, securing attachments and insecure/avoidant that develop or not have psychiatric-emotional symptoms of anxiety / depression/PTSD, although the cognitive level is normal for most of the subjects, essential for recovery is the presence of a secure and intelligent emotional attachment.

Conclusions: A safe attachment is a positive prognostic factor in recovery, unlike insecure attachment, which is a negative prognostic factor. 


\section{L31 - Motility or Morbidity in Neurosurgery Motto: „I move, therefore I am” (Haruki Murakami, Japanese Writer)}

Alexandru Vlad Ciurea ${ }^{1,2}$ MD., PhD., MSc., Dr. h.c. Mult.

Prof. Alexandru Vlad Ciurea - e-mail: prof.avciurea@gmail.com

Abstract

\section{Background :}

„The lack of motion is a basic process in the birth of diseases”. (Hipocrate 460BC-370 BC)

Biological motility is the capacity of an organism to move spontaneously and voluntary at the expense of energy and represents one of the crucial traits (if not the most important trait) of all living matter. Motility is a key process present in unicellular organisms as well as multicellular organisms and is the basis of embryonic development, would healing, immune response, tumor formation, metastasis, cell migration, digestion, circulation, respiration and reasoning and various other critical processes including biological evolution itself. The constant motility of developing organisms (from trilobites to human beings) has undoubtedly shaped evolution by constantly improving the functions of the skeletal system and other internal organs such as the digestive tract, liver, kidneys etc.

The evolution from prehistoric human beings to modern men went through several steps during which human motility represented once more a crucial element. Once industrial food production appeared - with the overproduction we are familiarized with, human motility became a protection factor against obesity which is one of the most problematic medical conditions of our time.

The first important scientific evidente base was: Brownian motion (Robert Brown in 1828) when he noted that the particles (pollen grains) moved randomly through the water. Diffusion or brownian motion is the random motion of particles suspended in a fluid (a liquid or a gas) resulting from their collision with the quick atoms or molecules in the gas or liquid. A brown motion theory was explained in modern sense by Einstein (1905).

\section{Materials and methods :}

Classical physics describes motion to be the change in position of an object with respect to time and its refference point. Motion in the universe is described using two apparently contradictory sets of laws. The motion of familliar objects - including cells - are described by classic mechanics while the movement of atoms and subatomic particles are described by quantum mechanics.

As creatures evolved, various types of motility were developed - these include chemotaxis (motility along a chemical gradient), thermotaxis (motility along a temperature gradient), phototaxis (motility along a light gradient), magnetotaxis (motility along a magnetic field), galvanotaxis (motility along an electrical field), gravitaxis (motility along the direction of gravitational force), durotaxis (motility along a rigidity gradient), haptotaxis (motility along a gradient of cell adhesion sites) and many others. Nowadays researchers only begin to understand the crucial part motility played in the evolution of species.

All surgical interventions (cheiron+ergon = gesture done by hand) represent - in broad lines - small controlled traumas with the sole purpose of removing tumors (surgical oncology), removing foreign bodies and restoring organ integrity (trauma surgery), restoring vascular flow to the body (cardiac surgery and vascular surgery), decompressing the brain (neurosurgery) and so on. In all areas of surgery cell and tissue motility is singlehandedly the key to healing and succes.

The evolution from prehistoric human beings to modern men went through several steps during which human motility represented once more a crucial element. Once industrial food production appeared - with the overproduction we are familiarized with, human motility became a protection factor against obesity which is one of the most problematic medical conditions of our time. 
According to WHO data, in 2014 there were more than 1.4 billion adults aged 20 or more who were overweight. More than 500 million people are obese while more than 40 million children suffer of this ailment. Physical activity (motility) is the best solution! Swimming, Tennis, Cycling and limiting of hypercaloric food intake are the symplest and most effective ways to get rid of obesity and improve the individual quality of life and treatment for all medical patients.

As soon as „fast track" surgery began being implemented in hospitals, neurosurgeons took the concept and adapted it to neurosurgery. Besides the critical concern for the patient's motility expressed through diffuse tensor immaging (DTI) fiber tracking, doctors began to understand that the key to a fast neurosurgical recovery is a fast treatment. The patient should firstly be able to move spontaneously and independantly and secondly he should be able to do that as soon as possible after surgery. Pulmonary thrombembolism is therefore avoided, intestinal transit is ensured, csf transit is ensured, complete body motions are ensured and the nervous system is stress-free. Provided the fact that any lesions of the brain have a tremendous impact of the motility of the patient the authors consider that the motility of the patient has a tremendous impact on the healing of the patient.

The authors extensively motility \& neurorehabilitation work in traumatic or nontraumatic all neurosurgical disorders .

The authors insist on prevention of thromboembolism phenomena of increased muscle tone, family reintegration, social and professional, for patients with neurosurgical disorders.

Motility and quality of life through rehabilitation , framed by neuro - rehabilitation is major phenomenon there is continuous feedback between central command and response musculoskeletal peripheral joint.

In the current vision, can no longer conceive a department of neurosurgery, without the adjacent neurorehabilitation .

Conclusions - we believe that motility is the key to limiting and improving worldwide morbidity while also limiting the effects of other diseases and increasing the healing rates of other pathologies while also preventing thrombosis. Neurosurgical and neurovascular pathologies are prime targets for early motility of patients. Under these circumstances a modern medicine without early postoperative mobilization of the patient is no longer concievable, a fact which is in strict accordance with the old saying in the bible , Take up your bed and walk"(John 5:8).

Key Words: Neurosurgery, Mobility, Morbidity, Evolution, Outcome 
L32 - EXERCISES PROGRAM AND REHABILITATION IN PARKINSON'S DISEASE

Valerica CREANGA-ZARNESCU ${ }^{1,}$ Ana-Maria FATU ${ }^{2}$, Anamaria CIUBARA ${ }^{3}$, Violeta SAPIRA ${ }^{4}$,Aurelia ROMILA ${ }^{5}$, Mihaela LUNGU ${ }^{6}$,

Corresponding author: Valerica CREANGA-ZARNESCU, E-mail: zarnescu_vally@yahoo.com

- $\quad 1,2$-PhD student, Faculty of Medicine and Farmacy "Dunarea de Jos" University of Galati , 47 Domnească Street, RO-800008, Galati, Romania

- 3- Prof., Head of Neurological Department of Psychiaty, Faculty of Medicine and Pharmacy, "Dunarea de Jos",Galati, Romania.

- 4- Assit. Prof., Neurological Department, Clinical Emergency Hospital Galati, Faculty of Medicine and Farmacy "Dunarea de Jos" University of Galati , Romania - 5-Assoc.Prof.,Clinical Emergency Hospital Galati, Faculty of Medicine and Farmacy "Dunarea de Jos" University of Galati, Romania - 6- Assoc. Prof., Head of Neurological Department, Clinical Emergency Hospital Galati, Faculty of Medicine and Farmacy "Dunarea de Jos" University of Galati, Galati, Romania

\begin{abstract}
IntroductionParkinson's disease is the second neurodegenerative, multisystemic disease after Alzheimer's disease which affects the motor, cognitive and vegetative execution activities. Currently in Romania there is an incidence of 40-50 cases/100.000 occupants/year and a number of 70.000 patients, numbers which are increasing.
\end{abstract}

Material and methodParkinson's disease(PD) is a progressive disorder, the natural course of symptoms varying from case to case in the final stages being even invalidating for the patient. Patients with Parkinson's disease can be divided into two main categories: those in whom the clinical picture is marked by stiffness and akinesia with or without the minimum resting tremors and those in whom resting tremors predominate. Medical rehabilitation programs have a vital and unique role in relieving motor deficits. Recent studies suggest that with the onset of motor affecting, in addition to pharmacological therapy, the introduction of adjuvant therapy programs such as active passivekinesiotherapy, physiotherapy, massage and occupational therapy are designed to improve mobility, speed, coordination, balance and walking, also useful for relieving bradykinesia, stiffness or tremor. Exercising may have protective effects by making dopamine more effective in the brain. Regarding non-motor symptomatology, phono-articular musculoskeletal exercises and orthophony aim to treat speaking and swallowing disorders and cognitive stimulation procedures improve cognitive deficits. A challenge is represented by patients presenting in the rehabilitation service for other conditions such as stroke or post-orthopedic interventions and subsequently being diagnosed with Parkinson's disease. The results clearly suggest that the presence of vascular disease may aggravate PD severity .The reason for which the ideal rehabilitation team must contain: neurologist, medical rehabilitation physician, psychiatrist, psychologist, kinesiotherapist, speech therapist and nutritionist.

Conclusion In recent years, multidisciplinary rehabilitation treatment has gained a key role in improving the quality of the life of the patient with Parkinson's disease, providing both the necessary medication and the adaptive changes that are so useful in relation to the progressive chronic evolution of the disease. 
L33 - The cardiac rehabilitation in patients with acute myocardial infarction

Dr. Irina VERINCEANU ${ }^{2}$, As. Univ. dr. Alice MUNTEANU ${ }^{1}$, dr. Andreea STOICA ${ }^{2}$, Stefan ISPAS ${ }^{2}$

Coresponding author: Irina VERINCEANU, Email: aniri.irina@yahoo.com

${ }^{1}$ Carol Davila Central Military Emergency University Hospital, Bucharest, Romania

${ }^{2}$ County Emergency „dr. Pompei Samarian” Hospital, Calarasi, Romania

\begin{abstract}

\section{Introduction}

Myocardial infarction represents a major health problem being the main cause of mortality and morbidity in developed countries. An acute myocardial infarction is a life threatening condition and often causes impairment of quality of life for the patients and for the family.

According to European Society of Cardiology's guidelines, after myocardial infarction, a patient receive an optimal medical treatment. For secondary prevention is very important to educate the patient and promote adherence to drug therapy and life changes. Also the social reintegration, regain the physical capacity and return at work as soon as possible are very important for limitation of illness anxiety and reduce the risk of death or recurrence of the cardiac event.

Cardiac rehabilitation has been defined by the World Health Organization as: "the sum of activities required to influence favorably the underlying cause of the disease, as well as to ensure that patients' best possible physical, mental and social conditions so that they may, by their own efforts, preserve, or resume when lost, as normal a place as possible in the life of the community."
\end{abstract}

\title{
Conclusions
}

Cardiac rehabilitation has three steps. The first step occurs in the first 14 days and it is represented by early mobilization monitored by a specialized person. After that, for 1-2 weeks the patient starts recovering the physical capacity by gradual exercises. Also he learns how to accept the disease and the importance of life style changes and of medical treatment. The last phase lasts for 6-12 months for fully recovery.

Cardiac rehabilitation is essential for fully recovery of post myocardial infarction patient and for prevention of recurrence of the cardiac event. 
L34 - Statistical analysis of physiotherapeutic means used in the recovery of muscle injuries in athletes

\begin{abstract}
Introduction: The competitive sporting activity carried out under the conditions of total employment, in order to achieve the best performances, is often at the limit of the individual possibilities. Exceeding these limits often leads to injuries of muscle tissue.

Material method: This study was conducted on a group of 15 athletes within the age of 18-35 years. All study participants benefited from initial and final assessment consisting of: muscle testing, articular testing, somatometry and Visual Analog Scale (VAS).

Between the two evaluations, they benefited from a treatment protocol consisting of: passive stretching, neuroproprioceptive facilitation techniques (slow reversal, slow reversal with opposition) and therapeutic exercise.

The data obtained from these evaluations were quantified, analyzed and processed using the statistical programs SPSS and Statistics 7.

Results: After comparing the results obtained, an increase in articular mobility tested with concomitant increase in muscle strength in each patient was observed. The somatometry obtained in the evaluations also changed, lowering the values below those initially obtained. This shows a decrease in edema recorded by each patient, and this result automatically results in lowering the VAS.

The statistical processing confirmed our results. The pressure map constructed with the help of the collected results helps us with a better choice of treatment as well as a real-time comparison with the standard literature results.

Conclusion: Following the results of the proposed physiotherapeutic treatment for muscle injuries, it has a positive effect. physiotherapeutic treatment had led to an increase in articular mobility, an increase in muscle strength, a decrease in edema, and a decrease in pain experienced by patients.

Statistical programs have provided a qualitative contribution to kinetotherapeutic treatment by simulating plant-pressure maps, showing the therapist's permanent points of treatment.
\end{abstract}

Keywords: physiotherapy, muscle injuries, statistical processing, athletes 
L35 - THE ROLE OF IL1ß IN CARTILAGINOUS DISTRUCTION IN RHEUMATOID ARTHRITIS

1- The University of Medicine and Pharmacy „Gr. T. Popa” Iasi

2- Institute of Cardiovascular Diseases "Prof. dr. George I.M. Georgescu” Iasi

\begin{abstract}

\section{Introduction}

Rheumatoid arthritis is a chronic systemic inflammatory disease with unknown etiology and autoimmune pathogenesis, with deforming and destructive joint damage.

The latest theories consider that the disease is the result of the action of environmental factors on a predisposing genetic background, which leads to triggering immune mechanisms that lose their protective character and lead to local and systemic inflammation.

Cytokines have been implicated as important mediators of inflammation and joint destruction in rheumatoid arthritis.

IL1 $\beta$ is mainly produced by macrophages. It affects the function of many cell types, especially chondrocytes, fibroblasts, osteoclasts and synoviocytes. It is the prototype of proinflammatory cytokines in rheumatoid arthritis.

\section{Material and method}

The study was conducted on 80 patients with rheumatoid arthritis at different stages of disease evolution over a 2 year period.

Radiological examinations and IL1 $\beta$ dosing were performed at study entry after 12 and 24 months.

Conclusions

IL1 $\beta$ levels correlate in a direct manner with NAD, NAT, DAS28, HAQ, CRP and VSH, respectively indirectly with Sharp scores for narrowing and erosion.
\end{abstract}

Key words: RHEUMATOID ARTHRITIS, IL1b, DAS28. 
L36 - THE ROLE OF THE INFLAMMASOMS IN THE PATHOGENESIS OF INFLAMMATORY REACTION

\author{
Mihaiela CHICU ${ }^{1}$, Eugen BITERE ${ }^{2}$
}

\begin{abstract}
Introduction

Inflammation is a complex process, that play an important role in innate immunity, but also with many interferences with acquired immunity mechanisms.

Innate immunity recognizes a limited number of antigens, compared to acquired immunity that is capable of recognizing a wide variety of infectious or noninfectious aggressors agents.

Infectious agents release certain substances, called PAMPs that may be common to several species. These can be represented by nucleic acids, bacterial proteins, lipopolysaccharides, oligosaccharides.

Beside the PAMPs, the innate immune system recognizes endogenous molecules released from dead or damaged cells, known as DAMPs - represented by: proteins induced by stress, sodium monourat crystals, proteoglycans, mitochondrial components, nuclear proteins.

PAMPs and DAMPs are recognized by PGR receptors that are particulary situated on the mebrane of macrophages and dendritic cells, the vesicles of phagocytosis or cytosis.

A particular mechanism of innate immunity is the inflammasoms formation.

\section{Discussions}

Inflammasoms are multiprotein complexes that form in the cytosol, following the recognition of PAMPs and are designed to activate the inactive precursors of IL1 $\beta$ and IL18. Inflammasoms activation determine a particular type of programmed cell death: PYROPTOSIS - characterized by the ballooning of the cells, loss of cell membrane integrity and the release of proinflammatory cytokines.

An important role of the inflammasoms has been identified in the gout, diabetic atherogenesis, endothelial disfunction in cardiovascular diseases.
\end{abstract}

Key words: Inflammasome, PAMPs, DAMPs, pyroptosis. 
L37 - A topical systematic literature review and reappraisal on essays towards systematizing clinical assessment instruments used to evaluate neuro-functional deficits after spinal cord injuries, mainly in adults, including through the ICF(-DH) conceptual framework

Prof. Dr. Gelu Onose, MD, PhD, MSc ${ }^{1,2}$, Assist. Prof. Eng. Vlad Ciobanu, PhD $^{3}$, RDI Assistant, Eng., KT, PhD Student Corina Sporea ${ }^{4}$

Corresponding author: Prof. Dr. Gelu Onose, E-mail geluonose@gmail.com

DOI: http://dx.doi.org/10.12680/balneo.2019.276

${ }^{1}$ The University of Medicine and Pharmacy "Carol Davila", Bucharest, Romania

${ }^{2}$ The Teaching Emergency Hospital "Bagdasar-Arseni", Bucharest, Romania

${ }^{3}$ Politehnica University of Bucharest, Computer Science Department

${ }^{4}$ The National Teaching Centre for Neuro-psycho-motor Rehabilitation in Children "Dr. N. Robanescu", Bucharest, Romania

\begin{abstract}
Introduction. Since it has been issued, in 2001, the World Health Organization (WHO)'s new paradigm to approach human functioning: International Classification of Functioning, Disability and Health (ICF-DH), is progressing towards implementation. Accordingly, there is a justified object, including to systematize clinical assessment instruments used to evaluate neuromotor-functional deficits after spinal cord injuries (SCIs) especially as, at present, there are used a quite large number of such measurement tools (some of them availed for evaluation in other disabling sufferance, too).

The above mentioned (WHO)'s modern kind of endeavor matches with another contemporary advanced concept: of "Evidence-based Medicine" - an already renown proceeding for correct and complete/ minute diagnosis and prognosis, and respectively, for consequent, specific therapeutic-rehabilitative, social, occupational - if applicable - decision-making, and consequent appropriate interventions.

Material and method. This work mainly focuses on the respective scales used in adults (the SCI in children - mostly - and in adolescents being comparatively rare, yet obviously, entailing multimodal particularities), based also on a preliminary systematic (and extended) literature review - that emphasized quite scarce dedicated published reports in this respect, thus supporting our choice for the (re)quested niche.

Results. This approach encompasses:

- a systematic (and extended) related literature review

- an overall, concise, pointing of main epidemiological and clinical features of SCIs

- a brief general overview on the WHO's ICF(-DH)

- a synthesis, including with some customized considerations, of the quantification scales used in SCIs and their proposed framing within the ICF(-DH).
\end{abstract}

Conclusions. General remarks and future perspectives in the field.

Key words: systematic literature review, spinal cord injury/es (SCI/s), International Classification of Functioning, Disability and Health (ICF-DH), assessment instruments/ measurement scales

\title{
Selected references:
}

1. International Classification of Functioning Disability and Health (ICF). World Health Organization (WHO) - Geneva, 2001; https://www.cdc.gov/nchs/data/icd/icfoverview_finalforwho10sept.pdf

2. World Health Organization. (2007). International classification of functioning, disability and health: children and youth version: ICF-CY. World Health Organization. https://apps.who.int/iris/handle/10665/43737

3. Preferred Reporting Items for Systematic Reviews and Meta-Analyses (PRISMA) - http://prismastatement.org/documents/PRISMA\%202009\%20flow\%20diagram.pdf

4. Shirley Ryan AbilityLab - https://www.sralab.org

5. Kahn, J., Newman, C., Palma, P., Romney, W., Tappan, R., Tefertiller, R. et al. - Spinal Cord Injury EDGE Task Force Outcome Measures Recommendations (http://www.neuropt.org/practice-resources/neurologysection-outcome-measures-recommendations/spinal-cord-injury; http:/www.neuropt.org/docs/sci-edge/sci-edge-ratings-by-construct-summary.xlsx?sfvrsn=2) - Academy of Neurologic Physical Therapy http://www.neuropt.org 


\title{
L38 - THE ACQUISITION OF SELF-DEFENSE TECHNIQUES AND PROCEDURES AGAINST THE ACT OF AGGRESSION IN THE PACIENT WITH PARAPLEGIA, WHEEL-CHAIR INDEPENDENT
}

Diana-Elena SERBAN $^{1}$, Aurelian ANGHELESCU ${ }^{1,2}$, Elena CONSTANTIN ${ }^{1}$, Gelu ONOSE ${ }^{1,2}$

Corresponding author: Aurelian ANGHELESCU, Email: aurelian anghelescu@yahoo.co.uk

1. Clinical Emergency hospital "Bagdasar Arseni", Bucharest 2. University of Medicine and Pharmacy "Carol Davila", Bucharest

\begin{abstract}
Introduction: Wheel-chair dependend individuals are often the target of aggressors, due to the fact that they can't protect themselves in order to escape from a conflictual situation. Self defense for the wheel-chair users have a special semnification, because of the fact that men with disabilityes are two times more susceptible for being attacked, according to the USA Buireau of Justice.

The aggressors are perceiving the person in wheelchair as an easy victim. This psychological aspect can provide the element of surprise, because the aggressor can be countered through self-defense techniques performed by the victim.

Obiectives: The acquisition of self defense techniques and procedures in the young pacient with wheelchair independed paraplegia, with he purpose of protection in dangerous situations.

Material and methods: Having the patient consent and the approval of the Ethics Committee of "BagdasarArseni" Clinical Emergency Hospital, N.O. 17464/14.06.2019, this paper presents a young patient with the diagnosis of complete paraplegia AIS-A, with T11 neurological level, independent with wheelchair, ex sportsman, witch was instructed with various taekwondo techniques and maneuvres such as: blocking an attack with the hand at the head region (Olgul Jireugi), hand block (Olgul Maki), hand counteratack (Momntong Jireugi), foot attack at the head region (Olgul Dollyo Chagi), hand block (Sonnal Olgul Maki), hand counterattack (Arae Jireugi) etc.

The person who has the role of the attacker has a black belt in taekwondo, therefore the maneuvres were performed in total safety, without endangering the young pacient.

Results: We realized photographs and films that demonstrate the possible scenarios of aggression that the victim can experience.

Conclusions: Prevention, as a self defense method, is essential. The best way is to avoid conflictual situations, but ideal is to be prepared for any situation.

The purpose of this paper is the acquisition of self defense techniques for the pacient with wheel chair independent paraplegia, with the purpose of improving: safty, grade of participation, self-esteem and the quality of life.
\end{abstract}


L39 - "Prevention is cure, education is essential" - responsible implication of young people in educational and prophylactic actions against accidental cervical spinal cord injury and severe disabilities by diving in unverified waters.

Aurelian Anghelescu ${ }^{1,2}$, Elena Constantin ${ }^{1}$, Anca Sanda Mihaescu ${ }^{1}$, Ionut Octavian Frecea ${ }^{1}$, Gelu Onose ${ }^{1,2}$

Coresponding author: Aurelian Anghelescu, E-mail: aurelian_anghelescu@yahoo.co.uk

DOI: http://dx.doi.org/10.12680/balne0.2019.276

1. Teaching Emergency Hospital "Bagdasar-Arseni” (TEHBA), Bucharest, Romania 2. "Carol Davila" University of Medicine and Pharmacy, Bucharest, Romania

\begin{abstract}
Introduction: Encouraged by the favorable outcomes of previous mediatic national prophylactic campaigns, initiated and sustained by the medical team of Teaching Emergency Hospital "Bagdasar-Arseni" and National TV Channels (ProTv, TVR1) focused on the risk of severe disability after cervical spinal cord injury (CSCI) by diving in unknown waters, we decided to continue increasing awareness education actions. The previous prophylactic campaigns were followed by a statistically significant reduction in the number of young patients admitted to hospital with quadriplegia after diving in unverified waters (26.8\% in 2016 and 39\% in 2017). Starting from the ISCoS paradigm "Prevention is cure", we have resumed the prophylactic educational actions addressed to healthcare professionals (students, residents, young doctors) in campaigns to prevent CSCI and accidental tetraplegia during summer sports.

The objective of the study was to test medical, diving biomechanical level of knowledge and circumstances regarding risks associated with diving in unknown waters, among young kinetotherapy FMAM students (under the age of 35). The study has the Teaching Emergency Hospital "Bagdasar-Arseni" Ethics Committee's approval NO 17464/14.06.2019.
\end{abstract}

Materials and methods: The research was conducted using the questionnaire technique, containing 16 closed questions addressed to a number of 40 students.

Results: We observed that most of the young students act precociously: $67.5 \%$ swim in special designated places, $77.5 \%$ dive with their feet first, versus $22.5 \%$ plounge the head first.

Students have a low level of knowledge about biomechanics of plunging and the impressive speeds reached during diving. More than two-thirds of them did not answer the question about the speed reached during diving from $1 \mathrm{~m}[7.5 \mathrm{~m} / \mathrm{s}$, equivalent to $27 \mathrm{~km} / \mathrm{h}](67.5 \%$ students $)$, from $10 \mathrm{~m}$ platform $[17.5 \mathrm{~m} / \mathrm{s}, 63 \mathrm{~km} / \mathrm{h}](70 \%$ students) and diving from $30 \mathrm{~m}[25 \mathrm{~m} / \mathrm{s}, 90 \mathrm{~km} / \mathrm{h}](67 \%$ students $)$.

Regarding the alcohol consumption before diving, $80 \%$ of them responded with "no", and only $5 \%$ responded with "occasional consumption".

Eighteen students (45\%) know the main risk of diving in unknown and shallow waters, and 20 students $(50 \%)$ have responded incorrectly.

Conclusions: Young students - future therapists have a low level of knowledge about CSCI risk and the severe disabilities that can occur accidentally by diving.

It is mandatory to continue the education prophylactic initiative sustained activity through mass media, started in 2016-2018. "Prevention is cure, education is essential" 


\title{
L40 - REHABILITATION RESULTS IN A PATIENT WITH INCOMPLETE AIS/FRANKEL D TETRAPLEGIA AFTER CERVICAL SPINAL CORD INJURY ON THE BACKGROUND OF ANKYLOSING SPONDYLITIS
}

$\underline{\text { Alexandra-Madalina SPORICI }}^{1}$, Irina ANGHEL ${ }^{1}$, Lapadat MAGDALENA ${ }^{1}$, Gelu ONOSE ${ }^{1,2}$

Corresponding author: Alexandra-Madalina SPORICI, Email: alemada22@yahoo.com

1. Clinical Emergency hospital "Bagdasar Arseni", Bucharest

2. Universitybof Medicine and Pharmacy "Carol Davila", Bucharest

\begin{abstract}
Introduction: Ankylosing spondylitis is a chronic inflammatory disease that affects the spinal cord. Usually the onset of the disease is between the second and third decade of life with higher prevalence in men than in women and variable evolution, patients being at risk of vertebral fractures to low or moderate trauma due to increased kyphosis and rigidity of the spine.

Materials and methods: This paper presents a case of a 65-year-old man, chronic ethanol-consumer, hypertensive, former smoker, known with ischemic heart disease, asthma, kidney stones, and a previous C4C5 fracture(in 2012) which also occured on the background of ankylosing spondylitis. He was hospitalized in Neuromuscular Rehabilitation Clinic Division by transfer from the Neurosurgery II Clinic Division of TEHBA, for incomplete AIS/ Frankel D tetraplegia with C5 neurological level, neurogenic bladder, and neuromotor rehabilitation program.

Upon admission, the patient was conscious, cooperative, imobilized in Halo-West system, presenting slightly psychomotor agitation, with bilateral motor deficit, predominantly on the left side. During hospitalization, he presented wet cough along with dyspnea, decreased oxygen saturation, for which intermittent oxygen therapy was administered, with recovery of the respiratory function. The post-operative scar was daily dressed and cleaned and sutures were suppresed after 14 days. Post-operatory CT scan revealed vertebral column in axis, bone fixation material well positioned and Hallo-West system removal with complete subsequent mobilization was decided after 4 weeks of bed rest.

The patient has been functionally assessed using the scales: AIS/ Frankel, Ashworth modified, Functional Independence Measure (FIM), Life Quality Assessment (QQL), FAC International Scale, Independence Assessment Scale of Daily Living (ADL/IADL), Walking Index for Spinal Cord Injury (WISCI).

Results: The patient has benefited from a complex rehabilitation program with favourable evolution: sphincter re-education, regain ability of walking on short and medium distances, control of associated diseases, prevention of complications, improvement of functional status, increase of muscle strength on upper and lower limbs.

Conclusions: Associating appropriate care measures with a customized rehabilitation program in a patient with C5 AIS / Frankel D incomplete tetraplegia and ankylosing spondylitis background, improved the quality of life.
\end{abstract}


L41- CLINICAL, PARACLINICAL ASPECTS AND COMPLEX THERAPEUTICAL APPROACHES IN A PATIENT WITH INCOMPLETE PARAPLEGIA, POST THORACIC MENIGIOMA SURGICALLY TREATED, IN NEUROFIBROMATOSIS CONTEXT

Ioana Andone, Carmen Chipăruș, Andreea FRUNZA¹, Aura Spînu ${ }^{1}$, Simona STOICA ${ }^{1}$, Liliana Onose ${ }^{3}$, George PATRASCU ${ }^{1}$, Gelu Onose ${ }^{1,2}$

ioanaandone11@yahoo.com

${ }^{1}$ The Teaching Emergency Hospital "Bagdasar-Arseni” (TEHBA), Bucharest, Romania, ${ }^{2}$ The University of Medicine and Pharmacy "Carol Davila" (UMPCD), Bucharest, Romania, ${ }^{3}$ The Medical Service of Metrorex SA, Bucharest, Romania.

\section{Abstract}

Introduction: Neurofibromatosis - type 1 (NF1) and type 2 (NF2) - are genetic disorders of the nervous system that can affect the growth and development of nerve cell tissue and so can determine severe or rather permanent sequels. NF2 implies usually multiple tumors on the cranial and spinal nerves and it is less common than NF1. The most frequent symptom of NF2 is hearing progressive loss, as a consequence of auditory nerves affection and appears at early ages or at twenties. The evolution of a patient with NF2 depends on the number and location of tumors and some of them might develop a life-threatening or disabling condition. With a prompt diagnosis and an appropriate therapy it can be improved the patient prognosis and QOL.

Materials and Methods: This paper presents the case of a 43-year-old patient, with personal antecedents of hearing dysfunction, diagnosed in 2013 with neurofibromatosis that was hospitalized at the IV Neurosurgery Clinic of TEHBA in January 2019 and suffered a re-intervention for removal of the spinal cord tumor (psammomatous meningioma) and with spinal cord decompression. In our clinic, the patient was admitted for incomplete AIS/Frankel C paraplegia, he had initially followed a complex nursing program and subsequently a rehabilitation adequate program. The patient was assessed functionally using the following scales: AIS / Frankel, modified Ashworth, Functional Independence Measure (FIM), Life Quality Assessment (QOL), FAC International Scale, Independence Assessment Scale in Daily Activities (ADL / IADL), Walking Scale for Spinal Cord Injury (WISCI).

Results: The paraclinical assessments (cerebral and spinal cord MRI) detect multiple cerebral tumors and micro-nodules adjacent to the lumbar spinal roots, which, associated with the bilateral acoustic neurinoma (diagnosed in 2013), contributed to the suspicion of the NF2 diagnosis. The patient had two admissions in our clinic division, benefited from a complex neuro-muscular rehabilitation program, having a favourable evolution, with an increase in the evaluated scales scores, now performing walking with a support from another person in walking frame, as well as sphincter re-education, with the neurogenic bladder remission.

Conclusions: Even if there is no cure for neurofibromatosis and no standard treatment, it is important to promptly diagnose such a rare disease and to give an adequate treatment (AINS or other analgesic drugs, surgery, chemotherapy or radiation -when it's needed, or psychotherapy) for controlling symptoms and also a personalized rehabilitation program (including nursing measures) enhancing including patient's quality of life.

Key words: paraplegia, neurofibromatosis, neuro-muscular rehabilitation

Selected bibliography:

1. Ferner RE, Huson SM, Thomas N, Moss C, Willshaw H, Evans DG, Upadhyaya M, Towers R, Gleeson M, Steiger C, Kirby A - Guidelines for the diagnosis and management of individuals with neurofibromatosis 1, Med Genet 2007;44:81-88. doi: 10.1136/jmg.2006.045906

2. Smith MJ, Bowers NL, Bulman M, Gokhale C, Wallace AJ, King AT, Lloyd SK, Rutherford SA, Hammerbeck-Ward CL, Freeman SR, Evans DG. Revisiting neurofibromatosis type 2 diagnostic criteria to exclude LZTR1-related schwannomatosis Neurology. 2017 Jan 3;88(1):87-92. doi: 10.1212/WNL.0000000000003418. Epub 2016 Nov 16.

3. Ropper AH, Samuels MA, Klein JP. Adams and Victor's Principles of Neurology, Chapter 38. Developmental Diseases of the Nervous System 10 edition. page 1013,1023

4. https://rarediseases.org/rare-diseases/neurofibromatosis-2/ 
L42 - Research on neurorehabilitation results in vertebro-medullary post-traumatic conditions associating fractures, in a politramatic context

\author{
Cristina Octaviana DAIA ${ }^{1,2}$, Alina-Elena GHERGHICEANU ${ }^{1}$, \\ Helene IVAN ${ }^{1}$, Gelu ONOSE ${ }^{1,2}$ \\ Corresponding author: Alina-Elena Gherghiceanu: alinaghr.ag@gmail.com
}

\begin{abstract}

\section{Introduction}

Polytrauma is considered to be an array of traumatic injuries, of which at least one is directly life-threatening. In another deffinition, polytrauma refers to the existence of two or more organ and / or system impairments, one of which is life-threatening, leading to physical, cognitive, psychological, psychosocial and consecutive functional disabilities, all requiring a complex and long-lasting rehabilitation program. The essential condition for polytrauma is the existence of a severe damage that involves one of the vital functions of the body. The first aim of this paper is to evidence the functional benefit of the specific rehabilitation program of patients with polytrauma, mainly associated with spinal cord injury (SCI) and other fractures.
\end{abstract}

\title{
Materials and method
}

We performed a retrospective analysis of 68 patients having their consent and The Theaching Emergency Hospital "Bagdasar-Arseni" ethics Committee approval, N.O. 684/21.02.2019. Patients were admitted to the Neuro-Muscular Rehabilitation Clinic Division, between October 2017 and May 2019 between the ages of 19 and 79, divided into two lots of 34 patients: the study group, composed by patients with SCI and associated fractures and the control group composed by patients who had only SCI.

\section{Results}

The level of severity is much higher in the study group, which includes AIS A patients (38\%) and AIS C (29\%), than the control group composed mostly by incomplete patients - AIS D (41\%) and C (26\%). The FIM average at admission and discharge is statistically significantly lower in the study group compared with the control group both at admission $(25.05$ versus $42.29 ; \mathrm{p}=0.001)$ and at discharge $(38.47$ vs. $55.55 ; \mathrm{P}=0.009)$.

\section{Conclusions}

Spinal cord injury in combination with multiple fractures is a negative functioning prognostic factor, both before and after the rehabilitation program. 
L43 - Medical-rehabilitation endeavors, care interventions and connotations of a medicosocial type, in a complex polypathological case: paraplegia, spondylodiscitis, kidney

failure in the haemodialysis stage and bilateral nephrostomies after surgicaly treatted bladder neoplasm.

Corresponding author: Ali-Osman Saglam, E-mail: aliosmansaglam1@gmail.com

1. Teaching Emergency Hospital "Bagdasar-Arseni” Bucharest

2. University of Medicine and Pharmacy "Carol Davila" in Bucharest, Romania

\begin{abstract}
Introduction. Paraplegia or paralysis of lower extremities is caused mainly by disorders of the spinal cord and cauda equina. They are classified as traumatic and non traumatic. Non traumatic paraplegia has multiple causes such as cancer, infection, intervertebral disc disease, vertebral injury and spinal cord vascular disease. The current case report presents the case of a male patients with paraplegia related to the thoracic spondylodiscitis in a patient on haemodialysis.

Materials and methods. Having the patient's consent and The Teaching Emergency Hospital "BagdasarArseni" Ethics Committee's approval, N.O. 17464/14.06.2019, a 72 years old patient, which known with operated bladder neoplasm (2015-neobladder), Chronic kidney failure in haemodialysis program and spondylodiscitis T10-T11 operated in 29.12.2018

Results and discussions. The patient improved on most of the assessment scales/scores implemented in our clinic's Division Motor FIM ( Functional İndependence Measure) from 43/91 to 54/91, FAC (Functional Ambulation Categories) from 85/100 to 92/100.

Conclusions. İnfectious diseases are important causes of non-traumatic paraplegia.

The risk of infection on haemodialysis patient is further increased because of frequent routine skin penetration for venipuncture and operative procedures such as placement of venous catheters and vascular grafts.
\end{abstract}

Key words. paraplegia, haemodialysis, spondylodiscitis, neoplasm, nephrostomy 


\begin{abstract}
Introduction. Medical rehabilitation treatment in pregnancy is currently a highly discussed and controversial topic. Given pregnancy, although the literature recommends increased caution at least in the first trimester, we will not use any pharmacological measure as rehabilitation physicians, regardless of the the moment of pregnancy. Decisions on the medical treatment of any kind, belong to the gynecologist or, as the case may be, in close collaboration with him. We will use only those means that do not influence or increase intra-abdominal pressure, which does not involve electrical procedures near the abdominal cavity, hydrotherapy procedures in special designed pools, without thermal water that has radioactive properties, at a temperature arround $36^{\circ}$ C.
\end{abstract}

Objectives. The purpose of this presentation is to give a therapeutic alternative to medical rehabilitation doctors, as we know that pregnancy contraindicates most of the alternatives of symptomatic treatment (antialgic, antiinflammatory), highlighting the significant importance and role of the rehabilitation physician in the management of lumbar discopathy in pregnancy. We also want to highlight the need for further training and also training a team in each rehabilitation hospital to address this large number of patients.

Materials and methods. We present, along with literature data of the incidence of this pathology in the pregnant patient, treatment alternatives, indications and contraindications, the case of a 23-year-old patient with a 24 weeks pregnacy, presented for treatment at the Rehabilitation Hospital in Baile Felix. This symptomatology was specific to a lumbar discogenic syndrome, with radiculgia, vertiginous syndrome, asthenia, fatigability, insomnia. From her medical history, we also point that we have associated allergic asthma, but also an important psychogenic component that raises differential diagnosis problems. Therefore, medical rehabilitation treatment was recommended, consisting of the following procedures: hydrokinesiotherapy, gym kinesiotherapy, and electrotherapy procedures, strictly observing the contraindications. Associated we also indicated psychological counseling.

Results. Following the rehabilitation program, the patient's progression was favorable, continued therapy offers the possibility of improving the quality of life during pregnancy, which although is a physiological condition, but usually comes with the symptoms of the underlying diseases and also with increase symptomathology . To assess the quality of life before and after treatment, we used the RDQ (Roland-Morris Disability Questionnaire (RDQ) and Quebec Back Pain Disability Scale (QBPDS) questionnaires.

Conclusions. The rehabilitation and physical therapy program that we applied, improved the algodysfunctional syndrome, increased physical and mental tone. Thus, we can point the importance of our specialty in cases of pregnant patients with lumbar discopathy, as well as the necessity of a team to deal specifically with this category of patients. 
L45 - Charcot Marie Tooth disease. Case presentation.

\author{
Elena Silvia SHELBY ${ }^{1}$, Mihaela AXENTE ${ }^{1}$, Liliana PĂDURE ${ }^{1,2}$
}

Corresponding author: Elena Silvia POPESCU, E-mail: $\underline{\text { silviajdx@yahoo.com }}$

1. "The National Teaching Center for Neuropsychomotor Rehabilitation in Children Dr. Nicolae Robănescu",

2. Carol Davila University of Medicine and Pharmacy, Bucharest, Romania

\begin{abstract}
Introduction. This presentation features two clinical cases from the,, Dr. Nicolae Robănescu National Teaching Center for Neuropsychomotor Rehabilitation in Children" as well as a brief presentation of this syndrome. Each of the patients has been admitted for two weeks, in April and May 2019, respectively, for clinical evaluation and physical rehabilitation. Based on a thorough anamnesis focused on the family and medical history, a detailed physical exam as well as paraclinic tests, with focus on the electromyography results, both patients were suspicioned to have type 1 Charcot Marie Tooth disease. Biological samples (blood) were collected from the patients for genetic tests. Both patients presented the duplication of the PMP22 gene on chromosome 17, which has genetically confirmed the diagnosis of type 1 Charcot Marie Tooth disease.

Material and method. The electromyography and biochemical exams were analysed. A detailed anamnesis focused on the patient's birth history, family and medical history has been taken, a thorough clinical exam has been performed. After obtaining the parental consent, blood has been sent to the Dolj Regional Center of Medical Genetics (Craiova), where the patients could benefit from free genetic testing (17p12 chromosomal region).

Results and discussions. Based on the patient's birth history, family and medical history and on the clinical exams, we have raised the suspicion of type 1 Charcot Marie Tooth disease. MLPA analysis for the $17 \mathrm{p} 12$ chromosomal region has genetically confirmed the diagnosis in both cases.

Conclusions: Any patient with electromyography results of type 1 motor and sensory neuropathy and clinical phenotype of foot deformation consisting in foot drop, high plantar arch, hammertoe, ,inverted champagne bottle" shape of the legs, lack of sensation and muscular weakness which debuts in the lower limbs and progresses to upper limbs should be suspected of type 1 Charcot Marie Tooth disease.
\end{abstract}

Key words: Charcot Marie tooth, PMP22, type 1 motor and sensory neuropathy 
L46 - Genetic diseases which require physical rehabilitation

\author{
Elena Silvia SHELBY ${ }^{1}$, Mihaela AXENTE ${ }^{1}$, Liliana PĂDURE ${ }^{1,2}$
}

Corresponding author: Elena Silvia POPESCU, E-mail: silviajdx@yahoo.com

1. "The National Teaching Center for Neuropsychomotor Rehabilitation in Children Dr. Nicolae Robănescu"

2. Carol Davila University of Medicine and Pharmacy, Bucharest, Romania

\begin{abstract}
Introduction. Rare genetic syndromes often pass unrecognized. Gaining knowledge on the phenotype and genetic mechanisms of the disease can be useful to medical practitioners.

Material and method. This case presentation features six short descriptions of genetic syndromes which require physical rehabilitation for recovery, namely Duchenne muscular dystrophy, Becker muscular dystrophy, Down syndrome, Klinefelter syndrome, osteogenesis imperfecta and fragile X syndrome. For each syndrome, the phenotype and genetic cause have been described.

Results and discussions. The syndromes have been explained in detail, with pictures and numerous references.

Conclusions. Expanding the knowledge on rare genetic syndromes which require kinetotherapy procedures is useful for both physicians and kinetotherapists.

Key words: Duchenne muscular dystrophy, Becker muscular dystrophy, Down syndrome, Klinefelter syndrome, osteogenesis imperfecta, fragile X syndrome.
\end{abstract}


L47 - Clinical-therapeutic and recuperatory features in a patient with pluripatology: ischemic stroke, ischemic heart disease (sechelar myocardial infarction), chronic kidney disease and monstrous gout- Case presentation

\title{
Simona-Isabelle STOICA ${ }^{1}$, Carmen Elena CHIPĂRUȘ ${ }^{2}$, Magdalena Vasilica LAPADAT ${ }^{3}$, George PĂTRAȘCU ${ }^{4}$, Gelu ONOSE
}

1, 2, 3, 4, 5- Teaching Emergency Hospital „Bagdasar Arseni” Bucharest (TEHBA) 1,5- University of Medicine and Pharmacy „Carol Davila” (UMPCD) Bucharest, Romania

\begin{abstract}

\section{Introduction}

Gout is a chronic inflammatory arthropathy produced by depositing crystals of monosodium uric acid (in joints and tissues) following an anomaly (genetics or acquired) in the purine metabolism ${ }^{(1,2)}$. The manifestations of the disease are: hyperuricemia, recurrent episodes of acute arthritis, the presence of tophi, chronic kidney disease, urinary lithiasis ${ }^{(2)}$. Stroke represents, the rapid development of localized or global clinical signs of cerebral dysfunction with symptoms exceeding 24 hours, leading to death, without any other cause, except for vascular origin". (3)
\end{abstract}

\section{Materials and Methods}

With the permission of the THEBA Ethics Commission ( no.17464/14.06.2019), we will present the clinical case of a 57-year-old patient admitted to the TEHBA Neuromuscular Recovery Clinic presenting a right hemiplegia and mixed aphasia after an ischemic stroke in the territory of the left middle cerebral artery, on the background of complex polypathology (monstrous gout arthropathy, chronic smoking, arterial hypertension, myocardial infarction with coronary artery stenosis, chronic kidney disease).

\section{Results}

The patient did in our clinic a neuro-muscular recovery treatment, adapted to his needs,which consisted of kinetotherapy and speech therapy and received appropriate medical treatment. The clinical evolution of the patient was slowly favorable, with improvement in language disorders and motor control of paralyzed limbs.

\section{Conclusions}

The case of this patient has several particularities. This is a patient with a vicious life style, with a severe arthropathy, with severe cardio-vascular sufferers, hospitalized for recovering neuro-muscular deficits after an ischemic stroke. Despite limited prognosis, the patient has improved ADL and the quality of life after recovery treatment.

\section{Bibliography}

1. Pisaniello HL, Lester S, Gonzalez-Chica D, et al. Gout prevalence and predictors of urate-lowering therapy use: results from a population-based study. Arthritis Res Ther. 2018;20(1):143. Published 2018 Jul 11. doi:10.1186/s13075-018-1633-9

2. Gherasim L et al. Medicina Interna Ed aIIa, vol 2, Ed Medicala, Bucuresti 2003

G.Onose et al- Compendiu de Neuroreabilitare la adulți, copii și vârstnici, 2008, Ed.Universitară „Carol Davila", București 


\title{
L48 - PATHOPHYSIOLOGY OF ATHEROGENESIS AND CARDIOVASCULAR RISK IN CHRONIC INFLAMMATORY DISEASES
}

Eugen BITERE ${ }^{1}$, Mihaiela CHICU ${ }^{2}$

Corresponding author: Mihaiela CHICU

\begin{abstract}

\section{Introduction}

Chronic diseases are responsible for approx. 38 million deaths annually and approx. $70 \%$ of all deaths worldwide (according to WHO data centralized in 2014). Of these, cardiovascular diseases, cancer, chronic respiratory diseases and diabetes are the leading causes of death. As the role of inflammation in cardiovascular disease has been elucidated, it highlighted the fact that systemic inflammation from autoimmune diseases that started on articular, cutaneous, or digestive mucosal can accelerate the atherosclerotic process, may cause atherothrombotic complications and increase cardiovascular risk.
\end{abstract}

\section{Material and method}

Considering that the latest report of the American Heart Association in 2018 predicts that in the near future there will be approx. 720,000 acute myocardial infarctions per year and 335,000 other subjects will develop a recurrent coronary event, it is necessary to identify the main risk factors that contribute to the early establishment of atherosclerosis phenomena.

Currently, atherosclerosis is considered a chronic inflammatory disease of the arterial wall. Cardiovascular risk factors, namely dyslipidemia, diabetes, smoking, hypertension, obesity and unhealthy diet are associated not only with cardiac but also with neoplastic diseases.

Whatever is the precipitating factor of inflammation in atherogenesis, it causes a procoagulant, systemic prothrombotic status. At the same time, some mediators released by the thrombocyte: PDGF, PAI-1, thromboxane, thrombin and fibrin have a pro-inflammatory effect.

The inflammasome NLRP3, as well as IL1 $\beta$ and IL18, are elevated in unstable atherosclerotic plaques, compared to stable ones.

Antidiabetic medication such as SGLT2 inhibitors reduces the inflammatory process, and reduces cardiovascular risk.

NLRP3 is considered both a marker and a potential therapeutic target for the prevention of tissue lesions in HTA.

\section{Conclusions}

Cardiovascular risk is increased in all autoimmune diseases by accelerating the phenomenon of atherosclerosis due to systemic inflammation. Subclinical atherosclerosis is commonly found in these diseases and is considered an argument for increased cardiovascular risk.

Key words: ATHEROSCLEROSIS, ATHEROMATOSIS, PDGF, PAI-1. 
L49 - The impact of active kinetic programs on clinical and functional status adressed to people with diabetic angiopathy

\title{
Victoria CHIHAI ${ }^{1}$, Alisa TĂBÎRȚ ${ }^{4}{ }^{1}$, Anastasia ROTĂREANU ${ }^{1}$, Vladlena MIHAILOV ${ }^{1}$, Mihail CÎRÎM ${ }^{1}$
}

Corresponding author: Victoria Chihai, E-mail: victoria.chihai@usmf.md,

1. State Univesity of Medicine and Pharmacy "Nicolae Testemitanu”, Chișinău, Republic of Moldova

\begin{abstract}
Introduction. Peripheral angiopathy is one of the most severe complications of diabetes with significant worsening of the general condition and quality of life for individuals. Early onset of this clinical manifestations develop at a rate of $4 \%$ in the period of 5 years after the certain establishment of diabetes diagnosis. Severe progression with uncontrolled glycemic values leads to the development of vascular complications in $15 \%$ of cases after a period of 20 years of illness.

Purpose: To evaluate the impact of rehabilitation programs that include active kinetic techniques on clinical and functional status and quality of life in patients with diabetic angiopathy.

Material and methods. The study included the evaluation of 44 persons with diabetic angiopathy and randomized division of the sample in two groups. The control group (23 patients) underwent conventional treatment (drug and electrotherapy). In patients from study group (21 patients) conventional treatment was associated with Bürger kinetic technique. The effectiveness of the applied programs was analyzed by assessing the clinical-functional status (pain, ankle circumference) and quality of life according to WOMAC scale before and after 3 months. Bürger technique was administrated in 3 sessions daily with conventional treatment during 10 days at in-patient level followed by recommended out-patient program during 3 months. Study results were statistically analysed.

Results: Follow up after 3 months rehabilitation treatment of the study group showed average ankle circumference decrease from $24.4 \pm 0.1 \mathrm{~cm}$ to $21.2 \pm 0.2 \mathrm{~cm}(\mathrm{p}<0.01)$. WOMAC index score revealed a decrease of final summative values from $67,4 \pm 0.2$ points to $65.6 \pm 0.31$ points. The control group recorded regression of the vascular swollen measured by mean ankle circumference from $23.8 \pm 0.1 \mathrm{~cm}$ to $22.6 \pm 0.2$ $\mathrm{cm}(\mathrm{p}<0.01)$ and the WOMAC quality of life scores showed a decrease from $78.3 \pm 0.4$ points to $69.04 \pm 0.3$ points $(\mathrm{p}<0.1)$. Total WOMAC score indicated a significant functional improvement in $14.95 \%$ patients from study group in comparison with $8.19 \%$ of patients from control group.

Conclusions: Bürger kinetic technique associated with conventional treatment in patients with diabetic angiopathy shows the better results of their rehabilitation and quality of life.
\end{abstract}

Key words: Diabetic angiopathy, quality of life, active kinetic techniques, medical rehabilitation programs. 


\title{
L50 - The impact of cognitive decline on stroke rehabilitation
}

\author{
Ana-Maria Fătu', Ana Maria Pâslaru', Valerica Creangă-Zărnescu ${ }^{1}$, Alexandru Nechifor ${ }^{2}$, \\ Mădălina Verenca ${ }^{1,3}$, Mihaela Lungu ${ }^{1,4}$, Anamaria
}

Corresponding author: Ana Maria Pâslaru, E-mail: annapaslaru@gmail.com

1 "Dunarea de Jos" University, Galati, Romania

2 "Carol Davila" University of Medicine and Pharmacy, Bucharest, Romania

3 Clinical Emergency Hospital for Children "Sf.Ioan" , Department Rehabilitation, Galati, Romania 4 Clinical Emergency Hospital "Sf. Apostol Andrei", Department Neurology, Galati, Romania 5 Psychiatry Hospital "Elisabeta Doamna", Galati, Romania

\begin{abstract}
Introduction. Stroke is a disease of great public importance, the second leading cause of death and the third leading cause of disability. The persistent and progressive decline of cognitive function in stroke survivors has a major impact on the patient's health and quality of life, with repercussions affecting the whole society. There is no cure for cognitive impairment or dementia, apart from the non pharmacological treatment: the rehabilitation, which may be an important effective alternative.

Materials and methods. The study was retrospective for a period of 6 months. The patient population consisted of 60 individuals. Their primary diagnosis was stroke and the secondary being dementia. Patient assessment was done by clinical, imagistic and psychiatric examination. In addition, an analysis of randomized controlled data trials from the literature, on cognitive rehabilitation had been performed.

Results and discussions. The results show that $58 \%$ of patients were diagnosed with mixed dementia and $61 \%$ had this diagnosis before brain damage occured, with a Mini Mental State Examination under 20 points. The most common disorders of cognition were: fixation hipomnesia, temporal-spatial disorientation, impaired computing. Dementia patients have different rehabilitation needs and associate a lower functional result than those without cognitive impairments. For a rehabilitation benefit patients should be able to recover their skills step by step and carry them over to the next session, wich is difficult for people with severe memory problems. They have a low potential for progress and require a long time and many resources to advance with neurorehabilitation.

Conclusions. The brain injury, such as stroke, causes damage of motor and cognitive functions with repercussion on quality of life. The cognitive decline associated with stroke is an important aspect of neurorehabilitation. Nevertheless is slightly neglected to the detriment of physical disability as there is a lack of recovery potential in these patients.
\end{abstract}

Key words: dementia, stroke, cognitive, neurorehabilitation 


\title{
L51 - THE USE OF TRINITY AMPUTATION AND PROSTHESIS EXPERIENCE SCALES IN THE COMPLEX REHABILITATION OF PERSONS WITH LOWER LIBM AMPUTATION
}

\author{
Alisa TĂBÎRȚ $\breve{A}^{1,2}$, Victoria CHIHAI $^{1}$
}

Corresponding author: Alisa TĂBîRȚĂ, E-mail: alisa.tabirta@usmf.md,

\begin{abstract}
Introduction. Assessing the quality of life of people who have suffered limb amputations should be multidimensional focusing on physical, functional and mental health, and social engagement. Activiy of daily living and level of social participation is largely determined by the possibility of ambulance. The study of the speciality literature highlighted the use of life quality assessment scales in people with amputation by applying generic and specific tools under stationary and home conditions related to prosthetic-orthopedic care and less correlated with rehabilitation programs.
\end{abstract}

Material and methods. In the prospective clinical study, comparatives included mature individuals with unilateral transtibial amputations with diabet ( $\mathrm{n}=142$ persons) with random division in two study groups (test group-72 persons, control group-70 persons). Both groups received prosthetic care. The test group was included in active rehabilitation programs - active physical therapy, assisted active therapy, posture, manual massage, local electrotherapy in stationary conditions with continuation of secondary kinetoprophylaxis programs at home for 6 months. The evaluation of the quality of life by applying Trinity Amputation and Prosthesis Experience Scales (TAPES) was carried out after one and 6 months with the establishment of four areas of analysis: Self-assessment of health status; Evaluation of the degree of adaptation to the prosthesis; Evaluating of daily activities; Assessing the psychoemotional impact.

Results. The self-assessment of the health status referred to as "agreement" after 6 months in the test group was $98,6 \%$ compared to $67,1 \%$ in the control group $(p<0,05)$ and is marked by the presence of dolor syndrome or concomitant pathologies. After 6 months in the test group, about $60 \%$ had only 1-2 episodes of pain weekly - about $15 \%$ less compared to the control group with a mean dentine wearing duration of $6,1 \pm 1,90$ hours in the group - control and up to $8,8 \pm 2,58$ hours in the test lot. The dynamics of the psychoemotional status in the test group $(81,0 \%)$ versus the control group $(28,9 \%), \mathrm{p}<0,05$, recorded after 6 months, was directly proportional to the functional performance. Improvement of the quality of life was personalized by the acceptance of the physical and functional situation by persons with transtibial amputation $(34,5 \%$ in the test group versus $22,7 \%$ in the control group), with restrictions in interaction with the social environment during the and the quality of the work performed (with $40 \%$ functional restrictions for the test group vs $27 \%$ control group, $\mathrm{p}<0,01)$.

Conclusions. The complex medical rehabilitation programs had considerably influenced the functional, psychosocial status and the level of participation of people with lower limb amputations. The Trinity Amputation and Prosthesis Experience Scales (TAPES) can be applied in assessing the quality of life of people with lower limb amputations to assess the effectiveness of rehabilitation programs in prospective comparative studies.

\section{References.}

1. Gallagher P., Deirdre D., MacLachlan M. Psychoprosthetics. London: Springer-Verlag, 2008. 165 p.

2. Bena J.F. Lower Extremity Amputations: Factors Associated With Mortality Or Contralateral Amputation. In: End Surg, 2013, vol. 47, nr. 8, p. 608-613.

3. Carolin E. Horne. Quality of Life in Patients with Prothetic Legs: A Comparison Study. In: J Proth and Ortho, 2009, vol. 21, nr. 3, p. 154-159. 


\title{
L52 - STUDY ON EFFICIENCY OF ELECTROTHERAPY AND PHYSIOTHEAPY MANAGEMENT ON HERNIATED LUMBAR DISC
}

Ilie Onu, Mariana Rotariu, Elvina Mihalaş, Călin Corciovă

Corresponding author: Ilie Onu, E-mail: elipetromed@yahoo.com

\begin{abstract}
Introduction. Lumbar Disc Herniation (LDH) is a focal disorder of the lumbar intervertebral disc, below 25\% of its circumference. As any impairment of an LDH anatomical structure produces local pain, with or without irradiation on the inferior limb, scoliosis, limiting mobility and decreasing muscle strength, etc. Electrotherapy and physiotherapy are non-invasive therapy with significant effects in the short and medium term in reducing LDH symptoms and regaining the static and dynamic features of the lumbar spine.

Material and method. The study was conducted in the Piatra Neamt Micromedica Clinic on two groups of patients diagnosed with LDH, with lumbar radicular syndrome, aged 30-59 years. The study assesses the level of pain relief both during physiotherapy and electrotherapy sessions, and 30 days after they finished. The pilot group consisted of 22 patients who underwent a complex electrotherapy program of 10 sessions: TENS currents, interferential currents applied longitudinally to the affected limb, LASER, ultrasound, and Williams first stage of physiotherapy program. The control group consisted of 25 patients who performed the electrotherapy protocol identical to the pilot group, and the physiotherapy program was McKenzie type. Eligible patients were those with VAS 5-6, with LDH of L5 - S1 radiculopathy, who had supportive medication prior to electro and physiotherapy.

Results and discussions. After the initial evaluation, another intermediary evaluation was made at the 10th session and 30 days respectively at the end of the session. The results obtained were analyzed in terms of indicators: visual analogue scale (VAS) measurement of pain intensity and clinical tests specific to root syndromes. The primary outcome was the decrease in pain intensity in both patient groups. After 30 days of termination, both groups experienced substantial clinical improvements, VAS decreased from 5 to 0 . At ten, McKenzie patients reported a noticeable decrease in pain over those with the Williams program.

Conclusions. Following the analysis of the two groups of patients, we can say that the electrotherapy treatment plan, Williams / McKenzie physiotherapy, greatly reduced the symptoms without using medication. The patients described the McKenzie program as being easy to execute and more effective from the point of view of reducing the pain.
\end{abstract}

Key words: McKenzie, Williams, LDH, electrotherapy, radiculopathy, physiotherapy 


\title{
L53 - Research - Survey to 142 thermalist who have performed a thermal cure at the Baths of Baños de Molgas (Ourense) and Augas Santas (Lugo) - Galicia - Spain
}

\author{
María G. Souto Figueroa ${ }^{1}$, Antonio Freire Magariños $^{2}$
}

1. Dr. Chemical Sciences, Chair of Physics and Chemical, Graduate in Pharmacy, Conseiller Technique de la Sociéte Française de Thermalisme et de Thalassothérapie pour la Santé Bucco-dentaire [Spain] maritasoutofigueroa@gmail.com

2. Dr. specialist in Medical Hydrology, Medical director Augas Santas \& Rio Pambre Spas, Lugo, Spain. afreire@galatermal.net

\begin{abstract}
Introduction. A study was carried out for the first time in a population of 142 thermalist who had undergone a thermal treatment at the spas mentioned with a 12-day stay. For thermalism, efficacy is important, but so is its usefulness, for which four criteria are required: efficacy, the benefit-risk ratio, compared with other treatments of the same conditions, the cost-effectiveness ratio, the specificity

Material and method. The Research-Survey contains 57 questions with multiple answers that make a total of 198 questions.

SURVEY I. Know the number of people who have done or not the first treatment the previous year, as well as its effectiveness. SURVEY II. Know the cartography of this thermal clients, its social and demographic characteristics. SURVEY III. A cure at the spa, the various pathologies they present, their medication, their opinion. SURVEY IV. Specific of Rheumatology.

SURVEY V. Review of the Evolution after the Thermal Cure, carried out 6 months after finishing the treatment.

Results and discussions. $56 \%$ of respondents had already performed a cure the previous year and $24 \%$ had improved significantly. The female sex represents $65 \%$ of the population. The age, more than 60 years, $89 \%$. Regarding the pathology, osteoarthritis of the limbs, knee $66 \%$, hands $54 \%$, osteoarthritis of the vertebrae, cervical $56 \%$. The distance to travel without fatigue or pain is less than 100 meters $37 \%$. The number of floors raised without fatigue, answer none, $37 \%$.

RESULTS SURVEY V: after treatment (among others). A little less pain, 57\%. To the consumption of analgesics and / or NSAIDs, they answer that less, 52\%. To the mobility, walk more distance than before without fatigue, $4 \%$. Walk more time than before without fatigued $8 \%$. Quality of life, subjective assessment, respond better than before, $57 \%$.
\end{abstract}

\section{CLASSIFICATION}

Augas Santas Spa: weak mineral water, cold, alkaline, sulfurized.

Baños de Molgas Spa: medium mineralization water, mesothermal, alkaline, lithic, fluorinated, slightly radioactive

Key words: Mineral waters. Thermal cures. Osteoarthritis of the limbs. Consumption of analgesics.

\footnotetext{
Bibliography

1. Roques CF, Queneau P.: Médecines thermales et douleurs des lombalgies, gonarthroses et fibromyalgie. Bull Acd Matle Mèd. 2016; 200: 575-87.

2. Souto Figueroa MG, Pascual Souto MJ.: Enquète sur l'utilitation et l'efficacité de la source du Tinteiro, à Ourense (Espagne). Presse Therm Climat 1994; 131: 194-96.

3. Souto Figueroa MG.: Determinación del Magnesio en las aguas mineromedicinales de la provincia de Ourense para su utilización en sujetos obesos, diabéticos y reumáticos. Bol. Soc. Esp. Hidrol.Méd. (Madrid), Vol.XII, num.2, 1997.
} 


\section{L54 - ACUPUNCTURE IN REHABILITATION - A GENERAL VIEW}

\section{Irina IONICĂ}

RMFB Medical Rehabilitation Center, Bucharest dr.irina.ionica@gmail.com

\section{Abstract}

INTRODUCTION: The paper presents general principles in acupuncture, its indications and mechanisms in several diseases that can be subject of rehabilitation.

\section{MATERIALS \& METHODS:}

Acupuncture, one of the branches of Traditional Chinese Medicine, 5000 years old, is now a complementary

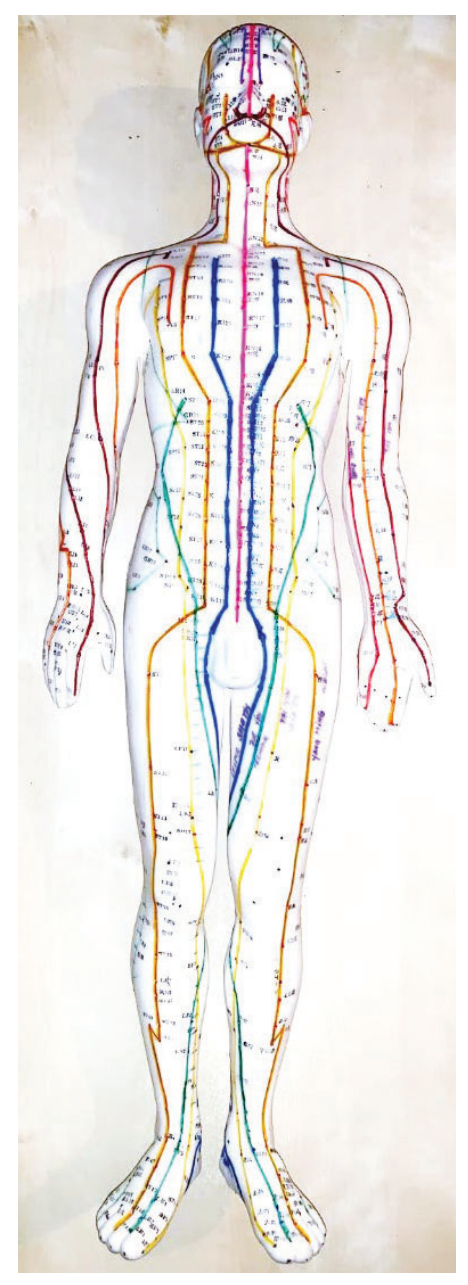
medical practice. Combining the reference system of yin/yang and five elements theory with modern knowledge of physiology, neurophysiology and morphopathology, acupuncture can bring value, in an interdisciplinary manner, to the treatment and prevention of many disorders.

The energetic system of the organism functions as an independent system organized in 12 principal channels, 8 extraordinary channels, 365 points on meridians and many other extrameridional points.

Acupuncture can treat acute and chronic conditions. As a holistic and personalized approach, acupuncture can ease numerous pathologies, with a maximum of benefit in functional stages of disorders. Pain, lack of mobility, allergies, addictions and various emotional conditions can benefit of acupuncture.

Based on many clinical trials, acupuncture is an acute and chronic pain relief method, therefor used in modern rehabilitation facilities.

The classical acupuncture method implies stimulating meridians and points with needles, by tonifying or sedating them. Beside that, there are various other stimulation or sedation methods:

- $\quad$ pressure (acupressure),

- $\quad$ heat (moxibustion),

- $\quad$ cupping,

- $\quad$ solutions administration on acupuncture points (pharmacopuncture, mezotherapy),

- $\quad$ electric stimulation (electroacupuncture),

- $\quad$ light (laser therapy or colored light stimulation),

- $\quad$ ultrasound (sonopuncture),

- $\quad$ electromagnetic field (magnetic therapy).

emphasizes on emotional issues.

The so called "5 Elements" acupuncture is an independent approach and

RESULTS: Acupuncture used in rehabilitation can lead to pain relief, muscular force increase, ROM improvement, and decrease of stress associated to disease.

CONCLUSIONS: Acupuncture can be used as a complementary method in medical rehabilitation, for faster results and better life quality of patients. 


\title{
L55 - The health benefits of Finnish sauna bathing
}

\author{
Denisa COAJÄ $\breve{1}^{1}$, Gabriela DOGARU $^{12}$
}

Corresponding author: Denisa Coaja, email: coaja.denisa@gmail.com

1. Clinical Rehabilitation Hospital, Cluj-Napoca, Romania

2. "Iuliu Haţieganu" University of Medicine and Pharmacy Cluj-Napoca, Romania, Department of Medical Rehabilitation

\begin{abstract}
Introduction. There is more and more evidence that passive heat therapy (sauna or the use of hot tubs) has numerous beneficial health benefits. Sauna-bathing, especially the Finnish sauna, is gaining popularity all over the world. This ancient tradition, with deep roots in the culture of Finland, has been used for wellness, pleasure and psychological benefits (relaxation, enhanced resistance against stress). The up-to-date scientific literature has brought to light that sauna may also be associated with several health benefits: the reduction in the risk of vascular diseases such as high blood pressure, cardiovascular disease, and neurocognitive diseases (reduction in the risk of stroke); nonvascular conditions such as pulmonary diseases; as well as amelioration of conditions such as arthritis, headache, and flu. The pathophysiology behind these benefits resides in that the regular sauna bathing may ameliorate the endothelium-dependent dilatation, which would lead to reduced arterial stiffness and therefore lower systemic blood pressure. There has also been postulated a beneficial effect on the circulating lipid profiles and on the modulation of the autonomic nervous system.

Material and methods. This paper sums up the existent evidence on the role of Finnish sauna on various diseases including cardiovascular, neurological and pulmonary conditions based on several observational studies, randomized controlled trials(RCT) and non-RCTs from PubMed, MEDLINE and EMBASE. The literature was selected using search-terms as sauna bath, sauna benefits, Finnish sauna, coronary heart disease, heart failure, hypertension, depression, dementia, stroke, arterial stiffness. The emphasis was on traditional Finnish sauna baths because they are the most studied.

Results. Finnish sauna bathing definitely has some health advantages, including cardiovascular, neurological, neurocognitive, psychological and pulmonary benefits. Conclusions. It should be considered in specific cases, for improving the overall well-being of the patients.
\end{abstract}

Key words: sauna, Finnish sauna bathing, cardiovascular benefits, neurological benefits, pulmonary benefits, wellness, well-being; 


\title{
L56 - Spina bifida - functional rehabilitation methods in children
}

\author{
Otilia Rogoveanu$^{1}$, Gherghina Florin ${ }^{1}$, Rodica Traistaru ${ }^{1}$
}

\begin{abstract}
Introduction:

Spina bifida is a congenital bone malformation of the vertebral column, due to the incomplete development of the neural tube which can determine neurological and severe osteoarticular sequelae.

Objective

The aim of this study is to apply certain rehabilitation techniques in order to improve the functional performances of a child diagnosed with spina bifida.

\section{Material and methods}

We present the case of a child diagnosed at birth with lumbosacral myelomeningocele (L3-S1), flaccid paraparesis, hydrocephalus and neurogenic bladder, who underwent surgery 4 days after birth. The neurologic tests at 9 months after birth revealed the absence of distal motor function, hypoesthesia affecting the L3-L5 dermatomes, diminished muscular force at the level of quadriceps and iliopsoas muscles (F3 right, F2 left) and gluteus muscles (F2).
\end{abstract}

\section{Results}

Rehabilitation treatment was started at the age of 9 months and is continued up to the present day. The kinetic programme included multiple stages according to the evolution of the patient.

The first rehabilitation stage ( 9 months -2 years) included stretching exercises and mobilization of the inferior limbs, as well as muscular electrostimulation.

The second stage of rehabilitation treatment (2-3 years) continued the rehabilitation techniques started in the first phase, but also added isometric exercises and work-out which help stabilize the pelvic muscles.

The third stage of treatment (3-5 years) added the following exercises to the previous techniques: exercises performed with orthotics and exoskeletons. In this phase, the patient had an impressive evolution, being able to walk independently at the age of 4 using walking aids.

Occupational therapy was also started, with very good results in the rehabilitation programme.

\section{Conclusions}

After finalizing the current study, we discovered that early initiation of the physiokinetic therapy programme combined with the use of exoskeletons generated multiple favorable effects, therefore reducing deformities that affect the vertebral column and the inferior limbs. 


\title{
L57 - GEOAGIU BAI RESORT - OUR EXPERIENCE OF MEDICAL REHABILITATION TREATMENT
}

\author{
Mihaela DUTESCU, Raluca OLTEAN, Petru NENADICI
}

Corresponding author: Mihaela DUTESCU, E-mail: mihaela2212@yahoo.gr

\begin{abstract}
Introduction. Along with Herculane and Calan, Geoagiu-Bai enjoys the inalienable privilege of being one of the oldest spas in the country, dating from the Roman colonization period, when the resort was named Termae Dodonae. In the opinion of the specialists, however, the therapeutic use of the sources here is even older, that is, from the era before the colonization, when the locals used thermomineral water that abundantly springs up at Germisara, considered to be toponymic geto-dac ("germ" = hot, hot; "= Water, spring).
\end{abstract}

Materials and methods. The natural therapeutic factors of Geoagiu-Bai resort are: bicarbonate, calcic, magnesium, low-radioactive, hypotonic, hypothermic $\left(29-33^{\circ} \mathrm{C}\right)$ mineral waters with a total mineralization of 1,1-1,4 g / 1; sedative climate bioclimate and ioduros-feruginous peat mud. These natural therapeutic factors are used in the treatment of complex pathologies of the locomotor system (degenerative, inflammatory rheumatism, post-traumatic and postoperative pathology), respiratory, dermatological, neurological and dismetabolic disorders. The treatment bases in the resort are using therapeutic procedures to supplement the therapy with natural climate factors such as electrotherapy, hydrotherapy, hydrokinetotherapy, thermotherapy, magnetotherapy, laser therapy, inhalotherapy and massage.

The duration of treatment course at the Germisara Hotel Resort \& Spa is 5 and 10 days, respectively, during which patients benefit from a complex medical treatment including the combination of natural cure and electrotherapy procedures, laser therapy, magnetotherapy, hydrokineotherapy and massage.

Results. Following treatment, we gained an increase in joint mobility and a significant pain relief especially in the degenerative, posttraumatic and postoperative pathology of the locomotor system. We also found that there was an significaly increased number of patients treated in our facility during 2018-2019.

Conclusions. Combining natural climate factors in Geoagu-Bai with specific rehabilitation procedures has an important role in the treatment and prevention of multiple pathologies; we also highlight the need to update the studies made over time and to supplement them with new data to support the effectiveness and importance of natural climate treatment. 


\title{
L58 - The meteorological complex and the human pathology. Case study - Suceava county
}

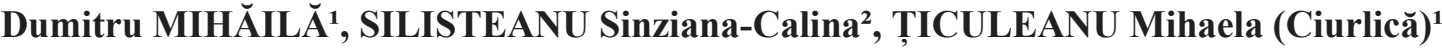

Coresponding author: Sinziana Silisteanu, E-mail: sinzi silisteanu@yahoo.com

${ }^{1}$ Geography Department, USV (University of Suceava ), ${ }^{2}$ Specialty Ambulatory CF Suceava, FEFS (Faculty of Physical Education and Sport), DSDU USV (University of Suceava )

\begin{abstract}
Introduction - Providing with the best health level for humans depends in different degrees on the interaction between the man and the elements, factors or parameters of the environment condition (water, air, temperature, humidity, pressure). It is very important to know the risk factors of the environment (main pollution or accidental air pollution, the sudden ample changes of weather, the excessive exposure to sunrays), it is an important component that helps maintaining and continuing the health condition.
\end{abstract}

The objective of this trial is to evaluate the impact of the environment factors upon the health condition of the inhabitants in a district of Suceava town.

Material and method - We monitored the health condition and the body reaction of the patients seeing a general practitioner, for a period of 3 months, according to the physical

phenomena (temperature, humidity, exposure to cold, wind, atmospheric pressure). We used questionnaires according to which were obtained data that were statistically processed afterwards.

Results and discussions - From the collected and analyzed data, it was found that the increased humidity determins the formation of the acid-type composed, and influences the morbidity by the chronic diseases of the respiratory system and of the cardiovascular one. The change in the composition of the air due to pollution determined the slight diminution of the oxygen percentage in the air and the slight local increase in the percentage of carbonic gases. The consequences of worsening the atmospheric chemistry were: the increase in the frequency and debit at the level of the respiratory system and of the cardiovascular one, the occurrence of dispnea, the sensation of the lack of air, the increase in the blood pressure, polycythemia. Throughout time they may lead to cerebral apoxia, to heart failure or to acute dispnea, by straining the two involved systems. Apart from cardio-respiratory symptoms and neurological failure, the patient may have trouble with keeping the balance, with the neurological coordination, and with the orientation in time and space. Also, the frequency of the mentioned health conditions has increased. The patients who have cardiovascular and respiratory failure face an increased risk to this exposure. It was also recorded the increase in the addressability of the persons with nervous, digestive and metabolic symptomatology as well as neurological failure.

Conclusions - The exposure of patients to the environmental factors may accelerate the evolution of cardiac, respiratory, digestive or neurologic diseases or they may worsen the existence of some of them. The action of these factors is found in time upon all the organs involved in providing a suitable viable and functional status.

Key words: health, meteorological variability, the pollution of the air in Suceava 


\title{
L59 - EFFICACY OF NATURAL THERAPEUTIC FACTORS FROM OCNA SIBIULUI SPA RESORT IN GONARTHROSIS
}

\author{
Mariana VARODI ${ }^{1}$, Gabriela DOGARU ${ }^{2}$
}

Corresponding author: Mariana VARODI, E-mail: nicovarodi bft@yahoo.com

\begin{abstract}
Introduction. Through its multiple natural therapeutic factors like: the sodium-chloride concentrated waters of 52 lakes, fossil sapropelic mud and sedative bioclimate, Ocna Sibiului spa resort offers the possibility of treatment for a wide range of locomotor system diseases from degenerative, inflammatory and abarticular rheumatic diseases to post-traumatic disorders, peripheral neurological diseases, gynecological, dermatological, metabolic or respiratory disorders. Thousands of Romanian and foreign tourists come every year to enjoy treatment and rest in a natural setting favorable to physical and mental regeneration. Although its therapeutic effects have been known since the time of Dacians and Romans, and patients attending treatment feel the beneficial effects on their health, which makes them return year after year, there are no recent studies on the therapeutic efficacy of these natural factors, as would be required in the current context of evidence-based medicine.
\end{abstract}

Objective. Given the predominantly rheumatic profile of the resort and taking into consideration that knee arthrosis affects more than $60 \%$ of persons aged over 60 years, causing pain, limitation of mobility and impairment of quality of life, we conducted a study evaluating the effects of natural therapeutic factors in Ocna Sibiului spa on the clinical and functional parameters of patients with knee arthrosis.

Material and method. In patients diagnosed with gonarthrosis, who attended a 10-day course of treatment in Ocna Sibiului spa consisting of hot mud packs and hydrokinesiotherapy in pools with sodium-chloride concentrated water, we assessed at the beginning and at the end of treatment: pain, using the visual analogue scale, mobility, by goniometry, the Lequesne algofunctional index and WOMAC knee score.

Results. Data analysis shows the beneficial effects of treatment with natural therapeutic factors in Ocna Sibiului for patients with gonarthrosis, with a reduction of pain symptoms, an improvement of mobility, an amelioration of functional capacity and quality of life.

Conclusions. Considering the efficacy of natural therapeutic factors and the high accessibility of therapy, treatment in this spa resort remains an important component of the rehabilitation of patients with gonarthrosis. 


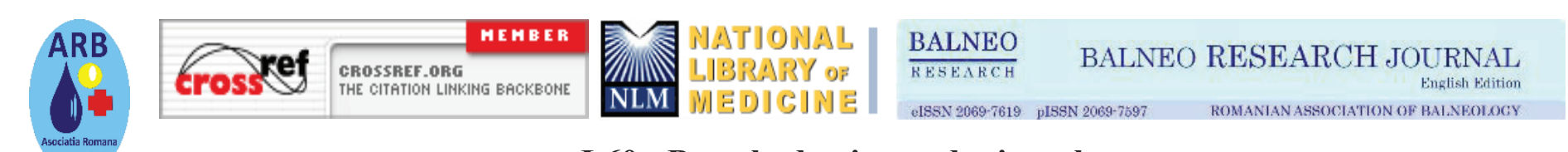

\author{
L60 - Bone hydration and mineral waters \\ Boróka-Panna GÁSPÁR ${ }^{1}$, Gabriela DOGARU ${ }^{2}$
}

Corresponding author: Boróka-Panna Gáspár, E-mail: g.boro@hotmail.com

1. "Prof. Dr. Ioan Puşcaş" City Hospital, Şimleu Silvaniei, Romania 2."Iuliu Haţieganu" University of Medicine and Pharmacy Cluj-Napoca, Romania

\title{
Abstract \\ Introduction.
}

The importance of water compartment in bone architecture is well defined in the scientific literature, and biological effects of "hydration" with mineral waters demonstrate a key role in bone metabolism.

\section{Material and method.}

Several studies, reviews describe and summarize characteristics of water, as one of the main bone component, underline the measurable status and clinical applications. Presenting and highlighting the preventive and treatment role of mineral waters in skeletal diseases, belongs to a balneological approach.

\section{Results and discussions.}

A bone structural component and interfacial agent, water attribute in biomechanical properties, interact in formation, organization of collagen, proteogligans, proteins, contribute in orientation and transport ions, apatite crystals.

Bone composed of a porous matrix fulfill by water, the solid compartment include organic matter and minerals. Studies distinguish two water compartments, one mineral and matrix-bound water and a free form, which located inside pores, also the water mobility within hydroxyapatite pores was demonstrate.

Bone water content is measurable, actually quantification methods like nuclear magnetic resonance ultrashort echo time or microcomputed tomography imaging reveal accuracy of assessing bone microarchitecture and quality. The 3D structure can be affected by age and disease-related variables.

Mineral waters in natural nutritional way influence bone metabolism, certain studies consider bicarbonate rich alkali mineral waters decreasing bone resorption.

\section{Conclusions.}

The hydration status is essential to structural behavior of the bone tissue. Mapping the evidence by imaging methods, the collagen-mineral-water interaction can contribute to an assessment of bone quality, prevent fracture risk.

Key words: water, bone, mineral

\section{References:}

- Granke M, Does MD, Nyman JS. The role of water compartments in the material properties of cortical bone. Calcif Tissue Int. 2015 Sep; 97(3):292-307

- Unal M, Creecy A, Nyman JS. The role of matrix composition in the mechanical behavior of bone. Curr Osteoporos Rep. 2018 Jun; 16(3): 205-215

- Wang Y, Von Euw S et al. Water-mediated structuring of bone apatite. Nut Mater. 2013 Dec;12(12):11441153

- Lu X, Jerban S et al. Three-dimensional ultrashort echo time imaging with tricomponent analysis for human cortical bone. Magn Reson Med. 2019 Jul; 82(1): 348-355

- Nyman JS, Ni Q, Nicolella DP, Wang X. Measurements of mobile and bound water by nuclear magnetic resonance correlate with mechanical properties of bone. Bone. 2008 Jan; 42(1): 193-199

- Burckhardt P. The effect of the alkali load of mineral water on bone metabolism: interventional studies. J Nutr. 2008 Feb; 138(2):435S-437S 


\section{L61 - Correlation of VAS pain score with function at the pacients with temporomandibular osteoarthritis}

Calin BOCHIS ${ }^{1}$, Liviu LAZAR ${ }^{2}$, Horațiu URECHESCU ${ }^{1}$, Carmen NISTOR-CSEPPENTO ${ }^{2}$, Felicia CIOARA ${ }^{2}$, Nicoleta PASCALAU ${ }^{2}$, Alin BOCHIS ${ }^{2}$, Diana IOVANOVICI ${ }^{3}$

Corresponding author: Calin Bochis, E-mail: calin bochis@yahoo.com

1. “Oro-Maxillofacial Surgery Clinic Timisoara

2. "University of Oradea, Faculty of Medicine and Pharmacy 3. UMF Victor Babes Timisoara

\section{Abstract}

Introduction. Persistent dysfunctional temporomandibular (TM) leads to degenerative changes of the TM joint. Clinical manifestations are very varied: from muscle fatigue, pain, mandible mobility, muscle spasm, cramps and crepitation to ankylosis. Objective can be found deviations of the mandible, both static and dynamic, hypotonia of masseter muscles. Treatment needs to be individualized, assuming teamwork. The goals of therapy are: pain reduction, improved mobility, toning of hypotonic muscles. In addition to orthodontic and prosthetic treatment, in TM arthrosis, steroidal, non-steroidal anti-inflammatory drugs, hyaluronic acid infiltrations, analgesic physical therapy (low frequencies, medium frequency and high frequency, laser), kinetotherapy.

Materials and methods. In order to evaluate the effect of electrotherapy and kinetotherapy on TM arthrosis, we conducted a study involving 20 patients with a diagnosis of arthritis TM, who addressed the ambulatory of the Oro-Maxillofacial Surgery Clinic Timisoara between March 2017 and March 2018. Following specialist consultation, the specific treatment recommended, the patients were directed to a medical recovery cabinet to follow a laser tracer, infrared probe, 10 sessions, $18 \mathrm{~J} / \mathrm{cm} 2$ dose, analgesic and biostimulator effect, TENS $140 \mathrm{HZ}, 10 \mathrm{~min}$. with analgesic effect. Physical therapy consisted of active exercises in the axle at the ATM level, repeated 10 times, other with isometric exercises, duration of 4 seconds, associated with local massage. The pain was measured with the VAS scale of 0 to $100 \mathrm{~mm}$, and the function I evaluated with the JLFS-20 scale, which evaluates mastication, mobility and verbal and nonverbal communication. Statistical processing was performed with the SPSS correlation program.

Results and discussions. The average age of patients is 58.6 years, with women predominating, with $59 \%$ of women. The mean value of the initial VAS score is 43.85 , reaching 17.7 at the 21 -day revaluation, resulting in an improvement of $26.15 \%$. The average JLFS score improves by about $10 \%$. Figure 1 and 2 show the concomitant change in pain values with TM function. However, determining the Pearson coefficient $(r=-$ 0,196), which does not have causal significance, shows us, in this case, a weak, negative correlation.

Conclusions. Electrotherapy can be a therapeutic alternative along with mechanotherapy in the treatment of TM arthrosis.

Key words: correlation, pain, function, arthrosis, electrotherapy,

\section{Correlations}

\begin{tabular}{|rl|r|r|}
\hline & & \multicolumn{1}{|c|}{ VAS1 } & \multicolumn{1}{c|}{ JLFS1 } \\
\hline VAS1 & Pearson Correlation & 1 & -.196 \\
& Sig. (2-tailed) & & .407 \\
& N & 20 & 20 \\
\hline JLFS1 & Pearson Correlation & -.196 & 1 \\
& Sig. (2-tailed) & .407 & \\
& N & 20 & 20 \\
\hline
\end{tabular}

Fig. 1. Correlating pain with function at first determination

\section{Correlations}

\begin{tabular}{|rl|r|r|}
\hline & & \multicolumn{1}{|c|}{ VAS2 } & \multicolumn{1}{c|}{ JLFS2 } \\
\hline VAS2 & Pearson Correlation & 1 & -.232 \\
& Sig. (2-tailed) & & .325 \\
& N & 20 & 20 \\
\hline JLFS2 & Pearson Correlation & -.232 & 1 \\
& Sig. (2-tailed) & .325 & \\
& N & 20 & 20 \\
\hline
\end{tabular}

Fig.2.Correlating pain with function at second determination 


\title{
L62 - Radiometric assessment of peloid and salt water used for therapy and balneary treatment from Techirghiol Lake, Romania
}

Marian Romeo CALIN ${ }^{1}$, Ileana RADULESCU ${ }^{1}$, Mihaela Antonina CALIN ${ }^{2}$, Elena Roxana ALMASAN ${ }^{3}$

Corresponding author Marian Romeo CALIN, E-mail: $\underline{\text { rcalin@nipne.ro }}$

${ }^{1}$ Horia Hulubei National Institute for Physics and Nuclear Engineering - IFIN HH, Bucharest-Magurele, Romania

${ }^{2}$ National Institute of Research \& Development for Optoelectronics, INOE 2000,Bucharest, Romania

${ }^{3}$ Techirghiol Balneary and Recovery Sanatorium, Techirghiol, Romania

\begin{abstract}
Introduction

Techirghiol Lake located in the south-east on the side of Romania is known for the therapeutics of high medical and scientific value, where water and peloid has been the subject of numerous studies in the most diverse areas of research.

\section{Materials and methods}

Spectroscopic characterization of peloid and salt samples collected from the Techirghiol Lake, was carried out using different chemical, spectroscopic and analytical techniques namely: XRF, ICP-OES, gross alpha-beta and gamma ray spectrometry. This study assesses natural radioactivity concentrations and the radiologic hazard in peloid and salt samples, from ten area in Techirghiol Lake from Romania
\end{abstract}

\section{Results and discussions}

The natural radionuclides such as ${ }^{238} \mathrm{U},{ }^{226} \mathrm{Ra},{ }^{232} \mathrm{Th}$ and ${ }^{40} \mathrm{~K}$ have been determined by gamma - ray spectrometry. The average activity concentrations were of $0.48 \pm 0.10 \mathrm{~Bq} / \mathrm{kg}$ for ${ }^{238} \mathrm{U}, 0.60 \pm 0.10 \mathrm{~Bq} / \mathrm{kg}$ for ${ }^{226} \mathrm{Ra}, 0.30 \pm 0.08 \mathrm{~Bq} / \mathrm{kg}$ for ${ }^{232} \mathrm{Th}$ and $17.5 \pm 1.3 \mathrm{~Bq} / \mathrm{kg}$ for ${ }^{40} \mathrm{~K}$ for salt water samples. Also, the mean activity concentrations for peloides are: $5.7 \pm 1.0$ for ${ }^{238} \mathrm{U}, 6.85 \pm 1.60 \mathrm{~Bq} / \mathrm{kg}$ for ${ }^{232} \mathrm{Th}, 15.3 \pm 3.7 \mathrm{~Bq} / \mathrm{kg}$ for ${ }^{226} \mathrm{Ra}$ and $95.8 \pm 5.5 \mathrm{~Bq} / \mathrm{kg}$ for ${ }^{40} \mathrm{~K}$.

\section{Conclusions}

The results from this study contribute to the identification of possible contaminants in the salt water and peloid, and their association with the potential ecological and human health risk. In this context, of using salt water and peloid in a relatively long treatment period, several radiological indices have been calculated, to determine if the radionuclide's content can be also harmful to human health. The assessment indicates that humans are not exposed to concentrations of metal contaminants higher than the international recommended values.

Keywords: Pelotherapy, Natural peloid, Natural radioactivity, Salt water, Dose assessment, Techirghiol Lake. 


\title{
L63 - Efficacy of natural therapeutic factors from Baile Govora in bronchial asthma
}

\section{Cristina PETRESCU ${ }^{1}$

\begin{abstract}
Introduction. Băile Govora spa resort is situated in Vâlcea county, at $20 \mathrm{~km}$ from Rm. Vâlcea, on a bypass of the road to Horezu and Tg. Jiu, in the valley of the Hinţa river, like in a funnel, at an altitude between 330 $380 \mathrm{~m}$, in a particularly charming area with hills covered by beech, fir, oak, spruce and acacia forests. Characteristic of this area is the presence of mineral waters, which represent natural therapeutic factors used for the treatment of various disorders. Baile Govora is one of the richest spa resorts in iodine and bromine waters in Europe, iodine and bromine being of organic origin. It has: hypertonic iodine, bromine, sulfur, chlorine, sodium concentrated mineral waters; hypotonic sulfur mineral waters; hypotonic bicarbonate, sulfur, sodium, calcium waters; mineral water springs for crenotherapy; continental climate with Mediterranean influence, relatively constant humidity, temperature without extremes, and low allergenic pollen load.

\section{Material and method}

Case study. Patient P.C. aged 29 years, residing in Baia Mare, diagnosed with bronchial asthma at the age of 20 years, presented to our service 4 years before, with noisy symptoms characteristic of this disorder; in addition, she had cyclic manifestations of allergic rhinitis. Clinically, diminished vesicular murmur, diffuse sibilant rales in the chest area with significantly prolonged expiration, wheezing, marked bronchial spasm; $81 \%$ O2 saturation; exertional dyspnea were present.

After tolerance induction, spa treatment based on inhalation therapy was initiated (with mineral waters, aerotherapy and kinesiotherapy). On day 5 of treatment, O2 saturation increased to $90 \%$ and exercise tolerance also improved. The patient returned for the $7^{\text {th }}$ course of treatment.
\end{abstract}

Results. After the treatment course in the spa resort, the following were found: clinically insignificant stethacoustic changes; good exercise tolerance; $97 \%$ O2 saturation; no characteristic manifestations.

Conclusion. During May-June, vasomotor rhinitis persisted, which was partially therapeutically controlled with Flonidan. 


\title{
L64 - Pulmonary Rehabilitation Saves Lives and Improves Life
}

\section{Paraschiva POSTOLACHE ${ }^{2}$}

Corresponding author: Paraschiva Postolache, E-mail: postpar04@yahoo.com

1,2. "Grigore T. Popa" University of Medicine and Pharmacy, Iasi, Romania

1,2. Clinical Rehabilitation Hospital - Pulmonary Rehabilitation Clinic, Iasi, Romania

\begin{abstract}
Introduction. Pulmonary rehabilitation is recognized as a basic component of chronic pulmonary disease management, being applied as early as possible in exacerbations of these conditions, but also in severe intensive care diseases, and includes lifelong interventions for patients with chronic respiratory disease and involving a dynamic collaboration between patient, family, and healthcare providers. Material and methods. Pulmonary rehabilitation begins in the hospital or in a clinic specialized in pulmonary rehabilitation and continues home. The healthcare team will design an individualized pulmonary rehabilitation plan based on patient needs. The pulmonary rehabilitation program involves patient assessment, physical training, education, nutritional intervention and psychosocial support. Candidates for pulmonary rehabilitation are patients with symptomatic impairment attributable to their respiratory condition. Results and discussions. Patients should be motivated, not have significant transportation problems, and be capable of understanding the purpose and educational content of the program. Contraindications to participation include the lack of motivation, significant cognitive impairment, inability to attend the program consistently, unstable medical conditions that may pose risks, or the inability to participate in an exercise program because of a severe arthritic or other limiting condition. Conclusions. This intervention, integrated into an individualized plan, aims to reduce the symptoms, anxiety and depression, to optimize functional status, to increase participation in routine and social activities, reducing health care costs and to improve the quality of life.
\end{abstract}

Key words: dyspnea, pulmonary rehabilitation, outcome.

\section{References:}

- Alvar A, Bartolome RC, Rongchang C et al. Global Initiative for Chronic Obstructive Lung Disease; Global Strategy for the Diagnosis, Management, and Prevention of Chronic Obstructive Pulmonary Disease (2019 Report). (c) 2019 Global Initiative for Chronic Obstructive Lung Disease, Inc. https://goldcopd.org

- Rochester CL, Vogiatzis I, Holland AE et al. An Official American Thoracic Society / European Respiratory Society Policy Statement: Enhancing Implementation, Use, and Delivery of Pulmonary Rehabilitation. Am J Respir Crit Care Med. 2015; 192(11): 1373-1386. 


\title{
L65 - Assessment of Dyspnea in Pulmonary Rehabilitation Practice
}

\section{Doina-Clementina COJOCARU ${ }^{1}$, Paraschiva POSTOLACHE ${ }^{2}$}

Corresponding author: Paraschiva Postolache, E-mail: postpar04@yahoo.com

1,2. "Grigore T. Popa” University of Medicine and Pharmacy, Iasi, Romania

1,2. Clinical Rehabilitation Hospital - Pulmonary Rehabilitation Clinic, Iasi, Romania

\begin{abstract}
Introduction. Dyspnea is a common symptom of patients with pulmonary diseases and it is, according to American Thoracic Society (2018) a "subjective experience of breathing discomfort" that is a result of interactions among "multiple physiological, psychological, social, and environmental factors". When the symptom lasts for more than 4 to 8 weeks, it is referred as chronic dyspnea. Material and methods. Assessment of dyspnea is necessary as a component of initial diagnosis of the chronic respiratory disease and as clinical outcome of the respiratory rehabilitation program. Anamnesis, one-dimensional instruments (modified Borg dyspnea scale, modified Medical Research Council dyspnea scale), and multidimensional questionnaires (COPD Assessment Test, Chronic Respiratory Disease Questionnaire) are used in daily practice. Results and discussions. In order to fully understand the causes and mechanisms of dyspnea, an accurate clinical examination of respiratory and cardiovascular system as well as a large panel of lab tests, functional tests, and imaging investigations have to be done. Conclusions. Dyspnea is a major complaint of patients with chronic respiratory diseases that can be assessed by subjective and objective methods, being an important outcome of respiratory rehabilitation programs.
\end{abstract}

Key words: dyspnea, pulmonary rehabilitation, outcome.

\section{References:}

1. Baker K, Barsamian J, Leone D et al. Routine dyspnea assessment on unit admission. Am J Nurs. 2013; 113(11): 42-50.

2. Parshall MB, Schwartzstein RM, Adams L et al. An official American Thoracic Society statement: update on the mechanisms, assessment and management of the dyspnea. Am J Respir Crit Care Med. 2012; 185: 435-443. 


\title{
L66 - Heliotherapy, Climatotherapy and Patients with Respiratory Diseases
}

Paraschiva POSTOLACHE ${ }^{1}$, Cristina LACATUSI ${ }^{2}$

Corresponding author: Paraschiva Postolache, E-mail: postpar04@yahoo.com

1,2. "Grigore T. Popa” University of Medicine and Pharmacy, Iasi, Romania

1,2. Clinical Rehabilitation Hospital - Pulmonary Rehabilitation Clinic, Iasi, Romania

\begin{abstract}
Climate therapy is a natural therapeutic factor dependent on local conditions of relief, altitude, climatic parameters and vegetation. This is defined by the sum of climatic characteristics belonging to an area (climatic). The parameters of climate therapy components influences in a positive way the patients with respiratory diseases. It involves the use of different climate types, namely positive climate aspects, for prophylactic and curative purposes as a single method or in combination with balneotherapy and thalassotherapy. Heliotherapy is a natural procedure that uses the therapeutic and healing powers of the sun. Body exposure to beneficial sunlight is recommended for both healthy and suffering people, being appreciated as a simple and free method, but with extraordinary effects in maintaining health. Air, sun, wind, humidity, air pressure and temperature are the stimulating factors of the body. Climate diversity opens up great opportunities for differentiating climate therapy and engaging the body in various climatic conditions. In relation to the state of health, different climate therapy regimens are prescribed, where either a gradual action of climatic factors or active training, or both, predominate.
\end{abstract}

Key words: heliotherapy, climate therapy, respiratory diseases.

\section{References:}

- Götschke J, Mertsch P, Bischof M et al. Perception of climate change in patients with chronic lung disease. PLoS One. 2017 Oct 18; 12(10): e0186632. doi:10.1371/journal.pone.0186632. eCollection 2017.

- Pohanka V, Pohanka M, Fleischer P, Bičárová S. The role of the climate in complex treatment of respiratory disease. Zdrowie Publiczne i Zarządzanie. 2012; 10 (1): 9-12 doi: 10.4467/20842627OZ.12.002.0889 


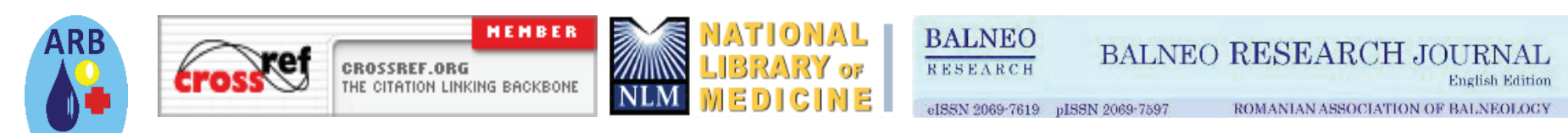

\title{
L67 - Biological insights of Speleotherapy
}

\author{
Constantin MUNTEANU ${ }^{1,2}$, Diana MUNTEANU ${ }^{3}$, Mihail HOTETEU ${ }^{4}$
}

Corresponding author: Constantin MUNTEANU, E-mail: office@bioclima.ro,

1. Romanian Association of Balneology, Bucharest, Romania

2. Emergency Clinical Hospital Bagdasar-Arseni, Bucharest, Romania

3. National Institute of Rehabilitation, Physical Medicine and Balneoclimatology, Bucharest, Romania

\begin{abstract}
4. Biosafety LTD, Bucharest, Romania

Introduction. Speleotherapy uses the microclimate of salines and caves, with certain properties, to treat many respiratory or dermatological conditions (eg burns and injuries). The presence of numerous saline and caves in our country represents a significant strategic advantage in the development of spa tourism.

In general, balneotherapy is practiced in a specific natural setting, characterized by the absence of pollutants. Material and method. 16 Articles published in Balneo Research Journal, having as main subjects speleotherapy and haloaerosolotherapy were analized in order to have an image of the relevance of this domain in Balneology during the last 10 years of existence of the Journal.
\end{abstract}

Results and discussions. Articles titles are as follow:

- Exploration of the speleotherapeutic potential through the cellular and molecular biology techniques (1)

- Study of underground medium and medical- biological experimental in Turda Salt Mine (2)

- The experimental effect of artificial air ionizer (negative and positive) on some hematological parameters at Wistar rats (3)

- The experimental effect of artificial air ionizer on some nonspecific resistance parameters and immune system at Wistar rats (4)

- Speleotherapy development In Romania on the world context and perspectives for use of some salt mines and karst caves for speleotherapeutic and balneoclimatic tourism purposes (5)

- Existing and perspective arrangements to Salina Cacica in the context of tourism development in salt mines (6)

- Speleotherapy effects on Wistar rats reflected by pulmonary and dermal fibroblasts cultures (7)

- Morphological and electrophoretic data about heterogeneous primary skin cells cultures obtained from normal and Ovalbumin-Challenged Wistar rats after treatment by speleotherapy in the Cacica and Dej Romanian Salt Mines (8)

- Morphological and electrophoretic data of primary pulmonary fibroblasts cultures obtained from normal and Ovalbumin-Challenged"Asthmatic" Wistar rats treated by speleotherapy in Cacica and Dej Romanian Salt Mines (9)

- Therapeutical evaluation of Turda Salt Mine microclimate on pulmonary fibroblasts cultures (10)

- In vitro experimental evaluation of wound and burns healing capacity after exposure to salty microclimate from Dej and Cacica (11)

- Speleotherapy - scientific relevance in the last five years (2013 - 2017) - A systematic review (12)

- The usage of Haloaerosolotherapy in the Rehabilitation treatment of children with reccurent bronchitis (13)

- New technologies of haloaerosoltherapy at asthmatic patients (14)

- Which salt mine do you recommend for Speleotherapy? Interdisciplinary project proposal (15)

- The role of haloaerosolotherapy in immunorehabilitation of convalescents after community acquired pneumonia (16)

Conclusion. Speleotherapy is well covered as a subject in Balneo Research Journal, 16 of 250 articles means about $6,4 \%$ of total articles, reflecting the importance of this sub-domain.

Key words: Speleotherapy, Haloaerosolotherapy, Balneo Research Journal, 


\title{
L68 - Aerosols and Breathing
}

Paraschiva POSTOLACHE ${ }^{1}$, Cristina LACATUSI ${ }^{2}$, Doina-Clementina COJOCARU ${ }^{3}$

Corresponding author: Paraschiva Postolache, E-mail: postpar04@yahoo.com

1,2. "Grigore T. Popa" University of Medicine and Pharmacy, Iasi, Romania

1,2. Clinical Rehabilitation Hospital - Pulmonary Rehabilitation Clinic, Iasi, Romania

\begin{abstract}
We breathe as soon as we are born and until we die. It is a constant and vital need not only for us but for all forms of life on Earth. Poor air quality affects us all: it is detrimental to our health and to the environment, and this leads to economic losses. Aerosols are fine particles of liquid or solid substance combined with a gaseous medium (natural air or compressed air) and inhaled into the lungs. Therefore, the aerosols may be natural: marine (in the area of the dams, where the waves break), forest (by combining a volatile substance with pollen in the air) or saline, and artificial (generated by special devices called nebulizers). Aerosol or nebulizer therapy is very common. The nebulizer is the one that has beneficial effects in asthma, COPD or bronchiectasis, etc. It creates small particles (less than 4 microns in diameter), particles that due to these dimensions reach the smallest pulmonary branches. Therefore, in moderate and severe exacerbations, it is recommended to administer medicines using the nebulizer. The aerosol dispenser creates larger particles and is used in upper airways disorders: respiratory viruses, flu or other ORL disorders. Aerosol medication is useful in these situations because it acts locally and the effect is faster.
\end{abstract}

Key words: aerosols, pulmonary and ORL diseases.

\section{References:}

Khilnani GC, Banga A. Aerosol therapy. Indian J of Chest Dis \& Allied Sci. 2008; 50: 209-220. http://medind.nic.in/iae/t08/i2/iaet08i2p209.pdf

Dhanani J, Fraser JF, Chan HK et al. Fundamentals of aerosol therapy in critical care. Critical Care. 2016; 20 : 269 https://doi.org/10.1186/s13054-016-1448-5 


\title{
L69 - Respiratory Muscle Training and Respiratory Rehabilitation
}

Paraschiva POSTOLACHE ${ }^{1}$, Madalina ZEBEGA ${ }^{2}$

Corresponding author: Paraschiva Postolache, E-mail: postpar04@yahoo.com

1,2. "Grigore T. Popa" University of Medicine and Pharmacy, Iasi, Romania

1,2. Clinical Rehabilitation Hospital - Pulmonary Rehabilitation Clinic, Iasi, Romania

\begin{abstract}
Introduction. Respiratory muscles (inspiratory and expiratory) are essential in maintaining the normal ventilation and proper gas exchange. Any imbalance in their function causing clinical symptoms such as: exercise intolerance, dyspnea, hypercapnia, ineffective cough.

Material and methods. Respiratory Muscle Training (RMT) is a specific method, part of the pulmonary rehabilitation program of the chronic respiratory diseases that have respiratory muscle weakness. Along with general physical training, RMT can be included in the multidisciplinary pulmonary rehabilitation program that improves the physical, psychological and social performance of patients with chronic respiratory disease. Pulmonary rehabilitation programs include physical exercise as a key component alongside assessment, education, psychological support and nutritional counseling. This training of the respiratory muscles begins in specialized rehabilitation centers, where it is performed according to protocols and under strict medical supervision and continues long-term at home, at least 30 minutes a day.

Results. The muscle training improves muscle strength, endurance time, 6 or 12 minute walk distance, reduces dyspnea (Borg and mMRC dyspnea scale) and improves the quality of life (COPD Assessment Test - CAT). Conclusions. Respiratory muscular training offers significant benefits such as improving muscle strength and endurance, increasing exercise capacity, reducing dyspnea and improving the quality of life in chronic respiratory patients.
\end{abstract}

Key words: respiratory muscles, training, pulmonary rehabilitation, outcome.

\section{References:}

1. Charususin N, Gosselink R, Decramer M et al. Inspiratory muscle training protocol for patients with chronic obstructive pulmonary disease (IMTCO study): a multicentre randomised controlled trial. BMJ Open. 2013; 3: e003101. doi:10.1136/bmjopen-2013-003101

2. Celli BR, Stoller JK, Hollingsworth H. Respiratory muscle training and resting in COPD. C2019 April 18 UpToDate; https://www.uptodate.com/contents/respiratory-muscle-training-and-resting-in-copd

3. Illi SK, Held U, Frank I, Spengler CM. Effect of respiratory muscle training on exercise performance in healthy individuals: a systematic review and meta-analysis. Sports Med. 2012 Aug 1; 42(8):707-24. doi: 10.2165/11631670-000000000-00000. 
L70 - Developments and Involutions of Tourism in the Spa Resorts in Romania and the Case Study for Lacul Sărat Resort

\author{
Cristi FRENȚ ${ }^{1}$, Georgeta MAIORESCU ${ }^{1}$
}

Corresponding author: Georgeta Maiorescu, E-mail: maiorescu@incdt.ro

\title{
Abstract
}

1. National Institute of Research Development in Tourism, Bucharest, Romania

\section{Introduction.}

Spa tourism is one of the oldest types of tourism existent on the territory of Romania, and the diseases treated in spa resorts or in localities with natural therapeutic factors are among the most varied ones, based on the diversity of the mineral resource. The spa tourism also has a strong socio-economic impact acting as an engine to stimulate the economic development mainly at regional and local level by combining the spa cure with different recreational or cultural activities. In these circumstances, the demand for spa tourism in Romania registered both strong development periods such as from '70s to '90s and significant involutions which were quantified by the evolution of tourist flows.

\section{Material and method.}

Using existing data published by the National Institute of Statistics the aim is to present the developments/involutions of tourism in spa resorts in Romania. In this regard a distinction will be made between inbound tourism (foreign tourists accommodated in spa resorts), domestic tourism (Romanian tourists accommodated in spa resorts), accommodation capacity and its usage. The following indicators are analyzed: number of arrivals (number of tourists), number of overnight stays, average length of stay, number of bedplaces, and occupancy rate for bed-places. Also, a comparison is made between the evolution of tourism in spa resorts compared with the general tourism evolution in Romania in the last 25 years.

Nevertheless, for Lacul Sărat resort a similar analysis cannot be undertaken due to lack of data before 2017 (the available statistics are published only starting 2017 for Chișcani locality, the locality to which it belongs now as before Lacul Sărat was part of Brăila municipality). Instead some estimates were included for the period 2013-2016 taken from a study performed by INCDT in February 2018.

\section{Results and discussions.}

The last 25 years are shaped by a constant decline of the existing accommodation capacity in spa resorts, in 2018 this capacity representing only $10.2 \%$ of Romania's accommodation capacity (compared with $16.1 \%$ in 1993). In average, tourists spent less nights in spa resorts which is certified by the decline in the length of stay from 6 days in 1993 to just over 4 days in 2018.

The doubling of the number of overnight stays of foreign tourists at national level in the last 25 years is in total contradiction with the decrease of the same indicator registered in spa resorts, in 2018 being approximately $45 \%$ less overnight stays of foreign tourists in spa resorts compared with the reference year 1993. The same declining trend is seen for Romanian tourists in spa resorts $(-18.7 \%)$. Nevertheless, the accommodation units located in spa resorts report occupancy rates that were superior to the national average in 2018 (44.8\% compared with $32.2 \%)$.

For Lacul Sărat resort the statistical data for belonging locality Chișcani shows the existence of a number of almost 20 thousands tourists in 2018, an average length of stay of almost 7 days and an occupancy rate of $53.7 \%$, the latter being superior to the level registered in general by spa resorts (44.8\%).

\section{Conclusions.}

The spa resorts do not have a negligible share in the total overnight stays of Romanian tourists registered at national level (less than $20 \%$ in recent years). This undoubtedly shows the importance of this type of tourism for Romania. Also, Lacul Sărat which is in the progress to be certified as "balneoclimatic resort" can regain its notoriety through a balanced and harmonious development based on the principles of sustainable development.

Key words: tourism, statistics, spa resorts, Romania, Lacul Sărat 
L71 - Mathematical model of sulphur absorption process, a possible application in cure with sulphurous mineral water

\author{
Dragos Arotaritei ${ }^{1}$, Andrei Gheorghita ${ }^{2}$, Mariana Rotariu ${ }^{3}$, Marius Turnea ${ }^{4}$
}

Corresponding author: Mariana Rotariu, E-mail: rotariu29@yahoo.com

\begin{abstract}
Introduction: The content of sulphur in human body is about .25 percent of total body weight. The research for modern therapies include the usage of sulphurous spring waters as therapeutic and preventive treatment large category of diseases. High levels of hydrogen sulphide are extremely toxic and as result the model of absorption of sulphur could be useful as predictor in a daily treatment during a cure with sulphurous mineral water.

Materials and methods: The quantity of chemical elements from a specific diet rich in these elements absorbed in human organism is one of the most important characteristic of a benefic cure in medical diseases. The most studied mechanisms of absorption were studied for zinc, magnesium, iron and calcium. The most common way to develop a mathematical model is to use the pharmacokinetic equations based on MichaelisMenten approach (first order model) and to develop it thereafter for quantitative relations. In some cases only experimental data can exists and the pharmacokinetic model is not completely elucidated or a simplified model doesn't exist yet. A model based on genetic programming is proposed in order to discover a mathematical formula between dietary sulphate (mmol/day) and total sulphate in ileostomy fluid (mmol/day) using experimental data published in literature.

Results: The set of terminal used in genetic programing is reduced to basic operation (sum, difference, multiplication and division) along with the most plausible operations that could have physical meaning: rooted square, exponential and power on an integer number. The experimental results showed a good fit of data with the mathematical formula, the rooted mean square error below $1.5 \%$

Conclusions: Alternative to pharmacokinetic, mathematical formulas discovered by genetic programming can be used to predict sulphate and sulphite absorption and excretion. A correlation with pharmacokinetic equations in the case that these exist will help the improvement of terminals and alphabet used by genetic programming in order to close the result to a physical meaning.
\end{abstract}

Key words: sulphur absorption, sulphurous mineral water, mathematical model, genetic programming 


\title{
L72 - The efficiency of the Rehabilitation Service in hospital conditions
}

\author{
Mihai Ciocanu, Anișoara Cimil
}

Department of Social Medicine and Management USMF ”Nicolae Testemițanu,, Moldova Republic.

\begin{abstract}
Introduction: Quality management is a prerequisite for the harmonization of the current functioning of health care systems, including the purpose of the hospital as a provider of efficient and quality medical services in optimum conditions for as many patients as possible.

The optimal use of resources is to be tailored to identified needs to meet the complexity of health requirements, defines congruent objectives in achieving its work. The purpose of implementing this type of management is to improve the quality of medical services, meet the expected needs and optimize the relationship between the healthcare provider and the beneficiaries.

Materials and Methods: The research methodology included the analysis of hospital unit operation processes from the beneficiary's perspective and the need for development tailored to the needs of patients requiring recovery at the Institute of Urgent Medicine and Clinical Hospital of Traumatology and Orthopedics (Republic of Moldova) during the years 2018-2019. The performance of the respective hospitals has been phased out, assessing the quality of provision of the complexity of medical services: ensuring the modern conditions of the infrastructure in accordance with the need of the beneficiaries in medical services, optimized in terms of professional performances, as well as the analysis of the medical-economic performance indicators.

Results: Quality management performance indicators have been monitored by ensuring continuous improvement of the quality of the medical act, focusing on the diversification of the medical services offered to the beneficiaries and the quantification of the likelihood of occurrence of the risks and the severity of the unwanted effect.

Assessment of performance indicators was carried out compared to national averages and the indicators of the perpetual, monthly, quarterly and annual years, as benchmark in the monitoring process and the medicaleconomic indicators.

Conclusions. The efficiency of the Rehabilitation Service in hospital conditions was quantified according to 3 performance indicators: the coefficient of medical effectiveness summarized by $0,76-0,74$ of 1 unit; medical efficacy indexes $0,8-0,92$ of 1 unit; the coefficient of the curative (medical) results summarized by 0,96-0,98 of 1 unit.
\end{abstract}

Key words: Quality Rehabilitation Service, management, performance indicators.

1. Stineman M.G. Case-mix measurement in medical rehabilitation. Arch Phys Med. Rehabil. 1995 Dec; 76 (12):1163-70. 
L73 - Trial on the water consumption by the persons in the group aged 19-30 years

\author{
Sinziana Calina SILISTTEANU1 ${ }^{1}$, Andrei Emanuel SILISTTEANU²
}

Coresponding author: Sinziana Silisteanu, E-mail: sinzi silisteanu@yahoo.com

${ }^{1}$ Railway Hospital Iasi - Specialty Ambulatory of Suceava - "Stefan cel Mare" University of Suceava, Romania

${ }^{2}$ Cluj School of Public Health - FSPAC - Babeș-Bolyai University, Romania

\begin{abstract}
Introduction. It is generally considered that water is essential for the man, enabling the purification of the body, the toxin elimination and the good operation of the internal organs. Water is useful for the increase in the quality of the muscles and joints but also for the better development of the cognition, especially in the growth period, covering the brains' necessities. Water is used in diets but also for making food. It is known that water represents approximately $75 \%$ from the body weight of a baby, about $60 \%$ from an adult's and respectively $50 \%$ from an old person's. That is why water is found over $80 \%$ in the blood and in the muscles, about $60-70 \%$ in the skin and hair, and $20 \%$ in bones.
\end{abstract}

The objective of the trial was to assess the water consumption by the youth and the type of water consumed as well as to analyse its quality.

Material and methods. It was the analysis of the data obtained from 195 subjects who filled in a questionnaire about the water consumption. The questionnaire had 30 questions among which the ones related to the type of water consumed, the daily quantity and the consequences of the water consumption.

The results obtained show that people drink water from the tap, from the well, but also bottled water, especially still mineral water which enables hydration and toxin elimination, but which may also be drunk in large quantities. There are plenty of consumers of sparkling mineral water, especially in the hot periods of the year or after prolonged intense efforts.

Conclusions. The youth in this trial, aged 19-30, mainly drink still mineral water, especially after a kinetic therapy program in the gym or after a prolonged physical effort. However, there is a percentage of young persons who drink only sparkling mineral water or only tap water. Having in view that in 4-5 weeks, about 6 $\%$ of the human body totally changes, for the renewal of the water, it is necessary to drink on average 2-2.5 litres of water daily, according to the age, sex, physical activities and comorbidities that could provide with the adequate water balance.

Key words: still mineral water, sparkling mineral water, tap water, water balance 


\title{
L74 - Management of special arterial diseases
}

\author{
Liviu Lazăr, Florin Marcu, Felicia Cioară, Carmen Nistor Csepentö
}

\begin{abstract}

\section{Introduction}

Peripheral artery disease, also called Peripheral arterial disease, is a common circulatory problem in which narrowed arteries reduce blood flow to the limbs, causing the appearance of symtoms, most notably leg pain when walking (claudication).

Peripheral artery disease is also likely to be a sign of a more widespread accumulation of fatty deposits in arteries (atherosclerosis). This condition may be reducing blood flow to heart and brain, as well as legs.
\end{abstract}

\section{Material and methods}

Raynaud's syndrome, also known as Raynaud's phenomenon is a medical condition in which spasm of arteries cause episodes of reduced blood flow. Raynaud's disease is characterized by episodic attacks of pallor or cyanosis or pallor fallowed by cyanosis of the fingers and more rarely of the toes, caused by cold or emotional stress.

Systematic vasculitis is a heterogenous group of disorders charcterized by vessel wall inflammation. It causes changes in the blood vesel walls, including thickening, weakening, narrowing or scarring. These changes can restrict blood flow, resulting in organ and tissue damage and alteration of the circulation in the affected area. Thrombangiitis obliterans (TAO), an inflamatory vasculopathy, is a segmental disease of the arteries and veins of the extremity. The disease, also known as Buerger's disease, affects the small distal arteries first and then progresses proximally if smoking is continued. Cessation of smoking is an absolute necessity.

Temporal arteritis is a form of vasculitis. In temporal arteritis, also know as giant cell arteritis or Horton's arteritis, the ophthalmic artery and the temporal arteries (the blood vessels near the temples) which supply blood from the heart to the scalp, are inflamed and narrowed.

Vibration syndrome is a secondary form of Raynaud's syndrome, an industrial injury triggered by continuous use of vibrating hand-held machinary. It can produce paresthesias, dysesthesias of the hand, Raynaud's phenomenon and after several years of evolution, can cause frank digital artery acclusion.

\section{Results}

Thoracic outlet syndrome is a condition in which there is compression on the nerves, arteries, or veins in the passageway from the lower neck to the armpit. The appearauce of typical symptoms such as: pain, weakness, loss of muscle at the base of the thumb, swelling is suggestive of this syndrome. Physical therapy is the first line of treatment of this syndrome, exercises that strengthen and strech the shoulder muscles to open the thoracic outlet, improve the range of motion and posture.

\section{Conclusion}

It is necessary that the management of special arterial disease be comprehensive and include the best medical and surgical treatment. Managing hypertension and diabetes reduces morbidity and mortality and can obviate the need for invasive. 


\title{
L75 - Evolution of cardiovascular risk factors after more than 2 periodic hospitalizations in the Covasna Hospital for Cardiovascular Rehabilitation
}

\author{
Mihaela-Carmen SUCEVEANU ${ }^{1}$, Paul-Nicolae SUCEVEANU ${ }^{1}$
}

Corresponding author: Mihaela-Carmen SUCEVEANU, E-mail: sucevenum@yahoo.com

1. "Dr. Benedek Geza” Hospital for Cardiovascular Rehabilitation Covasna, Romania

\begin{abstract}
Background: Cardiovascular rehabilitation effects are more beneficial proportionally with the length of the rehabilitation programs. This means that patients with cardiovascular diseases should participate in out-patient or home-based rehabilitation sessions. Physical training can also transform from a therapeutic action in a patient lifestyle that would contribute to the diminishing of the patient's cardiovascular risk. In-patient rehabilitation has real advantages: the physical training safety, patient monitoring, high compliance to lifestyle change, physical training, cardio-protective medication administration for high-risk patients. The balneary resort can positively influence the cardiovascular risk reduction through the applied natural factors in repetition at 6-12 months.
\end{abstract}

Aim: In this context we wanted to analyze whether more successive hospitalizations in a rehabilitation hospital that is located in a balneary resort can influence the cardiovascular risk in cardiovascular patients.

Materials and methods: There were taken into account a number of 25 patients with the average age at the first admission of 63,40 \pm 7,27 years with limits between 53-77 years, 14 (56\%) women, 11 (44\% men) which were hospitalized 3 times periodically and consecutively in "Dr. Benedek Geza" Hospital for Cardiovascular Rehabilitation Covasna. Only 14 of these patients had a $4^{\text {th }}$ admission. All the patients were evaluated clinically, biologically and statistically. They were evaluated from different points of view such as main cardiovascular risk factors, preexistent cardiovascular diseases, medication and prescribed rehabilitation methods.

Results: There were no significant differences between the 3 admissions in terms of risk factors prevalence between the 2 genders. There were no differences regarding the cardiovascular risk factors depending on age. In terms of cardiovascular diseases, the only significant difference between the 2 genders (that was maintained in all admissions) was the arteriopathy, which was more frequent in males. There were no differences between the 2 genders concerning the rehabilitation procedures that the patients followed. The biochemical profile was analyzed during each admission. Total cholesterol recorded reductions in both genders, with statistical significance reached only in males. Triglycerides were significantly lowered in both genders. Glycemia was also lowered in both genders. An important decrease of LDL-cholesterol was recorded in males at their $3^{\text {rd }}$ admission.

Conclusions: In cardiovascular patients, an increase in adherence to long-term cardiovascular rehabilitation programs, an improvement of the cardiovascular risk factors profile can be obtained through in-patient programs repeated at certain time intervals. The Covasna balneary resort with its specific natural factors offers a special and powerful aid in reaching those goals. 


\title{
L76 - THE EFFICIENCY OF MEDICAL REHABILITATION TREATMENT IN \\ PATIENTS WITH HEMOPHILIA AFTER SURGICAL ORTHOPEDIC INTERVENTIONS - THE EXPERIENCE OF "CRISTIAN SERBAN" BUZIAS CENTER
}

\author{
Mihaela DUTESCU ${ }^{1}$, Adina TRAILA ${ }^{1}$, Margit SERBAN ${ }^{2}$, Emilia URSU $^{2}$, Dorina MIU $^{1}$, Ioana \\ MALITA $^{1}$, Bianca CIRESAN ${ }^{1}$
}

mihaela2212@yahoo.gr

\begin{abstract}
Introduction. Hemophilia is a hereditary X-linked coagulopathy characterized by a deficiency of FVIII (hemophilia A) or FIX (hemophilia B) that causes hemorrhage depending on the severity of the disease; in cases of severe forms, spontaneous hemorrhage may be life threatening. Localized severe bleeding takes place at the different sites such as articular (ankle, knee, elbow), muscular ( iliopsoas, thigh, forearm ) and mucous membranes ( gums, tongue, rhinorrhea, genitourinary tract). Almost all of the patients with hemophilia $(\mathrm{PwH})$ have a form of arthropathy, most often disabling and deforming, with important static, balance, gripping and walking disorders, marked pain and a significant reduction in quality of life.
\end{abstract}

Material and method. The study includes the patients with hemophilia $(\mathrm{PwH})$ from all over the country, patients taking part constantly and periodically at our rehabilitation programs, a number of them underwent surgical procedures. From January 2017 until July 2019 a number of 19 patients benefited from surgical therapy and postoperative rehabilitation treatment. The patients are between 6 and 65 years of age; 17 patients with hemophilia A, 1 patient with hemophilia B and 1 patient von Willebrand disease patients. The clinical examination includes goniometric measurements, the number of joints with hemarthrosis / arthropathy, number of target joints ( $>4$ joint bleeding in 6 months), HJHS (Hemophilia Joint Health Score), Functional Independence Score in Hemophilia ( FISH score ), Visual Analogue Scale (VAS). The patients took part at a complex medical rehabilitation program, under the substitution therapy coordinated by the hematologist, a program consisting of individual kinesiotherapy, hydrotherapy, hydrokinesiotherapy, electrotherapy and massage, the duration of the treatment is between 20 and 40 days. The medical rehabilitation treatment has been associated with psychological counseling sessions and medical education lessons.

Results. Following the recovery program, we found a significant improvement in pain relief, increased joint mobility and improved quality of life. We also evaluated musculoskeletal status in these patients, suggesting both the severity and gravity of musculoskeletal impairment and the degree of disability.

Conclusion. Hemophiliac arthropathy is a severe form of joint disease, in most cases invalidating, which significantly reduces the quality of life of these patients. It is important to emphasize the vital role of rehabilitation treatment that $\mathrm{PwH}$ should follow, treatment that relieves pain, improves musculoskeletal function, prepares the patient for future arthroplasty, or recovers the joint/limb function after arthroplasty. Rehabilitation in hemophilia begins with diagnosis and continues throughout life, constantly and sustained, coordinated by a multidisciplinary team composed of a hematologist, rehabilitation physician, physical therapist, masseur and psychologist. 


\title{
L77 - PRECURSORS OF BALENOLOGY EDUCATION IN ROMANIA
}

\section{Dorin-Gheorghe TRIFF, Simona POP}

Corresponding author: Dorin-Gheorghe TRIFF

\begin{abstract}

\section{Introduction}

Various authors from the three Romanian historical provinces, with particularities related to the different historical evolution of these provinces, have preceded and prepared through their studies, the emergence of balneology education in Romania

Materials and Methods: Literature survey

\section{Results}

The first papers from our country in the field of balneology described the mineral waters of Transylvania (I Matyus, M Neustadter, S Koleseri, L Wagner, S Hatvany, J von Greissig, A Kurz, L Kovary, F Nyulas, I Meyr), Moldova (L Steege, B. Hacquet, D Cantemir, D Apostolescu, V Butiureanu) or Wallachia (M Wertheimer).

Vasile Popp contributed to the development of Romanian medical terminology, being the author of the first medical paper in the field of balneology ("About mineral waters from Arpătac, Bodoc and Covasna") (1821). The first balneology study in Wallachia, ("The Metallic Waters of Great Romania, researched, described, and accompanied by a dietetic and macrovietic") was written by Ştefan Episcopescu (1857).

Other remarkable authors are: Anastasie Fătu (1874, "The description and use of communal water and mineral water in Romania, Moldavia and Muntenia") and Alexandru Şaabner-Tuturi (1900, "Mineral Waters and Climatic Resorts in Romania"). The first manual of hydrotherapy in Romanian was published by Gheorghe Baiulescu (1904)

Doctor Ion Hozan, head of the hydrotherapy department of Grafenberg spa resort, played a special role in decisively influencing Marius Sturza's career. The latter became tenured lecturer of the first Department of Balneology and Physiotherapy at the Faculty of Medicine in Cluj (1931). At about the same time, Gheorghe Baltaceanu became the head of the Balneophysiotherapy Department at the Faculty of Medicine in Bucharest (1935).

\section{Conclusions}

In parallel with European studies in the field of balneology, studies that paved the way to the emergence of balneology and physiotherapy education in our country were published in Transylvania and in the Romanian Principalities.
\end{abstract}

Key words: education, physiotherapy, balneology, precursors 
L78 - Antiallergic procedures most commonly used in physical recovery medicine and balneology

\title{
Eugenia Dumitrescu, Carmen Enescu
}

Coresponding author: Eugenia Dumitrescu, Email: jenydumitrescu2003@yahoo.com

\begin{abstract}

\section{Introduction}

Allergic diseases: cutaneous, respiratory or digestive disorders are common diseases of modern humans.

Multiple causes: Pollution, stress, unhealthy eating; sometimes the simple rules of healthy living are neglected.

The objective of the research

Confronting modern medicine with the "dead tradition"

\section{Material and methods}

Clinical tests were performed on 670 patients who came to the hospital especially for the reduction of allergic skin and respiratory phenomena between March 2018 - December 2018. More than 50\% of the decisions of the prophylaxis and recovery program were taken following medical analyzes and paraclinical investigations.
\end{abstract}

\section{Methods used:}

Intramuscular injection with sulfur water

Aerosol with sulfurous water

Sulfurous water in pools and baths

\section{Result and discussions}

500 patients had significant improvements in allergic skin and respiratory phenomena. They no longer used the medication.

102 patients continued to use the medication recommended by the allergist and dermatologist along with the bathing procedures.

68 patients, heavy smokers, did not follow diet recommendations, healthy lifestyle and did not have significant improvements

\section{Conclusions}

The antiallergic effect of sulfur is as real as possible and has been scientifically proven

Sulfur in combination with other classic recovery programs is important for reducing the intensity of allergic skin and respiratory phenomena

The sulfurous water from the baths and baths also helped in the case of osteo-articular disorders

The alternative remedy can be used in whole or in part instead of the conventional one

The quality of life of patients has been greatly improved 


\title{
L79 - Peloids - perspectives on research and future plans
}

\section{Constantin MUNTEANU ${ }^{1,2}$, Diana MUNTEANU ${ }^{1,3}$, Mihail HOTETEU ${ }^{1,4}$, Gabriela DOGARU ${ }^{1,5}$}

\author{
Corresponding author: Constantin MUNTEANU, E-mail: office $@$ bioclima.ro,
}

1. Romanian Association of Balneology, Bucharest, Romania

2. Emergency Clinical Hospital Bagdasar-Arseni, Bucharest, Romania

3. National Institute of Rehabilitation, Physical Medicine and Balneoclimatology, Bucharest, Romania

4. Biosafety LTD, Bucharest, Romania

Abstract

5. Iuliu Haţieaganu Medical and Pharmacy University, Cluj-Napoca, Romania

Introduction. Peloids (muds) used in peloidotherapy, one of the special treatments in the spa field are organic or inorganic substances formed as a result of geological and / or biological events. They are used in the form of mud baths and mud packs in various diseases.

Published articles in Balneo Research Journal on the subject of peloidoterapy are the following 5 articles:

- Bioactive substances of the Techirghiol therapeutic mud content (1)

- Artemia salina (2)

- Therapeutic muds (3)

- Estrogenic compounds -endocrine disruptors (4)

- Investigation of $\mathrm{pH}$ variation of blood during peloidotherapy (5)

The liquid phase of mud constitutes a hypertonic solution of minerals, organic humic substances, bituminous, carbohydrates, peptones, amino acids and enzymes. Since 1957 V.D. Narti proposed the utilization of natural solutions of this therapeutic mud, besides classical procedures with mud. The solution envisaged by Narti, "PELOIDEXTRACT", was extracted by filtration under pressure of 6-12 atmospheres of inert gas (CO2). The solution obtained from Techirghiol mud is a clear liquid, stable, with a density of 1.062 at $21^{\circ} \mathrm{C}$, with an alkaline $\mathrm{pH}$ of 7.6 to 8 , and mineral content closely comparable to that of blood serum, except SO42-and $\mathrm{Mg} 2$ + , which are in excess. The natural solution would be a hypertonic solution 10 times more concentrated than blood serum. For cellulite treatment extracted mud is mixed to form a cream with plant extracts and bioactive substances. In psoriasis, seborrheic and atopic dermatitis, eczema and first degree burns is used a cream containing 1-6\% suspension of mud as active ingredient. In addition, the mud suspension may be used to create dermal application dressings. The mud is composed of humic substances, pectin, cellulose and lignin, waxes, resins and inorganic materials, also including identified structures such as alkanes, 4-phenyl valeric acid, 5-

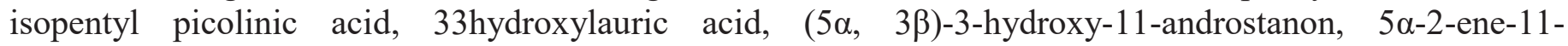
androstenone, squalene, $\alpha$ terpineol, menthol derivates, palmitic, oleic and eicosanoic acid and the isoprenoid phytan.

Material and method. All the above data about life extension, geroprotectors, peloid and plant components, antioxidants, diet elements and phytochemicals constitute the general scientific bacground from which the proposal goes on, looking to combine selected fractions of peloid and plants in new healthy ageing products and to test them on animals, cells and humans.

Results and discussions. Combining the best fractions of mud obtained will result in getting the mud extract that will be used to obtain the new healthy-ageing products by adding plant extracts in a xylitol matrix. Xylitol is a five carbon sugar alcohol that naturally occur in foods such as fibrous vegetables and fruit. It is a natural, intermediate product which regularly occurs in the glucose metabolism. Xylitol is produced naturally in our bodies; in fact, we make up to 15 grams daily during normal metabolism. Xylitol has $40 \%$ fewer calories than sugar.

Conclusions. Main scientific concepts with wich Balneology is operating, interdisciplinary connections and authors interests were focused ideas to have in mind by the authors of this article.

Key words: Balneology, Balneotherapy, Balneo Research Journal, Peloidotherapy, Balneary Resort 


\title{
L80 - THE SCIENCE OF AGING WELL
}

\section{Liliana Stanciu ${ }^{1}$, Daniela Profir ${ }^{1}$, Viorica Marin ${ }^{1}$, Doinița Oprea ${ }^{1,2}$, Elena Ionescu ${ }^{1,2}$, Elena Almășan ${ }^{1}$, Carmen Oprea ${ }^{1,2}$}

Corresponding author: Liliana Stanciu, E- mail: lilianastanciu77@yahoo.com

\begin{abstract}
Introduction: Romania will record an accelerated rhythm of aging among its population in the coming decades. It is very important to increase life expectancy through medical advances and by improving the quality of life. Lately, the studies in this field have been focusing on epigenetics and the discovery of new macromolecules with an important role in aging.

Material and method: Researching the standard medical data bases - Medline, Embase, Database, PubMed and the registry of Cochrane controlled trials - in order to review the literature data on new macromolecules with impact on the growth of life expectancy and on molecules with a well-known role.

Results and discussions: A number of relevant studies have identified the role of certain molecules on the increase of life span by having an impact on the muscular system, osteoarticular system , bone metabolism and neuronal activity: irisin (adipo-myokines), sirtuins, FGF-23 and Klotho protein, vitamin D, estrogens.

Conclusions: Researches in the anti-aging field are constantly developing, and the recent discovered molecules have important actions on certain pathophysiological links, which are also influenced by the balneary treatment performed in the Balneal and Rehabilitation Sanatorium Techirghiol. Subsequent studies on the sapropelic mud in terms of influencing the above-mentioned macromolecules are absolutely necessary in order to strengthen the role of this natural treatment in the physiological process of aging.
\end{abstract}

Key words: mud, aging, epigenetics, hormones, 
L81 - Influence of nutrition and exercise on the use of different energy substrates in the prevention of metabolic diseases

\title{
Simona Carniciu
}

Center for Research, Diagnosis and Treatment in Diabetes and Metabolic Diseases CORPOSANA, Bucharest, Romania

\begin{abstract}
The lifestyle has been increasingly studied in recent decades, due to the huge impact on the health of the population and the increase of the risk of chronic diseases. Obesity, sedentary lifestyle is closely linked to the appearance and evolution of diseases such as cardiovascular disease, metabolic syndrome, diabetes or cancer. The disposition of adiposity, genetically determined, influences the cardiovascular risk and is a modifiable target factor through lifestyle changes. Several studies on the consumption of different energy substrates and their effects on weight and metabolism were analysed. Physical exercises combined with a proper diet can influence weight loss. The individualization of the diet and exercise program is necessary because it influences the use of different substrates. Thus, the movement focused on lipid oxidation reduces the appetite and the caloric intake, at the opposite pole being intense exercises that dissipate carbohydrates, being orexigenic and can lead to weight gain. Although the mechanisms of LIPOXmax are not completely elucidated, epigenetic reprogramming of metabolism is suspected. LIPOXmax exercises have shown long-term benefit in weight loss, including in bariatric post-surgery patients. The effects are stable, long-lasting and have important effects on metabolism, increasing mitochondrial activity, improving blood glucose and lipid levels, or body composition.
\end{abstract}


P1 - Proprioceptive Functional Vibration Stimulation as therapeutic tool in spasticity management of jump gait pattern of spastic diplegic children with cerebral palsy

Andra Pintilie $^{1}$, Liliana Pădure ${ }^{1,2}$, Andrada Mirea ${ }^{1,2}$, Corina Sporea $^{1,2}$

Corresponding author: Andra Pintilie, E-mail: andra.pintilie@gmail.com

${ }^{1}$ The National Teaching Centre for Neuro-psycho-motor Rehabilitation in Children "Dr. Nicolae Robănescu",

2.The University of Medicine and Pharmacy "Carol Davila", Bucharest, Romania

\begin{abstract}

\section{Introduction}

Cerebral palsy, a neurological disorder determined by a multitude of conditions (congenital, $\mathrm{pre} /$ natal/postnatal causes), with a prevalence of 2-2.5/1000 births, is characterized by motor and function loss, with the most frequent motor element represented by spasticity, and last but not least, by hypotonia, and secondary gait impairment.

The purpose of our work is to follow up and assess the effects of proprioceptive functional vibratory stimulation (PFVS) on the jump gait pattern of spastic diplegic gait in children with cerebral palsy. The child with jump gait has equinus foot, genu flexum and coxa flecta, related to spasticity on the gastrocnemian and soleus, hamstrings and psoas muscles. At first, the treatment is conservative and consists of muscular stretching, anti-spastic and anti-algic electrotherapy, thermotherapy, orthesis wearing.

In order to obtain spasticity decrement on the main muscle groups involved in jump gait and improve motor control, we advance the proprioceptive functional vibratory stimulation procedure.

\section{Materials and methods}

Functional vibratory stimuli were applied using a mobile unit commercial medical device for bedridden and standing patients, on the lower limb antagonist muscles, associated with physical therapy, once a day for two weeks, in a group of 10 children with jump gait and cerebral palsy. Ashworth Modified Scale and 10 meters test were used as evaluation tools for spasticity intensity and establishing improvement or decrement of gait pattern.
\end{abstract}

\title{
Results
}

Though still undergoing observation, the few results obtained so far show a moderate amendment in gait pattern, with slightly softening of the targeted muscles.

\section{Conclusions}

Regarding the short amount of time since the observation started, we are inclined to believe that the continuation of the program using proprioceptive functional stimulation and physical therapy, will lead to better results with considerate attenuation of jump gait pattern.

Key words: proprioceptive functional vibration stimulation, jump gait, spastic diplegia, cerebral palsy 

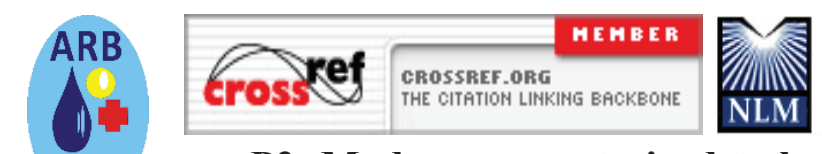

P2 -Modern computerized techniques for gait's functional evaluation through a specialized wireless inertial sensor - premise for orthopedic corrective shoes wear in children with gait

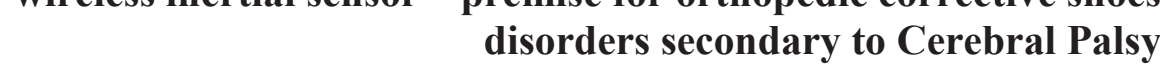

Andra Pintilie ${ }^{1}$, Liliana Pădure ${ }^{1,2}$, Andrada Mirea ${ }^{1,2}$, Corina Sporea ${ }^{1,2}$

Corresponding author: Corina Sporea, E-mail: corina.sporea@gmail.com

${ }^{1}$ The National Teaching Centre for Neuro-psycho-motor Rehabilitation in Children "Dr. Nicolae Robănescu”,

2.The University of Medicine and Pharmacy "Carol Davila", Bucharest, Romania

\begin{abstract}
Introduction

Cerebral palsy (CP) is defined as a neurological disorder, consequence of several congenital or pre/during/post natal causes that injure the immature brain. From the anatomy point of view and from motor deficit's perspective, CP classifies in: hemiplegia, paraplegia, tetraplegia, triplegia, monoplegia, with secondary gait impairment of different intensity.

The aim of our study was to evaluate and assess the gait cycle in hemiplegic children with CP, with and without orthopedic corrective shoes.

\section{Materials and methods}

The gait cycle was evaluated with a wearable system based on a specialized wireless inertial sensor attached to the patient.

We included a group of 36 children which wore corrective shoes on a daily base, for gait attenuation and postural control. The children were evaluated in two times, with and without wearing the specific shoes, and the following parameters were assessed: \% stride length, gait cycle duration, step length, stance phase duration, double and single support duration.

\section{Results}

Evaluation showed significant improvement in the assessed parameters when wearing the orthopedic corrective shoes, highlighted in gait symmetry. Also, gait's specific parameters approached the physiological values.

\section{Conclusions}

Following the obtained improved functional parameters, every evaluated child was furthermore encouraged to wear the corrective orthopedic shoes. Also, for every admitted pediatric patient with gait disorders secondary to motor impairment linked to Cerebral Palsy, we sustain the gait evaluation, through every approachable method and wearing the specific shoes.
\end{abstract}

Key words: gait disorders, cerebral palsy, gait assessment, functional parameters 
P3 - The role of medical recovery in oncology

\title{
Ana Maria PÂSLARU ${ }^{1}$, Ana Maria FĂTU ${ }^{1}$, Anamaria CIUBARĂ ${ }^{2}$
}

Corresponding author: Ana Maria Fătu, E-mail: anafatu09@gmail.com

1. PhD student at University "Dunarea de Jos", Galaţi, Romania. 2 PhD, Department of Psychiatry, Faculty of Medicine and Pharmacy, "Dunarea de Jos University", Galați, România.

\begin{abstract}
Introduction.

The therapeutic advances have increased the survival of oncology patients. The management of neoplastic disease undergoes an important period of change, from the approach centered on tumor eradication to entirety patient's care. At this time, the multidisciplinary approach of the patient is extremely important for the success of the treatment.

\section{Materials and methods.}

Analyzing studies that examine the role of medical recovery programs among oncological patients demonstrates the need to introduce them into the treatment plan. Multiple research has highlighted the benefits of physical activity in preventing medical conditions. However, another approach is now being attempted, exercise as a remedy for neoplastic disease. The results of a study presented at the Australian Prostate Cancer Conference in 2011 showed that performing resistance and impact exercises had an effect in stopping bone loss in patients in anti-androgen therapy. Some research suggests that oncological patients, which are included in medical recovery programs, aiming at maintaining an adequate body weight, using a physical exercise program tailored to individual effort tolerance and nutritional compliance, show better compliance with antineoplastic treatment with fewer side effects.
\end{abstract}

\section{Results and discussions..}

The alarming increase of the number of patients diagnosed with cancer tends to place this condition as the leading cause of morbidity and mortality in the world and thus to dethrone cardiovascular disease. The multitude of investigations and treatments to which the oncologist is subjected from the time of diagnosis to the completion of treatment, have a significant impact on their physical and mental integrity. Specialist literature recommends integrating patients into a medical recovery program to maintain psychosocial integrity, adherence to treatment, and preserve their quality of life.

\section{Conclusions}

The purpose of this paper is to emphasize the importance of physical exercise ,both in the prevention and treatment of certain medical conditions. Personalized medical recovery programs are indispensable in the current management of the oncology patient.

Key words: Physical exercise, oncological patient, cancer 
P4 - Exercises availed by sensor-based computer advanced devices: part of the interactive cognitive recovery - adjuvant of the therapy applied in the "Dr. Nicolae Robanescu" National Clinic Centre for Neuropsychomotor Rehabilitation in Children

Maria Veronica MORCOV ${ }^{1}$, Liliana PADURE ${ }^{1,2}$, Cristian Gabriel MORCOV ${ }^{1 *}$, Gelu ONOSE MN $^{2,3}$

Corresponding author: Cristian Gabriel MORCOV, morcov.cristian@recuperarecopii.ro

urnal DOI: http://dx.doi.org/10.12680/balne0.2019.276 Poster Vol.10, No.3, September 2019 p: 408

1“Dr. Nicolae Robanescu” National Clinic Centre for Neuropsychomotor Rehabilitation in Children, 2 "Carol Davila" University of Medicine and Pharmacy, Bucharest, Romania

${ }^{3}$ Teaching Emergency Hospital "Bagdasar-Arseni”, Bucharest, Romania

Abstract

Introduction. Sensor-based computer facilitating serious gaming is a modern approach of the NeuroRehabilitation as an additional intervention to the traditional therapy [1]. Especially used to improve motor skills [2], robotics (as the term is often largely extended to the type of above mentioned treatment endeavors) can also be effective in cognitive rehabilitation therapy by training domains as thinking, memory, attention, and language.

Robotic recovery can cover a wide range of pathologies, from cerebral palsy - "lesions of developing central nervous system, in which motor deficiency occurs before, during or soon after birth" [3] - to traumatic brain injury - "insult to the brain from an external mechanical force" [4].

Materials and Method. In the "Dr. Nicolae Robanescu" National Clinic Centre for Neuropsychomotor Rehabilitation in Children, within the Department of Therapeutic Education - 3 psychologists have been using a robotic device since 2017 to stimulate: focused and distributive attention, development or improving of graphomotor skills, training of executive functions and visual-spatial abilities, problem solving, hand-eye coordination, speech and language practice.

Results. Complementary to physically exercises, robotic therapy in cognitive recovery provides "interaction and social or interpersonal relationships", facilitates "play" and "communication" [5], allowing for immediate feedback and rewards, increases motivation and involvement of the patient.

Conclusions. Cognitive training mediated through "computing technology" [6] can be considered "a promising modern tool in therapeutic and educational interventions" [5] in children with congenital or acquired brain disorders.

It is still also a research challenge for psychologists who, using standardized specific evaluation instruments and data processing methods, before and after such kind of interventions, will be able to further objectify their potential effectiveness.

Keywords: serious gaming, sensor-based computer, cognitive rehabilitation.

\section{References:}

1. Hidler J, Sainburg R. Role of Robotics in Neurorehabilitation. Top Spinal Cord Inj Rehabil. 2011;17(1):42-49. doi:10.1310/sci1701-42

2. Bayon C, Raya R, Sergio LL, et al. Robotic Therapies for Children with Cerebral Palsy: a Systematic Review. Transl Biomed. 2016, 7:1. DOI: 10.21767/2172-0479.100044

3. Onose G, Pădure L. Compendiu de neuroreabilitare la adulți, copii și vârstnici. București: Editura Universitară "Carol Davila", 2008

4. Dawodu ST. Traumatic Brain Injury (TBI) - Definition, Epidemiology, Pathophysiology. Overview (https://emedicine.medscape.com/article/326510-overview)

5. Huijnen CAGJ, Lexis MAS, de Witte LP (2017) Robots as New Tools in Therapy and Education for Children with Autism. Int J Neurorehabilitation 4:278. doi:10.4172/2376-0281.1000278

6. Ma M, Zheng H. Virtual Reality and Serious Games in Healthcare. In: S. Brahnam \& L.C. Jain (Eds.): Adv. Comput. Intell. Paradigms in Healthcare 6, SCI 337, pp. 169-192.

(http://health21 initiative.org/wp-content/uploads/2017/08/2011-VR-and-Games-in-Healthcare.pdf) 
P5 - Theoretical fundamentals and conceptual premise for advanced proprioceptive and sensory stimulus apparatus, with sequential evaluation for the treatment of the recuperator in the equilibrium disorder, from Cerebral Palsy (PC) casuistry.

\author{
Avram $\mathbf{M}^{1,2}$, Liliana $\mathbf{P}^{1,2}$, Onose $\mathbf{G}^{1,3 *}$
}

Corresponding author: Cristian Gabriel MORCOV, morcov.cristian@recuperarecopii.ro

1. University of Medicine and Pharmacy "Carol Davila", Bucharest, Romania 2. National Teaching Centre for Children Neuro-psycho-motor Rehabilitation "Dr. N. Robanescu", Bucharest, Romania

\title{
Abstract
}

3. Teaching Emergency Hospital "Bagdasar-Arseni”, Bucharest, Romania

Introduction. The technological advances of the last decades, especially in this millennium, have allowed and stimulated the use of advanced devices and related modalities for therapeutic-recovery purposes; Among these, some mechatronic and / or, respectively, augmented / virtual reality generators, are among the most modern.

Materials and methods. In order to accomplish a documentation corresponding to the objective stipulated in the title, we have produced a systematic journal of the profile literature, according to the standardized methodology used and accepted internationally: "PRISMA", "Preferred Reporting Items for Systematic Reviews and Meta-Analyzes".

To this end, we interviewed five prestigious international databases of medical data: Elsevier, NCBI / PubMed, NCBI / PMC, Cochrane, PEDro using the well-known ISI Web of Knowledge / Science database to verify that articles identified by the word set - keywords / keyword combinations, and then searched for the bibliographic resources of this systematic journal, have been published in magazines indexed in this database. The keywords / keyword combinations I used were: "Virtual reality" and "cerebral palsy" and "adolescence" and "dose"; "Augmented reality" and "cerebral palsy" and "adolescence" and "dose"; "Immersive virtual reality" and "cerebral palsy" and "adolescence" and "dose"; "Virtual reality" and "cerebral palsy" and "adolscents" and "dose"; "Augmented reality" and "cerebral palsy" and "adolescents" and "dose"; Immersive virtual reality" and "cerebral palsy" and "adolescents" and "dose".

The search has gone through four stages, according to the PRISMA flow chart, adapted but without the final stage of meta-analysis. At the same time, to cover a volume of related bibliographic resources, as consistently as possible, we used extracted information and articles identified or discovered "freely".

Results. Using the methodology for making the above-mentioned systematic journal, we identified nine articles - which met all the search and filtering / selection criteria I had in mind - all in the NCBI / PMC and published between 2011-2018.

On the whole, we could synthetically substantiate the main defining and taxonomic elements related to the therapeutical and rehabilitation of the virtual reality $(\mathrm{RV})$ and its synergic association with proprioceptive stimulation modes by means of performing (re) equilibrium function - with sequential sequential evaluation facilities.

Conclusions. A key methodological element - which requires additional clinical research approaches - is to establish optimal dosing in combination algorithmic variants to optimize the expected outcomes, both in terms of effectiveness / effectiveness and safety.

Key words: systematic journal of literature, virtual reality, proprioceptive and sensory apparatus stimulation, related sequential assessment, equilibrium disorders, cerebral palsy.

\section{Selected reference:}

1.http://prisma-statement.org/documents/PRISMA\%202009\%20flow\%20diagram.pdf

2. https://www.elsevier.com/

3. https://www.ncbi.nlm.nih.gov (PubMed)

4. https://www.ncbi.nlm.nih.gov (PMC)

5. http://www.cochrane.org/; https://www.cochranelibrary.com/

6. http://search.pedro.org.au/search

7. https://apps.webofknowledge.com 
P6 - RESPIRATORY MANAGEMENT IN PATIENTS WITH

RARE PROGRESSIVE NEUROMUSCULAR DISEASES

\title{
Andrada MIREA ${ }^{1,2}$, Gelu ONOSE ${ }^{1,3}$, Madalina LEANCA ${ }^{2}$, Florin-Petru GRIGORAS ${ }^{2}$,
} Mihaela AXENTE ${ }^{2}$, Liliana PADURE ${ }^{1,2}$, Corina SPOREA ${ }^{1,2}$

Corresponding author: Cristian Gabriel MORCOV, morcov.cristian@recuperarecopii.ro

1. Universitatea de Medicina si Farmacie "Carol Davila", Bucharest, Romania 2. Centrul National Clinic de Recuperare Neuropsihomotorie Copii "Dr. Nicolae Robanescu" ,Bucharest, Romania 3. Spitalul Clinic de Urgenta "Bagdasar-Arseni”,Bucharest, Romania

\begin{abstract}
Introduction. It is well know that progressive neuromuscular diseases affects muscles from entire body, including the ones responsible for breathing. Spinal Muscular Atrophy (SMA) is among the most common rare disease in children that affect respiratory function.

Type I SMA is the most grave and lead to very weak intercostal muscles with a very soft and flexible chest during the first year of life, especially diaphragm, that is the primary muscle used to breath.

Due to the respiratory muscle hypotonia, the patients can't breath/ cough efficiently, thus not being able to eliminate the secretions that contribute supplementary to the respiratory insufficiency.

Materials and Methods. We studied the evolution of 8 patients with SMA type I, that received in different moments of their lives the correct management of respiratory tract. Some of them had very early non-invasive ventilation during sleep, others received it only after they suffered respiratory infections.

We observed the evolution of the chest perimeter during inspire every 4 months.

We measured the pulsoximetry, respiratory frequency and $\mathrm{CO} 2$ exsufflation during the sleep in order to observe any improvements.

Results. Only 2 of them had used early non-invasive ventilation, cough assist machine or a suction device for the secretions.

2 of the patients were tracheostomized, due to the lack of respiratory protocols among the intensive unit care. 1 of them died at the age of 14 months, even she had received 2 doses of Nusinersen treatment (anti-sense oligonucleotide that enables survival motor neuron protein).

1 patient received good respiratory management during a pneumonia episode and had no motor/ respiratory regress after the acute disease.
\end{abstract}

Conclusions. The respiratory management is very important and it is absolutely necessary in all patients with/ without treatment.

Keywords: spinal muscular atrophy, neuromuscular disease, respiratory management, sleep hypoventilation 
P7 - PRESENTATION OF THE FUGL MEYER ASSESSMENT SCALE AND RELATED SUGGESTION IN ORDER TO ENHANCE ITS LEVEL OF IMPLEMENTATION IN INNER NEUROREHABILITATION UNITS

$\underline{\text { Mihaela MANDU }^{1}, \text { Elena CONSTANTIN }}{ }^{1}$, Cristinel Dumitru BADIU ${ }^{1,2}$, Cosmin Daniel OPREA ${ }^{3}$, Cristina DAIA ${ }^{1,2}$, Gelu ONOSE ${ }^{1,2}$

Corresponding author: Mihaela Mandu, mihaelamandu37@yahoo.com

1. "Bagdasar Arseni” Clinical Emergency Hospital, Bucharest

2. "Carol Davila" University of Medicine and Pharmacy, Bucharest 3. "Filantropia" Municipal Hospital, Craiova

Abstract

Introduction. Cerebrovascular accidents represent a major cause of morbidity, mortality and disability in the adult population. After a stroke, many patients remain with a serious deficit including motor, sensory and balance, which affect their quality of life. To quantify these deficits, various tools have been created, such as the Fugl Meyer assessment scale (FMA). It was elaborated in 1975 by Fugl Meyer and his colleagues, who observed the fact that there was a lack of exhaustive quantification of recovery progress in patients who suffered a stroke. FMA is a valid, reliable, responsive, and widely used standardized observational rating scale with ordinal data that assesses the sensorimotor, balance, joint pain and joint motion impairment.

\section{Methods and material}

This paper is a try to extend the implementation of this scale in the inner neurorehabilitation units, considering literature related resources (some updated too), aiming to supplement the assessment tools bundle to be availed; this would facilitate more complete evaluated cases in clinical studies. The maximum score that can be achieved is 226 points. A particularity of this scale refers to the positive relation between functionality and its partial and global scores, but regarding pain too but obviously this is a negative item. FMA comprises five domains: sensorimotor functioning, balance, joint range of motion, joint pain. The rating is based on direct functional quantified observation of the motor performance at each item using a 3 point ordinal scale $(0=$ can not perform, 1=performs partially, 2=performs fully). The time to be performed is about 45 minutes.

\section{Results}

Considering on one hand its above mentioned qualities, but on the other its rather chronophagic paradigm, we propose a splitting of its achievement in each tested by FMA patient of its specific measurement items between doctors and licensed kinesio-therapists - preliminary specific training based. In this purpose, we have initiated a detailed correspondence with the international professionals in charge of FMA use.

\section{Conclusions}

Pending on the outcome of the above mentioned correspondence, hopefully we could succeed in enhancing FMA application, but within a reasonable time frame within the clinical rhythm.

Key words: Fugl-Meyer assessment scale, medical doctors, kinesio- therapists, enanched implementation suggestion.

\section{Selected references:}

1. APTA (2011). Compendium of Instructions for Outcome Measures - StrokEDGE Taskforce. APTA Neurology - pp: 51, 55-67, 70-74

2. Nubia E. Barbosa, Sandra M. Forero, Claudia P. Galeano, Edgar D. Hernández, Nancy S. Landinez, Katharina S. Sunnerhagen \& Margit Alt Murphy (2019) Translation and cultural validation of clinical observational scales - the Fugl-Meyer assessment for post stroke sensorimotor function in Colombian Spanish, Disability and Rehabilitation, 41:19, 2317-2323, DOI: 10.1080/09638288.2018.1464604

3. Fugl-Meyer AR, Jaasko L, Leyman I, et al. The post-stroke hemiplegic patient. 1. A method for evaluation of physical performance. Scand J Rehabil Med. 1975;7:13-31. 
P8 - Complex oral rehabilitation in an elderly patient with periodontal disease who exercises regularly

\title{
ALEXANDRU BOGDAN-CĂTĂLIN ${ }^{1}$, ALINA SIMONA ȘOVREA, ${ }^{1}$ ANNE-MARIE CONSTANTIN $^{2}$, ADINA BIANCA BOȘCA ${ }^{2}$, CARMEN GEORGIU ${ }^{2}$, MONICA POPA ${ }^{1}$
}

"Iuliu Hațieganu” UMPh Cluj-Napoca, Department of Hygiene

"Iuliu Hațieganu” UMPh Cluj-Napoca, Department of Histology “Iuliu Hațieganu” UMPh Cluj-Napoca, Department of Pathological Anatomy

\begin{abstract}
Background. Physical exercise, balneoclimatic procedures, as well as the maintenance of individualized local hygiene conditions prove to be favorable to health even at advanced ages, when these are kept within tolerance limits, having a beneficial impact, including on periodontal tissues.

Aims. The increase of the mechanical strength of teeth involves providing periodontal support adapted to composite restoration treatment, as well as improving local facial appearance, which plays a role in increasing the patient's quality of life.

Materials and methods. Poster presents a complex oral rehabilitation situation, evidencing periodontal disease and its therapy at an advanced age, in the case of a person who exercises regularly, a former high-performance skier.

Results. Senescent periodontal involution can develop within functional limits (absence of inflammation and tooth mobility), in the context of a healthy lifestyle, which includes: antioxidants, physical exercise, individualized oral hygiene through the use of auxiliary hygiene means, etc.

Senescent periodontal involution allowed us to perform complex individualized oral rehabilitation, with a role in reinforcing dental-periodontal support, with excellent clinical results.

Conclusions. The fact that the patient still exercises regularly, attends balneoclimatic therapy and strictly observes the diet prescribed by nutritionists continuously provides her with antioxidant intake having a visible impact, including on periodontal tissues.

Taking into account geriatric dental particularities and adequate periodontal and prosthetic treatment by stage, associated with patient compliance, can lead to positive results, consisting of a long-term improvement of the quality of life.
\end{abstract}

Key words: senescent periodontal involution, prosthetic treatment in case of senescent periodontal involution, complex oral rehabilitation of patients with senescent periodontal involution 
P9 - MORBIDITY BY OSTEO-MUSCULO-ARTICULAR DISEASES IN THE

OCCUPATIONAL ENVIRONMENT IN MARAMURES COUNTY. THE

IMPORTANCE OF MEDICAL RECOVERY AND RECORDS THROUGH

ELECTRONIC DATA MANAGEMENT SYSTEMS

\author{
Dorin-Gheorghe TRIFF ${ }^{1}$, Simona POP ${ }^{2}$
}

1. Occupational Diseases Department, Emergency County Hospital Baia Mare, email triffdorin@gmail.com 2. Rehabilitation Laboratory, Physical Medicine and Balneology, „Dr.Gavril Curteanu” Clinical Town Hospital, Oradea

\begin{abstract}
Introduction The importance of osteo-musculo-articular diseases in occupational environments results both from the fact that they cause temporary inability to work, with frequent subsequent relapses, but also by affecting the active population, especially often due to the fragmentary or ineffective involvement of the medical rehabilitation services at least after the diagnosis of these diseases. The poor collaboration between the occupational health services and the medical rehabilitation services, having objective causes, through legislative and administrative obstacles, presents high social costs compared to those related to the implementation of functional procedures that ensure the recovery and maintenance of work capacity in patients diagnosed with such conditions.
\end{abstract}

Materials and Methods The criteria for delineating an osteo-musculo-articular disease as a professional or professionrelated disease is difficult to achieve at present. Using workplace risk assessment methods, in the absence of electronic support for the medical file (with standardized data on workplace exposures and health status), makes these assessments rather hypothetical. Incorporating illnesses based on workplace records requires the use of formulas and indicators (relative risk of the exposed and unexposed, morbidity indicators, etc.) correlated with the data present at public health or private health insurance providers.

Results. The use of electronic health records modules can generate evidence on the basis of which the calculation of the professional etiological fraction, exposure data and morbidity can be the correct framing of the osteo-musculo-articular conditions that allow for coverage (possibly by a differentiated amount) of the medical rechabilitation services, essential in treating and preventing relapses in these patients. The proportion of osteo-musculo-articular diseases in the occupational morbidity of Maramures County over the last 5 years shows an increasing trend (figures in brackets illustrate the proportion of these diseases in the total occupational diseases) is as follows: 2014 (60.71\%), 2015 (79. 41\%), 2016 (75\%), 2017 (85.7\%), 2018 (82.14\%). If in 2016, the patients hospitalized with osteo-musculo-articular conditions accounted for $14.2 \%$ of the total continuous hospitalzations with occupational diseases, in 2018 their share was $21.37 \%$ of the total hospitalized patients with occupational diseases. Osteomusculo-articular diseases undeclared as occupational diseases together with the diagnosed professional osteo-musculoarticular diseases present in $82.73 \%$ of hospitalized patients show the importance and the close-toreality proportion of these diseases in occupational morbidity.

Conclusions. The reimbursement of health care rehabilitation services through the health insurance system as well as through the accidents and occupational disease insurance fund or directly covered by the employer are currently, by using modules of the Electronic Health File, a possibility whose application depends only on the decision makers' determinism to facilitate the recovery of workers with osteo-musculo-articular diseases. The importance and proportion of osteo-musculo-articular diseases (professional or professionrelated) requires both the extension of the medical rehabilitation services and the increase of workers' accessibility to them, the collaboration between the medical and occupational health specialists as well as the efficient use of the medical records regarding data and coverage of the services, through the progressive use of Electronic Health File modules.

Key-words: medical rehabilitation service, professional disease, profession-linked disease, professional morbidity, Electronic Health File 
P10 - New evidence on the effects of pelotherapy on local microcirculation

\author{
Mihaela Antonina CALIN ${ }^{1}$, Marian Romeo CALIN ${ }^{2}$, Constantin MUNTEANU ${ }^{3,4}$
}

Corresponding author: Mihaela Antonina CALIN, E-mail: micalin@inoe.ro

1. „National Institute of Research and Development for Optoelectronics INOE 2000”, Magurele, Romania

2. "Horia Hulubei National Institute for Physics and Nuclear Engineering - IFIN HH", 30 Reactorului Str,

Bucharest-Magurele, Romania

3. Romanian Association of Balneology

\title{
Abstract
}

4. Clinical Emergency Hospital "Bagdasar-Arseni”, Bucharest, Romania

\section{Introduction}

Pelotherapy or mud therapy is a balneological method used from ancient times, which triggers local tissue and general functional reactions, inhibiting or activating some intermediate enzyme and metabolite systems, but its mechanisms of actions on certain pathologies are still not completely understood. Nowadays, testing and understanding the response of the human body to pelotherapy continues to be a challenge for specialists seeking alternative treatment solutions for different pathologies. The present study was designed to assess the effects of pelotherapy on local microcirculation using hyperspectral imaging (HSI) and a spectral unmixing model based on a modified Beer-Lambert law.

\section{Materials and Methods}

A total of ten healthy volunteers aged 35 to 60 years were included in this study. Peloid collected from the Techirghiol Lake, Romania was applied on the dorsum of the left hand of each volunteer for $20 \mathrm{~min}$. A pushbroom hyperspectral imaging system was used to acquire images of the volunteers 'hands at different time moments of the pelotherapy: $0 \mathrm{~min}, 5 \mathrm{~min}$ and, $20 \mathrm{~min}$ and after $20 \mathrm{~min}$ post-pelotherapy. Oxyhemoglobin and deoxyhemoglobin distribution maps on the hands of the volunteers at all these time moments of pelotherapy were generated from hyperspectral data. Oxygen saturation maps were also generated at the same time moments.

\section{Results}

The results have revealed that pelotherapy improves local circulation, both arterial (evidenced by increased oxyhemoglobin concentration) and venous return (caused by decrease in deoxyhemoglobin concentration). This could bring new insight into the physiological response to pelotherapy and may become a step forward in understanding its mechanism of action.

\section{Conclusions}

In conclusion, our results show that pelotherapy is effective in improving local microcirculation, at least in healthy volunteers. This opens the door for new research in both pelotherapy and hyperspectral imaging, and the results of these research would not only interest the medical world, but also extend applications of hyperspectral imaging from remote sensing to medical fields.
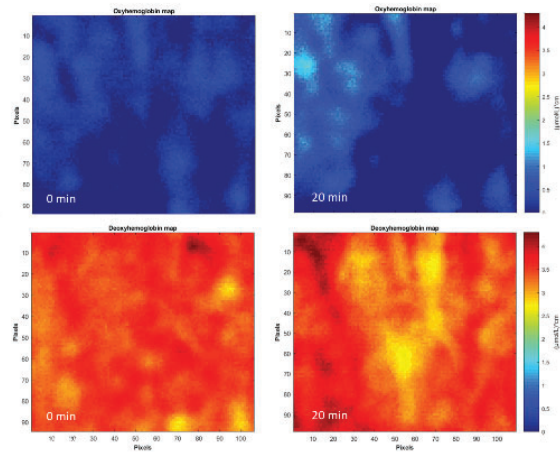

Fig. 1. Oxy- and Deoxyhemoglobin maps of a hand region before and after pelotherapy 


\title{
P11 - The effectiveness of balnear treatment in the management of psoriasis
}

Izabela LAZĂR ${ }^{1}$, Gabriela DOGARU ${ }^{1,2}$

Corresponding author: Izabela LAZĂR

1. Clinical Reabilitation Hospital, Cluj-Napoca, Romania 2."Iuliu Haţieganu" University of Medicine and Pharmacy Cluj-Napoca, Romania, Department of Medical Rehabilitation

\begin{abstract}
Introduction. Psoriasis is a chronic inflammatory disease which is accompanied by social and emotional complications leading to disability. There is no cure for psoriasis, however, various treatments can help control the symptoms, such as steroid creams, vitamin D3 creams, ultraviolet light and methotrexate. All of these treatments have side effects and can't be used for long periods of time. Psoriasis is also associated with an increased risk of psoriatic arthritis, cardiovascular disease, lymphomas, Crohn's disease and depression. Psoriatic arthritis can affect up to 30 percent of individuals with psoriasis, which raises the importance of finding effective treatments with less side effects. Balneotherapy or the use of mineral waters or clays can be seen as an alternative, a safe and natural treatment.

Material and method. This study aims to be an update on the balneotherapy of psoriasis. Search was conducted on PubMed, Medscape and Cochrane. Only studies that focus on the actions of thermomineral products (waters, muds, gases, steam) in the treatment of psoriasis were taken into consideration.

Results and discussions. All studies show that after balneotherapy there is a significant decrease in Psoriasis Area Severity Index (PASI), associated with a significant reduction of interleukin-8. Out of the mineral waters, sulphurous mineral water is the most used in psoriasis, as it was found to have beneficial antiinflammatory, keratolytic, and antipruriginous effects and also possess antibacterial and antifungal properties. Conclusions. Balnear treatment is effective for reducing the symptoms of psoriasis and improve the patient's well-being. It is important to associate standard therapies with balneological therapies for the benefit of the patients, and to inform them of this possibility.
\end{abstract}

Key words: balnear treatment, balneotherapy, psoriasis, mineral water, sulfur water 
P12 - CORRELATIONS OF OSTEOMUSCULO-ARTICULAR DISEASES WITH WORK ABILITY, PERCEIVED SELF EFFICACY AND OCCUPATIONAL STRESSORS AT A REGULAR MEDICAL CHECK-UP IN PRE-UNIVERSITY EDUCATION UNITS

\author{
Dorin-Gheorghe TRIFF ${ }^{1}$, Mușata Dacia BOCOȘ²
}

1. Emergency County Hospital Baia Mare, email triffdorin@gmail.com

Abstract

2. Babes-Bolyai University, Faculty of Psychology and Educational Sciences

\title{
Introduction
}

In practice, the evaluation of osteo-musculo-articular diseases and occupational stress is achieved through the clinical examination and questionnaires.

\section{Materials and Methods}

235 questionnaires were administered during periodic medical checkup in a a secondary school and a two highschools. Highschools have the heaquarters in urban area while secondary school has the heaquarter in rural area. The questionnaires assessed the workers' occupational stress, individual characteristics, sense of self-efficacy and work ability(using Work Ability Index-named WAI, elaborated by Finnish Institute of Occupational Health). 6 items of work ability index scale evaluate the presence of osteo-musculo-articular diseases. The presence (by yes/no) and the number of groups of osteo-musculo-articular diseases acordig with WAI were recorded. The presence of osteomusculo-articular diseases at clinical examination in occupational medicine checkup ( anamnestic and clinical) were also mentioned. Data analysis (software) used were Epi Info v. 3.5.3, EXCEL 2010, SPSS v 16.0. Statistical tests used: Kruskal-allis test, Mann-Whitney test (U test), ANOVA, Kruskal-Wallis test and Spearman correlation coefficient $(\rho)$ for correlations between questionnaires variables. For $\rho$, the notation: $* *$-means that correlation is significant at the 0.01 level (2-tailed); * -means that correlation is significant at the 0.05 level (2-tailed). $p$ value was significant at 0.05 . Ten possible causes of stress at work were evaluated ( by their frequency in the workplace ) as following: unable to change unpleasant aspects, communication with superiors, responsibility at work, risks of disease, wage level, risks of injury, relationships with other employees, work tasks, work schedule, daily completion of documents.

\section{Results}

In one highschool (with 131 respondents) perceived self efficacy has no significant correlation with the presence of osteo-musculo-articular diseases. WAI significantly negatively correlates with the following: presence of osteomusculo-articular diseases (mentioned in WAI questionnaire) $(\rho=-0.559 * * ; p<0.001)$, number of osteo-musculoarticular diseases (mentioned in WAI questionnaire) $\left(\rho=-0.567^{* *} p<0.001\right)$, presence of osteo-musculo-articular diseases at clinical examination $(\rho=-0.452 * * p<0.001)$. In the second highschool(with 72 respondents) number of osteomusculo-articular diseases (in WAI) correlates positively with perceived self efficacy $\left(\rho=0.585^{*}, p=0.022\right)$. In both high schools lenght of employment in unit significant positively correlates with number of osteo-musculo-articular diseases (mentioned in WAI ( $\mathrm{p}=0.001$ in first highschool and $\mathrm{p}=.035$ in the second highschool). Age variable does no correlates with the presence and the number of the osteo-musculo-articular diseases. In secondary school (rural area, with 32 respondents) only 3 osteo-musculo-articular diseases ware recorded.

\section{Conclusions}

In secondary education age does not differentiate workers from the point of view of workplace stress levels, general self-efficacy, presence of osteo-musculo-articular diseases or work capacity. Lenght of employment in unit positively associates with number of osteo-musculo-articular disease in both highschools. The small proportion of osteo-musculoarticular diseases in rural area can be explained by protective factor represented by daily physical exercise (workind in agriculture) of secondary school employees.At present, the complexity of factors involved in the genesis of osteomusculo-articular diseases and stress at work requires a reserve in generalizing conclusions, although in the three randomly chosen school units, there are some concordant results which deserve further studied through the additional contribution of other factors that influence osteo-musculo-articular diseases, workplace stress, work ability and selfefficacy. The importance of osteo-musculo-articular diseases is underlined by the relative high proportion of these diseases, diverse associations with lenght of employment in unit, work ability, , self-efficacy, stress factors and conclude the importance of collaboration of medical rehabilitation and occupational medicine services.

Key-words: osteo-musculo-articular disease, work ability, self-efficacy, stress factors 
P13 - PREVENTION OF LUMBAR DISC HERNIATION IN YOUNG ADULT POPULATION: A PRACTICAL APPROACH

Doroteea Teoibas-Serban', Valentin Stan ${ }^{4}$, Dan Blendea ${ }^{2,3}$

Corresponding author: Doroteea Teoibas-Serban: doroteeateoibas@yahoo.com

1. SES Center of Rehabilitation, physical medicine and balneology Bucharest

2. Clinical Emergency Hospital Ilfov Bucharest

3. Univeristy of Medcine "Titu Maiorescu"

\begin{abstract}
Introduction. Lumbar disc herniation increases in younger adults which workout at the gym. Most of the time, they are unaware of the risk involving certain exercises and they force-out the workout empowered by their young age and their strength. If certain exercises are done systematically, the disc structure starts to alter, and lumbar disc herniation is soon to appear.

Materials and Method. The medical research literature provides us with the correct exercises which are to be made after the diagnosis of lumbar disc herniation, but there aren't so many which provide prevention exercises. Not all gym instructors are qualified to assess the risk of each person pulling weights or doing exercises that are to great for the strength of each individual. The ideal scenario is for the individual to consult with a rehabilitation specialist or a kinesis-therapist before starting exercising at the gym, but this doesn't happen very often.

Our solution is to provide images with exercises that they shouldn't do, and exercises that they should do to increase segmental spine stability, working on the ligamentous subsystem, the musculotendinous subsystem and the neural control subsystem in order to prevent disc structure alteration, and disc herniation.

Results. The images will be printed out on posters and small fliers which are to be handed out at gyms to make the population aware of the risk of disc herniation which they expose themselves to doing exercises unfit for their strength.

Conclusion. By making the young adult population aware by simple self-explanatory images, we hope to decrease the incidence of lumbar disc herniation in this group of population.
\end{abstract}




\title{
P14 - Development a Monitoring Device for Arm Rehabilitation
}

\author{
Călin Corciovă ${ }^{1}$, Cătălina Luca $^{1}$, Robert Fuior ${ }^{1}$, Flavia Corciovă ${ }^{2}$
}

Corresponding author: Călin Corciovă, E-mail: calin.corciova@bioinginerie.ro

${ }^{1}$ Faculty of Medical Bioengineering, University of Medicine and Pharmacy "Grigore T. Popa” Iasi, Romania

${ }^{2}$ Institute of Cardiovascular Diseases "Prof Dr. George IM Georgescu", Iasi, Romania

Abstract

Introduction. Rehabilitation process due to stroke or accident related injuries are based on clinical assessment tools which can be executed by self-report (home-based) and observer-rated (done at rehabilitation centre). Observer rated by caregivers can be time consuming and patients require to have repeated observations at rehabilitation centre which can be costly. However, early home-based rehabilitation proved to promote a better physical health because it appeared to permit motor and functional gains that occurred with natural recovery and satisfaction with community integration. Continuous monitoring of physical activity is an important subject in the area of rehabilitation. The results obtained from these observations can be used to determine the progress and effectiveness of a rehabilitation program.

Material and method. The assistive device is an alternative for monitoring which incorporate many hightech systems into rehabilitation. That system involves attaching devices to the affected human limbs in order to monitor patient's physical activity. Miniaturized sensors such as accelerometers, flex sensors and force sensitive resistors are widely used in developing this assistive device. Accelerometer is a device which measures acceleration indirectly through inertial force. Due to this ability, accelerometers have been used to track motion of human. Flex sensor can effectively measure movement and flexibility of muscle. Force sensitive resistor can detect flexion and extension of individual muscles. These sensors proved effective to measure various physical activities parameters.

Results and discussions. Any movements due to arm bending, sudden arm acceleration and muscle movement activity will be detected and sent to Arduino microcontroller and processed to be transmitted to PC via USB connection for online real - time data logging or SD card data logging (non-USB connection).

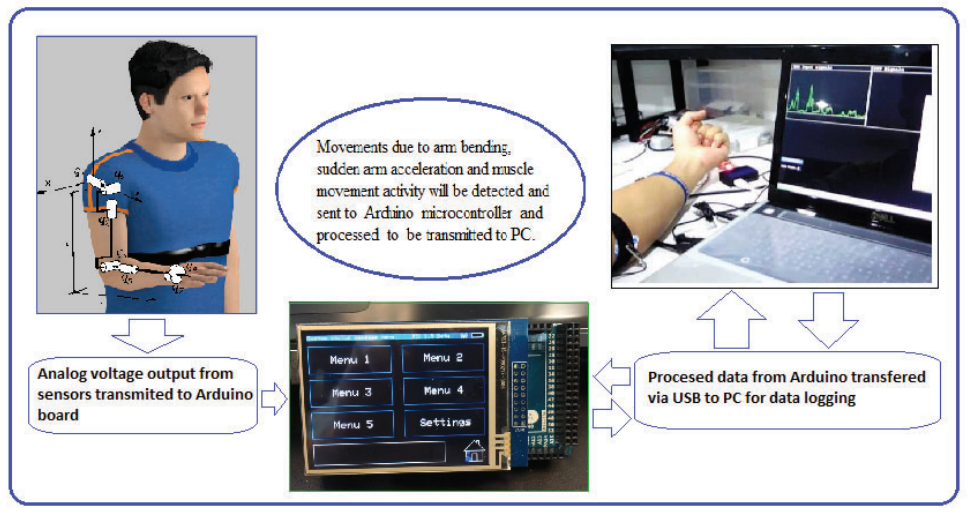

Fig. 1. System block diagram

Conclusions. The designed system is low cost, compact and does not restrict movement during usage. The proposed system is easy to be attached onto arm with minimal external assistance. It has data logging systems which can store data into PC for certain period of time that can be used by physical therapist for further analysis.

Key words: arm rehabilitation, assisting device, flex sensors, microcontroller, electromyography

References:

1. Janne M. Veerbeek, Anneli C. Langbroek-Amersfoort, Erwin E. H. van Wegen, Carel G. M. Meskers, Gert Kwakkel, Effects of Robot-Assisted Therapy for the Upper Limb After Stroke: A Systematic Review and Meta-analysis, Neurorehabilitation and Neural Repair 2017, Vol. 31(2) 107-121 
P15 - Cardiovascular rehabilitation: challenges in a case of acute myocardial infarction and familial hypercholesterolemia

Simona Daniela Zavalichi ${ }^{1}$, Marius Andrei Zavalichi ${ }^{2,4}$, Sorin Stratulat ${ }^{3,4}$, Florin Mitu $^{1,4}$

Corresponding author: Simona Daniela Zavalichi, E-mail: simona.climescu@yahoo.com

${ }^{1}$ Rehabilitation Clinical Hospital, Iași, Romania

2“Prof. Dr. George I.M. Georgescu” Heart Diseases Institute, Iași, Romania

${ }^{3}$ C.F. Clinical Hospital, Iași, Romania,

${ }^{4}$ University of Medicine and Pharmacy "Gr. T. Popa”, Iasi, Romania

\begin{abstract}
Introduction: Familial hypercholesterolaemia $(\mathrm{FH})$ is a genetic disorder estimated by recent studies to have a frequency of 1 in 500 individuals. FH consists of elevated levels of LDL-cholesterol, usually resistant to hypolipemiant therapy or general lifestyle interventions like weight loss or physical exercise. FH often affects relatively young individuals and predicts an early cardiovascular risk onset that leads to possible major cardiovascular events.

Materials and methods: We present the case of an overweight, former smoker, 49-year-old male with $\mathrm{FH}$ (father died at 43 of acute myocardial infarction and his daughter with high levels of LDL-cholesterol) who presented in our clinic to initiate the cardiovascular rehabilitation program after having suffered a cardiac arrest due to an acute inferior myocardial infarction. He was hemodynamically stabilised and three consecutive coronary revascularizations were performed in a PCI centre. After two weeks the patient was included in the rehabilitation phase II program. The patient's evolution was favourable, confirmed by the cardiopulmonary exercise test parameters like workload, peak oxygen content, respiratory exchange ratio, maximum heart rate, heart rate reserve and blood pressure. However, lipid levels remained elevated, despite proper therapy, therefore a cholesterol intestinal absorption inhibitor was added to statin and fibrate, with periodic paraclinical monitoring.
\end{abstract}

Results and discussions: The cardiovascular rehabilitation program of the patient aimed not only to regain his functional capacity, but also to improve the dyslipidemic profile by physical exercise and lifestyle changes. The milestone remains diagnosing the underlying genetic mutation that can lead to a properly guided therapy and extending the investigations to the patient's family.

Conclusions: The initiation of a cardiac rehabilitation program in a patient with multiple risk factors, personal and family history of hyperlipoproteinemia and ischaemic heart disease offers important benefits in terms of accelerated recovery, exercise performance regaining and recurrent major cardiac events prevention.

Key words: cardiovascular rehabilitation, familial hypercholesterolaemia, acute myocardial infarction. 
P16 - Influences and consequences resulting in addictions in general and to chronic alcoholism, especially for patients with spinal cord injury

\author{
Simona-Isabelle STOICA ${ }^{1,2}$, Ioana TANASE ${ }^{2}$, Gelu ONOSE ON, $^{1,2}$
}

1. University of Medicine and Pharmacy "Carol Davila" (UMPCD), in Bucharest, Romania

2 Teaching Emergency Hospital "Bagdasar-Arseni” (TEHBA), Bucharest, Romania

\begin{abstract}
Introduction

Spinal cord injury can be a cause of severe disability, with important consequences at the individual and social levels ${ }^{(1)}$.

Causes are often produced by falls or road accidents; and addictions (particularly chronic etitism) also increase the risk of vertebral-medullary lesions ${ }^{(1)}$

Materials and Methods

With the opinion of the TEHBA Ehics Commission (no.17464/14.06.2019), we will use specific tests (DAS, Hamilton, SMAST, QoL, Brick, AUDIT, CAGE, ASIA, Ashworth, PENN) and we will question a group of patients admitted to the SCUBA Neuro-Muscle Recovery Clinic after being treated in the Spinal Neurosurgery Service for acute and subacute vertebral and medullary trauma.

\section{Results}

We intend to evaluate the link between addictions (especially ethanol), the risk of vertebro-medullary trauma, and the underlying subacute evolution of patients with this pathology.

\section{Conclusions}

Substance abuse (especially ethanol) increases the risk of vertebro-medullary trauma and is a serious public health problem.

\section{Bibliography}

1. Bárbara-Bataller E, Méndez-Suárez JL, Alemán-Sánchez C, Sánchez-Enríquez J, Sosa-Henríquez M. Change in the profile of traumatic spinal cord injury over 15 years in Spain. Scand J Trauma Resusc Emerg Med. 2018;26(1):27. Published 2018 Apr 5. doi:10.1186/s13049-018-0491-4
\end{abstract}


P17 - BIOMECHANICAL DYSFUNCTIONS OF THE FOOT - MAJOR IMPACT ON THE KINETIC CHAIN

\title{
Roxana Dumitrascu, Ana Maria Bumbea, Carmen Albu, Otilia Rogoveanu, Catalin Bostina, Rodica Traistaru, Borcan Madalina
}

Corresponding author Ana Maria Bumbea anamariabumbea@yahoo.com

\begin{abstract}

\section{Introduction}

We all know common foot pathologies : Bunion (hallux valgus), Morton's Neuroma, hammer toes, Heel Spur Syndrome, Achilles Tendonitis, flat feet, what we do not know is how and when they start to have an effect on the whole kinematic chain, from pressures, determined by foot structure and function to abnormal locomotion.
\end{abstract}

\section{Materials and method}

The structural abnormalities of the foot may cause a compensatory movement at the subtalar joint during gait cycle. Arch alignment has been assessed using clinical observation, dynamic footprint, were the peak pressures and the time of peak pressures were analysed and radiographic measurements.

During walking, the center of pressure in the normal foot, moves from lateral edge of the heel to the medial forefoot. If the foot pronates the pathway is to move medially, if it supinated it will tend to move toward the lateral border.

For the rehabilitation we followed the kinematic gait, using 3 types of orthoses (accommodative, semi-rigid and rigid) and a special kinetic program .

\section{Results and discussions:}

All the studies show that individuals with foot and ankle pain have multiple co-existing impairments in alignment, motion, load distribution and muscle performance.

Lower extremity function during most weight bearing activities of daily living occurs in a closed kinematic chain, and consequently may be interdependent.

\section{Conclusions}

This regional bond of the lower limb may be evident during evaluation, and may offer important strategies for the rehabilitation. This interdependence is reflected in the connexion between proximal (hip or knee) and distal (foot and ankle) motor function. 
P18 - Medical rehabilitation in post-stroke spastic hemiparesis in young patients

Otilia Rogoveanu${ }^{1}$, Gherghina Florin ${ }^{1}$, Caimac Dan ${ }^{1}$, Trifu Ramona ${ }^{2}$, Cruceru Andra ${ }^{2}$, Beldie C ${ }^{2}$

Corresponding author Otilia Rogoveanu: anamariabumbea@yahoo.com

${ }^{1}$ Department of Medical Rehabilitation, University of Medicine and Pharmacy of Craiova, Romania

${ }^{2}$ Department of Medical Rehabilitation, Emergency Clinical County Hospital of Craiova, Romania

\begin{abstract}

\section{Introduction}

Ischemic stroke affects the central nervous system and is caused by disorders of the cerebral circulatory system that consist of diminished or interrupted cerebral arterial blood flow. The irreversible necrosis of the cerebral tissue generates neurological impairment in the affected territory which leads to coordination, balance and walking disorders.
\end{abstract}

\title{
Objectives
}

The main objective of this study is to evaluate the importance of a complex medical rehabilitation programme in a patient with post-ischemic stroke spastic hemiparesis and the evolution of the clinical symptoms during this time frame.

\section{Material and methods}

A 34 year-old patient diagnosed with post-ischemic stroke spastic hemiparesis is included in a medical rehabilitation plan including the following methods: kinetic therapy using proprioceptive neuromuscular facilitation (PNF), occupational therapy and orthotics for the affected hemibody.

\section{Results}

Throughout the study, the algo-functional stiffness of the affected hemibody was diminished, the Activities of Daily Living (ADL) score was improved and also spasticity evaluated on the Ashworth scale was diminished.

\section{Conclusions}

The rehabilitation methods utilized for treating post-ischemic stroke complications generated a positive impact in the patient's life. Therefore, the motor deficit was diminished and the amplitude of movements was significantly increased. Furthermore, the patient managed to perform daily activities independently. 


\title{
P19 - PERIPHERAL MAGNETIC STIMULATION - A CHALLENGE IN VERTEBRAL POSTTRAUMATIC RECOVERY
}

Ana Maria Bumbea, Otilia Rogoveanu, Roxana Dumitrascu, Bogdan Stefan Bumbea, Catalin Bostina, Albu Carmen, Borcan Madalina

Corresponding author Ana Maria Bumbea: anamariabumbea@yahoo.com

${ }^{1}$ Department of Medical Rehabilitation, University of Medicine and Pharmacy of Craiova, Romania

${ }^{2}$ Department of Medical Rehabilitation, Emergency Clinical County Hospital of Craiova, Romania

\begin{abstract}

\section{Introduction}

The authors presented a case of an 18-year-old patient with thoracic and lumbar vertebral trauma after a car crash.
\end{abstract}

\section{Material and method:}

The patient underwent a thoracolumbar trauma that required neurosurgical emergency intervention to stabilize the column spine. Then followed a recovery phase In the Neuromuscular Rehabilitation Clinic of BagdasarArseni Hospital.

At 8 weeks from the trauma, he is presented at the Neurological Rehabilitation Clinic Craiova with an initial assessment of Frankel A, being stationary at the time of the neurosurgical intervention. The patient presents the clinical status of paraplegia with complete spinal cord injury.

Several physical procedures were applied during hospitalization, the most used being electrostimulation with exponential currents to which the patient responded therapeutically. Thereafter, repetitive magnetic stimulation therapy applied to lower limb muscles was initiated: quadriceps, anterior tibialis and sural triceps for 5 minutes per muscle group. In addition, he received a kinetotherapy program for transfer education and bladder education.

\section{Results}

The patient developed muscle contraction when applying electrostimulation with exponential currents and applying repetitive peripheral magnetic stimulation. Although magnetic stimulation produces a rectangular current, it seems that in patients with proven denervation, muscle contraction is obtained, either by the recruitment of responsive muscle fibres or by the generation of slope currents. During hospitalisation the patient initiates movement from the proximal muscles of the lower limbs, the central pivots, possible activity only after prolonged rest. Patient evolution was favourable with the application of specific therapy and the ability to pass Frankel A in class Frankel B class in short time.

\section{Conclusions}

Early application of muscle stimulation therapies through biofeedback with effective patient participation can generate a favourable status of motor deficit recovery. Aspects require further studies and sustained therapy in order to be statistically proven the efficacy of the treatment. One can also discuss the frequency of the magnetic field, knowing that certain frequencies are recognized to be curative, but this is also a field of future study. 


\title{
P20 - KNEE ARTHROPLASTY RECOVERY OF AN CANCER PATIENT
}

\author{
Dănuţ PĂCURAR', Mihaela Ramona PĂCURAR²
}

(1) Carei Municipal Hospital (2) Medena Clinic Oradea

\section{Abstract}

\section{Introduction}

The knee joint is the most complex joint of the human body. Compared to other large joints (coxofemoral and scapulohumeral), it is less protected by soft parts, that explains the frequency of its exposure to external trauma. It is also highly active in static and locomotion. Osteoarthritis at this level is one of the major chronic diseases commonly found in people over 50 years of age. According to statistics provided by the World Health Organization, hundreds of millions of people suffer from bone and joint diseases, including osteoarthritis, their number is continually increasing, and is estimated that this number will be doubled by 2020 . Endoprosthetic arthroplasty is defined as a reconstructive surgery with prosthetic replacement of articular components and bone sacrifice. It is an surgical intervention that restores joint mobility as well as the normal functioning of ligaments, muscles and other periarticular structures that perform joint movement.

METHOD: We will present the case of a 59-year-old female patient, known with a total cemented right knee arthroplasty for advanced gonarthrosis, performed 3 months ago. She was admitted for the recovery treatment. At admission, she presents: mechanical pain in the right knee, pain in the lumbar and right hypochondrium, as well as secondary vision disturbances on the left. Associated, the patient has undergone surgical removal of a brain neoplasm of the sellar region 7 years ago with no evidence of recurrence.

RESULTS: At admission: $\mathrm{BP}=140 / 80 \mathrm{mmHg}, \mathrm{HR}=60 / \mathrm{min}, \mathrm{SO} 2=98 \%$, afebrile, jaundice, painful palpation in the right hypochondrium. Examining the locomotor apparatus: flattening in the physiological curves of the spine, bilateral muscle contraction p.v. dorsal-lumbar, painful lumbar flexion, negative bilateral S. Lassegue, equal ROT, symmetrical, mild muscular hypotrophy at lower right leg, normal aspect of postsurgical scar in the anterior knee region, active-passive knee flexion $90^{\circ}$, straight knee extension within normal limits, without local celsian signs, bilateral unipodal support possible. Biologically: hepatocitolysis, cholestasis, hyperbilirubinemia, ESR $=2 x N R$, hypochromic microcytic anemia, and mild hypocalcaemia. ECG: RS, 75 / min, without pathological elements. We have compiled the recovery sheet as follows: kinetotherapy, occupational therapy and masotherapy with the reserve of suspicion of a possible neoplastic digestive pathology. It is apropiate to mention that the patient was asymptomatic when the arthroplasty was performed and the biological values were within normal parameters. We perform an abdominal-pelvic CTscan because the ultrasound was inconclusive, revealing a pancreatic mass in the cephalic region that encompasses the hepatic artery, splenomegaly,mesenteric confluent and proximal portal vein thrombosis, a non-specific $4 \mathrm{~mm}$ micronodulary lesion at the base of the right lung. We stopped the rehabilitation treatment and transferred the patient to the Oncology section.

CONCLUSIONS: The peculiarity of the case consists in the overlapping of two pathologies - pancreas neoplasia and the recent arthroplasty, on a previously asymptomatic patient. Pancreas neoplasia is one of the most aggressive forms and is often diagnosed in advanced stages, as was the case here, but which greatly limits the recovery program. 
P21 - THE IMPACT OF OSTEOARTICULAR PATHOLOGY IN POSTSTROKE RECOVERY

Dănuţ PĂCURAR', Mihaela Ramona PĂCURAR²

(1) Carei Municipal Hospital (2) Medena Clinic Oradea

\section{Abstract}

\section{Introduction}

Stroke is a neurological disorder involving the obstruction of blood flow to the brain with cellular destruction. There are two major mechanisms: ischemia and hemorrhage. Ischemic stroke is accounted for approximately $85 \%$ of total strokes. Depending on the producing mechanisms, they are divided into strokes by thromboembolic occlusive mechanism and hemodynamic strokes. Hemorrhagic strokes account for about $15 \%$ of all strokes, but with a $40 \%$ mortality rate from total stroke deaths. Stroke remains a major cause of morbidity and mortality. It is ranked third as the cause of death in economically developed countries, and for the elderly it is the main cause of neurological disability. Forecasting studies show that this condition increases from year to year, both in incidence and prevalence. According to the World Health Organization in 2030, stroke will become the leading cause of mortality.

METHOD: We will present the case of patient M.M. 64 years old, smoker, hypertensive, diabetic, known with a recent right capsulo-thalamic hemorrhagic stroke and left trans-trochanteric femoral fracture operated 6 years ago, rod in the cervix and diaphysis, remaining osteosynthesis material, bilateral gonarthrosis (performed left knee arthoscopy 4 years ago). He was admitted in our department due to persistence of the following complains: left-limb motor deficit, left coxalgia, bilateral gonalgia, right shoulder pain and walking deficit.

RESULTS: At admission BP $=130 / 80 \mathrm{mmHg}, \mathrm{HR}=74 / \mathrm{min}, \mathrm{SO} 2=96 \%$, afebrile, paresis tests $(+)$ left limbs, FMS left limbs 4-/5, left pyramidal hipertony (S. M. Ashworth = 3), clonus $(+)$ left leg, crepitations during mobilization of bilateral knees, limitation of mobility of the left coxo-femoral joint on all movement axes, lower left limb shorter by $4 \mathrm{~cm}$, sensitivity to mobilization / palpation of the left shoulder rotator cuff. Utilizes left plantar orthesis for walking. Biologically occurring: non-specific inflammatory syndrome, hypocalcemia, mild thrombocytopenia. Resting ECG: RS, diffuse ischemia. Coxofemoral radiography was performed which revealed: post-fracture cominutive transthrochanterial left femur state, fixed with a metal rod at the cervix and head level and a rod with screw at the diaphysis level in the position of coxavalga 20 degrees, incomplete present callus, post-fracture dislocation of trochanter and ascension of 4-5 centimeters, signs of coxarthrosis. The patient was proposed for orthopedic reintervention, timed due to recent stroke, with the recommendation to return for continued medical rehabilitation. Thrombocytopenia was considered as drug related and transitory, after repeating the sample was between normal ranges. The rehabilitation program was adapted to the current clinical status of the patient and included: masotherapy, thermotherapy, occupational therapy, kinetotherapy.

CONCLUSION: The case presented is a difficult one in terms of recovery management because it is a patient with two severe, overlapping left sided neurological and osteoarticular pathologies, as well as multiple cardiovascular risk factors. Neurological recovery in the lower limb was performed within minimal parameters because of the risk of fracture. 
P22 - EFFICIENCY OF RECOVERY TREATMENT IN A CASE WITH BROKEN CEREBRAL ARTERY-VENOUS MALFORMATION

\author{
Madalina BORCAN ${ }^{1}$, Ana Maria BUMBEA ${ }^{2}$, Georgeta RADOI ${ }^{3}$, \\ Bogdan Stefan BUMBEA ${ }^{4}$
}

Corresponding author: Madalina BORCAN

${ }^{1}$ Neuropsychiatry Hospital Craiova,

${ }^{2}$ University of Medicine and Pharmacy Craiova,

${ }^{3}$ Delia Med SRL Poiana Mare,

${ }^{4}$ Emergency County Hospital Craiova.

\begin{abstract}

\section{Introduction}

Artery-venous malformations are congenital vascular abnormalities composed of a complex network of arteries and veins connected by fistulas without the interposition of a capillary bed between the arterial source and the venous drainage. Have a frequency of 14 cases / 10,000 individuals, regardless of gender and $6 \%$ of brain injuries.
\end{abstract}

\title{
Material and method
}

We present you a case of a 70-year-old patient, known with high blood pressure, whose symptomatology suddenly started with intense headache followed immediately by nausea and vomiting followed by alteration of conscious. The patient was admitted to the intensive care clinic of the Craiova County Emergency Hospital for a period of 3 weeks. As a result of investigations imaging (CT, MRI angiography) to show an artery-venous malformation voluminous location of the temporal-occipital right, flood all four ventricles, moderately dilated ventricles, shifted to the left of the median line, the collapse partial the lateral ventricle as a secondary effect of the whole mass of artery-venous malformation existence. At the time of the physical examination in our clinic we discovered the hemi-body motor deficit as well as brachial prevailing left lower limb. Standing and walking were not possible. Tendon reflexes do not occur in the lower limbs bilateral Babinski reflex present bilaterally. During hospitalization received medical treatment with neurotrophic effect and hypotensive, with rehabilitation treatment that consisted of massage, physiotherapy and occupational therapy.

\section{Results and discussions.}

We obtained the remission of the left lower limb deficiency and ameliorating the deficit from the right hemibody. With occupational therapy, we have improved the functional performance in the right hand.

\section{Conclusions.}

Uncontrolled therapeutically or unpredicted malformations in a timely manner may be disastrous. Rehabilitation therapy applied as early as possible prevents the installation of severe deficits and leads to improved functionality and also the quality of life.

Key words: artery-venous malformation, rehabilitation, 
P23 - Is possible the management of synovial chondromatosis of the hip by arthroscopy or complex balneal treatment?

\author{
Demirgian Sibel ${ }^{1}$, Nan Simona ${ }^{2}$, Lulea Adela ${ }^{3}$, Lascu Ioana ${ }^{4}$ Marin Viorica ${ }^{5}$
}

Corresponding author: Demirgian Sibel, E-mail: sibeldemirgian@yahoo.com,

${ }^{3}$ Balneal and Rehabilitation Sanatorium Techirghiol

\title{
Abstract
}

\section{Introduction}

INTRODUCTION: Synovial chondromatosis (SC) is a disease commonly affecting large joints including knee, hip, and shoulder. Although the condition has been described as a benign neoplasm of the synovium, its progressive dissemination into the articular structures will result in joint destruction. The etiology of SC is not clearly known yet; nevertheless, metaplasia of synovial lining tissue into chondrocytes has been explained as a probable cause. ${ }^{1,2}$ It usually affects a single joint in which the most common site is the knee and is twice as frequent in men as in women. It is commonly seen during the third to fifth decades of life presenting with aggravating joint pain, swelling, crepitus, and limited range of motion (ROM).

MATERIALS \& METHODS: The coxo-femoral joint is a complex, strong joint, supporting the entire body weight, with an important role in static and locomotion. We present a 37 years old female patient without any underlying disease, from the urban area, who presented in our clinic for mechanical pain accompanied by functional impotence at the left coxofemoral joint level (VAS =9). From the history of the pacient we find that the current pain started 3 years ago, after an intense physical effort(running). She underwent physiotherapeutic procedures (ultrasound, lasertherapy and electromagnetic fields) with slight pain relief. After many specialist consultation, in rheumatology, rehabilitation therapy and orthopedics, also paraclinical investigation(blood tests, radiographys, IRM's) for the persistent pain with mechanical character in the left hip and after three years of evolution of the disease, she receives the diagnosis of hip chondromatosis Hip radiographs showed a lot of calcified loose bodies in the medial inferior part of the hip. Magnetic resonance imaging showed femuroacetabular impingment, intraarticular liquid, proliferation of the synovium within the joint space, intra-articular loose bodies, osteophyte of femoral head. She was initially treated with nonsteroidal anti-inflammatory drugs, but this did not relieve the pain. Because of the increased pain, the patient underwent arthroscopic debridement and partial resection of hypertrophic synovium and removal of loose bodies in the left hip with a relief of pain for limited period of time.

After few months she started a complex balneophysicalkinetic treatment which consists in mud application, electrotherapy, masotherapy and kinetotherapy with the objectives: muscle relaxation, fighting pain and inflammation, increased muscle tone, posture correction and body alignment.

RESULTS: In this case we must consider the progressive evolution of hip pain, which initially seems to be caused by hip arthritis. Subsequently, by the persistence of the algic symptomatology and the clinical and paraclinical investigations, the diagnosis proved to be hip chondromatosis having as a therapeutic alternative first AINS drugs, after the hip arthroscopy with synoviectomy, extraction of free bodies, debridement and joint lavage, to which was added later the complex rehabilitation treatment, the evolution being favorable for short period of time.

CONCLUSIONS: SC or osteochondromatosis (when ossification is present), also called Reichel's syndrome, was first described by Reichel in $1900 .^{3}$ The etiology of this disorder is still unclear. Many theories such as reactivation of residual embryonal cells, traumatic initiation, or benign neoplastic disease have been advocated. ${ }^{4}$.A hip arthroscopy has some advantages over a traditional hip replacement surgery and was considered the best therapeutic option in our case but the results were limited in time. In our case any of treatments we used have good results to relief pain(medication, arthoscopy, complex balneal treatment) in order to prevent the artroplasty at a young age(in our case 37 years). In this case, cause of the persistent pain and other symptoms who developed for over 3 years, we highly recommend the total hip replacement with the possibility to change when is necessary because our patient need a normal life for her age. 


\title{
P24 - The Efficiency of Medical Treatment of Scoliosis - Paediatrics
}

Mădălina Codruța Verenca ${ }^{1,2}$, Sorina Mierlan², Claudiu Elisei Tanase ${ }^{2}$

Corresponding author: Claudiu Elisei Tănase, E-mail: tanaseclaudiumd@gmail.com,

1 SL dr., Clinical Emergency Hospital for Children "Sf.Ioan", Department Rehabilitation, Galati, Romania 2 "Dunarea de Jos" University, Galati, Romania

\begin{abstract}
Introduction: Scoliosis represents deformation of vertebral spine that can be noticed through a lateral curve in a frontal plan and a vertebral rotation towards the spine concavity. If the rotation of vertebrae occurs in thoracic region, then the entire thoracic box is affected. Convexity is the factor that gives the name of the affliction. The purpose of the study consists in identifying the factors that are influencing the efficiency of scoliosis treatment through the analysis of some essential criteria, respectively the moment the patient is first seen by a doctor, the right treatment for each particular case and the evolution of the patient under the treatment, especially those that present a Cobb angle higher than 10 degrees at the beginning of the treatment and during.

Methods: The study was an analytic and statistic one that followed the evolution of patients under treatment during 2018. We included 78 patients that have presented for clinic functional evaluation and specialized treatment, at Sectia de Recuperare Medicina Fizica si Balneologie a Spitalului Clinic de Urgenta pentru Copii "Sf. Ioan" Galati, during 2018.

Results: The data that we procured as a result of the study, proved that most patients under treatment belong to the feminine gender and most of them are 10-20 years old. Only a third of the cases under evaluation had Cobb angle under 10 degrees at the beginning of the treatment.

Conclusion: As a result of the study we conducted we could prove the importance of the connection that exists between choosing the right treatment for your patient and the level of involvement of the patient towards the goal which is getting better. Analysing the results we could observe that even though we have at our disposal an efficient way to treat the patient, this is not enough, because it is a treatment that requires a certain level of commitment from the patient which, in most cases, it does not exist.
\end{abstract}

Key words: scoliosis, Cobb angle, vertebral spine, 


\title{
P25 - Orthopaedic manifestations of Neurofibromatosis type 1 - case report
}

\author{
Florentina NASTASE ${ }^{1}$, Alin Laurentiu TATU ${ }^{2}$, Madalina Codruta VERENCA ${ }^{1}$ \\ Florentina NASTASE', Alin Laurentiu TATU², Madalina Codruta VERENCA
}

Corresponding author: Florentina NASTASE, E-mail: florentina34ro@yahoo.com

${ }^{1}$ Clinical Hospital for Children "Sf. Ioan", 2 Gheorghe Asachi Street, Galati, Romania

2"Dunarea de Jos" University of Galati, Faculty of Medicine and Pharmacy, 47 Domneasca Street, Galati, Romania

\begin{abstract}
Introduction.

Neurofibromatosis type 1 (NF 1) or is one of the most common autosomal dominant genetic diseases. It is characterized by "café-au-lait" spots and multiple tumors starting from central and peripheric nervous system. The diagnosis is determined on two out of seven criteria: 1. Six or more light brown spots larger than $5 \mathrm{~mm}$ diameter - pre-puberty or $15 \mathrm{~mm}$ diameter - post-puberty; 2. Two or more neurofibromas or one plexiform neurofibroma; 3. Axillary or inguinal freckling; 4. Optic glioma; 5. Two or more Lisch nodules; 6. Bone injuries: tibia pseudarthrosis or dysplasia of sphenoid wing; 7. A relative of first degree having NF 1 diagnosis.
\end{abstract}

\section{Materials and method.}

We present the case S.S., male, 16 years old, comes to our medical unit in for evaluation and recovery treatment. AHC: mother and two maternal uncles, with skin markers of NF 1, without any other symptoms, who consider themselves to be healthy; 12 years old brother with NF 1, a 7 years old sister with light brown spots. APP: congenital pseudarthrosis for both bones left shank - operated. Clinical: spinal deviation dorsalright, lumbar- left; multiple light brown spots, axillary freckling; unequal legs, left shank- $5 \mathrm{~cm}$ shorter.

\section{Results and discussions.}

The particularity of the case is the typical form of disease, that associate common complications: Scoliosis, Macrocefalitis, Dislalitis, Mental retard, Chest deformities, bone injuries: congenital pseudarthrosis of tibia.

\section{Conclusions.}

Approximately $50 \%$ of pacients have signifiant musculoskeletal manifestation, with scoliosis and congenital pseudarthrosis of tibia most common. Management of the orthopaedic manifestations of NF 1 is often difficult. Because NF 1 affects multiple organ systems, patients are likely to benefit most from a multidisciplinary treatment strategy.

Key words: orthopaedic manifestation, Neurofibromatosis type 1, "café-au-lait" spots, 
P26 - The attenuation of energy metabolic misbalance by means of aerobic, hypoxic, hypothermal adaptation and environment optimization at recreation resort center

Simona CARNICIU', Anatolie BACIU ${ }^{2,3}$, Vasile FEDAS ${ }^{2}$

Corresponding author: Anatolie Baciu, E-mail: anatolikbacio@gmail.com

1. "Prof Dr NC Paulescu National Institute of Diabetes, Nutrition and Metabolic Diseases", Bucharest, Romania

2. "Institute of Physiology and Sanocreatology", Kishinev, Republic of Moldova

\section{Abstract}

Introduction. Adaptive response induced by hypoxia includes down-regulation of energy demand for prolonging cellular survival. Hypoxia influence is characterized by up-regulations of glycolytic enzymes activity and glucose consumption. Moderate hypoxia permits neuron maintenance ATP production degree on the background of increased glycolytic flux. Vascular and metabolic response to hypoxia (hypoxemia) is mediated by hypoxia inducible factor (HIF). HIF plays key role in mediating of the expression of vascular endothelial growth factor (VEGF), glucose transporter (GLUT 1), and glycolytic enzymes. In organs and tissues of diabetic patients oxygen insufficiency was manifested. One successful modality to improve hypoxic state in diabetic patients could be application of intermittent hypoxia in combination with aerobic training. Adaptation to hypoxia leads to increased oxygen saturation during resting period by means of the facilitation of ventilation function and chemoreflexes, and reduced sympathetic tone associated with hypoxia. So-called cryotherapy (hypothermal training) in the active population is often based on the immersion in cold water $\left(22-15-9^{\circ} \mathrm{C}\right)$. Reducing of the metabolic rate during cold water expose and metabolic rate acceleration in rest period could be induced by the immersion and exercising in cold water. Thus, the immersion in cold water leads to metabolic rate elevation.

Material and method. The investigation was carried out in voluntary sport students (men ages 19 to $21 \mathrm{YO}, \mathrm{n}=20$ ) and in the laboratory animal (male rats) exercised by swimming and treadmill running. The Recreation Program consists of aerobic exercise ( 5 weeks) intensity (75-80 \% of $\mathrm{VO}_{2} \mathrm{max}$ ), frequency (3-5 session/week) and duration of sessions (30$90 \mathrm{~min}$ ) were individualized with reference to deviation of blood glucose, lactate, lipoproteins, urine urea levels, $\mathrm{SpO}_{2}$ test, and subjective sensations. To simulate altitude hypobaric environment laboratory animals $(n=5)$ were adapted to hypoxic hypoxia at the height of 3,000 m under hypobaric chamber conditions before the main experiment. The Program was performed with daily 5-hour exposure from 2:00 P.M. to 7:00 P.M. The elevating to the altitude was carried out step by step with $5-10-15$-minutes stations at heights of 1,$000 ; 2,000 ; 3,000 \mathrm{~m}$. The exposure at the $3,000 \mathrm{~m}$ was subsequently prolongated during first 15 -day time period (from $5 \mathrm{~min}$ to 5 hours). Neuronal morphometric indices and HIF-1-alpha immunoreactivity were estimated in the rat brain: lateral hypothalamic area (LH) and ventral tegmental area (VTA) for evaluation of activating (food intake) and reward (pleasure) systems equilibrium.

Results and discussions. It was revealed that peripheral blood oxygen saturation $\left(\mathrm{SpO}_{2}\right)$ measured at the resting state was elevated after The Recreation Program performing (from 93,1 $\pm 0,6$ up to 97,9 $\pm 0,2 \%, \mathrm{P}<0,05$ ) in comparison with pre-adaptation period. Peripheral blood aerobic properties improvement was observed. The degree of blood glucose falling down during exercise session was reduced after adaptation in comparison with first session. Adaptive aerobic exercise is associated with authentic increase of high-density lipoproteins concentration on the background of lowdensity lipoproteins decrease. The ratio of adipose and muscle tissue was deviated to muscle tissue predomination after training program. The percentage of HIF-1-alpha immuno-positive neurons was increased in LH and VTA in animals adapted to aerobic and hypoxic training. Orexinergic LH activating system and dopaminergic VTA reward system are implicated in neuroendocrinological complex and delicate mechanism of metabolic balancing and represent accepter centers for neural and humoral stimuli.

Conclusions. Individualized Recreation Program provides neuroplasticity changes in activating and reward systems by balancing of energy and plastic metabolism. This applied physiological and physical medical technology is planned for utilization in Laboratory conditions, Resort and Recreation Centers. It is preferred application of proposed personalized program at Recreation and Resort Centre situated in Natural Mountain Lake, River reservoir areas for procuring "PersonNatural Environment" communication.

Key words: intermittent hypoxia, aerobic exercise, aquatic hypothermal training, environment optimization, 
P27 - Complex clinical and therapeutic rehabilitation approach of a patient with

Complete AIS/Frankel A quadriplegia post cervical spinal cord injury after accidental fall off a trailer and multiple complications occurring during disease progression - case study 


\section{P28 - Molecular treatment strategies in osteoporosis}

\section{Ana-Maria Pelin ${ }^{1}$, Monica Georgescu ${ }^{2}$, Cristina Stefanescu ${ }^{1}$, Costinela Georgescu ${ }^{1}$}

Corresponding author: Ana-Maria Pelin, E-mail: anapelin@gmail.com

\section{Abstract}

\section{Rationale of the study:}

Osteoporosis is an increasingly occurring disease in the last years, due to population's aging. The disease fragilizes bones and exposes people to an increased fracture hazard. Osteoporosis develops slowly, over many years, most often asymptomatic and undiagnosed, until a fragility fracture occurs.

Material and method: The purpose of this paper is to present the sequential therapies used in the treatment of osteoporosis, according to the new practical guidelines, and to present the newly entered molecules in the therapeutic practice (monoclonal antibodies).

Material and method: Various specialized e-platforms have been searched (PubMed, Scopus, Web of Science), as well as forums specializing in the treatment of osteoporosis, American Association of Clinical Endocrinologists (AACE/ACE), National Osteoporosis Foundation (NOF) ACR (American College of Rheumatology) and ISCD (International Society for Clinical Densitometry) and the new osteoporosis treatment guidelines have been analysed.

Results: The therapeutic agents used in the treatment of osteoporosis have antiresorptive action or osteoforming action. The studies performed until present did not show the superiority of associating the two types of medication as compared to each and every medication considered separately. When bisphosphonates are contraindicated, there is intolerance or the obtained results are minimum, human, anti-RANKL (denosumab) monoclonal antibodies may be administered, which inactivate the osteoclasts and their development. The hormone replacement therapy, similarly to the selective estrogen receptor modulators (raloxifene), has very limited indications due to the severe adverse reactions (thromboembolism, endometrium cancer, breast cancer, cardiovascular diseases). Other new molecules, such as the Cathepsin K inhibitors or the antisclerostin antibodies are still under study.

\section{Conclusions:}

There are specific drugs used in the treatment of osteoporosis: bisphosphonates, denosumab, parathyroid hormone, hormone therapy and selective estrogen receptor modulators, each having specific indications, adverse reactions and contraindications.

Key words: osteoporosis, monoclonal antibodies, fracture, sequential therapy, 


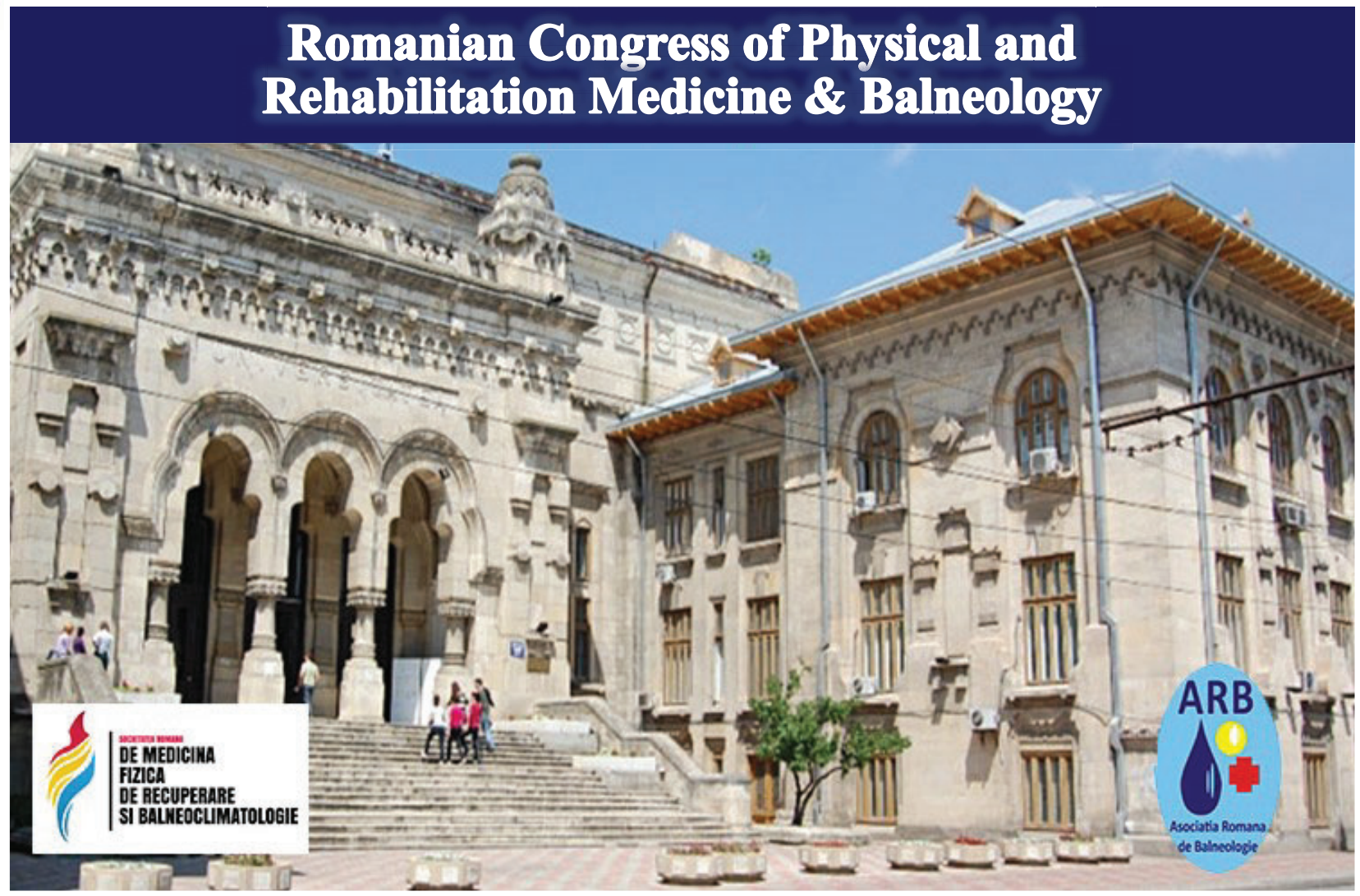

03-06 September 2019, Galați

\section{Organizing Partners / Sponsors}

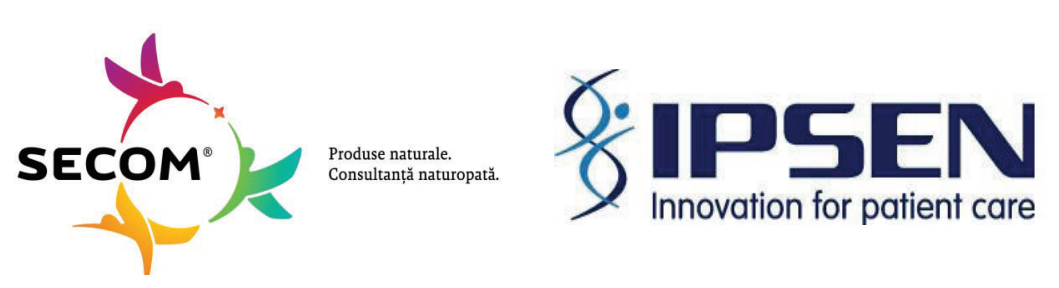

\section{6. \\ BORSEC}

TRADIȚIE SI PRESTIGIU
PHYSIOMED

(P) TEARMA

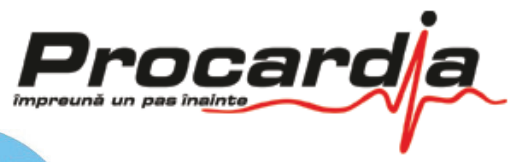

ALFASIGMA
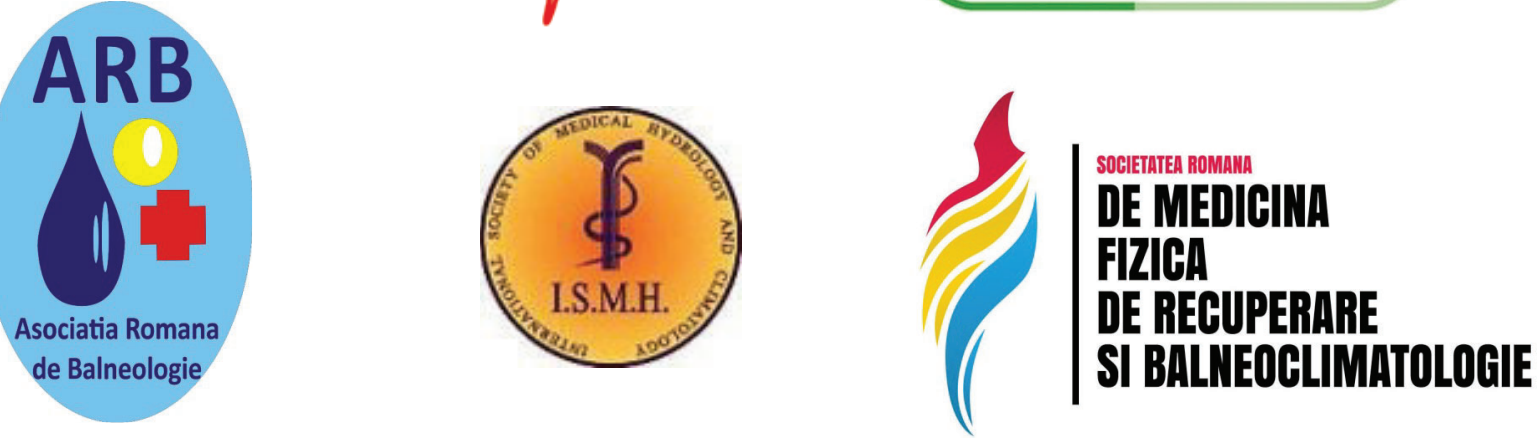


\section{Bors

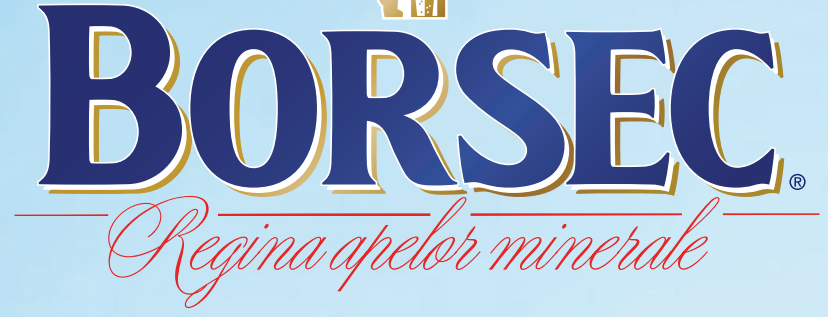

\section{Apa minerală naturală poate salva vieți}

Noile cercetări în domeniul dietoterapiei arată că un consum constant de apă minerală naturală carbogazoasă cu 0 anumită compoziție poate ajuta la menținerea sănătății sistemului digestiv, a inimii, poate reduce riscul de moarte prematură din cauze cardiovasculare și sindrom metabolic.

S-a constatat că ionii bicarbonat alcalini, ce pot neutraliza acizii, au un impact pozitiv asupra nivelului de lipoproteine. Există, de asemenea, dovezi experimentale că bicarbonații pot îmbunătăți funcționarea colecistului și metabolismul colesterolului.

În 2012, s-a efectuat un studiu la Institutul Național de Recuperare, Medicină Fizică și Balneoclimatologie, care a avut ca obiectiv principal identificarea și evidențierea beneficiilor asupra pacienților cu sindrom metabolic, prin consumul de apă minerală carbogazoasă Borsec, ca 0 soluție complementară, adjuvantă la mijloacele de vindecare existente. În urma studiului pe subiecții care au ingerat 2 I/zi de apă carbogazoasă Borsec, timp de o lună, $s$-a ajuns la următoarele concluzii:

- Tendința importantă de scădere a glicemiei, colesterolului total și LDL-colesterolului;
- Nivelul seric al acidului uric a fost în scădere semnificativă;

- A crescut sensibilitatea la insulină;

- 0 serie de markeri ai inflamației și-au redus valorile.

Așadar, veștile sunt foarte bune, apa minerală carbogazoasă din sursa Borsec prezintă interes în scăderea riscului cardiovascular la pacienții cu sindrom metabolic. Ingestia acestei ape de către subiecți hipertensivi, diabetici, dislipidemici și cu obezitate de tip abdominal poate duce la scăderea glucozei serice, creșterea sensibilității la insulină, scăderea nivelului seric de colesterol total și LDL colesterol, precum și al acidului uric. Éfectul de protejare a vaselor de sânge și cel antiinflamator sunt demonstrate de scăderea nivelului markerilor sindromului proinflamator.

În acest sens, Borsec, apa minerală naturală, bicarbonată și magneziană propune persoanelor active, dar și celor cu o serie de afecțiuni din sfera metabolică și cardiovasculară, o soluție adecvată pentru hidratarea corectă și un mijloc adjuvat în tratamentul sindromului metabolic.

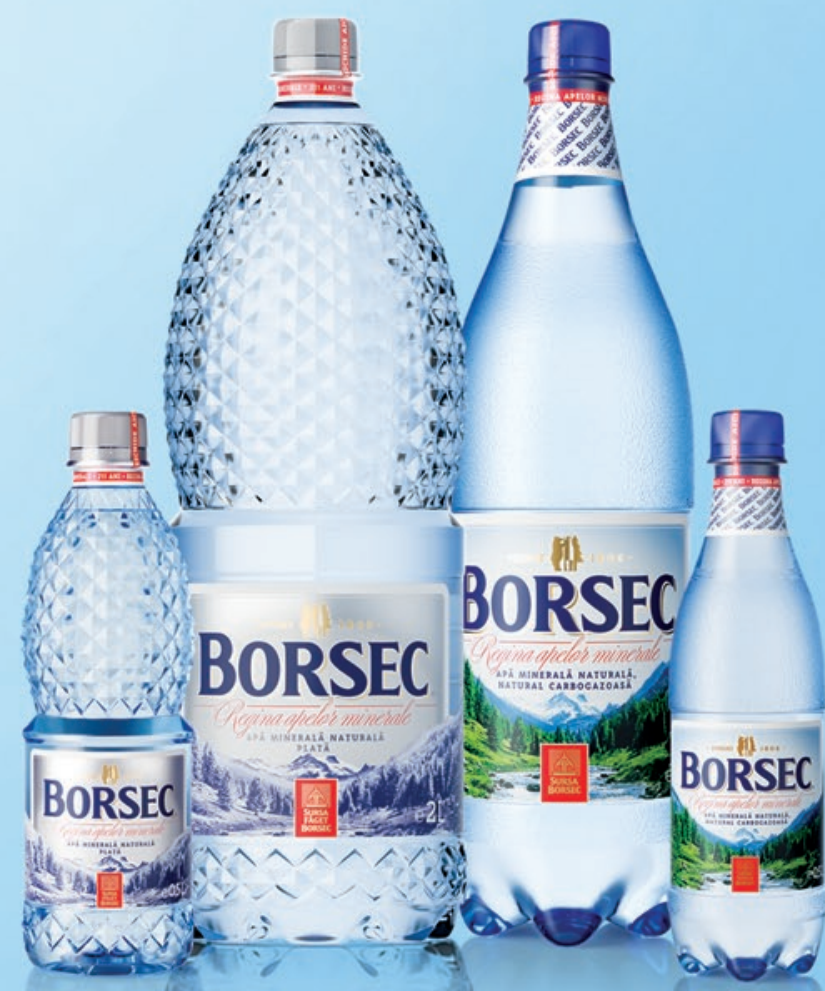




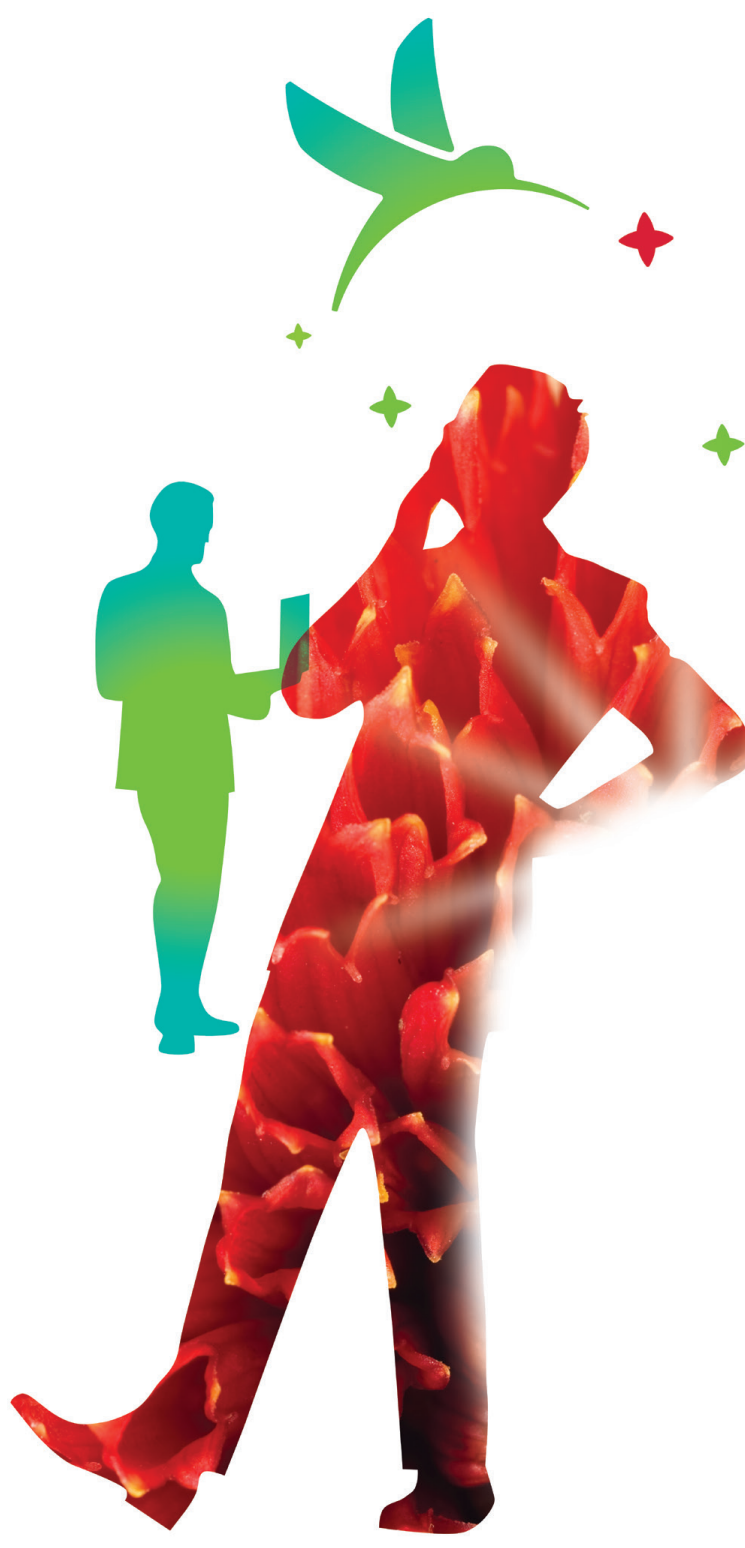

Neuro Optimizer ${ }^{\circledast}$ Siguranță și eficiență în terapia și profilaxia tulburărilor neurologice

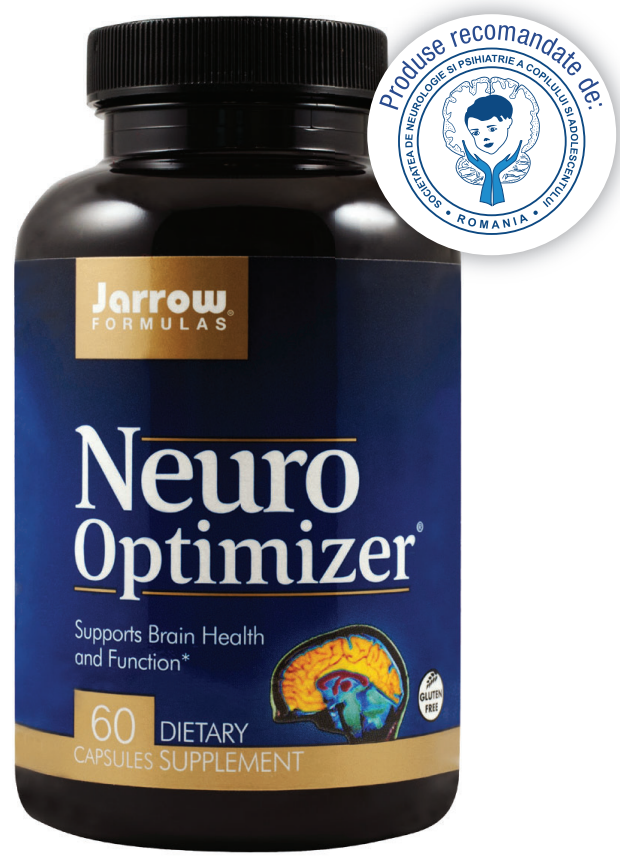

Formulă complexă pentru:

○ neuroprotecție și suport în procesele neurodegenerative și în recuperarea neuromotorie

○ îmbunătățirea stării emoționale

$\checkmark$ perioadele de suprasolicitare și efort intelectual

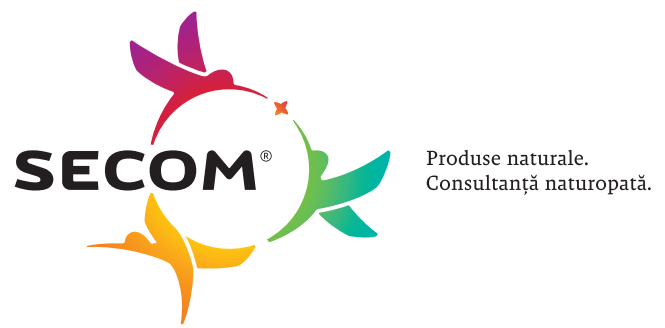




\section{$\approx$ Dysport}

COMPLEX HEMAGLUTIN-TOXINĂ BOTULINICĂ TIP A

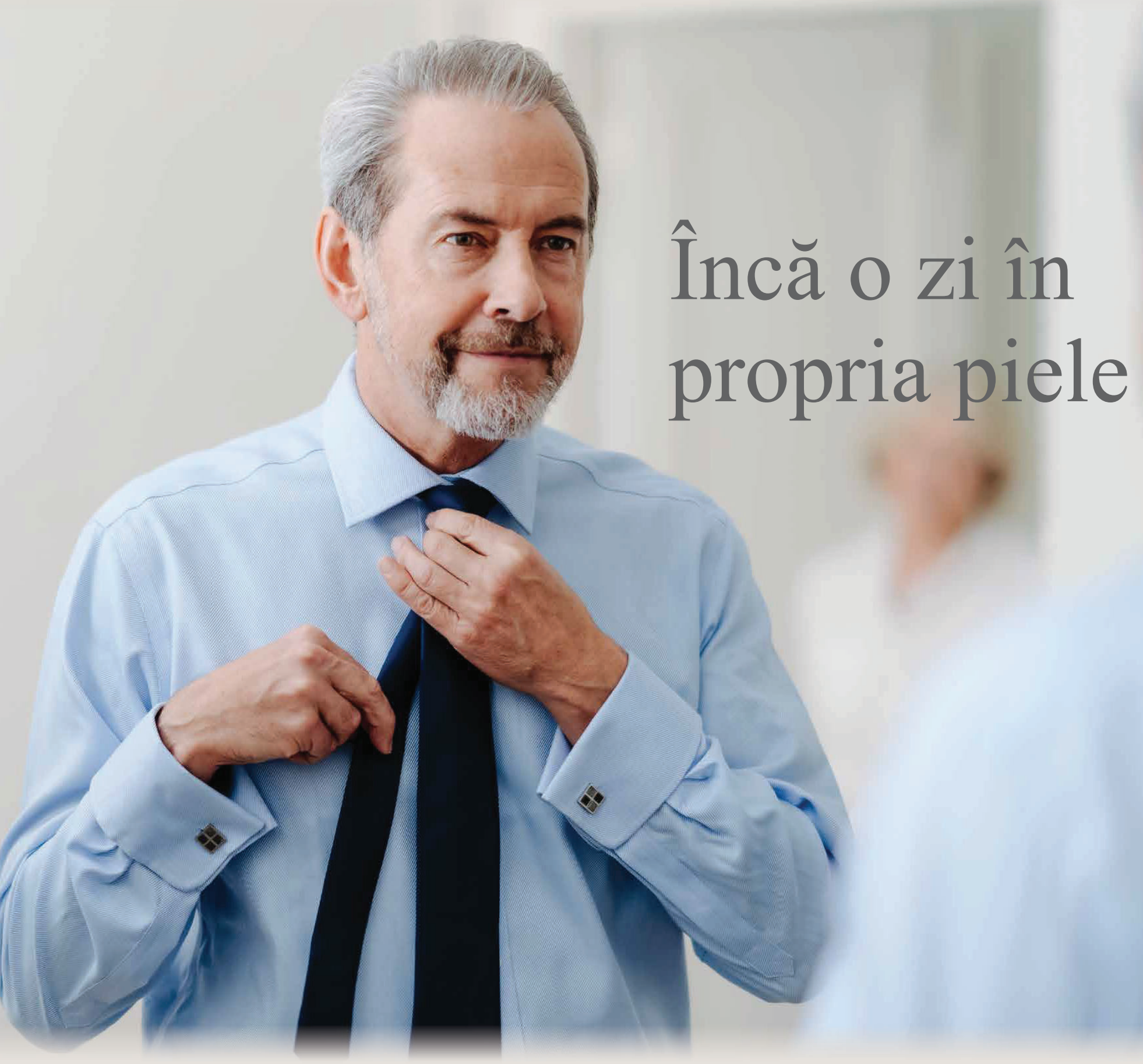

Pentru pacienții care suferă de spasticitate,

beneficiile tratamentelor pot dispărea cu câteva săptămâni înainte de reinjectare ${ }^{1}$

Dysport $^{\circledR}$ are o durată a răspunsului de cel puțin 12-16 săptămâni²

Dysport ${ }^{\mathbb{}}$ le oferă pacienților o ameliorare de durată a simptomelor și o șansă de a se simți confortabil cu cu ei înșişi în intervalul dintre injectări ${ }^{3}$ 


\section{SOLUTII TEHNOLOGICE NOUTATI DE ULTIMA ECHIPA DEDICATA INOVATOARE DE CEA MAI INALTA CALITATE \\ ORA IN TERAPIA \\ RECUPERATORIE \\ NEVOILOR CLIENTILOR \\ PRIN SUPORT CONSTANT}

\section{PHYSIOMED ${ }^{\circledR}$}

\section{TECHNOLOGY FOR THERAPY}
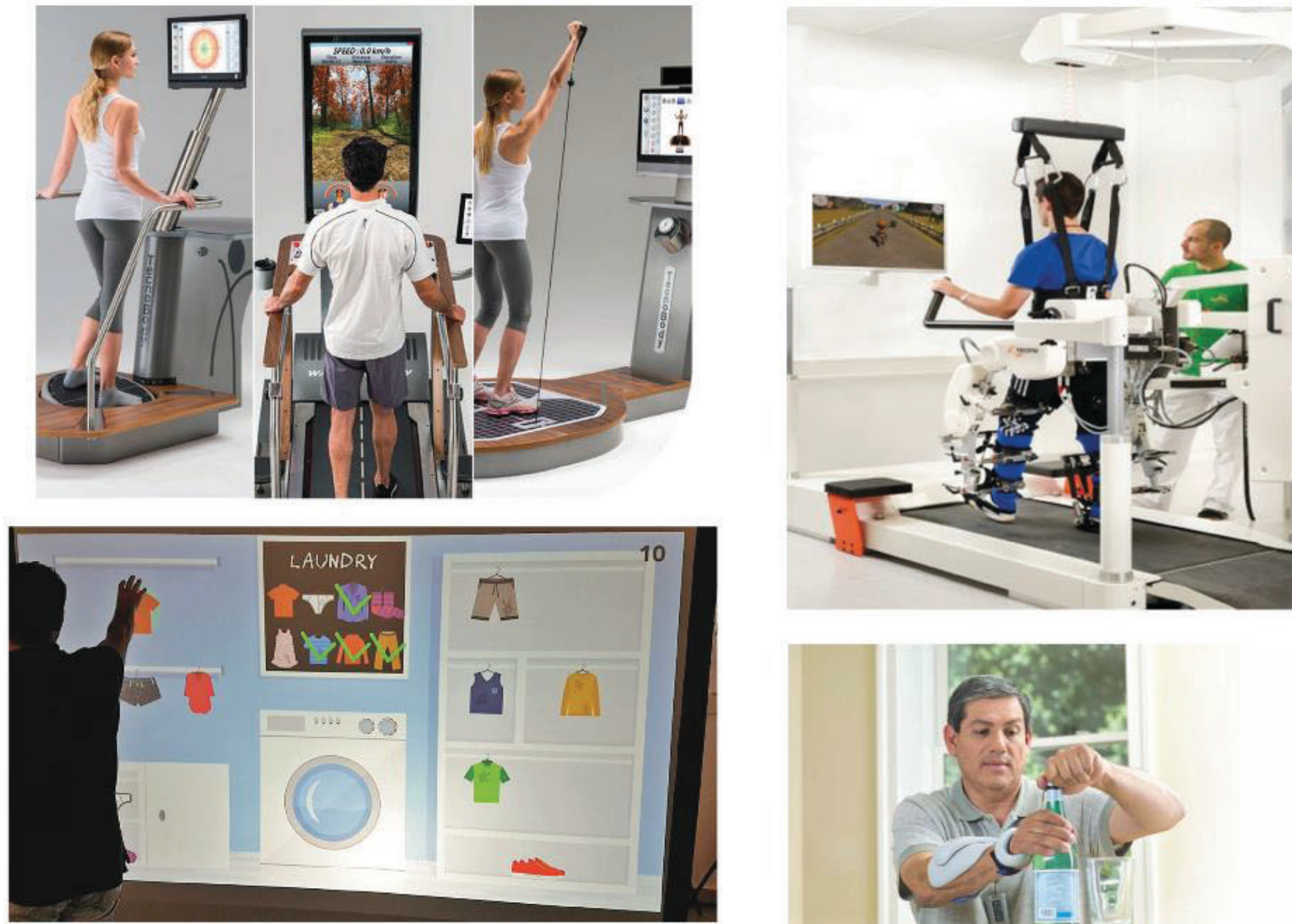

Recuperare Robotica, Analiza de Miscare,

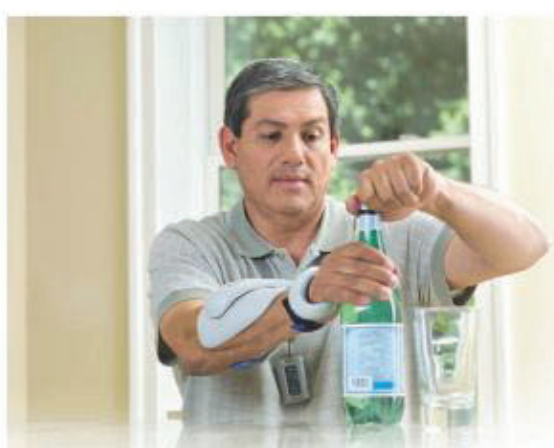

Evaluare si Recuperarea Echilibrului Static si

Dinamic, Recuperare utilizand Realitatea Virtuala, Stimulare Electrica Functionala, Gimnastica Medicala Computerizata, Terapia Deep Oscillation, CARE Therapy 


\section{Stinge durerea neuropată!}

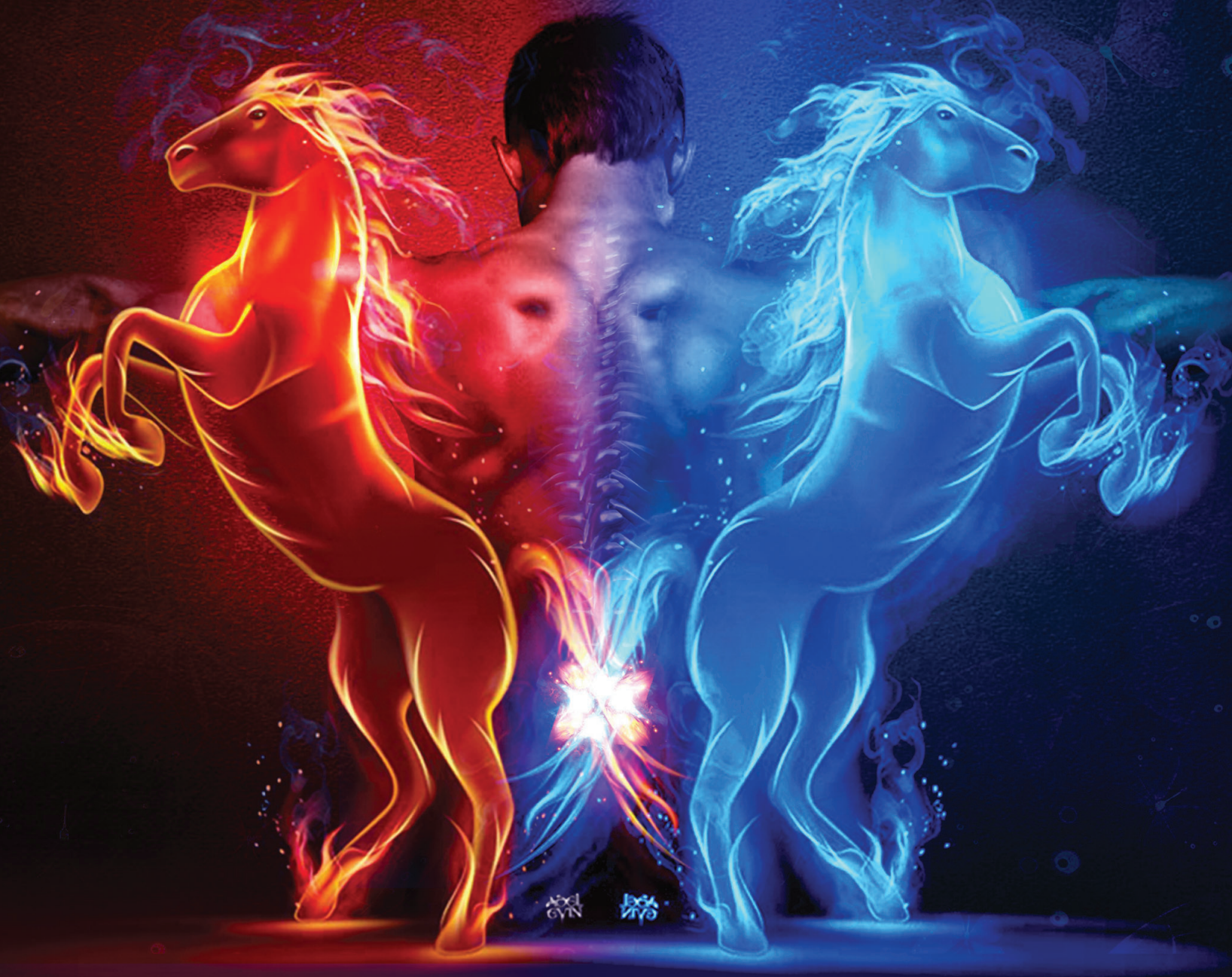

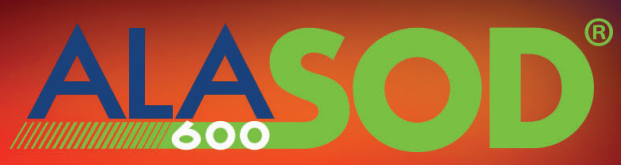

DURGRE ACUTÁ

$10 / 2 \mathrm{i}$

4 săptămâni

\section{ALAnerv $^{\circ}$}

DURERG CRONICĂ

$10 / 2 i$

6-8 săptŏmâni

Acest material promoțional este destinat profesioniștilor din domeniul sănătății. ALA 600-SOD și ALAnerv sunt suplimente alimentare. Citiți cu atenție prospectul și informațiile de pe ambalaj. Profesioniștii din domeniul sănătății sunt rugați să raporteze orice reacție adversă suspectată la aceste produse la adresa de e-mail: drugsafety.ro@alfasigma.com. 


\section{()PHARMA
TELNET}

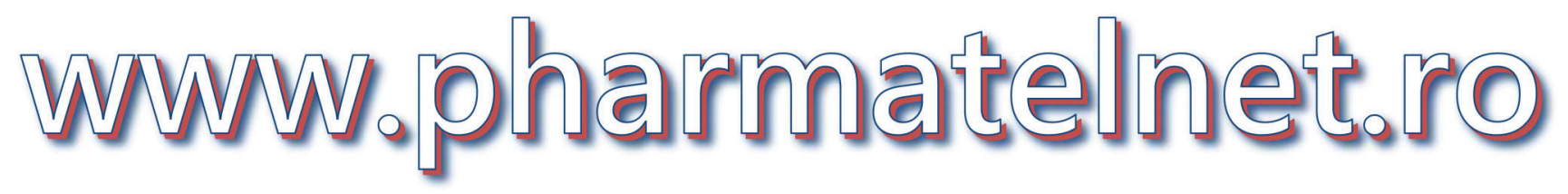

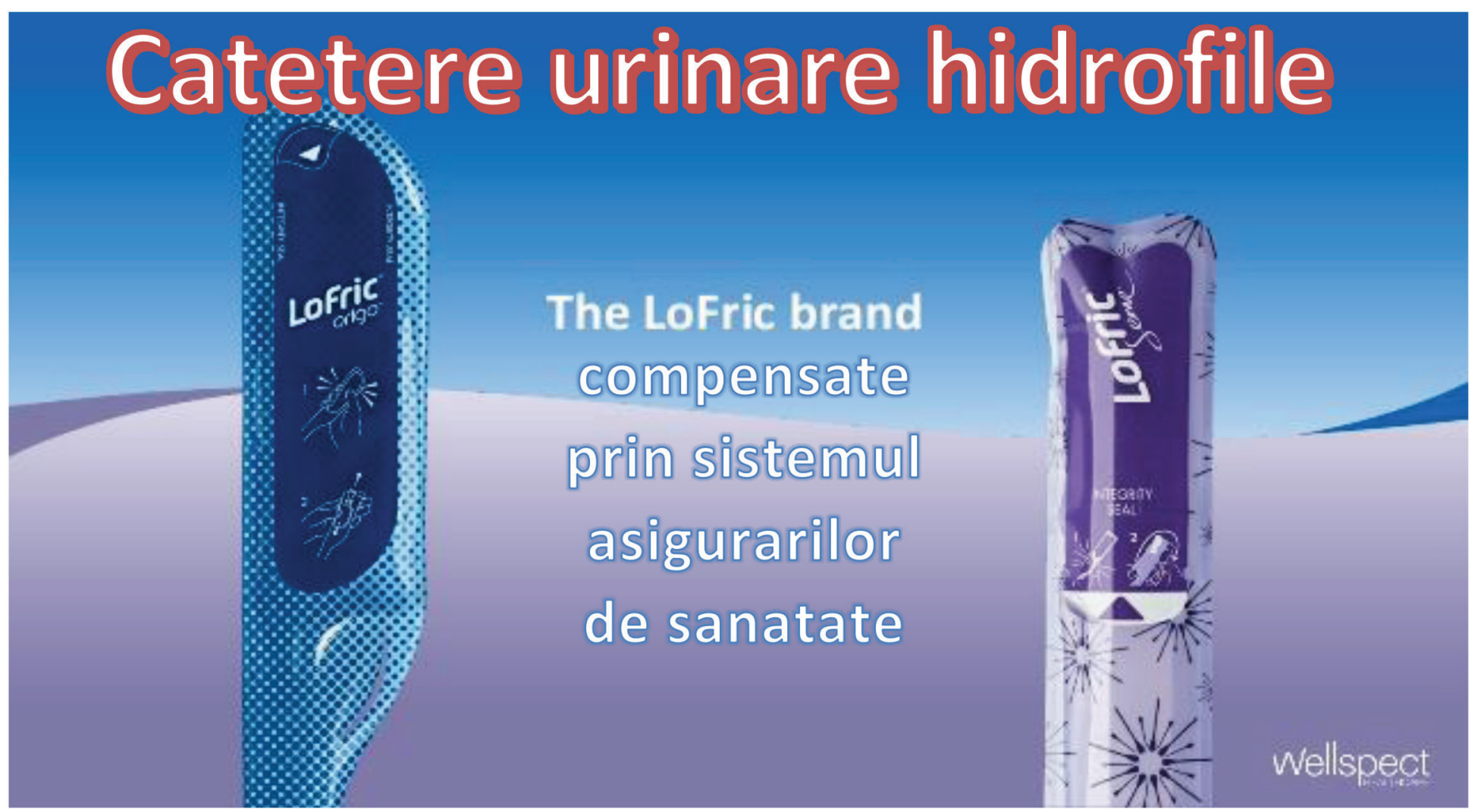

PolyMeri

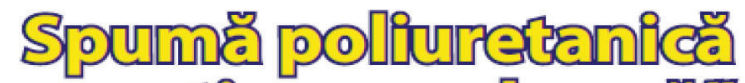

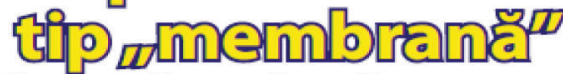

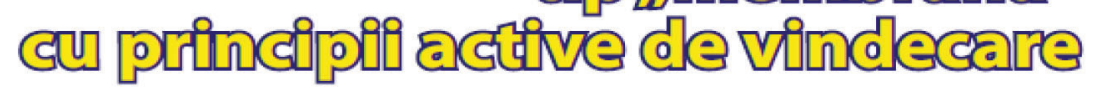

\section{PLÄGI GRONICE}

Indicatii: $\rightarrow$ Escare (I-IV)

$\rightarrow$ Ulcere diabetice

$\rightarrow$ Plagi cu cavitati

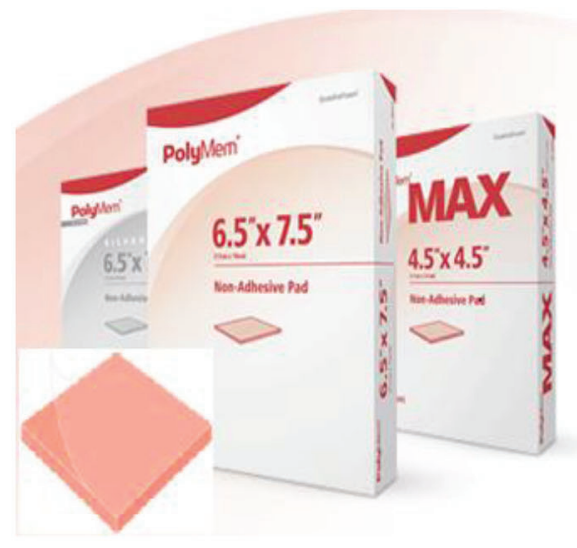


Bg
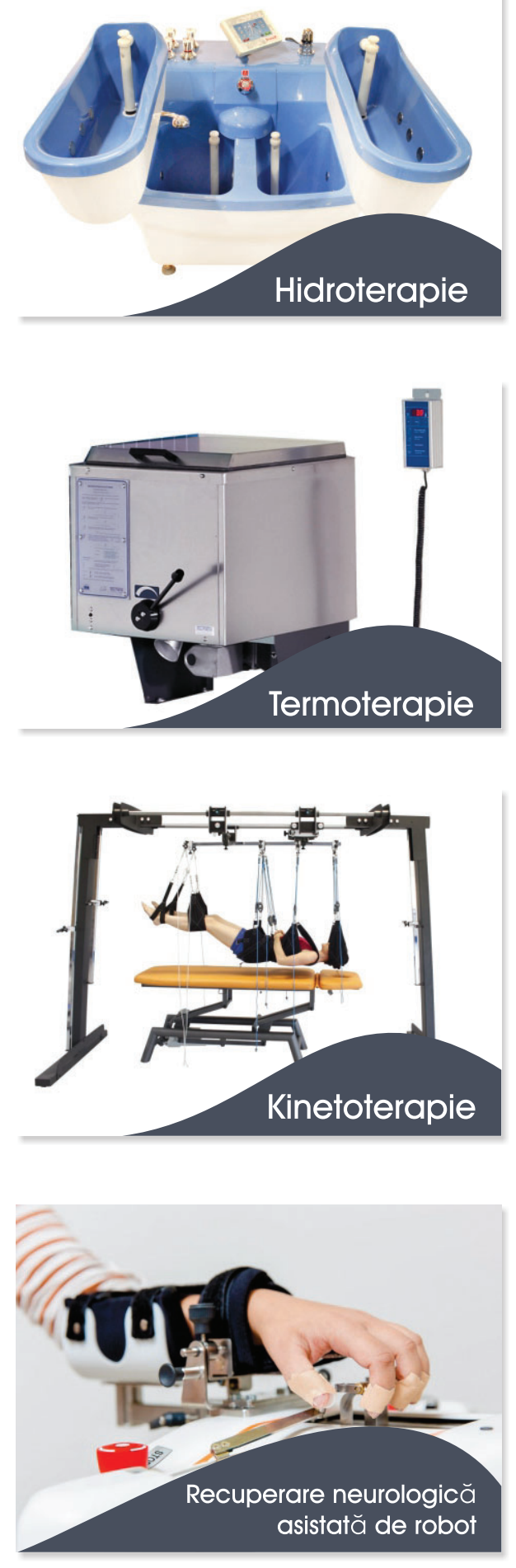

\section{de 27 de ani}

\section{dezvoltăm}

\section{recuperarea şi}

balneoclimatologia

românească
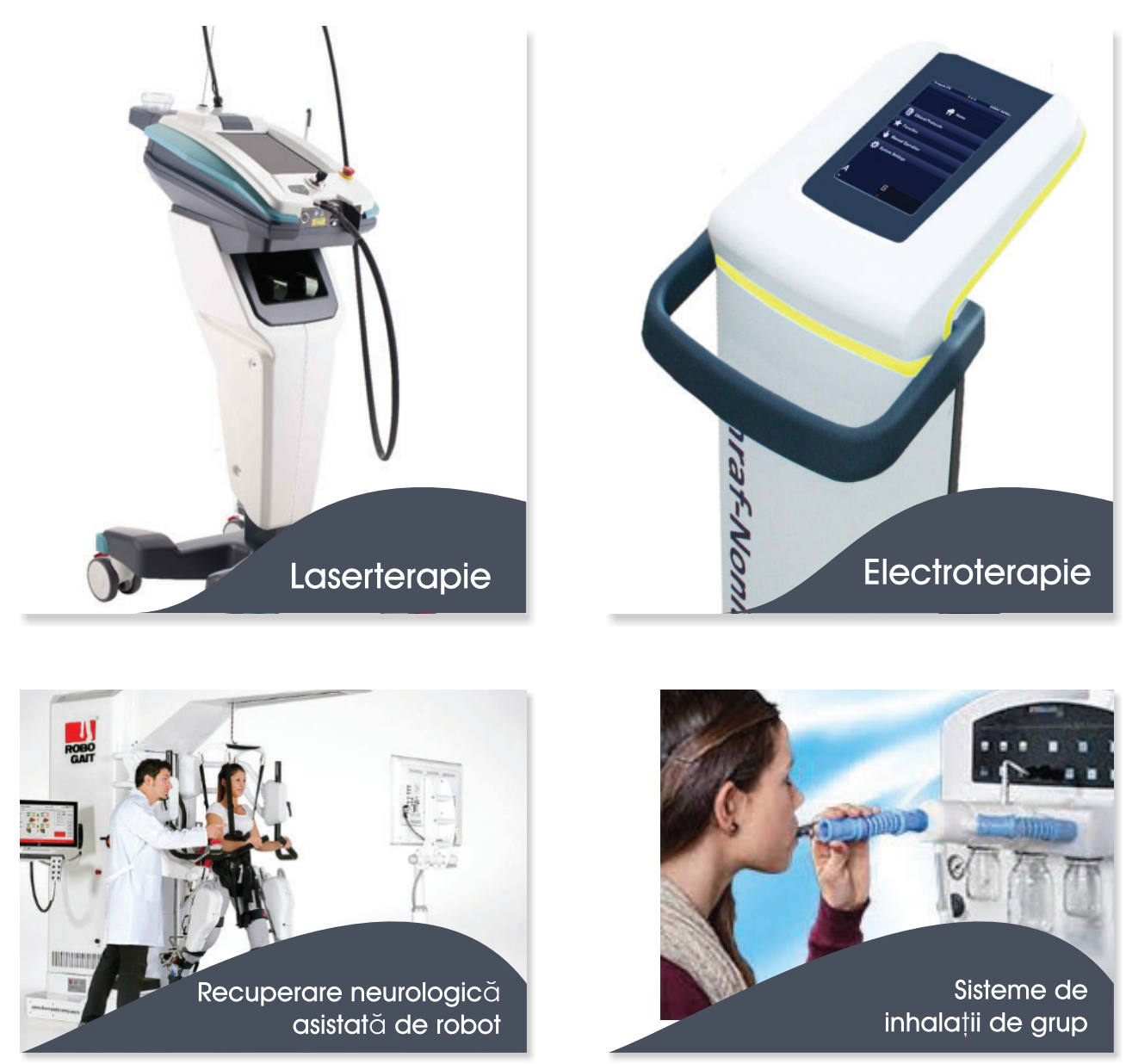

童TH

IS bama

SCHUMACHER

$-A=7$

TRAUTWEIN

tyromotion 


\section{IMESOL}

Etoricoxib $30 \mathrm{mg}, 60 \mathrm{mg}, 90 \mathrm{mg}, 120 \mathrm{mg}$

\section{Redă bucuria mișcării!}

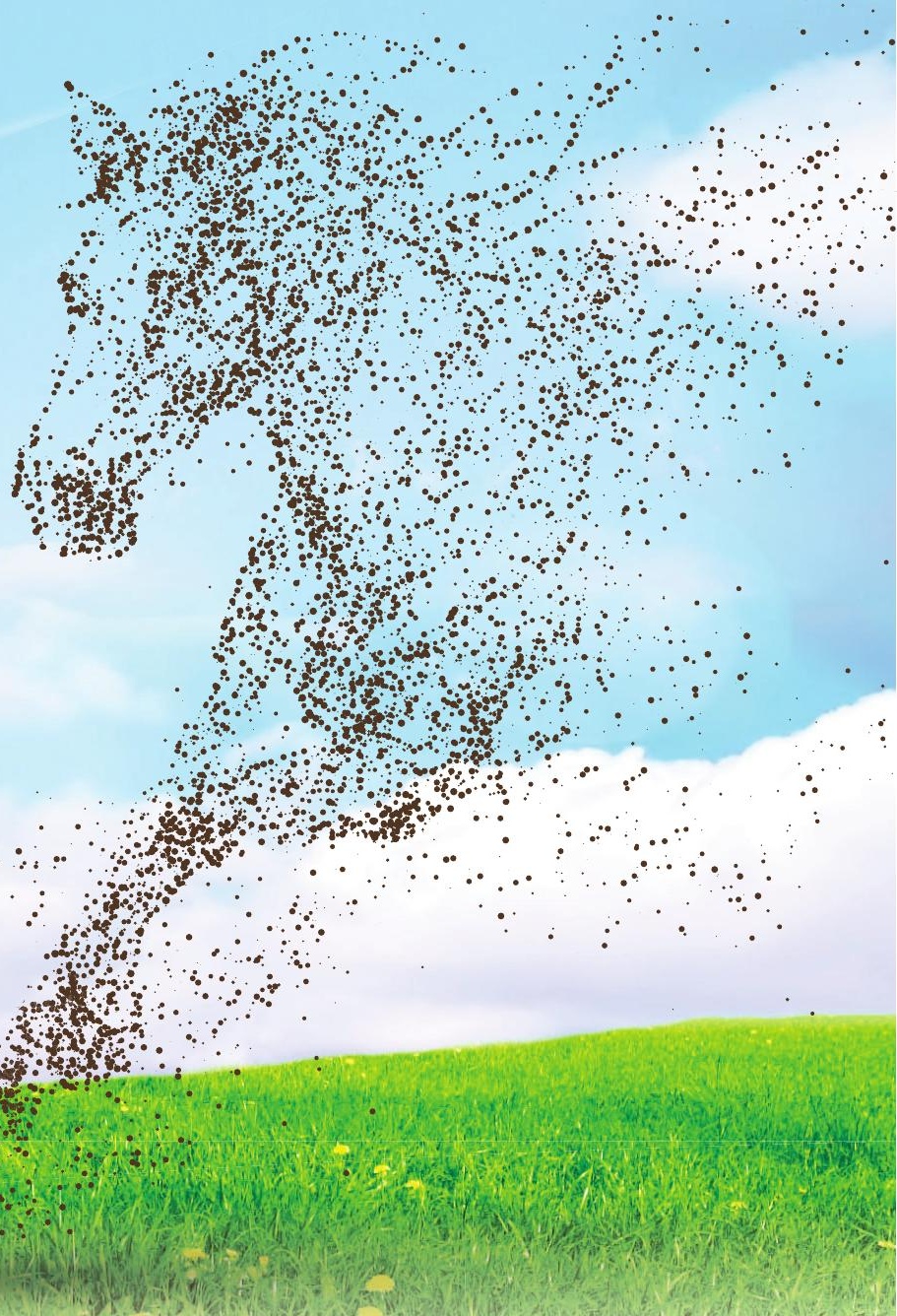

Denumirea comercială: Imesol comprimate filmate $30 \mathrm{mg}, 60 \mathrm{mg}, 90 \mathrm{mg}, 120 \mathrm{mg}$. Compozitie cantitativă si calitativă: fiecare comprimat filmat contine etoricoxib 30 mg, $60 \mathrm{mg}, 90 \mathrm{mg}$, respectiv $120 \mathrm{mg}$. Indicații terapeutice: Adolescenti cu vârsta de 16 ani și péste, pentru tratamentul simptomatic al artrozei (A), poliartritei reumatoide (PR), spondilitei anchilozante si al durerii si semnelor de inflamatie asociate cu artrita gutoasă acută. Doze si mod de administrare: Artroză - $30 \mathrm{mg}, 0$ dată pe zi,maxim 60 mg pe zi. Poliartrită reumatoidă - $60 \mathrm{mg} 0$ dată pe zi, maxim $90 \mathrm{mg} 0$ dată pe zi. Spondilită anchilozantă - $60 \mathrm{mg} 0$ dată pe zi,maxim 90 mg 0 dată pe zi. Afe्ccțiuni dureroase acute In afectiunile dureroase acute, etoricoxibul trebuie utilizat doar pentru perioada simptomatică acută. Artrita gutoasă acută - 120 mg 0 dată pe zi. In studiile clinice privind artrita gutoasă acută, etoricoxibul a fost administrat timp de 8 zile.Dureri după interventii chirurgicale dentare - 90 mg 0 dată pe zi, limitată la o perioadă maximă de 3 zile. Vârstnici - Nu este necesară 0 ajustare a dozelor la pacientii vârstnici. Pacienti cu insuficientă hepatică - insuficientă hepatică usoară (scor 5-6 în clasificarea Child-Pugh) maxim 60 mg o dată pe zi. La pacienții cu insuficiență hepatică moderată (scor 7-9 în clasificarea Child-Pugh), maxim 30 mg o dată pe zi. Pacienti cu insuficientă renalâ Nu este necesară 0 ajustare a dozei là pacientii cu un clearance al creatininei $\geq 30 \mathrm{ml} / \mathrm{min}$. Administrarea etoricoxibului la pacientii cu clearance al creatininei $<30 \mathrm{ml} / \mathrm{min}$ este contraindicată. Copii și adolescenti. Etoricoxibul este contraindicat la copii și adolescenti cu vârsta sub 16 ani. Mod de administrare - Imesol se administrează pe cale orală si poate fi luat cu sau fără alimente. Contraindicatii: Hipersensibilitate la substanta activă sau la oricare dintre excipienti. Ulcer gastro-duodenal activ sau hemoragie gastro-intestinală (Gl) activă. Pacienti care, în urma administrarii acidului acetilsalicilic sau a altor medicamente antiinflamatoare nesteroidiene (AlNS), inclusiv inhibitori de COX-2 (ciclooxigenază 2), au prezentat bronhospasm, rinită acută, polipi nazali, angioedem, urticarie sau reactii de tip alergic. Sarcină si alăptare. Insuficientă hepatică severă (albuminemie $<25 \mathrm{~g} / \mathrm{l}$ sau scor Child-Pugh $\geq 10$ ). Clearance renal al creatininei estimat $<30 \mathrm{ml} / \mathrm{min}$. Copii si adolescenti cu vârsta sub 16 ani. Boală intestinală inflamatorie. Insuficientă cardiacá congestivă (clasa II-IV NYHA). Pacienti cu hipertensiune arterială, la care tensiunea arterială este persistent crescută peste valoarea de 140/90 mmHg si nu este controlată adecvat. Diagnostic de boală cardiacă ischemică, boală arterială periferică si/sau boală cerebrală vasculară. Interactiuni cu alte medicamente si àlte forme de interacțiune: anticoagulante orale, Diuretice, inhibitori ai ECA și antagonoști ai réceptorilor angiotensinei II, acid acetilsalicilic, ciclosporină și tacrolimus, litiu, metotrexat, contraceptive orale, terapie de substitutie hormonală (TSH), digoxină. Sarcina si alăptarea: Nu sunt disponibile date clinice referitoare la tratamentul cu etoricoxib în timpul sarcinii, nu se cunoaste dacă etoricoxibul se excretă în laptele uman. Feméile tratate cu etoricoxib nu trebuie să alăpteze, asupra capacității de a conduce vehicule si de a folosi utilaje: Pacientii care prezintă ameteli, vertii sau somnolentă în timpul tratamentului cu etoricoxib nu trebuie să conducă vehicule sau să folosească utilaje. Reactiii adverse: foarte frecvente: durere abdominală. Supradozaj: In studiile clinice, administrarea de doze unice de etoricoxib de până la 500 mg și de doze repetate de până lả 150 mg pe zi, timp de 21 zile, nu a determinat efecte toxice semnificative. Detinătorul autorizatiei de punere pe piată: Terapia SA, Str. Fabricii nr. 124, Cluj-Napoca, România. Data primei autorizări sau a reînnoirii autorizației: lanuarie 2016. Datá revizuirii textului: Februarie 2019.

Acest material promotional este destinat profesionistilor din domeniul sănătătiti. Pentru informatiii complete de prescriere vă rugăm consultati rezumatul caracteristicilor produsului disponibil pe website-ul Agentiei Nationale a Medicamentului si Dispozitivelor Medicale http://www.anm.rol/. Informatii suplimentare se pot obtine la sediul reprezentantului local, Terapia SA, Str. Fabricii Nr. 124, Cluj--Napoca, tel:0264 501 500, fax: 0264415097 . Pentru raportarea reacțilior adverse vă rugăm să contactați reprezentanța locală a deținătorului autorizației de punere pe piață la tel: 0264501502.

\section{SC Terapia SA}




\section{ÎNCETINESTTE}

DEGRADAREA

ARTICULATIILOR

prin inducerea Toleranței Orale

\section{a)}

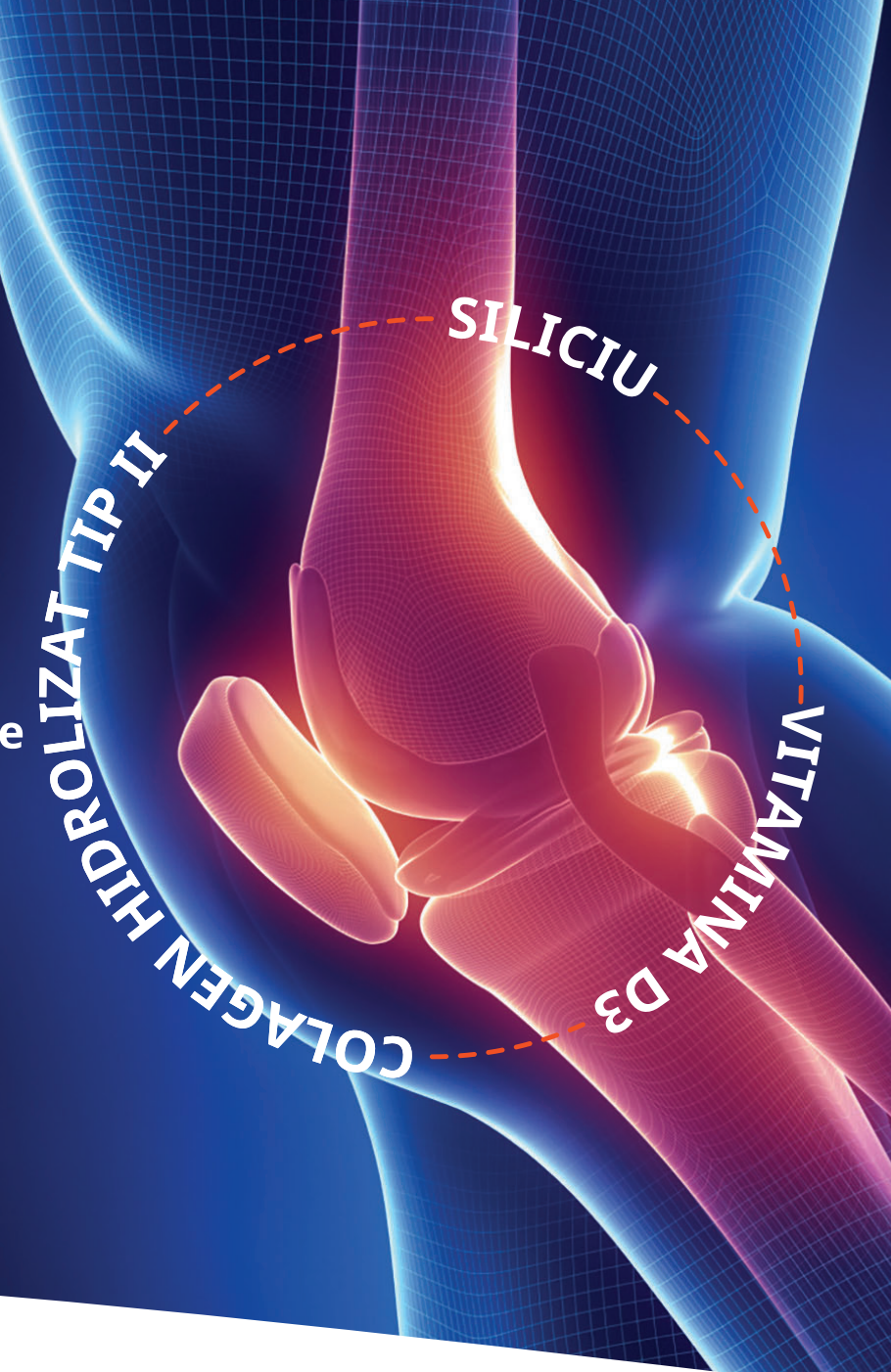

Bongen ${ }^{T M}$

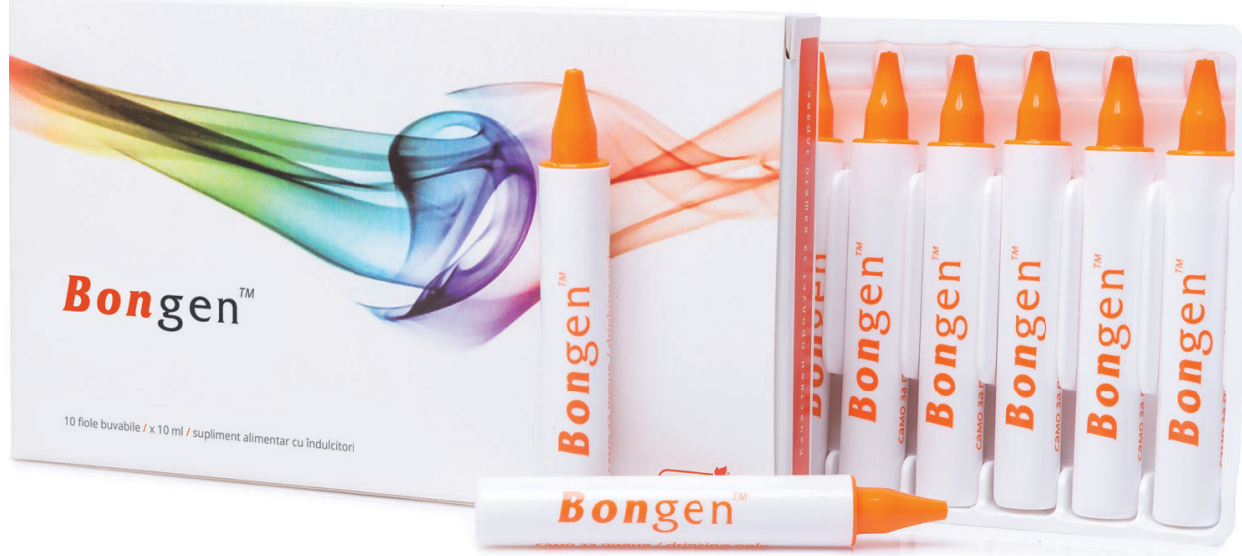




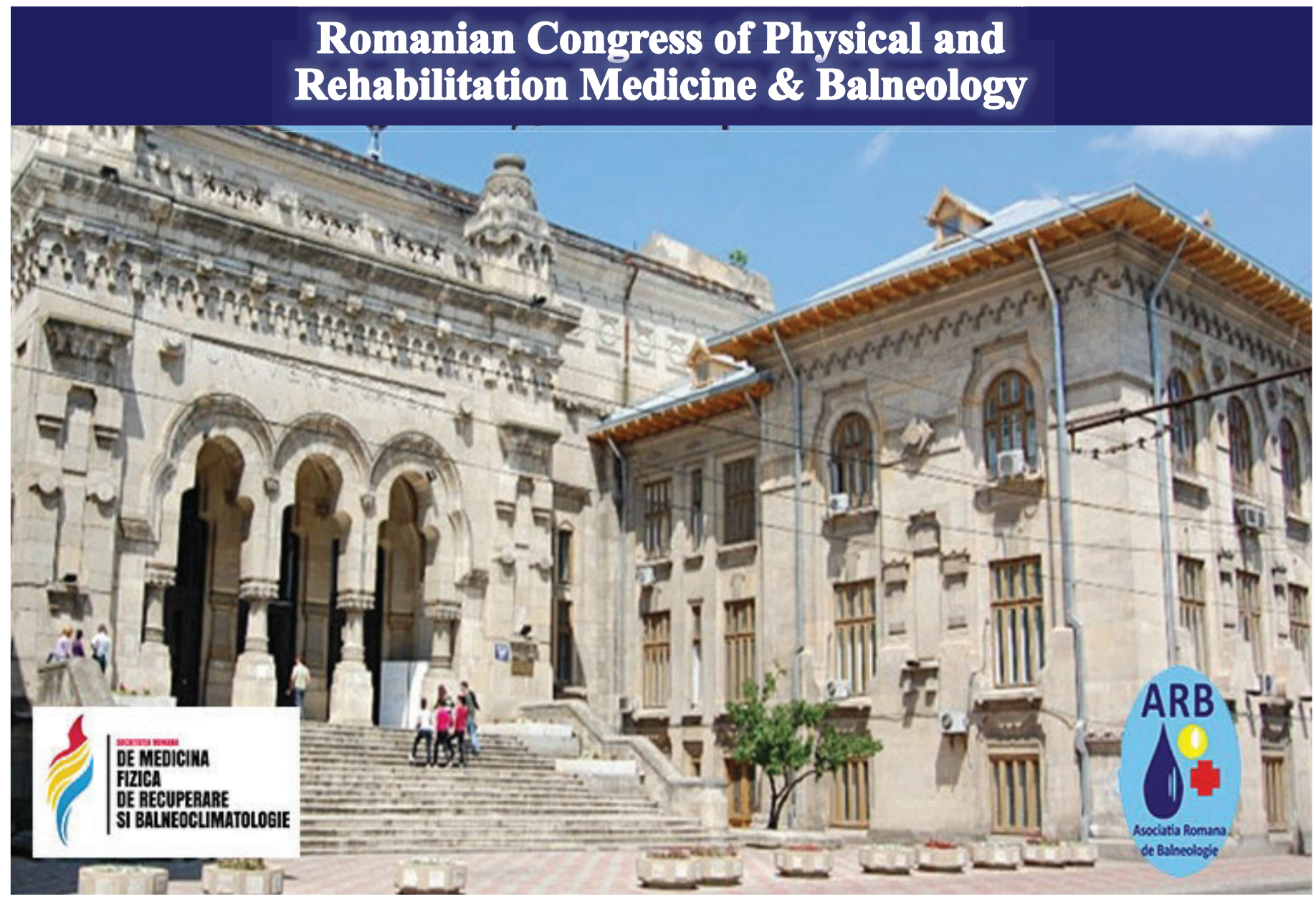

Manuscript Requested Quality:

- Correct page numbers and spelling in the document.

- Checking text and page numbers in table of contents.

- Checking and Ensuring tables, figures, references, etc. cited in text

- Checking lists, paragraphs, figures, etc., numbered or lettered consecutively.

- Ensuring that there are no duplicate tables and figure titles

- Checking hyperlinks to references.

- Reviewing sentences for spelling and grammatical mistakes.

- Checking style, size, and typeface for headings, titles, bullets etc.

- Checking of Insertion of appropriate page breaks

- Ensuring consistent justification for text, callouts, cautions, warnings etc.

- Choosing correct size and layout of pages.

- Ensuring consistent use of capitalization and spelling.

- Applying proper numbering mechanics in the article.

- Checking format for bibliographic references, i.e. according to any of Citation Style.

- Using punctuation consistently. 


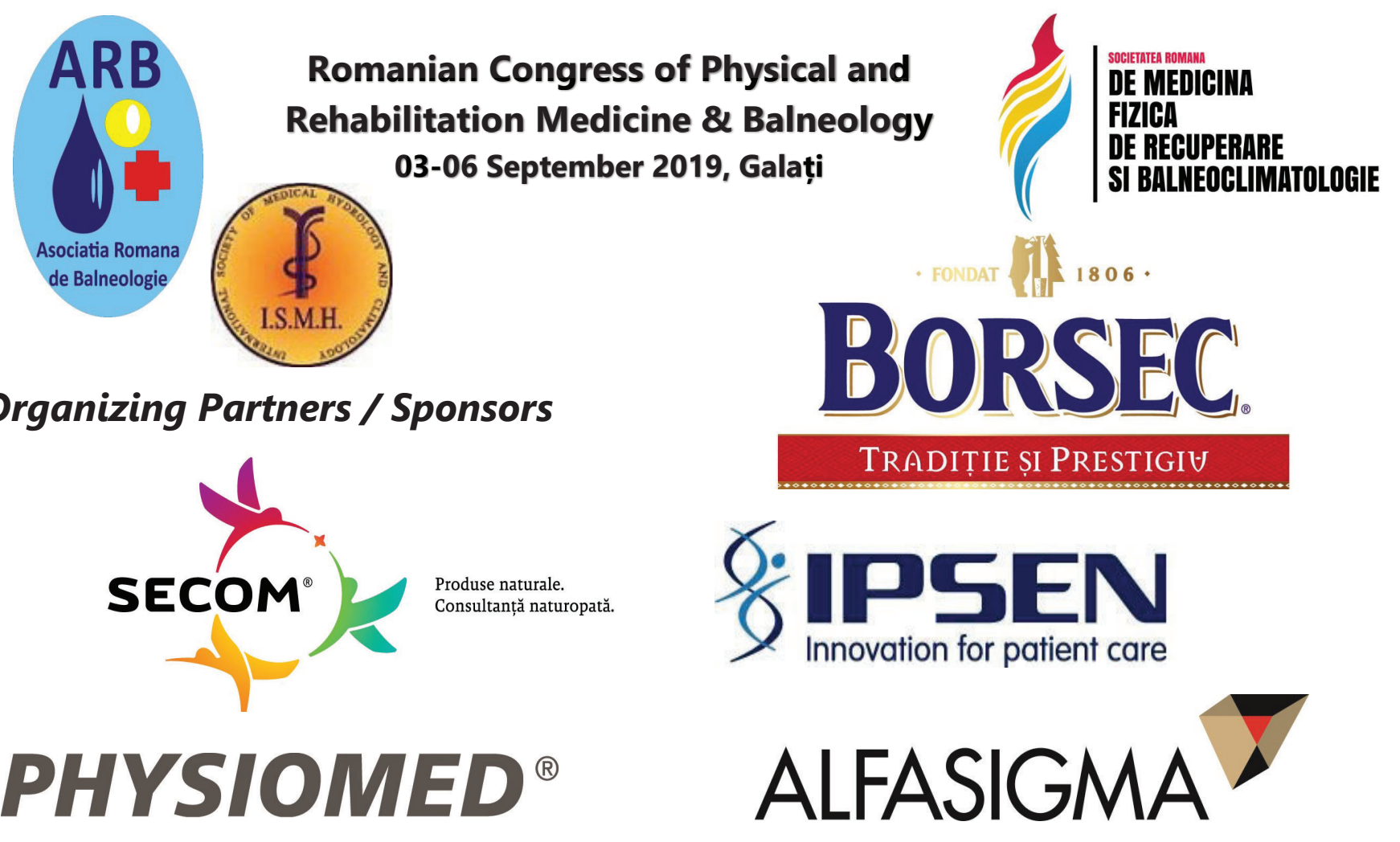

TECHNOLOGY FOR THERAPY

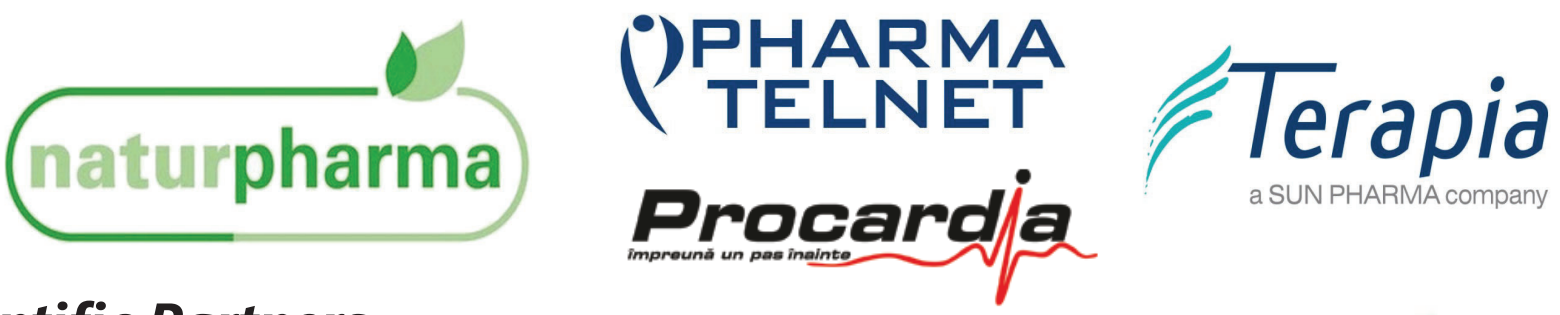

\section{Scientific Partners}
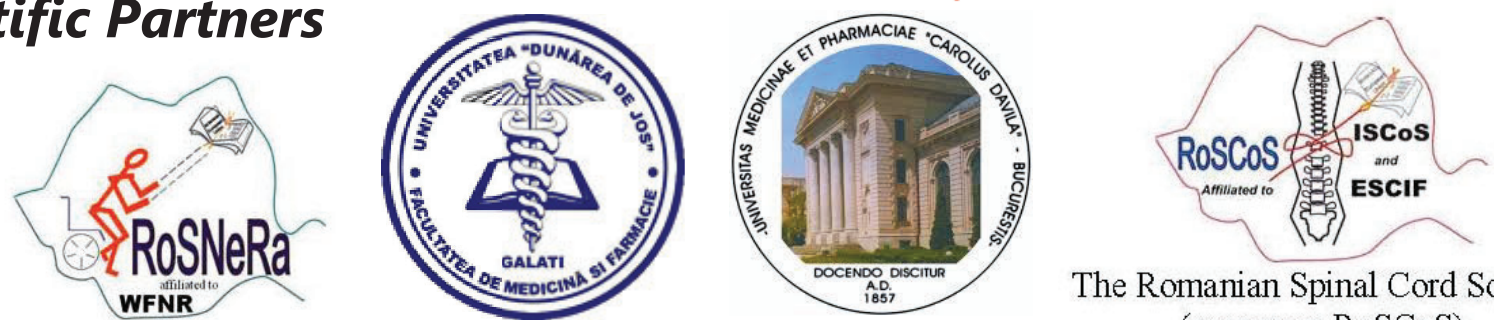

The Romanian Spinal Cord Society (acronym: RoSCoS)

The Romanian Society for NeuroRehabilitation (acronym: RoSNeRa)

III

UNIVERSITATEA DE MEDICINĂ ȘI FARMACIE

GRIGORE T. POPA IASTI
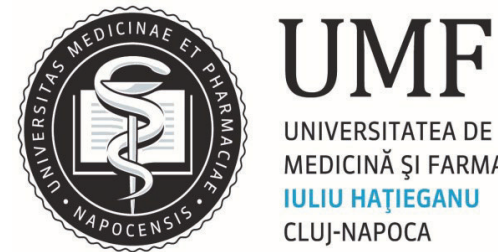

UNIVERSITATEA DE MEDICINĂ ŞI FARMACIE IULIU HAŢIEGANU CLUJ-NAPOCA
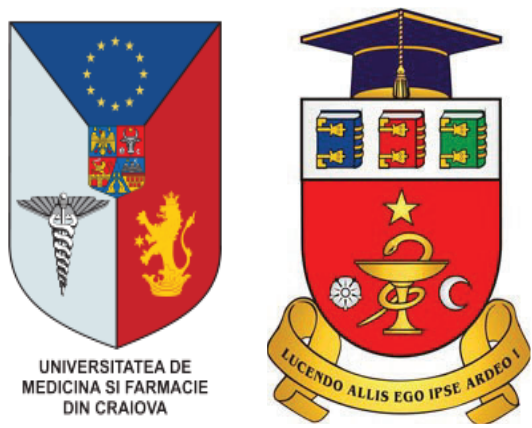

R O M Â N I A

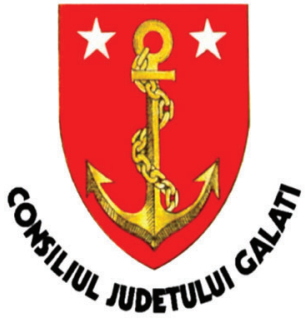

\section{Media Partners:}

BALNEO
BALNEO RESEARCH JOURNAL Englislı Eidition eISSN 2069-7619 pISSN 2069-7597
ROMANIAN ASSOCIATION OF BALANEOLOGY 